\title{
Sobre as circunstâncias em que transcorreu a infância de jovens que moraram nas ruas do município de São Paulo e os possíveis efeitos sobre suas personalidades.
}

RUBENS DE AGUIAR MACIEL

Dissertação apresentada ao

Programa de Pós-Graduação em Saúde Pública da Faculdade de Saúde Pública da Universidade de São Paulo para a obtenção do título de Mestre em Saúde Pública.

Área de Concentração: Saúde Materno-Infantil. Orientador: Prof. Dr. Cornélio P Rosenburg.

São Paulo

2005 
Autorizo, exclusivamente para fins acadêmicos e científicos, a reprodução total ou parcial desta dissertação, por processos fotocopiadores. Ao usá-la cite a fonte.

Assinatura:

Data: 
O inconsciente pode ser um estorvo para quem gosta de tudo simples e arrumado, mas, decididamente, não pode ser ignorado por planejadores e pensadores.

(WINNICOTT 2002). 


\section{DEDI CATÓRI A}

A meus pais, Jahir e Antonietta, porque sem eles este trabalho não seria possível. Esta é uma expressão de minha gratidão por tudo o que deles recebi na vida.

Às minhas filhas, Daniele e Manuela, que tantas alegrias e orgulho me proporcionaram.

A todos aqueles que se dedicam arte de compreender a mente, aliviar o sofrimento psíquico e ajudar no desenvolvimento humano. 


\section{AGRADECIMENTOS}

Ao meu orientador Professor Rosenburg que com sua visão de mundo, sua sensibilidade e seus interesses humanitários me apontou caminhos novos e me acompanhou no meu re-apreender a ver e a caminhar rumo a novos horizontes; aos componentes da banca doutora Aparecida Magali de Souza Alvarez e professor Alberto Advíncula Reis, às professoras do departamento de Saúde Materno-Infantil, Fumika Peres, Keiko Ogura (em memória) e Néia Schor, pelo interesse e incentivo fornecidos para que realizássemos esse trabalho; à Dra. Amélia Thereza de Moura Vasconcellos que com seus vastos e profundos conhecimentos, sua generosidade e sua vocação para o ensino é co-responsável por grande parte deste trabalho; aos professores do IPPIA (Instituto de Psiquiatria e Psicoterapia da Infância e Adolescência), Grazieta B M Peterle, Dr. Ésio dos Reis Filho e ao Dr. Nélio W. Sacramento por suas colaborações e sugestões; à Dra. Kimy Otsuka Stasevskas por sua valiosa revisão e às suas enriquecedoras, profundas e poéticas concepções sobre o ser humano; à Suely Gevertz, ao Dr. Hoel Sette Junior e ao Dr. Jorge Farran, que com grande competência e humanidade me orientaram quanto aos cuidados com minha saúde; à meus parentes Alcântara Farran e Neide Aguiar pela compreensão e apoio que me forneceram; à Dra. Vanessa de Almeida Silva, amiga que me deu o conforto de sua companhia nesta jornada solitária; à amiga Ana Lucia Nano Barbieri, pelas incontáveis e incansáveis revisões e valiosas sugestões que ajudaram na composição deste trabalho; à Leila Ali, amizade que atravessou os tempos; à Iara Macedo, Leandro Cleto e Sonia Heto pelas contribuições tão atenciosamente executadas durante estes anos de preparação e realização desta dissertação. Ao CNPq (Conselho Nacional de Pesquisas), pela bolsa de estudos concedida. 


\section{RESUMO}

Maciel RA. Sobre as circunstâncias em que transcorreu a infância de jovens que moraram nas ruas do município de São Paulo e os possíveis efeitos sobre suas personalidades. São Paulo; 2005. [Dissertação de mestrado - Faculdade de Saúde Pública da USP].

Buscou-se descrever e compreender as principais dimensões da personalidade de cinco jovens, entre 15 e 19 anos de idade, que viveram nas ruas do município de São Paulo, e que estavam abrigados em instituições. Mediante depoimentos pessoais, procurou-se resgatar, retrospectivamente, as circunstâncias de vida presentes no desenvolvimento desses jovens. Partimos da hipótese de que as condições emocionais de existência nos primeiros anos de vida relacionam-se, de forma estreita, com o desenvolvimento da personalidade e do caráter desses jovens. Adotou-se o método qualitativo, tendo, como referencial teórico, o conjunto de conceitos e hipóteses da teoria psicanalítica. Para a coleta de dados, foram utilizadas entrevistas semi-estruturadas, além de desenhos livres e testes projetivos. Constatamos que em épocas precoces da maturação dos jovens entrevistados (fase do "Cordão Umbilical Afetivo"), suas famílias passaram circunstâncias potencialmente adversas (Potencial Circunstancial) para a estabilidade emocional dos seus componentes e das suas relações interpessoais, circunstâncias essas que parecem ter afetado o desenvolvimento emocional de nossos sujeitos. Não obstante, estes jovens, puderam também vivenciar circunstâncias favorecedoras, internalizadas como experiências positivas que possibilitaram que o impulso para a integração e desenvolvimento pessoal também se estabelecesse em suas personalidades. Concluímos este trabalho esperando que uma visão mais abrangente e integrada da saúde e da doença no homem seja um dos objetivos das instituições de ensino na formação de seus profissionais, assim como esperamos que os responsáveis pelas políticas de saúde, contemplem a Saúde Mental sob a perspectiva de prevenção, adotada e exposta por esse trabalho, ressaltando a importância dos conceitos de "Cordão Umbilical Afetivo" e "Potencial Circunstancial” para a Saúde Pública.

Descritores: Crianças e jovens em situação de rua, psicanálise, Potencial Circunstancial, Cordão Umbilical Afetivo, personalidade e caráter, prevenção em saúde mental, relação mãe-bebê. 


\section{SUMARY}

MACIEL RA. . Sobre as circunstâncias em que transcorreu a infância de jovens que moraram nas ruas do município de São Paulo e os possíveis efeitos sobre suas personalidades. [On the circumstances in which the childhood of teenagers who had been street children in the city of São Paulo took place and the possible effect on their personalities] São Paulo (Br); 2005.

[Mestrado - Faculdade de Saúde Pública da Universidade de São Paulo Brasil].

We tried to understand and describe the main personality dimensions of five teenagers, of ages between 15 and 19 years old, who lived in the streets of the city of São Paulo, and who were living in shelters. Based on their personal accounts, we tried to retrospectively recover the life circumstances during their development. We started from the hypothesis that the emotional conditions of existence in the first years of life relate, in a close way, to personality development and to the character of these teenagers. We applied the qualitative method, having, as a theoretical reference, the fundamentals of psychoanalytical theory. To collect the data, we used semi-structured interviews, free drawings and projective tests. We found out that the families of our subjects have been through more than one period of potentially adverse circumstances (circumstantial potential) that influenced the emotional stability of their members and their personal relationships. These circumstances ocurred in the early maturation stages of these teenagers ("emotional umbilical cord" stage). On the other hand, these teenagers could also known some favourable circumstances, internalized as positive experiences, which provided the will for integration and personal development in their personalities. We conclude hoping that a wider and more integrated vision of health and disease be one of the goals of teaching institutions in worker formation, as well as hoping that those responsible for public policies regard mental health from the prevention perspective, adopted and explained by this work, noting the importance of the "emotional umbilical cord" and "circumstantial potential" concepts for public health.

Descriptors: street children, psychoanalysis, Circumstantial Potential, Emotional Umbilical Cord, personality and character, prevention in mental health, motherbaby relationship. 


\section{ÍNDICE}

1. INTRODUÇÃO 1

1.1 A evolução da concepção de sujeito.

$\begin{array}{ll}1.2 \text { Personalidade e caráter } & 12\end{array}$

1.3 As contribuições de Melanie Klein $\quad 27$

1.4 Cordão Umbilical afetivo $\quad 31$

$\begin{array}{ll}1.5 \text { Normalidade e enfermidade } & 37\end{array}$

2. OBJETIVOS 41

2.1 Objetivo geral 41

2.2 Objetivo específico $\quad 41$

2.3 Hipótese de trabalho $\quad 41$

3. MÉTODO 42

3.1 Modelo teórico $\quad 42$

3.2 População de estudo 44

3.3 Instrumentos e procedimentos metodológicos 46

3.3.1 Depoimento pessoal $\quad 46$

3.3.2 Símbolos de um heredograma 47

3.4 Instrumentos de pesquisa projetiva 48

3.4.1 Entrevista dirigida 48

3.4.2 Desenho livre e o HTP 49

3.4.3 TAT $\quad 50$

3.4.4 Considerações éticas $\quad 51$

4. RESULTADOS e IINTERPRETAÇÕES 52

$\begin{array}{ll}\text { 5. CONSIDERAÇÕES FINAIS } & 117\end{array}$

$\begin{array}{ll}\text { 6. REFERÊNCIAS } & 124\end{array}$

7. ANEXOS EM CD-ROOM.
1. Aprovação do comitê de Ética

2. Material do sujeito C.f. $\quad$ A2

2. Material do sujeito E.m $\quad$ A3

3. Material do sujeito F.m . A4

4. Material do sujeito P.f. $\quad$ A5

5. Material do sujeito P.m. A6 


\title{
1 I NTRODUCÃO
}

Dentre as motivações para escolha deste tema de investigação, uma delas, da ordem do afetivo, é o interesse pelo desenvolvimento da personalidade do ser humano, que está bem expressa nas palavras de FRANÇOISE DOLTO (1980: 151):

\begin{abstract}
A simpatia humana pelos que sofrem, que está na base da escolha da carreira médica, é uma sublimação que deriva diretamente da inquietação diante de nosso próprio sofrimento, inconscientemente sentido no decurso do nosso desenvolvimento, se formos dotados de uma sensibilidade que nos torna mais vulneráveis que os outros. Entre os meios de defesa empregados em face desse sofrimento, um deles e o de maior êxito é o interesse em aliviar o sofrimento alheio.
\end{abstract}

$E$, dentre os que sofrem, é bastante expressivo o contingente de jovens que vivem nas ruas em situação de risco, justificando o interesse de setores da sociedade como a Igreja e os Órgãos de Segurança, de inúmeras instituições como as ONGs (Organizações não Governamentais), e também de áreas como Serviço Social, Psicologia, Direito da Criança e do Adolescente entre outras. Nos últimos anos, algumas instituições de ensino, como o CEPRua (Centro de Estudos Psicológicos sobre Meninos e Meninas de Rua), vinculado à Universidade Federal do Rio Grande do Sul, vêm desenvolvendo pesquisas sobre crianças, adolescentes e famílias em situação de risco social e pessoal, enfatizando aspectos psicológicos do desenvolvimento e a promoção de saúde. Em São Paulo, o Projeto Quixote, ligado ao Departamento de Psiquiatria, da UNIFESP (Universidade Federal de São Paulo) e mantido pela Secretaria de Assistência e Desenvolvimento Social do Estado de São Paulo e Secretaria Municipal da Saúde, entre outros, explicita, entre seus objetivos "construir uma infância e adolescência plena e cidadã junto a meninos e meninas em situação de risco social" (PROJETO QUIXOTE 2004: página on-line).

Segundo RIGATO (2002), a economia mundial não está resolvendo o problema da pobreza, da falta de acesso à saúde, à educação, ao saneamento básico, aos bens de consumo e à dignidade para um imenso contingente de indivíduos na 
maior parte dos países em desenvolvimento. Essa condição de escassez de recursos afeta, principalmente, os mais jovens, que necessitam de condições adequadas para desenvolver-se satisfatoriamente.

Baseada em dados recolhidos no Relatório da Situação Mundial da Infância, publicado em 2001, pela UNICEF, RIGATO (2002:12) relata que a distribuição de renda no Brasil é de imensa desigualdade, apenas $8 \%$ da renda é distribuída entre $40 \%$ da população, enquanto que $64 \%$ de nossas riquezas está nas mãos de $20 \%$ da população considerada rica. Informa, ainda, que, de acordo com o Instituto Brasileiro de Geografia e Estatística (IBGE), vivem com meio salário mínimo 30\% das famílias brasileiras com crianças de 0 a 6 anos de idade. Baseada no relatório da UNICEF, a autora informa: "Além da concentração de riqueza, existe a concentração de terras, com um por cento da população sendo proprietária de $43 \%$ de todas as terras". (RIGATO 2002:12)

Os números sobre essa população são difíceis de serem encontrados e por vezes temos de nos contentar com informações desatualizadas.

No censo demográfico de 1996, realizado pelo IBGE, o município de São Paulo totalizava 9.839.436 habitantes, com 33,66\% dessa população na faixa etária da infância e adolescência, segmento mais duramente atingido pela desigualdade social, em função de sua vulnerabilidade (RIGATO 2002:13). A autora aponta que, segundo pesquisa realizada em 1995, pelo Instituto de Pesquisa Econômica Aplicada (IPEA), 204.022 famílias, com crianças e adolescentes, viviam em situação de indigência.

De acordo com a autora (p.16), a expressão "meninos de rua" foi criada na década de 80, para "designar crianças e adolescentes que passam parte considerável de suas vidas sobrevivendo nas ruas das grandes cidades", embora essa forma de viver já tenha sido registrada desde o final do século XIX, com o nome de "meninos abandonados".

Segundo o senso comum, o menino de rua é todo aquele que está nas ruas, vestido de forma miserável e simbolizando o descaso social. Apesar disso, a população de crianças e adolescentes que estão nas ruas não é homogênea. Os termos "meninos de rua" e "meninos na rua" tem sido utilizados para distinguir as crianças que realmente moram nas ruas das que não moram. Os meninos "na" rua ainda têm contato com suas famílias, freqüentam a escola e a maioria retorna para casa no fim do dia. As crianças de rua abandonaram ou 
foram abandonadas por suas famílias, escolas e comunidade onde moravam e foram levadas para uma vida nômade nas ruas (RIGATO 2002: 16-7).

Atualmente fala-se em crianças e jovens em situação de rua ${ }^{1}$.

Para ROSA (1999:03): “a prevalência do discurso social para estas crianças vem ancorado no apagamento do discurso familiar".

O processo de afastamento da família é gradativo, com espaços de tempo cada vez maiores, até uma total inserção no mundo das ruas e uma exposição cada vez maior aos riscos desse modo de vida. Nesse contexto, risco indica uma situação de vulnerabilidade e perigo de vida. Crianças "de" rua correm mais riscos do que crianças "na" rua, com maior probabilidade de se envolverem com o crime, com as drogas, e engajarem-se em atividades sexuais precocemente. Apoiando-se em Reppold CT, Pacheco J. Bardagi M e Hutz CS (2002), RIGATO (2002: 18) define: “Uma criança será considerada em situação de risco quando seu desenvolvimento não ocorrer conforme o esperado para sua faixa etária e para os parâmetros de sua cultura".

Gutiérrez e colaboradores, citados por MEJIA-SOTO G, REA CATAÑEDA R, ANAYA GONZALEZ M, GORAB RAMIREZ A, SUMANO AVENDANO E (1998: 175), ao realizarem uma investigação sobre as relações sociais dos meninos de rua, chegam à conclusão que "eles não ficam tão desamparados e desprotegidos como se pensa. Na rua estabelecem relações sociais entre eles e com outras pessoas, ocorre amizade, proteção, confiança, auto-organização, afeto e solidariedade".

De acordo com o relatório da UNICEF, anteriormente citado, estima-se que o Brasil possua 7,4 milhões de crianças trabalhadoras (meninos na rua) e 8 milhões de meninos de rua.

$\mathrm{Na}$ contagem feita pela Secretaria da Criança, Família e Bem Estar Social do Estado de São Paulo, em 1993, foram encontrados no município de São Paulo 4520 crianças e adolescentes no horário diurno e 895 no horário noturno. Dos $4520,81 \%$ eram meninos e $18 \%$ meninas (não foi identificado o sexo de um\%). Como o roteiro abrangia basicamente as ruas, não foram contemplados os meninos que, nesse horário,

\footnotetext{
${ }^{1}$ De acordo com informação fornecida pelo Prof. Dr. Rubens Adorno, docente da Faculdade de Saúde Pública da Universidade de São Paulo.
} 
estavam participando de atividades em instituições, o que pode ter subestimado o montante de meninos (RIGATO 2002:20).

O Censo dos Moradores de rua, realizado pela parceria FIPE/SAS, no ano de 2.000, constatou que os locais de maior concentração dessa população, no município de São Paulo, são os distritos da Sé, República e Santa Cecília.

Ao procurar entender o processo de produção da problemática em questão, a UNICEF, em seu relatório Children in especially difficult circumstances, de 1986, refere: "Várias teorias já foram elaboradas, algumas relacionando a existência de crianças de rua com o regime capitalista não ditatorial de países em desenvolvimento; com a predominância da descendência indígena ou africana entre a população; com a aculturação indígena; com os movimentos nacionais anti-coloniais etc" (RIGATO 2002: 21).

A autora considera que, ao lado disso, "fatores como condição psicológica da criança e de sua família, percepção da vida na rua e o grau de uma existência de uma cultura de rua, deverão ser considerados" ( $p$ 21). E também: "O estudo de Minayo contribuiu para essa compreensão e destacou algumas forças de caráter expulsivo, como conflitos familiares, violência corporal e circulação de crianças" $(p 22)$.

Nesse sentido, assinala que a fragmentação das famílias extensas e a falta do suporte comunitário; freqüentes mudanças de bairro e de escola; a interrupção dos estudos, desmontam uma estrutura protetora. "A gradual permanência na rua torna mais frágeis para o menino os laços entre esses elementos, fomentando um desinteresse pelo procedimento escolar formal" (....). "A rua desponta como local ideal para o exercício de estratégias de sobrevivência, oferecendo inúmeras oportunidades de ganhar a vida e sendo, também, um espaço de vivência significativo, com muitos aspectos lúdicos que permitem a realização de fantasias infantis" (RIGATO 2002: 23). Citando Gregori MF (2000), ela declara: "Importante destacar é o fato de os meninos "na" rua estarem sempre circulando, seja por instituições, seja pelo ir e vir entre suas casas e a rua, seja ainda pelos vários locais na rua que fixam como referência".

WINNICOTT (1983: 186) escreve que as motivações da sociedade para enfrentar o problema da tendência anti-social de um indivíduo, são:

1. Vingança; 
2. Desejo de socializar o indivíduo;

3. Compreensão e aplicação da compreensão à prevenção.

Diante do exposto, buscamos, dentre os elementos citados, investigar a constituição psicológica de adolescentes que não vivem com suas famílias, seu comportamento individual e em sociedade. Para tanto, apresentamos alguns conceitos básicos que utilizamos no presente estudo, recorrendo a autores que selecionamos como interlocutores para o desenvolvimento do mesmo.

\subsection{A evolução da concepção de sujeito}

As concepções sobre o homem e sua constituição psicológica sempre foram tema de grande interesse desde os séculos mais remotos, e sofreram, como continuam sofrendo, constantes evoluções e novas concepções. Segundo GHIRALDELLI J r, em As concepções da Infância (1992: artigo on-line):

(....) Há um grupo que acredita na idéia da infância como sendo um período prolongado, que se caracteriza principalmente pela inocência. Contestando este, há um outro grupo que defende a idéia de que a infância, sendo, ou não, um período longo, pode ser pensado como possuindo uma série de características, mas nunca as de inocência e bondade como essenciais. O primeiro grupo, pode-se assim dizer, é o herdeiro de um movimento específico na história do pensamento no ocidente, a saber, a ruptura proporcionada por Rousseau em relação às concepções sobre a infância vindas de Santo Agostinho e de Descartes. Como se sabe, Santo Agostinho viu a criança imersa no pecado, na medida em que, não possuindo a linguagem ('infante': o que não fala - portanto, aquele que não possui logos), mostrar-se-ia desprovida de razão, exatamente o que seria o reflexo da condição divina em nós, os adultos. Descartes viu a criança como alguém que vive uma época do predomínio da imaginação, dos sentidos e sensações sobre a razão, e mais, uma época da aceitação acrítica das tradições, postas pelos preceptores - tudo o que macularia nosso pensamento, conduzindo-nos mais tarde, uma vez adultos, à dificuldade no uso da razão e, portanto, ao erro. Para os dois, Agostinho e Descartes, quanto mais cedo saíssemos da condição de criança, melhor para nós.

Rousseau rompeu com a visão agostiniana e cartesiana na medida em que colocou o erro, a mentira e a corrupção como sendo frutos da incapacidade de julgar 
de quem não pode mais beneficiar-se, nos seus julgamentos, do crivo de um "coração sincero" e puro, próprio da condição infantil, o protótipo da condição do "bom selvagem".

Há pelo menos duzentos anos, desde Hegel, uma boa parte dos ocidentais começou a falar sobre as coisas do mundo de um modo diferente, considerando-as menos como situações e elementos dados e imutáveis, "naturais" (no sentido essencialista do termo), mas como situações e elementos historicamente construídos. Assim, começamos a esboçar uma terceira via para conversarmos sobre as crianças.

KRUTZEN (2002: artigo on-line), citando Ariès, acrescenta que o conceito de infância, como um período especial da vida da criança em que ela merece ser protegida e preservada dos perigos do meio, data do século XVII. O que tínhamos antes, na Idade Média, eram relações de dependência dentro de um regime feudal. “(....) o termo família referia-se à fidelidade dos servos a um senhor, sem nenhuma conotação sentimental ou natural". Era uma época em que encontrávamos crianças pequenas vestidas como adultos em miniatura, e raramente retratados ao lado de seus pais.

No século seguinte, embora já encontremos o início de um reconhecimento da especificidade desse período (infância), ainda havia crianças cumprindo jornadas de trabalho de até 16 horas diárias nas indústrias têxteis da Inglaterra. Graças aos esforços de alguns humanistas, iniciou-se um movimento, que passou a defender os infantes das condições de vida semelhantes às dos adultos. $O$ reconhecimento de que esse período de vida necessita de cuidados especiais conduz a uma nova forma de relação entre crianças e adultos, estabelecendose um período de cuidados peculiares para o desenvolvimento desses seres.

No século XIX, os cuidados com as crianças começam a ser cada vez mais valorizados, surgindo uma preocupação com a higiene geral para a prevenção de doenças, o aperfeiçoamento da dieta e oferecimento de cuidados pré-natais.

Para ROSEN (1994: 271): “Não é difícil encontrar as razões dessa preocupação: motivações políticas, econômicas e humanitárias convergiam para tentar reduzir o grande desperdício de vidas de crianças".

A repugnância diante do sofrimento humano tornou-se mais um elemento pela luta por programas de reforma. Em vários países, em maior ou menor grau, houve um afastamento dos princípios da livre competição, do liberalismo; passou-se a defender a necessidade da interferência do Estado para enfrentar os desajustes sociais. 
ROSEN (1994) relata que na segunda metade do séc. XIX, na França, um clínico chamado Caron concebeu a idéia de um ramo especial da higiene, relacionado com os bebês e as crianças sadias. Nasceu, assim, a Puericultura. Com os avanços nos conhecimentos sobre a saúde da criança, além da Puericultura, desenvolve-se a Pediatria e com elas, a importância da mãe é grandemente incrementada, assumindo o papel de cuidadora e educadora dos filhos, que antes ficavam com escravas, amas de leite ou babás. Desenvolve-se o saber "materno-infantil".

Sobre o cenário familiar, durante a passagem entre os séculos XIX e XX, JURANDIR FREIRE COSTA (1979:86-7) relata:

\begin{abstract}
A família dominada pelo sentimento de privacidade distingue-se da família antiga em vários sentidos. Em primeiro lugar, pais e filhos começam a valorizar o convívio íntimo e exclusivo entre eles, abandonado a companhia contínua de elementos estranhos, porventura residentes na casa. Em segundo lugar, os pais passam a ter maior interesse pelo desenvolvimento físicosentimental dos filhos, educando-os de maneira mais individualizada e levando-os, em conseqüência, a ganhar maior consciência de suas próprias individualidades. Em terceiro lugar, o amor entre pais e filhos torna-se a energia moral responsável pela coesão familiar, substituindo progressivamente a ética religiosa e os imperativos de sobrevivência material.
\end{abstract}

No século XX, pensadores de várias áreas do conhecimento - sociologia, filosofia, antropologia, medicina, psicologia e outros - alcançam patamares mais elevados de abstração nas investigações sobre a constituição do homem e da sociedade.

Em meados do século XX, NORBERT ELIAS (1994), com formação interdisciplinar, apresenta uma concepção sobre a interação entre o homem e a sociedade. O autor considera o homem como um ser constituído de um nós e a família, como a célula inicial, em que o processo de constituição psicológica e cultural do ser humano tem seu início. O autor questiona os segmentos que, dentro da psicologia, procuram estudar o homem isoladamente e que procuram esclarecer a sua estrutura psicológica, independente de suas relações com as outras pessoas, como também, correntes da psicologia social ou de massa, que não conferem nenhum lugar apropriado às funções psicológicas do indivíduo singular. Para ele, não há dúvida de que o homem é criado por outros que 
existiam antes dele. Esse indivíduo irá desenvolver-se dentro de uma família, que contém um passado que está presente em cada um de seus membros, e esta individualidade de cada membro familiar irá, em parte, contribuir na constituição psicológica desse sujeito.

ELIAS lembra que cada indivíduo ocupa um lugar na ordem geral das coisas, uma profissão, uma escolaridade, um status social, costumes relativos à época em que vive e, que para qualquer indivíduo, é impossível decidir que, de uma hora para outra, irá deixar de ser mercador de peixes e tornar-se um músico, ou mudar de classe social.

O mito da criação, que surge na Bíblia, sob a forma de Adão como o "pai originário", ainda se reflete, de forma mais ou menos consciente no imaginário de muitas pessoas. "É como se as pessoas crescidas, ao pensarem em suas origens, perdessem, involuntariamente, de vista o fato de elas mesmas, assim como todos os adultos, terem vindo ao mundo como crianças pequenas. Vez por outra, nos mitos científicos da origem, tal como nos religiosos, elas se sentem compelidas a imaginar: no começo, houve um único ser humano, que era um adulto" (NORBERT ELIAS 1994: 26).

Apesar das diferenças individuais inatas, prossegue o autor, é dentro do contexto social em que a criança vive, que ela se tornará um ser mais complexo e individualizado. A complexidade da sociedade em que o individuo cresce relaciona-se com as possibilidades de individuação. I solado das relações sociais, o indivíduo pode crescer fisicamente, mas , em sua composição psicológica, permanece semelhante a uma criança pequena" (1994:27).

O indivíduo inicia seu processo de desenvolvimento dentro de sua família, a menor célula do corpo social. Ele precisa dos adultos, para apreender a dominar seus impulsos, educar-se e aprender a viver em sociedade.

O autor compara o desenvolvimento humano com a tecedura de um tapete, em que aos fios iniciais básicos, as características inatas, vão se somando vários outros, em um entrelaçamento, que vai dando uma nova forma ao conjunto, dando origem a algo novo, que vai se criando, à medida que novos fios, com novas cores e novas tramas vão se acrescentando. 
Um ponto de vista semelhante é o do filósofo Ortega y Gasset. O conceito de Circunstância, formulado por ele, considera que o sujeito é o produto das circunstâncias que ele vive: "Eu sou eu e minha circunstância" (KUJAWSKI 1994:38-9), isto é, o indivíduo é resultado dos inúmeros fatores que, em conjunto, moldam aquele homem em particular, desde as circunstancias mais gerais, como: seu momento histórico e cultural; o país que habita com suas condições/perspectivas econômicas, sociais e culturais, assim como as condições geográficas e climáticas - como também as mais específicas, como: sua família; sua saúde; os insumos materiais disponíveis para seu desenvolvimento; os amigos; as doenças; as mudanças; as perdas que ocorrem em sua vida; suas crenças; espiritualidade; valores sociais etc..

Nosso contato, na condição de aluno, com o professor ROSENBURG levou-nos a um esforço introspectivo e questionador, buscando trabalhar no sentido de buscar uma visão mais abrangente na compreensão dos fenômenos humanos e da vida, em geral. Esta visão de ROSENBURG coincide, em vários aspectos, com as concepções de ELIAS e de Ortega y Gasset, acima relatadas. Ele denomina de Potencial Circunstancial ${ }^{2}$ a esse ponto vista, que privilegia para pensar os fenômenos e, em especial, os fenômenos humanos.

Nesse sentido, é importante contextualizar o homem contemporâneo, que vive transformações significativas nas áreas biológica (os avanços da medicina, a manipulação do DNA, a inseminação artificial, a sobrevida alcançada atualmente), psicológica (os conhecimentos obtidos e suas contribuições que fazem parte do dia a dia do homem comum), sociais (os movimentos das minorias em sua luta por direitos iguais), econômica (a influência profunda do mercado de consumo e da globalização na vida das pessoas) e cultural (vivemos hoje em um mundo sem fronteiras, onde costumes, valores, e crenças do oriente e do ocidente coabitam os mesmos espaços); esta nova ordem afeta, entre várias outras áreas, a composição familiar, que atualmente é reduzida em número de filhos e agregados, como parentes e vizinhança; o aumento das separações entre os casais e os filhos, que vão morar com os filhos do novo parceiro de um de seus pais; o aumento de mães solteiras que, por opção

\footnotetext{
${ }^{2}$ Conceito emitido em aula pelo Prof. Dr. Cornélio Pedroso Rosenburg, na disciplina “Crescimento e Desenvolvimento da Criança", do Departamento de Saúde Materno-Infantil da Faculdade de Saúde Pública da Universidade de São Paulo. 2002.
} 
pessoal ou por outras razões, acabam criando seus filhos e, muitas vezes, encarregando-se do sustento da família; os novos papéis atribuídos às mães, aos pais, aos avós. Nos dias atuais, o culto à felicidade e à individualidade tem provocado profundas mudanças nos projetos de vida de mães e pais, os quais tendem a dedicar muito mais de seu tempo a seus projetos pessoais. DEBIEUX ROSA (1999) destaca o atual enfraquecimento da figura do pai, que já era uma preocupação presente em Freud.

A crescente complexidade na forma de enfrentar a existência faz com que exista uma permanente crise de identidade, tanto nos indivíduos, como nos grupos, comunidades e nações, isto é, muitos estão confusos quanto à sua identidade, sobre quem são e como deveriam ser, para o que e para quem vivem etc. Uma boa parte da confusão do sentimento de identidade é devida à mudança de valores e das expectativas próprias da atual cultura do narcisismo e do pósmodernismo. (....) (DAVID ZIMERMMAN 2004: artigo on-line).

Sobre o comportamento social dos indivíduos, MELANIE KLEIN (1971:01) postula que:

Ao considerar, do ponto de vista psicanalítico, o comportamento das pessoas no seu ambiente social, é necessário investigar como o indivíduo se desenvolve desde a infância até a maturidade. Um grupo - seja pequeno ou grande - consta de indivíduos num relacionamento recíproco; e, portanto, a compreensão da personalidade é o fundamento para compreender a vida social $(\ldots .$.$) .$

Como vimos, as concepções sobre o homem evoluíram de visões mais simples, imbuídas de mitologia religiosa, até as mais complexas, elaboradas dentro de sistemas filosóficos e científicos. Sabemos que a influência das condições materiais, étnicas, religiosas, geográficas, da profissão, da educação, do momento histórico, das relações recíprocas, entre outras, são partes fundamentais do processo de auto-construção. Entretanto, para fins deste estudo, não obstante reconhecermos todo o exposto até aqui, buscamos dirigir a atenção para a formação da individualidade humana, em seu terreno mais profundo, a psique humana, desde seus momentos iniciais, do recém-nascido em sua relação com sua mãe e, depois, com sua família, para tentar, finalmente, reconhecer a estrutura básica de personalidade, formada na primeira infância, 
atuando na vida social. Para isso, recorremos à Psicanálise como referencial teórico para o estudo realizado.

Para FRANÇOISE DOLTO (1980), a psicanálise procura esclarecer, a partir do desenvolvimento particular de cada indivíduo, a sua 'lógica subjetiva', em outras palavras, as motivações inconscientes que levam alguns indivíduos a agirem da maneira como agem. Conforme relata BRENNER (1975), no corpo teórico da psicanálise, há duas hipóteses fundamentais: o princípio do determinismo psíquico, ou da causalidade psíquica; que a consciência é, antes, um atributo excepcional, e não simplesmente um atributo comum aos processos psíquicos, isto implica que uma grande parte das motivações humanas é inconsciente.

A concepção psicanalítica de sujeito leva em conta sua dimensão histórica e a interação da criança com os outros. Atualmente, já se conta com conhecimentos sobre etapas extremamente precoces do desenvolvimento. Para autores, como Melanie Klein, John Bowlby e Winnicott, um bom vínculo familiar na infância e, destacadamente, a relação entre a mãe e o bebê nos seus primeiros anos de vida, é fundamental para o desenvolvimento saudável da criança.

A psicanálise entende o indivíduo como um "sujeito psíquico", isto é, um ser constituído por uma vertente pulsional ${ }^{3}$ (orgânica) e suas vicissitudes, como também pelas relações de objeto ${ }^{4}$ precoces. Esta complexa interação constitui as representações internas que ele tem de si e dos outros. A obra de Melanie Klein enfatiza a importância das relações de objeto para a constituição da personalidade, como resultado da análise de seus pacientes adultos, assim como de suas observações de recém-nascidos e de crianças em seus primeiros anos de vida. Para a autora, as relações entre o bebê e sua mãe, construídas principalmente no primeiro ano de vida, período de extrema plasticidade do bebê, acabam estabelecendo, desde muito cedo na vida, o modelo básico de como ele se relaciona consigo mesmo e com os outros na sua vida. Este modelo básico o acompanhará sem grandes mudanças, na maioria dos casos, até a vida

\footnotetext{
${ }^{3}$ Pulsão é um processo dinâmico que consiste em uma pressão ou força (carga energética, fator de motricidade) que faz tender o organismo para um alvo. Segundo Freud, uma pulsão tem sua fonte numa excitação corporal (estado de tensão); o seu alvo é suprimir o estado de tensão que reina na fonte pulsional; é no objeto ou graças a ele que a pulsão pode atingir o seu alvo. (LAPLANCHE \& PONTALIS 1970: 506).

${ }^{4}$ Objeto possui em psicanálise uma conotação diferenciada. Este termo pode referir-se a uma pessoa ou algo inanimado, e diz respeito a algo que é visado pelas pulsões, é algo psicologicamente significante. Não há aqui um sentido pejorativo ou desumanizante na expressão objeto. As pulsões "escolhem um objeto" de "amor ou ódio", para realizar sua finalidade que é a sua satisfação. (LAPLANCHE \& PONTALIS 1970:407).
} 
adulta, embora ele possa viver experiências que tragam enriquecimento e progresso pessoal.

\subsection{Personalidade e caráter}

Segundo Freud, a personalidade se forma através da interação de uma herança filogenética, denominada fantasmas prototípicos, de uma base orgânica que estabelece etapas de maturação denominadas "fases sexuais" (FREUD 1972) e das relações com as pessoas que cuidam do indivíduo nos seus primeiros anos de vida. A história particular de cada um é parte fundamental na construção da personalidade, constituindo a subjetividade, a particularidade de cada sujeito. $\mathrm{O}$ grande problema do indivíduo seria o de livrar-se das tensões provenientes do mundo externo e do mundo interno, obedecendo à lei física da constância de energia. As tensões são sentidas como desprazer e a descarga dessas tensões tem a qualidade de prazer para o ser humano. Devido ao seu estado de desamparo, o bebê depende inicialmente de alguém que lhe dispense cuidados e alivie suas tensões ( a fome, por exemplo). O recém-nascido se vê, muitas vezes, às voltas com algum tipo de desconforto, e sua forma inicial de lidar e descarregar essa energia é através da motricidade, do choro, do esperneio. Aos poucos, com repetidas experiências de satisfação fornecidas pela mãe, ele vai formando uma imagem mnêmica de um objeto bom, inicialmente, um seio que o alimenta. Com poucos dias de vida, o recém-nascido dispõe de um recurso novo para enfrentar seu desprazer: a lembrança. Para a criança, que ainda não estabeleceu a distinção entre o eu e o não-eu, a realidade interna e externa, uma lembrança do seio alimentador é sentida como real e satisfaz sua necessidade por um breve momento; este fenômeno, da alucinação de um seio bom, é considerado como uma forma de auto-erotismo. Ocorre que a alucinação não é eficaz para a satisfação das necessidades do bebê. Para isso, ele depende de uma ação específica, proveniente, inicialmente, da realidade externa (mãe) que vá de encontro às suas necessidades. Essa condição de extrema e prolongada dependência é determinante na formação da personalidade do ser humano (FREUD 1976).

Na leitura de SOIFER (1992), Freud postulou o conceito de pulsão, como uma força que se origina no organismo e que impele o ser humano para um alvo em busca de satisfação, satisfação esta que é encontrada em um objeto. Diante de uma força pulsional, que surge no interior do recém-nascido, e que causa um 
desconforto que ele não pode eliminar, surge o estado de desejo e a alucinação, que consiste em investir sua energia ( $\left(\right.$ libido $^{5}$ ) em lembranças de bons objetos (que se apóiam na experiência biológica da alimentação) e que suplantem a percepção do objeto hostil; seria uma negativa em recordá-lo. Este processo é denominado recalcamento e é um dos primeiros de uma série de estratégias denominadas de mecanismos de defesa. Os mecanismos de defesa seriam organizações psíquicas destinadas a, de maneira geral, evitar a angústia. SOIFER (1992) esclarece que apreender a mamar também é um dos primeiros modelos de defesa e leva-nos a concluir que as defesas são, em princípio, normais, ou seja, estão a serviço da saúde, e afirma que a sua utilização, seja quanto à oportunidade, intensidade e conseqüências, dará a delimitação entre o normal e o patológico.

As pulsões no recém-nascido têm um caráter imperioso, buscando satisfação imediata. Elas se ligam, no psiquismo, a impressões mnêmicas e a esta ligação Freud deu o nome de "representação psíquica", que é um representante ideativo da pulsão. Estas representações pulsionais têm um vínculo estreito com a história de cada bebê e, portanto, são singulares e de origem extremamente precoce para cada ser humano.

O ser humano passa, em seu desenvolvimento, de uma situação inicial de não diferenciação, do eu e não-eu, isto é, do fora e do dentro, para uma gradual

distinção entre ele e o mundo externo, que vai aos poucos levando o bebê a perceber aos outros e a si mesmo, inicialmente, em partes, em pedaços, e que, aos poucos, vão se integrando, se unindo: em termos psicanalíticos, ele passa de uma percepção de objetos parciais para objetos totais. Isto se dá, também, em relação a si próprio, aos poucos a criança vai obtendo a percepção de si, como um ser distinto e integrado.

A idéia de personalidade nos remete a um conceito-chave que é o de inconsciente, que seria a parte maior constituinte de nosso psiquismo (FREUD 1976). O inconsciente é formado, inicialmente, por aqueles estados de tensão (ligados a uma representação psíquica), que não podem ter acesso à consciência, por sua qualidade de desconforto e perigo. São os mecanismos de defesa, que se encarregarão de manter esses conteúdos inconscientes fora do campo da consciência. Quando o bebê descobre que depende de sua mãe para conseguir restabelecer seu estado de conforto, ele passa a valorizá-la, investi-la de libido, desejá-la como um objeto extremamente importante em sua vida. Assim sendo, os impulsos que tendem a afastar, a prejudicar, a ameaçar a

\footnotetext{
${ }^{5}$ Ver definição na página 22.
} 
sobrevivência dessa mãe passam, também, a ser reprimidos e se tornam constituintes do inconsciente.

Como lembra BRENNER (1975:77): “a mãe do bebê, por exemplo, pode tornarse um objeto tão importante no seu ambiente que, no caso de um conflito entre uma exigência da mãe e um desejo direto do id do bebê, o id toma o partido da primeira, contra o segundo".

A construção do psiquismo humano inicia-se pelos impulsos de preservação da vida. Entretanto, devido à sua imaturidade neuro-fisiológica e psíquica, o bebê se apóia, inicialmente, em um adulto, que passa ser o representante externo de sua satisfação. Isto faz com que este adulto (mãe) seja investido de energia libidinal, isto é, de interesse, de importância, de amor. A energia que, inicialmente, era investida em si próprio (auto-erotismo), passa agora a ser investida também em sua mãe (objeto externo). A sensação de grande tensão e desconforto que, nos primeiros momentos de vida, era sentida como perigosa (ansiedade), desloca-se, agora, para o medo da perda do objeto de amor, isto é, aquele que supre prontamente as necessidades do recém-nascido. Esta experiência, de necessitar de alguém, e o medo de perdê-lo, vai acompanhar o indivíduo por toda a sua vida (FREUD 1976).

A necessidade do bebê, percebida como tensão interna, movimenta forças, como: a motricidade, a lembrança da existência de um seio que alimenta, além da experiência de que determinados movimentos o levam a este seio e a satisfazer sua necessidade. Este processo vai formando o que é chamado de Ego.

Inicialmente, FREUD (1976) estabeleceu que o aparelho psíquico estava dividido em três instâncias bem demarcadas entre si: o consciente, o pré-consciente e o inconsciente. Este esquema é denominado de Primeira Tópica. Esta descoberta traz a terceira grande frustração $^{6}$ para a auto-imagem do ser humano. A primeira, revelada por Galileo, tira o planeta Terra como centro do Universo; em seguida, Darwin demonstra que somos apenas uma versão mais sofisticada de nossos ancestrais, os macacos, e; finalmente, Freud, que na contra-mão das afirmações de Descartes, que postulava que a consciência era a sede da vontade

\footnotetext{
6 “Frustração é a condição do indivíduo a quem é recusada ou que a si mesmo recusa a satisfação de uma exigência pulsional" (LAPLANCHE \& PONTALIS, 1970:263). Esta condição, se não for intensa demais, é fundamental para o desenvolvimento do ego do indivíduo, isto é, a utilização de seus recursos pessoais como motilidade, memória, etc. para encontrar por conta própria os meios para satisfazer suas necessidades (LAPLANCHE \& PONTALIS, 1970).
} 
humana, demonstra a força das motivações inconscientes em nossas vidas, em outras palavras, não temos o controle que pensávamos ter sobre nós mesmos. Para ele, a consciência, embora importante na vida humana, não é o que comanda nossa vontade. Os desígnios do inconsciente são os que imperam no destino do homem.

REIS $(1984: 12,13)$ esclarece que o inconsciente não é o negativo do consciente, é um sistema regido por leis e princípios específicos e submetido a um regime energético particular. O inconsciente é o núcleo ativo da personalidade e os dois aspectos principais que constituem o inconsciente são:

1.

Um conteúdo que carece de consciência. As idéias, ou atos psíquicos, seriam os traços mnêmicos investidos de energia libidinal. "O conteúdo do inconsciente consiste, pois, em impulsos carregados de desejo. (FREUD 1915). O conteúdo do núcleo do inconsciente são as formações herdadas (protofantasias) e transmitidas de geração em geração (FREUD 1915)"

2. Um modo de funcionamento organizado com características próprias:

. no inconsciente não há contradição; dois desejos opostos podem coexistir mesmo com finalidades incompatíveis entre si;

- ele é regulado pelo princípio do prazer e não conhece a duvida ou a negação;

. ele ignora a realidade;

. ele é atemporal, isto é: ele não leva em conta a ordem histórica das ocorrências e seu conteúdo não se altera com a passagem do tempo;

. seus conteúdos permanecem ativos no inconsciente, mesmo quando passam para o sistema consciente;

- ele se organiza por relações de semelhança e contigüidade, que correspondem aos processos de condensação e deslocamento;

. a energia do sistema inconsciente é móvel e livre;

. os processos inconscientes não são aptos a passarem diretamente para o sistema consciente e, a partir daí, realizam-se na realidade.

As características, acima, que regem o sistema inconsciente, são denominadas de processo primário do pensamento.

O pré-consciente é um sistema situado entre o consciente e o inconsciente. Entre o pré-consciente e o inconsciente existe uma censura, cuja função é 
impedir o acesso de determinados conteúdos aos demais sistemas. Um conteúdo inconsciente precisa ser admitido pelo sistema pré-consciente para chegar ao consciente. O conteúdo do pré consciente é formado por representações (atos psíquicos) que lograram transpor a censura e integrar-se aos princípios do processo secundário.

O processo de funcionamento do sistema pré-consciente (o processo secundário) caracteriza-se pela forma de seu regime de energia e pela natureza de seu funcionamento. A energia do sistema pré-consciente encontra-se ligada, isto é, inibida quanto à tendência de obter descarga imediata, direta e rápida. Este modo de funcionamento pressupõe um nível mais elevado de organização da personalidade. Esse processo do sistema pré-consciente integra o princípio da realidade que, por sua vez, opõe-se ao principio do prazer, que é próprio do sistema inconsciente. Isso representa que o prazer deve ser agora obtido, conforme as condições oferecidas ou impostas pela realidade.

Para realizar as ações que visam obter, na realidade exterior, a satisfação dos desejos e das necessidades, o sistema pré-consciente necessita controlar a motilidade, o pensamento, a atenção, a memória e o raciocínio.

O sistema consciente, segundo REIS (1984:17), é definido como:

Ao consciente dá-se o nome de sistema percepçãoconsciência (Pcpt-Cs). Nele, a consciência aparece como uma qualidade momentânea que se caracteriza pelo fato da personalidade dispensar, temporariamente, atenção a certas representações pré-conscientes. Para Freud, é como se esse sistema se situasse na periferia do aparelho psíquico. Sua função principal consiste na recepção das excitações provenientes do mundo externo ou do interior do sujeito $(\ldots .$.

Ainda de acordo com REIS (1984: 17,18.):

(....). A perspectiva genética, aberta por Freud, mostra que a personalidade se constrói através dos caminhos e descaminhos do desejo. Ao afirmar que é pela história de nossos desejos que forjamos nossa personalidade, a Psicanálise torna esta noção muito próxima da de individualidade e de história de vida.

Ao considerar a personalidade como um sistema geral que se constrói através das vicissitudes de nossos impulsos, Freud ressalta alguns momentos críticos e certos pontos nodais. Estes momentos decisivos na formação do caráter e na edificação da personalidade 
são as fases libidinais pré-genitais e os complexos correlativos (complexo de Castração e complexo de Édipo).

Como foi descrito anteriormente, o inconsciente possui um núcleo herdado, através das gerações. No curso do desenvolvimento do indivíduo, alguns fatos ocorrem que o impressionam e são rejeitados, posteriormente, pelo consciente. Esses elementos rejeitados serão, entretanto, os mais ativos em nossa personalidade. Essas impressões são de natureza sexual, no sentido amplo em que a psicanálise concebe o termo, como pode ser visto:

De maneira geral, concebe-se a noção de sexualidade como sendo correlativa à noção de impulso. Como vimos anteriormente, o aparelho mental é submetido a excitações (E) de procedência, tanto externa quanto interna. Ao representante psíquico das excitações internas dá-se o nome de impulso. Assim, na definição freudiana, impulso é um conceito energético, situado entre o somático e o psíquico, que se define por quatro características básicas: origem, especificidade, objetivo e objeto. (REIS 1984: 19).

A libido tem sua origem, no organismo da criança, em regiões específicas, de onde nasce a excitação. A especificidade desta energia é uma força que busca a diminuição da sua intensidade, alcançando, assim, a satisfação, por meio de uma maneira específica e através de determinado objeto com qualidades específicas.

Em um primeiro momento, Freud dividiu os impulsos em dois grupos: os de auto-conservação (ligados às necessidades de manutenção da vida) e os sexuais. Esta divisão nos auxilia na compreensão da gênese da personalidade humana.

De acordo com REIS (1984), temos que a mente do bebê é, no princípio, relativamente simples, homogênea e onipotente. Ela funciona desconhecendo a contradição, e funciona de um modo que Freud denominou de processo primário, que seriam os processos mais antigos, que permaneceriam inconscientes e que, no bebê, seriam o único modo de funcionamento mental. Os processos mentais primários buscam, exclusivamente, alcançar o prazer e evitar o desprazer, e não levam em consideração os dados de realidade. Com a maturação e o desenvolvimento das funções psíquicas, começa a instalar-se um aprendizado, que leva o bebê a reconhecer, no mundo exterior, os objetos que podem satisfazer suas necessidades. Temos, então, que a discriminação entre objeto e 
predicado (atributos do objeto) começa muito cedo e vai construindo o processo de formação do juízo de realidade.

O princípio de realidade, ao obrigar a criança a levar em consideração a realidade na tentativa de satisfação de seus desejos, vai obrigá-lo posteriormente a postergar a satisfação de ímpeto imediato. Esta é submetida por uma satisfação tardia, porém, mais segura, que incorre em menor risco para a integridade da personalidade do indivíduo. Uma série de funções coloca-se, então, à disposição do princípio de realidade e atua no sentido de investigar a realidade exterior, agenciando ou ligando os impulsos internos "livres" a possibilidades concretas de satisfação. Essas funções que são a consciência do real, a atenção, a memória consciente, o pensamento racional etc., estão regidos pelo princípio de realidade e constituem um todo, um novo sistema de funcionamento psíquico que co-existirá ao lado dos processos primários. (REIS 1984:21).

Esse desenvolvimento, no funcionamento mental do indivíduo, leva a duas formas de pensar: uma regida pelo princípio do prazer e de natureza inconsciente, que é denominada fantasia, e a segunda, regida pelo princípio de realidade e que utiliza os processos cognitivos de natureza consciente.

O princípio da realidade implica grande diferenciação da personalidade. Os impulsos de auto-conservação são os primeiros a se submeterem ao princípio de realidade, pois são eles que exigem uma satisfação mais concreta e ajustada à realidade, para a manutenção da vida do indivíduo. Em contrapartida, os impulsos sexuais podem satisfazer-se de forma auto-erótica, sem considerar as duras exigências da realidade, podendo ficar muito mais tempo sob o domínio do princípio do prazer, sendo que algumas pessoas nunca abandonam esse modo de funcionamento.

Para a psicanálise, 'personalidade' é tomada como sinônimo de aparelho psíquico, ou mental. É uma noção usada no sentido de compreender os interesses gerais da pessoa e o jogo conflitivo desses interesses. O termo caráter é mais específico e: “implica a aquisição e estruturação de um certo número de traços ou marcas, deixadas no sujeito ao longo de seu processo de desenvolvimento, e que determinam, no interior da personalidade, uma postura típica face aos diferentes acontecimentos e situações da vida" (REIS 1984: 24).

O processo de maturação da criança desloca de certas regiões do organismo, as principais fontes de interesse e prazer. Essas zonas erógenas obedecem a uma seqüência geneticamente determinada, que se inicia na região oral, passa para a 
região anal e depois para a genital. Os impulsos que se originam em cada uma dessas regiões geram traços psíquicos indeléveis, que são precipitados no inconsciente e transformados em formas relativamente estruturadas de comportamento. Esses traços de comportamento, baseados em suas fontes orgânicas, são, em alguns casos, bastante proeminentes e daí decorrem as denominações: caráter oral, caráter anal, caráter fálico. A teoria psicanalítica fala, então, de caráter normal e de caráter patológico.

Decorre daí que caráter pode ser definido, então, como uma transformação do precipitado, relativamente estável e estruturado, resultante do desenvolvimento das organizações libidinais pré-genitais e genital.

Os mecanismos que operam esta transformação, determinando a formação de um caráter, são a sublimação e a formação reativa. (REIS 1984:25).

A sublimação é um mecanismo que dirige os impulsos sexuais pré-genitais para objetivos não sexuais, isto é, para atividades socialmente valorizadas, como o trabalho intelectual ou a criação artística, constituindo o que podemos chamar de caráter normal.

O caráter patológico é uma forma de expressão dos conflitos no interior da personalidade, conflitos estes que não se transformaram em sintomas, mas sim em modos de comportamento. Esta é uma forma que o ego utiliza para defender-se dos impulsos sexuais e opor-se ao aparecimento de sintomas. O mecanismo predominante nesta forma de defesa é a formação reativa, que é uma atitude oposta a um desejo inconsciente. A esse respeito, REIS (1984:26) relembra: "Freud fornece alguns exemplos de formações reativas através da análise do pudor, que se opõe a tendências exibicionistas; do nojo, opondo-se às tendências anais; e da piedade, como reação às tendências sádicas do sujeito."

Para a psicanálise, o comportamento do indivíduo diante de seus objetos de amor é o critério central na avaliação do desenvolvimento do caráter humano. É fato conhecido que os objetos sexuais e o tipo de relação que o indivíduo entretém com seu objeto sexual variam. Freud estabeleceu três momentos que revelam aspectos essenciais das relações com os objetos:

1. o auto-erotismo, em que a satisfação é obtida sem que haja recurso a um objeto exterior.

2. no narcisismo, em que a imagem do próprio corpo

é investida pela libido e torna-se o objeto de amor da criança. 
3. por fim, na terceira etapa do desenvolvimento, o indivíduo é capaz de ter uma imagem unificada de seu objeto de amor e percebê-la como exterior e independente dele. É o amor genital adulto.

O complexo de Édipo refere-se a um drama vivido intensamente pela criança num período, geralmente situado entre o terceiro e o quinto ano de vida. O ego da criança dessa idade transfere sua libido para o Falo, que se torna, então, seu representante. Há uma tendência de os impulsos pré-genitais se submeterem à predominância dos impulsos genitais. A figura da mãe passa a ser vista como uma 'totalidade', capaz de satisfazer todas as necessidades da criança. Essa criança, que continua vivendo nessa etapa sua fantasia de onipotência, em que seu desejo reluta em se submeter às imposições da realidade, vem sofrer uma grande desilusão, isto é, vem conhecer as limitações impostas pela sociedade, de maneira dramática, para seu ego. É como se aquela mãe, que parecia dizer a seu filho: - Você vive em um Paraíso, a esta altura de seu desenvolvimento dissesse: - Era tudo mentira. A mãe sadia desilude a criança que quer completála e por ela ser completado, ao indicar que este papel pertence a outro; que ela tem necessidades que ele (seu filho) não poderá preencher (FREUD 1974).

A função psicológica da interdição foi identificada por Freud (1974), pela 'função paterna', função esta que pode ser exercida pelo pai ou pela própria mãe, como também, por uma professora ou uma instituição. Trata-se, antes de tudo, de um confronto entre a proibição e o desejo da criança de possuir aquela mãe, fonte de todas as satisfações. Ocorre que, a princípio, a criança não se conforma com tal amputação de seu desejo e, com toda a força de sua fantasia onipotente, procura eliminar aquele que representa o obstáculo para ela, seu pai. Entretanto, a eliminação de seu rival, 'o pai', não pode ocorrer, em virtude da impotência e do amor que a criança também sente por ele. Na fantasia infantil, o pai revela-se como uma figura toda poderosa que pode ameaçar o pequeno rival com a eliminação de seu pênis (falo). Diante disso, a criança se vê impelida a renunciar a suas pretensões em relação à mãe. A criança, que antes tomava seus desejos por realidade, agora é obrigada a considerar a realidade como irredutível a seus desejos. Diante disso, ela deverá conformar-se à realidade para poder transformá-la, a fim de realizar a satisfação de seus desejos. Para a criança, a relação com o ambiente se dá nos termos de: dêem-me o que eu quero, ou façam o que eu quero, isto é, a única importância subjetiva que o ambiente tem 
para a criança é que ele é uma fonte de gratificações para seus desejos e necessidades. A criança precisa, primeiro, aceitar que é criança, para depois transformar-se em um adulto.

Esta é uma fase dramática no desenvolvimento do ser humano pois, vem destroná-lo de suas fantasias de onipotência. A este processo se convencionou chamar "processo de castração". A libido, antes investida em objetos sexualizados, agora passa a ser utilizada para objetivos dessexualizados, e social e culturalmente valorizados, processo que se denomina 'sublimação'.

O processo edipiano, para o menino e para a menina, possui aspectos diferentes. Freud estudou melhor as características referentes ao desenvolvimento desse complexo no sexo masculino. Para o menino, as excitações genitais estão associadas ao poder do Falo e são primordialmente dirigidas à mãe. Os investimentos libidinais que unem a mãe ao seu companheiro (pai) parecem constituir um ponto de desilusão para a criança que, frustrada em seus objetivos, encontra na figura paterna o "responsável" pela não realização de seus anseios. Isto desperta no menino a rivalidade e hostilidade contra seu pai. Este, entretanto, ao triunfar sobre o desejo da criança, coloca-se diante do filho como um ser poderoso e indestrutível, apto, não só a sobreviver a seus ataques mortíferos, como a vingar-se deles. Esta vingança, para o menino, toma a forma de medo de "castração", visto que esta idéia baseia-se na teoria infantil de que a ausência de pênis nas meninas é decorrente de uma punição, de uma mutilação executada pelo pai. O menino teme seu pai, ao mesmo tempo em que o admira e, encontra aí um caminho para solucionar seu dilema. Ele se identifica com o pai, introjetando as qualidades dele. Dentre elas, encontra-se a principal para a dissolução de seu conflito: a proibição do acesso erótico à mãe. O menino passa, então, ele mesmo, a proibir-se aquilo, que antes o pai lhe barrava. Resumindo, a ansiedade de castração produz o abandono da relação incestuosa com a mãe, superando o complexo edipiano; este processo que se dá, via identificação com o pai, estrutura a personalidade do menino em uma identidade psicossexual definida.

Os desenvolvimentos da questão do narcisismo trouxeram novos elementos para a elucidação do funcionamento da personalidade humana. FREUD $(1975,1976)$ postula que a libido pode ser direcionada para o próprio ego ou para um objeto. A libido é uma quantidade determinada de energia, de natureza sexual, e é a partir do ego que ela é direcionada aos objetos. 
Na concepção de Freud, a libido do ego e a libido do objeto se encontrariam em estreita relação, uma vez que entre elas operaria o que ele denominou de "Princípio de Conservação de Energia Libidinal": 'Quanto mais uma é empregada, mais a outra se esvazia' (FREUD 1914). Quando a libido está investida, principalmente, no Ego, tem-se o que Freud classificou como um estado de luto. Assim, um indivíduo em tal estado deixa de se interessar pelas coisas do mundo a seu redor, na medida em que não dizem respeito ao seu sofrimento. Por outro lado, quando a libido está investida nos objetos, caracteriza-se - caso dos estados amorosos: observa-se um desinteresse dos sujeitos por si mesmo e uma atenção concentrada no objeto de amor (REIS 1984: 43).

Temos, então, uma situação inicial, em que o ego é investido de libido, para poder defender-se de seu desamparo; esta situação, em que prevalece o autoerotismo, é denominada de narcisismo primário. Porém, a criança, incapaz de manter-se como seu próprio objeto de amor, precisa voltar-se para um objeto exterior, estabelecendo, então, o "amor objetal". Entretanto, essa condição é precária e, diante de certas condições de extrema frustração ou trauma, o indivíduo pode retirar sua libido do exterior e fazê-la voltar novamente ao seu próprio ego, fenômeno que Freud denominou de narcisismo secundário. Esta volta da libido para o ego resulta em aspectos patológicos.

Freud distingue duas formas de escolha de objeto de amor: 1) a de tipo anaclítico (aquela que se apóia sobre a figura dos pais) e 2) a de tipo narcísico (em que a escolha amorosa tem, como modelo, seu próprio ego).

Esses avanços levaram Freud ao desenvolvimento de duas importantes teorias: a teoria dos Impulsos de Vida e de Morte e a formulação de uma nova estrutura da personalidade, composta pelas instancias do Id, Ego e Superego.A noção de I deal de Ego está relacionada aos padrões éticos que o indivíduo estabeleceu para si, e que buscam reprimir os impulsos sexuais que não se harmonizam com estes padrões.

Freud postula, então, a existência de uma função psíquica especial, responsável por assegurar a satisfação narcisista do Ideal do Ego. Esta função consiste na observação do ego real, medindo e comparando-o com o Ideal do Ego. (....) O Ideal do Ego e a função autoobservadora a ele relacionada constituirão a base daquilo que será descrito como Superego (REIS 1984: 45).

Freud elabora então, em 1923, uma nova concepção da personalidade, denominada de 2 a tópica ou concepção estrutural da personalidade. Esta divide 
a personalidade em três regiões, o Id, o Ego e o Superego, que mantêm, entre si, estreitas relações.

O Id se constitui, efetivamente, como a parte obscura, 'a parte inacessível de nossa personalidade'. Ele é descrito como estando aberto, no seu extremo, a influencias somáticas e encerrando, em seu interior, as expressões psíquicas dessas influências somáticas, isto é, as expressões psíquicas das excitações biológicas. (REIS 1984:47).

É esta conexão do Id com o aspecto biológico que fará com que Freud o veja como veículo dos impulsos de vida e de morte, presentes em todo organismo vivo.

O Id se caracteriza por:
a. As leis lógicas do pensamento não se aplicam a ele. I mpulsos contraditórios coexistem lado a lado.
b. Para o Id não há negação, limites, impedimentos. Ele busca a satisfação de forma inapelável.
c. Seu conteúdo é apenas de impulsos em busca de descarga.
d. O tempo não altera seus conteúdos.
e. O Id possui um regime próprio de descarga de energia. (REIS 1984).

O Ego vem a constituir-se a partir do Id. Ele é um sistema perceptivo para as excitações provenientes do meio externo, assim como do meio interno. Funciona, também, como um escudo protetor e é a sede da consciência. Cabe a ele discriminar o que é proveniente do mundo externo e do mundo interno. Cabe ao Ego interpor-se entre os impulsos do organismo e a ação, principalmente, pela atividade do pensamento.

Para constituir-se, o Ego precisa de certa quantidade de energia, que ele retira do Id por meio de um subterfúgio que consiste em identificar-se com o objeto de desejo libidinal; assim, colocando-se no seu lugar, ele desvia para si a libido do Id.O Ego, em sua função protetora, vai auxiliar o bebê em sua imperiosa necessidade de livrar-se da tensão, operando processos para defendê-lo dessa experiência.

A esse respeito, acrescenta SOIFER (1992:22):

$\mathrm{Na}$ experiência dolorosa surge uma imagem mnêmica de um objeto produtor de dor vivida como hostil. A tensão desprazerosa induz a fugir de tal percepção, com o que se põe em funcionamento o mecanismo de recalcamento. Consiste na busca de imagens que 
substituam o objeto hostil, e para isso se apóia na experiência biológica (da alimentação) .

O estado de desejo e a alucinação do objeto desejado aparecem como conseqüência da necessidade de se fugir do objeto hostil, da negativa em recordá-lo. Assim, a energia ligada a uma impressão mnêmica (investida no objeto desejado) supera a energia da percepção do objeto hostil. Esta seria, provavelmente, uma das formas mais primitiva de defesa. Porém, com o desenvolvimento e a complexidade crescente da personalidade, outros mecanismos vão se constituindo.

D'ANDRÉA (1972: 21) comenta: “Os mecanismos de defesa tem funções protetoras e alguns deles são empregados por todos, na vida cotidiana, para conseguir estabilidade emocional. (....) Entretanto, seu uso pode ser feito de forma inadequada, ou mesmo, destrutiva, tornando-se, em si mesmos, ameaças para o bom funcionamento do ego, levando ao aparecimento de distúrbios psicológicos."

Os principais mecanismos de defesa seriam o recalcamento, a repressão, compensação, deslocamento, fantasia, racionalização, regressão, formação reativa, isolamento, anulação retroativa, negação, a projeção, a introjeção, a volta contra si, a inversão do impulso, a regressão, a sublimação, sobre cujos detalhamentos, não nos ativemos completamente no presente trabalho, por fugir ao nosso propósito, mas que podem ser encontrados, com facilidade, na literatura especializada. Deles, preocupamo-nos em esclarecer, um pouco mais, a respeito de fixação e regressão, por considerá-las essenciais para a interpretação de nossos resultados. Spitz (1979), reconhece a importância dos conceitos Freudianos das séries complementares e da fixação para o trabalho terapêutico.

As noções de fixação e regressão decorrem da concepção de fase, isto é, o deslocamento de áreas corpóreas (boca/fase oral, anus/fase anal e órgãos sexuais/fase fálica), que proporcionam intenso prazer e representações internas específicas.

Para D'ANDREA (1972:28):

Alguns indivíduos conseguem passar de um estágio de desenvolvimento para outro, porém, ao enfrentarem 
problemas de maior dificuldade, falham e retornam a um estágio anterior onde se sentiam mais seguros e gratificados. Assim, não conseguindo satisfação das necessidades de uma determinada fase, devido aos obstáculos que não consegue ultrapassar, a pessoa regride.

As fixações ocorrem, quando um evento ou uma situação afetiva marcou tão fortemente, por excesso de gratificações, ou quando os obstáculos encontrados no acesso à fase seguinte provocaram uma frustração tal, que o retorno defensivo à fase anterior parece mais imediatamente satisfatório - diante de situações em que o indivíduo se vê frente a uma grande frustração que não consegue transpor, ele tende a retornar aos objetos e tipos de relacionamento das fases anteriores em que ele se sentia gratificado.

O superego, como vimos anteriormente, é formado pela dissolução do Complexo Edípico, quando a criança interioriza a imagem idealizada dos pais. As interdições que, antes, partiam das figuras parentais, são agora realizadas internamente pela própria criança. O superego revela-se, também, como base dos ideais humanos, responsável pela consciência moral, sentimentos de autoestima e culpa.

As noções de pulsão de vida e de morte produziram uma profunda revolução na teoria psicanalítica e causaram resistência dentro do movimento psicanalítico. Essa nova teoria parte de uma questão clínica, que pode ser assim formulada: “considerando que o princípio do prazer seja o motor básico do funcionamento da personalidade humana, como pode o homem, então, repetir situações, sonhos ou atos, mesmo que Ihe sejam extremamente desagradáveis?" (REIS 1984:58).

Para FREUD (1976), essas seriam duas forças básicas da natureza que atuam no indivíduo: uma, que busca a procriação, a renovação, a união, a ligação (Pulsão de Vida); e outra, que busca o retorno ao inanimado, a morte, a degeneração, o imobilismo e a compulsão à repetição (Pulsão de Morte).

A finalidade última da pulsão de morte é a redução de toda a tensão ao ponto zero, o que só pode ser obtido na recondução do ser vivo a um estado de inorganicidade. Esta pulsão visa, conseqüentemente, à destruição da matéria orgânica, da vida e de tudo aquilo que representa união, conjunção e unidade. O impulso de morte encontra-se, inicialmente, investido no interior do organismo (autodestruição, masoquismo etc.) e é, em seguida, flexionado, em grande parte para o exterior (destruição, agressividade, sadismo etc.). A importância 
da formulação do conceito 'desta pulsão que opera em silêncio' refere-se à introdução, na teoria psicanalítica, de um princípio distintivo capaz de explicar os fatos de repetição de eventos dolorosos, do ódio, da agressividade, do fracasso e da culpa. (REIS 1984:59).

Os impulsos de preservação da vida, assim como os impulsos sexuais, são aglutinados por Freud, sob a grande categoria de Pulsão de Vida. Essas pulsões visam preservar a vida e construir unidades cada vez mais englobantes.

\subsection{As contribuições de Melanie Klein}

Melanie Klein desenvolveu sua teoria a partir do tratamento de seus pacientes adultos e da observação e do tratamento psicanalítico de crianças. A autora trouxe contribuições fundamentais para a compreensão da formação do psiquismo, esclarecendo-nos, principalmente, sobre os mecanismos de defesa, denominados introjeção, projeção e identificação projetiva. Ela acentuou o papel da pulsão de morte na constituição da personalidade e contribuiu com os conceitos de posição esquizo-paranóide e depressiva.

Para a autora, a mãe representa um papel importantíssimo na dinâmica emocional do recém-nascido. Suas descobertas ampliaram os conhecimentos sobre o que, em psicanálise, denomina-se "Relação de Objeto"”.

As relações de objeto têm seu inicio para o ser humano logo após as primeiras experiências de amamentação. Inicialmente, o impulso de preservação da vida leva o bebê a buscar alimento no seio materno. Essa simples função inicial da amamentação logo vai se tornar muito complexa e cheia de significados. Aos poucos, o aleitamento vai adquirindo um componente de prazer erótico, proporcionado pelo contato com o 'seio', que fornece, além do alimento, calor, afeto, atenção. Quem vê um bebê, sendo amamentado, percebe, claramente, a sensação de prazer e relaxamento de que ele desfruta. O bebê se apóia no prazer sexual que ele recebe de sua mãe, ao ser alimentado, para começar a investir sua libido, seu interesse em uma outra pessoa, no caso a mãe (libido objetal).

\footnotetext{
${ }^{7}$ Relação de objeto ou objetal designa o modo de relação do indivíduo com o seu mundo, relação que é o resultado complexo e total de uma determinada organização da personalidade, de uma apreensão mais ou menos fantasmática dos objetos e de certos tipos privilegiados de defesa. (LAPLANCHE \& PONTALIS 1970:576):
} 
A boca é o órgão que permite a primeira concepção da existência do mundo externo. No principio, a criança não tem noção da realidade exterior, o mundo é ela própria, envolvida com suas sensações e emoções. Quando as experiências de frustração e ansiedade, causadas pela fome, vão sendo repetidamente aliviadas por alguém, dão à criança a noção de uma realidade externa, inicialmente representada pelo seio de sua mãe. Nesta relação de aleitamento, o bebê vai introjetando a disposição afetiva da mãe em relação a ele e, assim, vai criando internamente uma representação mental daquele "objeto". A mãe vai fornecendo maior ou menor quantidade de libido (afeto, desejo, interesse, ou ansiedade, medo, rejeição) e este é um fator crucial no desenvolvimento do indivíduo. Com o tempo, a criança vai identificando aquela pessoa, seu cheiro, sua voz, seu jeito, sua reações e, aos poucos, vai "internalizando" esses aspectos, isto é, essa mãe vai ajudando a construir a subjetividade do bebê (objeto interno). Aos poucos, com a integração lenta e gradativa do Ego, a criança vai tendo uma noção mais unificada da mãe, que passa da percepção de vários objetos parciais (voz, cheiro, toque) ao que se denomina objeto total, isto é, uma pessoa como um todo.

O tipo de relação de objeto existente entre a mãe e o bebê deveria passar, de uma simbiose natural e necessária no começo da vida, para um processo lento de dessimbiotização, de forma que a criança fosse, aos poucos, adquirindo autonomia e uma noção de identidade. Mães muito ansiosas e possessivas dificultam esse processo de desenvolvimento da criança, mantendo-a dependente e com uma identidade ambígua. A ausência do pai (ou da mãe no desempenho da função paterna) como um elemento que interdita o desejo da mãe e, também, do bebê, de manter a simbiose, é, também, uma condição negativa para o desenvolvimento saudável.

Para VASCONCELLOS (1999: 102):

Quando o bebê percebe que é separado, discrimina que a mãe e o pai são pessoas diferentes dele e não apenas objeto de uso e satisfação das suas necessidades, que não tem o poder de mantê-los permanentemente à sua disposição, começa a ter de lidar com os seus limites e a elaborar a tristeza de não ser perfeito, completo, o que é muito importante para a saída do egocentrismo narcísico e a abertura para o outro, para o social, abandonando sua postura passiva para a busca ativa do contato, do 
movimento voluntário de aproximação ou afastamento, para a comunicação através da linguagem e do desenvolvimento do processo simbólico que é a base do pensamento, da ideação e da criatividade.

BRUSCATO (2001:38) cita Moore \& Fine (1990), que afirmam que uma teoria das relações de objeto compreende:

. o desenvolvimento egóico desde as relações primitivas da criança até os relacionamentos e o funcionamento mental complexos e maduros no adulto,

. os aspectos estruturados e duradouros dos padrões distintos de relacionamentos que caracterizam os indivíduos, e

. as motivações para os relacionamentos.

MELANIE KLEIN (1982) constatou que, desde o primeiro dia, mãe e filho interagem intensamente, em um mundo invisível para o observador externo, mas repleto de significações para ambos. A autora explora extensamente o papel da pulsão de morte na constituição do psiquismo do bebê. O estresse provocado pelos estados de frustração gera um intenso sentimento de ódio, vivido como uma ameaça terrorífica à sobrevivência, sob a forma de temor de aniquilamento. Quando a quantidade de energia frustradora é demasiadamente intensa para o bebê suportar, entra em ação um mecanismo mental rudimentar, primitivo, mediante o qual, a criança projeta para fora de si e "coloca" no seio da mãe todos aqueles conteúdos agressivos, dos quais ela precisa livrar-se, pois não consegue senti-los dentro dela, como algo próprio dela. O ódio passa a ser concebido como vindo de fora, tornando-se o seio materno um objeto de perseguição, que gera, na criança, um temor de ser destruída por um seio mau e perseguidor. Caso a mãe sinta-se muito angustiada com as reações do bebê e não seja capaz de digerir, internamente, toda a angústia e raiva que o bebê projeta sobre ela, acaba interagindo com a criança em um estado ansioso, carregado de sentimentos ambivalentes, de insegurança e raiva, causando, no bebê, o sentimento de que ele é possuidor de elementos muito destrutivos; e aquele seio, depositário de tal ódio, torna-se um elemento mau e perseguidor, com conteúdos maléficos e poderes de destruição e, nessas condições, seu ego não pode desenvolver-se adequadamente. Esta criança sentirá o mundo como um lugar hostil e que não tolera suas angústias, sua raiva ou, pode-se dizer, ela mesma, como um todo. A este modo de atribuir significado à experiência, a autora denominou de posição esquizoparanóide. 
Já a experiência contrária, de ser alimentado, gratificado, geram no bebê a experiência de um seio bom, gratificador, e que, também, pelo mecanismo de identificação-projetiva, faz com que ele tenha a experiência de algo externo bom, assegurador, tranqüilizante. Ocorre que a situação ideal seria aquela em que a mãe fosse capaz de perceber as angústias de seu filho, tolerá-las, metabolizá-las emocionalmente e, em seguida, aplacar os medos e as necessidades do bebê, tranqüilizando-o e reafirmando para ele que o mundo (interno e externo) é um lugar em que ele pode confiar para se desenvolver.

MELANIE KLEIN (1982) assinala que, quando há experiências suficientes em que o bebê pode sentir que seu ódio pode ser acolhido, digerido, e que sua mãe pode manter seu afeto e cuidado para com ele, ele pode passar para um outro modo de conceber o mundo e com ele se relacionar, chamado pela autora - por sua semelhança com os estados de luto e de depressão - de posição depressiva. Nesta outra maneira de atribuir significado à experiência, há o reconhecimento da destrutividade como própria e, portanto, dos danos dela decorrentes ao objeto, havendo maior consciência da separação entre sujeito e objeto. A consciência da destrutividade, como parte do próprio bebê, desperta culpa e remorso, e a atitude predominante é a de procurar reparar os danos causados, buscando, dessa maneira, evitar a perda ou destruição do objeto concebido como satisfatório.

Para a autora, posições correspondem a estados que se alternam durante toda a vida da pessoa e, mesmo, durante um mesmo dia. Em um indivíduo com desenvolvimento adequado, espera-se que haja predominância da chamada "posição depressiva".

\subsection{Cordão umbilical afetivo ${ }^{8}$}

As investigações psicanalíticas têm avançado em suas descobertas relativas a períodos cada vez mais precoces do desenvolvimento humano. Hoje, já se conhece muita coisa sobre o que se denomina "psiquismo fetal": revelações que

\footnotetext{
${ }^{8}$ Conceito emitido em aula pelo Prof. Dr. Cornélio Pedroso Rosenburg, na disciplina “Crescimento e Desenvolvimento da Criança", do Departamento de Saúde Materno-Infantil da Faculdade de Saúde Pública da Universidade de São Paulo. 2002.
} 
demonstram que o feto, ainda dentro do útero, já responde a uma série de estímulos provenientes da mãe e do mundo externo.

Logo ao nascer, a criança precisa de cuidados intensos, encontrar proteção e gratificação, devido à sua condição de desamparo, quase como um prolongamento do estado anterior, só que, agora, fora do útero. BRENNER (1975) denomina esse período de "fetalização pós-parto prolongada".

Em Inibição, sintoma e angustia, FREUD (1976: 162) escreveu:

(...) verifica-se que a ansiedade é um produto do desamparo mental da criança, o qual é um símile natural de seu desamparo biológico. (....). Essa explicação pode ser apresentada simples e suficientemente de forma biológica, porquanto, da mesma maneira que a mãe originalmente satisfez todas as necessidades do feto através do aparelho do próprio corpo dela, assim agora, após o nascimento daquele, ela continua fazê-lo, embora parcialmente por outros meios. Há muito mais continuidade entre a vida intra-uterina e a primeira infância do que a impressionante cesura do ato do nascimento nos teria feito acreditar. O que acontece é que a situação biológica da criança, como feto, é substituída para ela por uma relação de objeto psíquico com sua mãe.

À semelhança da vida intra-uterina, em que as condições de saúde física e/ou emocional da mãe afetavam diretamente o feto, o recém-nascido também está exposto a inúmeras excitações, externas ou internas, que incidem diretamente sobre ele. Idealmente, o papel de sua mãe seria o de metabolizar essas excitações sentidas com grande tensão e desconforto e tranqüilizá-lo, fazendo-o sentir-se seguro e confortável novamente. Ocorre que a mãe, também, está exposta a várias circunstâncias de vida - condições ambientais, as características psicológicas da mulher e o temperamento da própria criança que estão a afetar seu equilíbrio emocional e, conseqüentemente, sua capacidade para a maternagem. O temperamento do bebê afeta a capacidade de tolerância e a dedicação da mãe. Crianças mais vorazes, inquietas, que pouco toleram a frustração, provocam reações de inquietação na mãe, prejudicando a interação, como um todo. Fatores estressantes, como angústias despertadas na gestação, confronto entre as fantasias que a mãe tem sobre o filho ideal e desejado e o encontro com o filho real; relação da mãe e seu companheiro; estas e outras circunstâncias têm influência direta sobre o ambiente afetivo em que o bebê será recebido. 
O período pós-parto, assim como o primeiro ano de vida, é dos mais delicados na formação orgânica e psicológica da criança, e a interação pai/mãe/bebê tem um papel fundamental na constituição emocional da criança. Esta interação vai constituindo a fantasia inconsciente da criança de como a vida a receberá e vai formando uma imagem correlativa de quem ela é.

Para WINNICOTT (1966), a mãe do recém-nascido está, inicialmente, às voltas com o que ele denomina de uma doença normal, a “preocupação maternal primária", que dá a ela a capacidade de se colocar no lugar de seu filho e de responder às suas necessidades. Na mãe, a preocupação maternal primária desenvolve-se, pouco a pouco, durante a gravidez, dura algumas semanas após o nascimento e se extingue progressivamente. Posteriormente, a mãe se cura desse estado, do qual se esquece, e aceita não ser mais totalmente gratificante para seu filho: torna-se simplesmente uma "mãe suficientemente boa", isto é, uma mãe que apresenta deficiências transitórias, mas que jamais serão superiores àquilo que seu filho pode experimentar. Quando a mãe não se pode deixar invadir espontaneamente pela preocupação maternal primária, corre o risco, então, de se tornar uma "mãe terapeuta", incapaz de satisfazer as necessidades mais precoces de seu bebê, usurpando seu espaço constantemente, angustiada e culpada pela falta inicial. Ela "cuida", então, de seu filho, ao invés de deixá-lo fazer suas experiências.

Diante de uma mãe que apresente deficiências para exercer seu papel, as ansiedades da criança passam da sensação de perigo interior gerada pela tensão, frustração e desamparo, para o perigo representado pelo distanciamento, pela inadequação da mãe, sentida como o objeto que poderia aplacar suas angústias.

Para melhor entender esse fenômeno, VASCONCELOS (1999: 101) explica:

O cérebro humano é particularmente sensível no período neonatal e a mente humana, para desenvolver-se adequadamente, necessita de um referencial externo constante que se constitua no "segundo útero protetor e alimentador" que intermedia o contato do bebê com o mundo externo até este adquirir melhores condições para um contato direto menos traumático ao seu sensível mundo interno.

Os trabalhos da psicanalista MELANIE KLEIN (1971:3) esclarecem que a incapacidade para maternagem pode ser extremamente prejudicial para 0 recém-nascido: 
Formulei a hipótese de que o recém-nascido experimenta, tanto no processo do nascer, como no ajustamento à situação pós-natal, uma ansiedade de natureza persecutória. Isto se pode explicar pelo fato de que a criança de tenra idade, sem ser capaz de aprendêlo intelectualmente, sente de forma inconsciente todos os desconfortos, como se fossem infligidos sobre ela por forças hostis. Se logo lhe for proporcionado conforto em particular, calor, a maneira carinhosa com que é segurada e a gratificação de ser alimentada - isto dá origem a emoções mais felizes. Ela sente que tal conforto the advém de forças boas e, creio eu, torna possível a primeira relação amorosa da criança com uma pessoa, ou como diria o psicanalista, com um objeto.

Porém, a natureza nem sempre oferece a algumas mulheres a capacidade de proporcionar boa maternagem. A esse respeito,BADINTER (1980:18), em seu livro "O mito do amor materno", expressa que:

Se é indiscutível que uma criança não pode sobreviver e desenvolver-se sem uma atenção e cuidados maternais, não é certo que todas a mães humanas sejam predestinadas a oferecer-lhe este amor de que ela necessita. Não parece existir nenhuma harmonia preestabelecida nem interação necessária entre as exigências da criança e as respostas da mãe. Nesse domínio, cada mulher é um caso particular. Algumas sabem compreender, outras menos, e outras ainda nada compreendem. E talvez aí o mal metafísico, uma das causas essenciais da infelicidade humana. Mas será possível pensar em fugir desse mal negando sua existência?

Para prosseguirmos nesse processo de compreensão, recorremos a BALINT (1993: 20), que formulou o conceito de Falha Básica. Ele percebeu em alguns de seus pacientes uma área da estrutura da personalidade que foi mal, ou não chegou a ser constituída. Fazendo uma comparação com uma falha geológica; ele explica que, em situações de muita tensão, será exatamente esse ponto que dará inicio à desestruturação. Segundo o autor:

Em nossa opinião, a origem da falha básica pode ser identificada como uma considerável discrepância nas fases formativas precoces do indivíduo, entre suas necessidades biopsicológicas e o cuidado material e psicológico, e a afeição disponível em momentos relevantes. Isso cria um estado de deficiência, cujas conseqüências e efeitos posteriores parecem ser apenas parcialmente reversíveis. A causa de tal discrepância pode ser congênita, isto é, as grandes necessidades biopsicológicas infantis (existem crianças não viáveis e 
condições congênitas progressivas, como a ataxia de Friedreich ou os rins policísticos), ou ambientais, como um cuidado insuficiente, deficiente, aleatório, excessivamente angustiado, superprotetor, severo, rígido, muito inconsistente, inoportuno, superestimulante ou apenas sem compreensão ou indiferente.

(....) Em nossa opinião, todos esses processos ocorrem em uma relação objetal muito primitiva e peculiar, fundamentalmente diferente daquelas em geral observadas entre adultos. Definitivamente, é uma relação bipessoal na qual, entretanto, apenas um dos parceiros interessa; seus desejos e necessidades são os únicos que contam e precisam ser atendidos; o outro parceiro, embora pareça ser muito poderoso, interessa apenas enquanto pode gratificar ou decidir frustrar as necessidades e desejos do primeiro. Ademais, seus interesses, necessidades, desejos, etc. simplesmente não existem. (....).

Para finalizarmos, retornamos a MELANIE KLEIN (1982:258), que ressalva:

Devemos ter presente, entretanto, que por muito importante que sejam essas primeiras influências, o impacto do meio é da máxima importância em todos os estágios do desenvolvimento infantil. Mesmo o bom efeito da criação nos primeiros tempos pode ser, em certa medida, anulado através de ulteriores experiências prejudiciais e maléficas, assim como as dificuldades surgidas no começo da vida podem ser mitigadas através de subseqüentes experiências benéficas. Ao mesmo tempo, convém recordar que algumas crianças parecem recordar condições externas desfavoráveis sem grande dano para seu caráter e estabilidade mental, ao passo que em outras, apesar de um ambiente favorável, manifestam-se e persistem sérias dificuldades.

A essa complexa e estreita interação entre o recém-nascido, com sua fragilidade e sua condição de dependência, e uma mãe que está exposta às mais variadas circunstâncias (precedentes, presentes e futuras), que se alteram e influenciam este conjunto mãe/bebê, denominamos "Cordão Umbilical Afetivo". Este conceito pode ser pensado em conjunto com o de Potencial Circunstancial, isto é, o conjunto de circunstâncias, potencialmente favoráveis, ou não, a um desenvolvimento emocional saudável do recém-nascido.

Já nos referimos a algumas circunstâncias que, em tese, encerram, em si, um potencial para o desenvolvimento ideal. Destacamos, a seguir, circunstâncias que, na visão de alguns teóricos, encerram um potencial negativo para o desenvolvimento emocional da criança.

Dentre essas circunstâncias, SOIFER relata a importância da situação psicológica da mãe durante a gravidez, que passa por inúmeras e intensas modificações, 
mobilizando profundos aspectos inconscientes, que refletem sobre sua saúde e sobre a evolução da gestação e do parto, e, certamente, sobre suas fantasias e sentimentos em relação ao feto. Ao perceber a condição de gravidez, a mulher, em geral, reage com um comportamento regressivo. As incertezas relacionadas à gestação ativam intensas ansiedades relacionadas às possíveis ambivalências do casal em relação àquela criança. Outra ansiedade característica desta fase é o perigo do aborto. Junto a esse temor, acha-se o medo à responsabilidade assumida, responsabilidade que agora, ante o ventre já desenvolvido, adquire características de fato concreto. As transformações corporais podem conferir a sensação de fealdade e de que o corpo ficará assim, despertando sentimentos depressivos e de ciúme do marido, que "irá procurar outra" . Podem surgir angústias de "morrer no parto" e sentimentos culposos de natureza edípica (SOIFER 1980: 31).

A autora lembra que, embora muitos desses sintomas sejam a expressão da rejeição da mãe em gerar o próprio filho, eles são apenas um aspecto da personalidade, menos importante que o desejo de ser mãe.

No homem podem ocorrer várias ansiedades, dentre elas: rejeitar as formas do corpo prenhe da gestante; fantasias exageradas sobre a fragilidade da mulher e do bebê, suscitando excesso de cuidados; submissão aos caprichos, ao despotismo e à tirania da mulher, inveja em relação à gravidez, entre outras.

Todas essas circunstâncias afetam o bebê e podem ser consideradas as experiências mais precoces que interagem com seu desenvolvimento.

JOHN BOWLBY (1972:227), que se aprofundou no estudo das relações de apego mãe/bebê, estabelece três categorias de causas para a incapacidade de adequação da relação:

I. Grupo familiar sem constituição definida;

II. Grupo familiar constituído e ineficaz por:

a. pobreza extrema;

b. desemprego do responsável;

c. doença crônica ou incapacidade de um dos pais;

d. vínculo familiar instável;

III. Grupo familiar desagregado por:

a. calamidade social (guerra, fome, etc..);

b. morte de um ou de ambos os pais;

c. doença de um dos pais que requeira hospitalização; 
d. prisão de um dos pais;

e. separação dos pais;

f. pai trabalhando em outra cidade;

g. mãe trabalhando fora o dia todo.

Uma possível expressão de razões apontadas até aqui e que aparece, ao mesmo tempo, como uma circunstância que pode marcar a vida da criança, em seu processo de desenvolvimento, é a Negligência Precoce, entendida como o ato de omissão do responsável pela criança ou adolescente em prover as necessidades básicas para seu desenvolvimento. Em outros termos, consideramos Negligência Precoce a situação em que não há uma interação satisfatória entre mãe e filho durante uma fase crítica na vida da criança. Essa ocorrência caracteriza uma das condições capazes de interferir no desenvolvimento infantil. Dependendo da dimensão psicológica e neurológica dessa negligência, mesmo que a criança tenha recebido cuidados materiais e físicos adequados, mas tenha sido esse relacionamento, emocionalmente indiferente ou carente, os danos causados podem ser permanentes. Pesquisas recentes realizadas por TEICHER (2002) e seus colaboradores com adultos que foram submetidos a maus tratos e privações em idade precoce, revelam que certas áreas do cérebro, como o hipocampo e a amídala sofreram danos em sua estrutura e função. Essas áreas são responsáveis por comportamentos agressivos e irritabilidade, além de estarem ligadas às memórias afetivas. A transmissão de informações entre os dois hemisférios, realizada pelo corpo caloso, também foi prejudicada, levando esses indivíduos a fazerem julgamentos antagônicos em relação a uma mesma pessoa, que ora é idealizada, repleta de virtudes e qualidades, para no momento seguinte ser desqualificada, perdendo todas as características que possuía momentos atrás.

Relacionando esses aspectos ao objeto de nosso estudo, VASCONCELLOS (1999: 109) assinala:

A criança abandonada tem intensos sentimentos hostis e por amor aos pais e por sentimentos de culpa volta a agressividade contra si mesmo, por sentir-se extremamente má: vive a ambivalência de sentimentos de ódio e amor, não sabendo ou não tendo recursos para lidar com seus impulsos mais primitivos, instintivos, o que determina alto grau de ansiedade e inconscientemente tendem a se auto-agredir.

\subsection{Normalidade e enfermidade}


Para finalizar, consideramos importante estabelecer alguns pontos que nortearam nossa postura em relação à determinação do que é esperado dentro do espectro de comportamentos de um adolescente. Entendemos que a adolescência é uma fase crítica, de difícil adaptação e que o jovem apresenta comportamentos que, dentro desta etapa da vida podem ser considerados "normais" e até saudáveis, e que seriam considerados inadequados em outras fases da vida.

Ao analisarmos os estados psico-afetivos dos jovens, evitamos as rotulações de normal e patológico como dois estados estanques e completamente distintos um o outro. O desenvolvimento da criança e do adolescente, naturalmente gera conflitos e estes podem gerar sintomas.

Explicitando a nossa forma de entender o conceito de normal e patológico, recorremos a SOIFER (1992: 153), que assim apresenta:

$O$ conceito de normalidade em psiquiatria infanto-juvenil estabelece-se segundo as seguintes pautas: a possibilidade que o ego da criança teve de assimilar as aprendizagens pertinentes à sua idade cronológica, ou seja, a pertinente capacidade psicomotora, a inteligência esperada, a afetividade correspondente e o respectivo grau de resolução da simbiose.

Na segunda infância acrescentamos a oportunidade de cursar normalmente os estudos relativos à primeira parte do primeiro grau, o nível de socialização, a capacidade para o esporte e para as artes (sempre de acordo com a idade).

$\mathrm{Na}$ puberdade e na adolescência, a normalidade dos estudos, da destreza em geral e a inserção social correlativa proporcionarão as pautas correlatas de avaliação.

Finalmente, ao entrar na juventude, a saúde caracterizase ou pela boa inserção no trabalho ou pela feliz consecução de estudos universitários ou pelo sucesso nas relações sentimentais, ou então, por dois desses fatores ou pelos três.

Portanto, definimos sinteticamente o conceito de saúde na criança e no adolescente como o grau de organização psíquica, de desenvolvimento libidinal e de aptidões psicofísicas adequadas à sua idade cronológica.

O conceito de patológico é apresentado por Soifer, em forma de enfermidade, como:

(....)Considerou-se que uma criança ou um adolescente apresenta um quadro patológico mental toda vez que se observam nele sintomas psíquicos, psicossomáticos ou da vida de relação em consonância com conflitos 
inconscientes, ocasionados por múltiplas carências de aprendizagem que determinaram diversos pontos de fixação e por isso inibições, detenções e/ou aspectos defeituosos no desenvolvimento, com a conseqüente vigência de zonas confusionais e de desorganização no ego, a utilização de defesas que são prejudiciais e a persistência das atitudes simbióticas correspondentes a uma idade evolutiva anterior" (p.158).

Prosseguindo, SOIFER (1992:157), apoiando-se em Pichon Rivière, considera que a enfermidade pode aparecer em três áreas distintas: área 1 (mente), área 2 (corpo), área 3 (sociedade).

Quando os sintomas se apresentam na área 1, o conflito abarca unicamente o campo psíquico e, portanto , compromete somente a personalidade.

Quando aparecem sintomas no corpo, o conflito escolheu o organismo como veículo de expressão e se produz a enfermidade psicossomática. O compromisso abrange a mente e o corpo conjuntamente.

Na terceira instância - a área 3 - o conflito instala-se na interação com os demais e o compromisso expande-se para a esfera social, ou seja, afeta a personalidade, suas relações pessoais e com o mundo externo.

Considerando o contexto histórico social e conceitual apresentado, foi delimitado o objeto de estudo que resultou nesta dissertação, em face da complexidade e da abrangência do tema em questão. Realizamos, então, uma investigação entre jovens que viveram nas ruas da cidade de São Paulo, visando um maior entendimento sobre as circunstâncias em que ocorreu seu desenvolvimento, do ponto de vista da formação de sua personalidade e caráter. Buscamos compreender as circunstâncias em que os jovens investigados nasceram e se desenvolveram, do ponto de vista das condições bio-psico-sociais, por entendermos que essas dimensões do existir influenciam-se entre si e interferem mais diretamente no desenvolvimento do indivíduo. Assim sendo, procuramos resgatar as condições ambientais em que cada sujeito se desenvolveu (moradia, alimentação, número de irmãos, migração, apoio de familiares, condições de subsistência, escolaridade e outras); sobre as condições de saúde e maturação destes jovens e; o ambiente emocional em que ele passou sua infância (se foi desejado pelos pais, relacionamento familiar, dificuldades emocionais dos pais, etc.). Demos ênfase sobre este último aspecto - o ambiente afetivo em que transcorreu sua infância - pois este é o recorte que nos 
interessou investigar. Problemas no desenvolvimento da personalidade e de adaptação social ocorrem em qualquer extrato sócio-econômico-cultural, entretanto, escolhemos fazer este trabalho com jovens que viveram nas ruas, baseados na premissa de que eles abandonaram suas casas em virtude de dificuldades que não puderam superar junto à sua família, ou foram abandonados por seus pais. Estas duas situações permitem supor que suas histórias de vida foram marcadas por condições estressantes e inadequadas para seu desenvolvimento, o que poderia revelar, de forma mais exuberante, o que buscamos compreender. Entrevistamos jovens que saíram de suas casas e se encontravam em abrigos mantidos pela sociedade civil, Igreja e pela Secretaria da Assistência Social (SAS), da Prefeitura de São Paulo. O fato de elas estarem abrigadas facilitou nosso trabalho, pois elas, tendo residência fixa, podiam ser localizadas, quando necessário. 


\section{OBIETIVOS}

\section{1 Objetivo Geral}

Buscou-se descrever e compreender as principais dimensões da personalidade de alguns jovens que viveram nas ruas do município de São Paulo.

\subsection{Objetivo Específico}

Resgatar, retrospectivamente os aspectos psicológicos, sociais e circunstâncias de vida presentes no desenvolvimento de alguns jovens que viveram nas ruas do município de São Paulo.

\subsection{Hipótese de trabalho}

Partimos da hipótese de que as condições emocionais de existência nos primeiros anos de vida relacionam-se de forma estreita com o desenvolvimento da personalidade e do caráter destes jovens. Isto ocorre devido à condição de imaturidade orgânica em que o ser humano vem ao mundo. Essa imaturidade estabelece um estado de desamparo e uma necessária relação de dependência de sua mãe. Devido a essa relação simbiótica, necessária no início da vida, o recém-nascido é intensamente afetado na constituição de sua personalidade, pela natureza dos laços maternos, que por sua vez fazem parte de uma extensa rede de influências internas e externas, que influenciam, positiva ou negativamente, suas condições de maternagem. Em decorrência disso, propomo-nos a investigar em que circunstâncias viveram nossos sujeitos e como se desenvolveram em termos de personalidade e caráter.

\section{MÉTODO}


Adotou-se o método qualitativo, pois a natureza das informações que procuramos é da ordem do subjetivo e, para isso, o pesquisador precisa penetrar no mundo dos significados que o sujeito atribui à vida.

\subsection{Modelo teórico.}

FREUD em "Os instintos e suas vicissitudes" ( $p$ 137), escreve:

Como tem sido freqüentemente sublinhado, a definição exata, por muito urgente que possa ser, só é possível nas fases mais adiantadas de uma ciência. Não pode ser feita nos estágios iniciais. Tem sido muitas vezes defendido o ponto de vista de que as ciências deveriam edificar-se sobre claros e nitidamente definidos conceitos basais. Na realidade, nenhuma ciência, nem mesmo a que se considere mais exata, começa com tais definições. O verdadeiro começo da atividade científica consiste, antes, em descrever o fenômeno e, depois, proceder ao seu agrupamento, classificação e correlação. Mesmo no estágio de descrição, não é possível evitar a aplicação de certas idéias abstratas ao material em mãos, idéias derivadas de várias fontes e que certamente não são fruto, apenas, da nova experiência. Tais idéias são ainda mais indispensáveis - as quais se converterão mais adiante nos conceitos basais da ciência - à medida que o material for sendo elaborado.

No princípio, devem necessariamente possuir uma certa dose de incerteza; está fora de questão qualquer delimitação clara de seu conteúdo. Enquanto se mantiverem nessa condição, atingimos uma compreensão sobre o seu significado mediante repetidas referências ao material de observação, do qual, parece termos deduzido as nossas idéias abstratas, mas que, de fato, está sujeito a elas. Assim, estritamente falando, estão na natureza das convenções - embora tudo dependa de que elas não sejam escolhidas de modo arbitrário, mas determinadas pelas importantes relações que têm com o material empírico - relações que parecemos adivinhar antes de podermos reconhecê-las e demonstrá-las. Só depois de mais investigações e pesquisas no domínio em questão estaremos aptos a formular, com crescente clareza, os conceitos científicos nele subentendidos...Contudo o progresso da ciência exige uma certa elasticidade, mesmo nessas definições. A ciência da Física fornece um excelente exemplo ilustrativo do modo como até aqueles "conceitos basais" que se encontram firmemente estabelecidos, na forma de definições, estão sendo constantemente alterados em seu conteúdo. 
Para PICHON-RIVIÈRE (1982: 65): O objetivo central das investigações psicológicas é o campo psicológico (....) O campo psicológico é o campo das interações entre o indivíduo e o meio. Citando Lagache, PICHON (1982: 65) descreve: o campo psicológico oferece cinco classes principais de dados: 1) o entourage ou contorno. Este é concebido como uma totalidade, como um conglomerado de situações e de fatores humanos e físicos que estão em permanente interação (...); 2) a conduta exterior espontânea ou provocada, acessível a um observador, com a ajuda ou não de instrumentos, que compreende as diversas formas de comunicação, em particular a palavra; 3) a vivência, ou seja, a experiência vivida, inferida pela conduta exterior e comunicada verbalmente pelo sujeito. Ela nos dá informações sobre os aspectos psicológicos da existência $(. .) ; 4$.$) as modificações somáticas objetivas surgidas$ em uma determinada situação; 5) os produtos da atividade do sujeito, tais como um manuscrito, uma obra de arte, um teste psicológico, um relato, etc. De modo que o campo psicológico estuda o contorno, a conduta exterior, a vivência, as modificações somáticas e os produtos da atividade do sujeito".

Dentre as teorias psicológicas, utilizamos o conjunto de conceitos e hipóteses da teoria psicanalítica para a interpretação dos dados obtidos.

\begin{abstract}
Na formulação de uma interpretação no nosso campo de trabalho diário, os elementos fornecidos pelo contorno, pela conduta exterior, pela vivência, pelas modificações somáticas e pelos produtos da atividade do sujeito são tomados como indícios permanentes de uma atividade latente. Nossa tarefa é retraduzir todas essas informações, toda essa codificação feita numa linguagem típica em termos de uma fantasia subjacente nesse momento do sujeito (PICHON-RIVIĖRE, 1982:68).
\end{abstract}

O status da psicanálise, como ciência, é discutido por BIRMAN (1992: 3): “(...) Assim, apesar da exigência de cientificidade para a construção rigorosa da psicanálise, se baseando para isso nas ciências naturais e na sua demanda de quantificação, o discurso freudiano se desenvolveu de fato e de direito como uma ciência da cultura, centrado na categoria de interpretação (....)".

Sobre a interpretação encontramos em TURATO (2003:149) as seguintes citações: de Japiassu \& Marcondes (1966) - (...) “a interpretação pode ser definida, lato sensu, dentro de várias formas, como a explicação do sentido de algo ou a reconstrução de um pensamento ou texto cujo sentido não é imediatamente claro" e; de Alves (2000) - "interpretar é trazer a luz onde se 
encontra a escuridão, trocar sentidos equívocos por sentidos unívocos, transformar poesia em prosa".

\subsection{População de estudo}

Entrevistamos cinco jovens entre 15 e 19 anos, dois do sexo feminino e três do sexo masculino. Quatro sujeitos estavam abrigados na Associação Marly Cury ( $A M C$ ) e o quinto (masculino), foi entrevistado no Espaço de Convivência Nossa Senhora do Bom Parto.

Entendemos que abandonar ou ser abandonado pela família, viver circulando entre sua família e outros espaços, utilizar drogas, envolver-se com o crime, ou desenvolver uma estrutura emocional frágil, imatura, é algo que pode acontecer com qualquer sujeito, independente de sua classe social, sua condição cultural, educacional ou religiosa. Ao escolhermos nossa população de estudo, consideramos que os jovens encontrados nos Abrigos, provavelmente, teriam vindo das classes sociais menos favorecidas e esta condição foi considerada relevante, por supormos que as circunstâncias de desenvolvimento desses sujeitos se deram em condições menos privilegiadas, mais desprotegidas, inseguras, instáveis, isto é, potencialmente mais desfavoráveis, o que, em tese, reproduziria o cenário inicial que desejávamos para investigar os efeitos decorrentes das circunstâncias inadequadas para o desenvolvimento, na fase do "cordão umbilical afetivo".

Os sujeitos também foram escolhidos por estarem abrigados em Instituições, situação favorável para serem reencontrados e assim, pudéssemos dar continuidade à investigação. Isso seria quase impossível com jovens que estivessem morando nas ruas e se deslocando com freqüência. Não houve distinção de raça, cor ou credo, sendo suficiente uma história de vida nas ruas e capacidade individual de se comunicar para estes jovens participarem deste trabalho. Procuramos uma aproximação gradual para, além de esclarecer os sujeitos sobre os objetivos de nosso trabalho, estabelecer um razoável nível de confiança e empatia. As entrevistas e aplicação dos testes foram realizadas, somente após o consentimento livre e esclarecido dos entrevistados e, ocorreram quantas vezes foram necessárias para o melhor esclarecimento das circunstâncias de desenvolvimento da personalidade dos sujeitos da pesquisa. O número de encontros foi em média de cinco, sendo o conjunto de encontros concluído em tempo variável. A conclusão mais rápida ocorreu no prazo de dois 
meses e a mais longa demorou um ano, devido ao fato de o sujeito trabalhar durante o dia e estudar a noite. No total das 12 entrevistas iniciadas, sete não foram concluídas, duas pelo fato de os sujeitos não desejarem mais participar e cinco, por terem voltado para as ruas. Explicamos nosso trabalho aos responsáveis pelas Instituições, que autorizaram sua realização, alem de apresentarmos a aprovação de nossa pesquisa pelo Comitê de Ética ( Anexo 1).

O processo das entrevistas obedeceu a uma rotina flexível, consistindo em:

1. apresentação do pesquisador, objetivo do trabalho e os termos de compromisso quanto ao sigilo de suas identidades, e com relação aos fins a que se destinava aquela investigação.

2. coleta das informações sobre a vida do sujeito, essas informações foram gravadas e transcritas. Por meio desse procedimento, construímos a composição familiar, que é apresentada na forma de heredograma. ${ }^{9}-10$

3. aplicação da entrevista dirigida.

4. realização dos desenhos livres e do HTP.

5. aplicação do TAT.

A seguir, é apresentado o detalhamento dessas técnicas.

\subsection{Instrumentos e procedimentos metodológicos}

\subsubsection{Depoimento Pessoal}

Para a coleta dos dados narrados, foi utilizado o tipo de entrevista, denominado “Depoimento Pessoal”, em que o entrevistador conduz o entrevistado para o enfoque desejado, deixando-o livre em seu discurso, dentro dos parâmetros de interesse da pesquisa.

Sobre os "Depoimentos Pessoais", RIGOTTO (1998:119) cita Kosminsky (1986:32), segundo o qual, “(...) se constituem de um relato da experiência

\footnotetext{
${ }^{9}$ Ver página 47.

${ }^{10}$ Às iniciais dos indivíduos, seguem as letras $\mathrm{m}$ ou f, em caixa baixa, que designam a abreviatura de masculino ou feminino.
} 
individual que revele as ações do indivíduo como agente humano e como um participante da vida social (....). Através desta técnica, segundo Aracy Nogueira, procura-se descobrir a concepção que o indivíduo tem de si mesmo, como a que os demais têm dele". E nos fornece também duas citações de Pereira de Queiroz (1986:32): “(...) difere da história de vida na forma específica de agir do pesquisador, o qual, no depoimento pessoal, dirige diretamente o colóquio"; e ainda: "Concentrado sobre um lapso de tempo mais reduzido, permite aprofundar o número de informações e de detalhes a respeito desse espaço preciso" (1983: 147-8). 


\subsubsection{Símbolos de um heredograma}

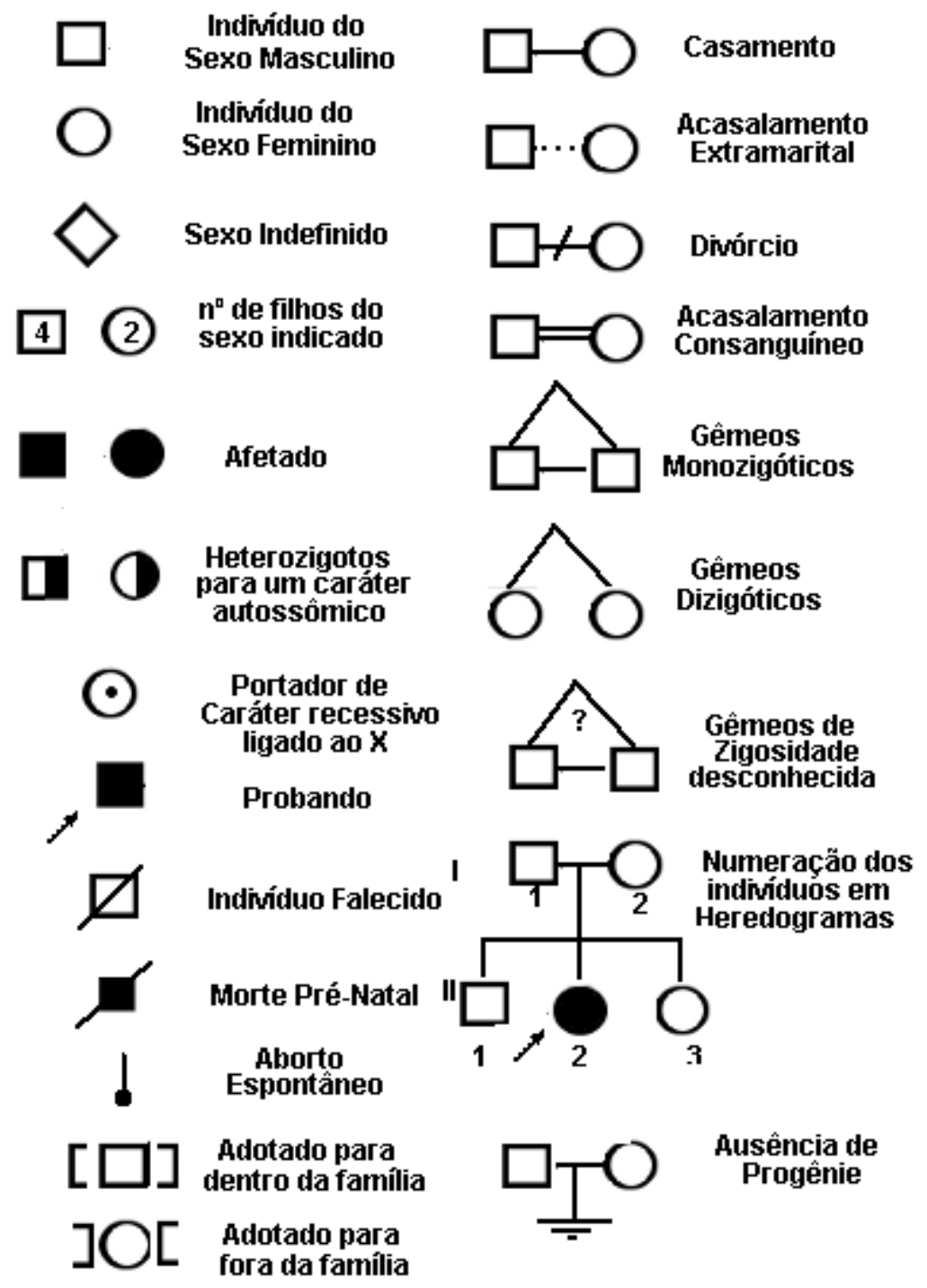




\subsection{Instrumentos de pesquisa projetiva}

A aplicação dos instrumentos de pesquisa de dados projetivos no presente estudo está fundamentada nos pressupostos apontados por SILVA (1989), no seguinte sentido: “a expressão 'métodos projetivos' (...) enfatiza os aspectos qualitativos e psicológicos, em oposição à tradição psicométrica, a qual visava uma classificação com procedimentos basicamente quantitativos e normativos".

Utilizamos os seguintes instrumentos para a obtenção dos dados subjetivos dos sujeitos: uma entrevista dirigida; dois desenhos livres; o House, Tree and Person (HTP) de JOHN BUCK; e o Teste de Apercepção Temática (TAT) de MORGAN e MURRAY.

\subsubsection{Entrevista dirigida}

Elaborada por VASCONCELLOS (1999) e utilizada em sua clínica escola, Instituto de Psiquiatria e Psicoterapia da Infância e da Adolescência (IPPIA), como instrumento auxiliar no diagnóstico de crianças e adolescentes, utilizamos a entrevista abaixo descrita, com as adaptações necessárias em face das diferenças de idade e compreensão dos sujeitos. Esta entrevista busca, de forma indireta, investigar as fantasias despertadas pelos temas abordados. As perguntas formuladas foram as seguintes:

a. Qual a melhor coisa que já te aconteceu?

b. Qual a pior coisa que já te aconteceu?

c. Qual a melhor coisa que pode te acontecer?

d. Qual a pior coisa que pode te acontecer?

e. Você sabe o que é um 'gênio da lâmpada'? Vamos fazer de conta que você encontra uma lâmpada com um gênio e que você tem direito a 3 desejos. O que você pediria?

f. Você sabe o que é uma ilha? Vamos fazer de conta que você é dono de uma ilha deserta. Quem você levaria lá para morar com você e quem você não levaria? E se pudesse levar uma pessoa só, quem seria?

g. Você sabe o que é um navio? Já fez uma viagem de navio? Vamos fazer de conta que você está fazendo uma viagem de navio com a sua família. De repente o navio começa a afundar. O que você faria? E se você só pudesse salvar uma pessoa, quem você salvaria?

h. Vamos fazer de conta que você ganhou muito dinheiro na loteria. O que você faria com esse dinheiro? 
Sobrou alguma coisa? (Se sim, perguntar o que vai fazer com esse dinheiro que sobrou).

i. Você sonha mais sonhos bons ou sonhos ruins? (Então me conte um desses sonhos - se não lembrar, pedir para inventar um.).

j. O que você vai ser quando você for um adulto? Você vai casar? Vai ter filhos? Quantos? Menino ou menina?

k. Você sabe como nascem os bebês, como eles se formam e como eles nascem?

I. Você tem namorado (a)? Já se beijaram?

\subsubsection{Desenho livre e o HTP}

De acordo com ABERASTURY (1979), a técnica da interpretação dos desenhos infantis começou, de forma sistematizada, com Sophie Morgenstern, na França. Ao tratar de um menino de 10 anos, que sofria de mutismo total, sem que qualquer exame clínico justificasse o transtorno, SOPHIE passou a utilizar o único material interpretável, que eram os desenhos que o menino fazia, a pedido da analista. Os desenhos demonstravam um estado de ansiedade aguda e eles se repetiam de modo obsessivo. A interpretação das angústias inconscientes, mas que estavam projetadas nos desenhos, fizeram desaparecer os sintomas. “O estudo do desenho, como meio de expressão da criança, tem sido um tema amplamente desenvolvido pela psicologia não analítica, porém recebeu um aporte definitivo e fundamental quando se estudou seu significado, do ponto de vista psicoanalítico" (ABERASTURY 1979).

No teste projetivo, House, Tree and Person (HTP), criado por JOHN N. BUCK e mundialmente utilizado há décadas, solicita-se que o sujeito desenhe uma árvore, uma casa, uma pessoa e, em seguida, outra pessoa do sexo oposto à primeira e que ele responda algumas perguntas sobre os seus desenhos.

Em sua obra, MÈREDIEU (1979) cita que, para Melanie Klein: "As análises infantis demonstram sempre que, por detrás do desenho, da pintura e da fotografia, esconde-se uma atividade inconsciente muito mais profunda: trata-se da procriação e da produção no inconsciente do objeto representado" p 61.

Para FRANÇOISE DOLTO (1980: 132): “Pelos desenhos, com efeito, entramos no âmago das representações imaginativas do paciente, da sua afetividade, do seu comportamento interior e do seu simbolismo". E também:

Os símbolos não servem como chaves de enigmas para os psicanalistas, como alguns gostariam de acreditar. $\mathrm{O}$ 
aparecimento de um símbolo não é o suficiente em si mesmo para permitir uma conclusão de que se trata, inconscientemente disto ou daquilo. É necessário o contexto, as descrições verbais com que a criança o rodeia, o papel que esse símbolo desempenha no jogo, no desenho, no sonho, na história narrada.

\subsubsection{TAT}

Aplicamos em nossos sujeitos o Teste de Apercepção Temática (TAT), criado por MORGAN e MURRAY. Este teste foi publicado, em sua forma definitiva, em 1943. Trata-se de um conjunto de 31 pranchas, apresentando cenas com situações humanas, variando em grau de realismo, situações, número e tipo de personagens. Foram escolhidas oito pranchas: um, 3MF, 7RH, 8RM, 9RH, 13HF, 14 e 16, que nos pareceram as mais adequadas para nosso propósito. Essas pranchas eram apresentadas aos sujeitos, sempre na mesma ordem e com o mesmo inquérito, para investigar, basicamente, quem eram os personagens; o que estava acontecendo naquela cena; o que precedeu àquele momento e; como seria o desfecho daquela estória.

MURRAY partiu do pressuposto de que diferentes indivíduos, frente a uma mesma situação vital, experimentá-la-ão cada um a seu modo, de acordo com sua perspectiva pessoal. Esta forma pessoal de elaborar uma experiência revelaria a atitude e estrutura do indivíduo frente à realidade experimentada (SILVA 1989).

Por determinação do Conselho Federal de Psicologia, essas laminas não podem ser mostradas para profissionais de outras áreas, com o propósito de não banalizar o teste.

A transcrição dos Depoimentos Pessoais, das Entrevistas Dirigidas, dos depoimentos sobre os desenhos livres e os testes HTP e TAT, encontram-se gravados em CD-ROOM e anexados a esse trabalho.

\subsubsection{Considerações éticas.}

Esta investigação foi aprovada pelo Comitê de Ética da Comissão de PósGraduação da Faculdade de Saúde Pública da Universidade de São Paulo, (anexo 
1), e encaminhado o Termo de Responsabilidade do pesquisador. para a diretoria das instituições.

Atendendo às exigências da Resolução CNS 196/96, que assegura a responsabilidade do pesquisador quando da necessidade de pesquisa com seres humanos, foi solicitado previamente o consentimento livre e esclarecido dos sujeitos da pesquisa

\section{RESULTADOS E I NTERPRETACÕES}

Neste capítulo, são apresentados os resultados obtidos seguidos de interpretação dos dados, referentes a cada um dos sujeitos, para posterior considerações finais sobre o conjunto. 

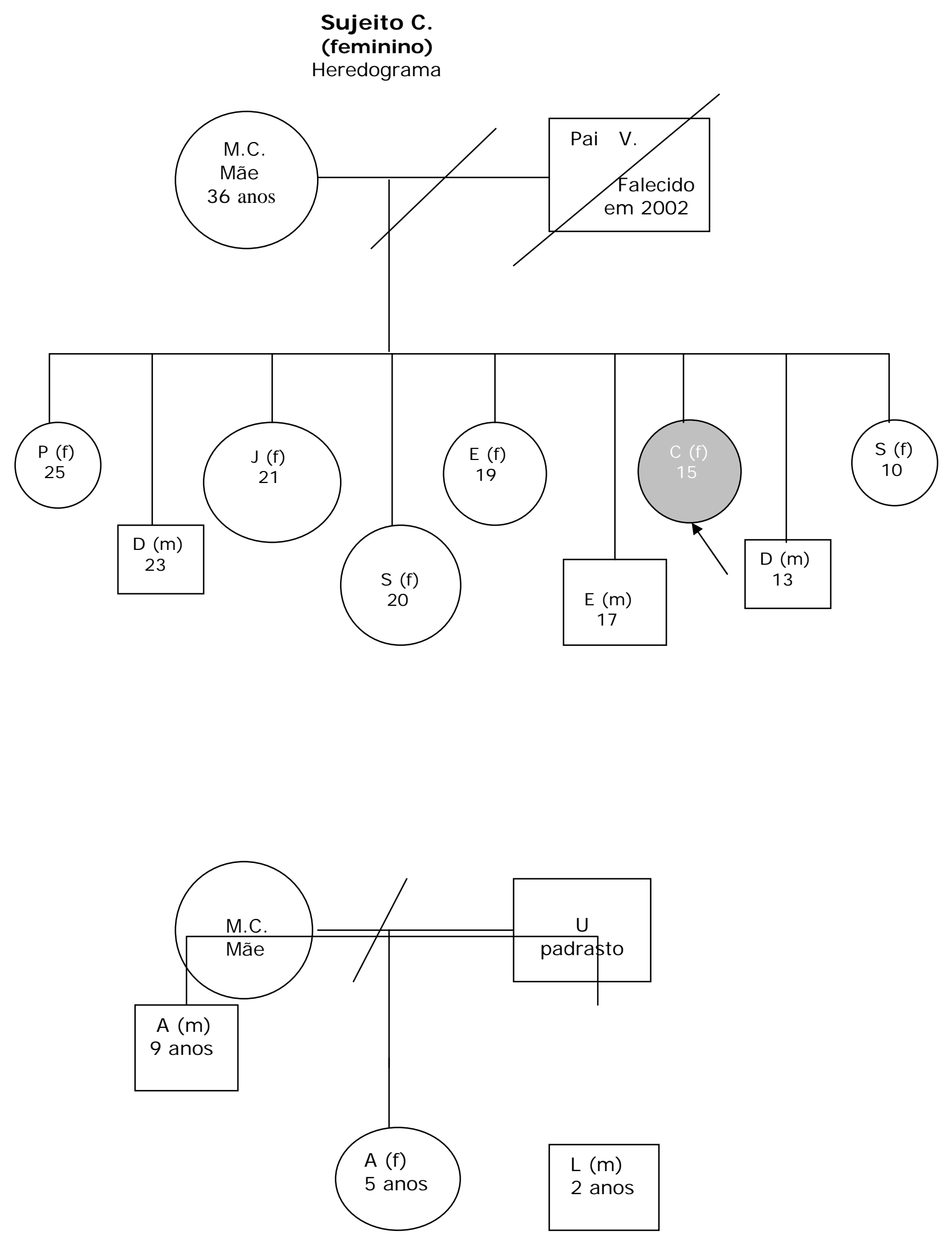


\section{Composição familiar.}

C. possui 8 irmãos e 3 meio-irmãos:

Irmãos:

1. Pf. 25 anos, mora com seu irmão D.. Desempregada no momento.

2. Dm. 23 anos, mora com sua irmã P.. Trabalha e freqüenta a Igreja dos 'crentes'.

3. Jf. 21 anos, mora só e trabalha em um restaurante.

4. Sf. 20 anos, passagem pela rua, tem um casal de filhos e está separada do marido.

5. Ef. 19 anos; passagem pela rua e uso de drogas. Atualmente mora com a mãe e tem uma filha.

6. Em. 17 anos, atualmente está na FEBEM.

7. Cf. 15 anos, está abrigada na AMC. desde o início de suas atividades. Não está trabalhando e pretende estudar em 2004. (sujeito)

8. Dm. 13 anos, atualmente mora com a mãe.

9. Sf. 10 anos, mora com a mãe.

I rmãos por parte de mãe:

10. Am. 9 anos, mora com a mãe.

11. Af. 5 anos, mora com a mãe.

12. Lm. 2 anos, mora com a mãe. 


\section{RCUNSTÂNCI AS E FASES DO DESENVOLVIMENTO}

\section{Sujeito \\ C.(fem)}

\section{Circunstâncias}

Nasce Em.

Nasce Dm.

Pai demitido por plantar maconha.

Migração da zona rural de SP. para a capital

Inicialmente moram nas ruas (pai, mãe grávida e oito irmãos)

Mudam-se para uma favela.

Nasce Sf.

Pai é demitido. Além da maconha passa a beber e usar crack

Pais se separam, ele arruma uma

amante e filhos

Pai torna-se traficante e rouba dinheiro do chefe do tráfico.

Mãe conhece U., que é alcoólatra.

Nasce Am meio irmão de $\mathbf{C}$, filho de $U$ $U$. é violento com a mãe, enteados e filhos; joga óleo fervente na mãe de C.

Mãe que era gorda, forte e trabalhadora, torna-se alcoólatra e anêmica

Mãe portadora de epilepsia

Nasce Af. meia irmã de $\mathrm{C}$ e filha de U. Mãe não pára mais nos empregos

Pai procura C., "vestido de terno e dirigindo Gol com vidro fumé", pergunta se ela quer ir morar com ele. C. recusa.

Pai de $\mathbf{C}$. é assassinado

Nasce Lm. meio irmão de $\mathbf{C}$, filho de $\mathrm{U}$

1987

1991

4 anos

5 anos

6 anos

10 anos

12 anos
Idade/ ano

1989 Nasce C (sujeito)

Cresce em um sítio na zona rural de SP onde seu pai era caseiro.

Vive nas ruas da capital até mudar-se para um barraco

C. e seus irmãos passam os dias andando pela Av. Paulista e redondezas

Mora alguns meses na casa da avó materna.

Não conheceu os outros avós.

Seu irmão E. passa a roubar e é preso

C. passa usar drogas e morar na Praça da Sé

13 anos C. guarda boas recordações do pai, baseada nas lembranças dos passeios e brincadeiras 


\section{Circunstâncias}

Padrasto é preso por violência contra a família. É solto uma semana depois e faz ameaças de morte à família de C..

$\mathrm{Na}$ época da coleta dos dados, sua mãe morava com 4 filhos e uma neta, em um cômodo com duas camas Segundo informações da Assistente Social, sua família vive em condições de miséria e a mãe de $\mathbf{C}$. não se medica com regularidade.
C. se instala na $A M C$, onde dois de seus irmãos já estavam abrigados Preocupa-se com a mãe e gostaria de ajuda-la.

15 anos Afirma ter bom relacionamento com as irmãs Pf. e Jf. Com Ef. diz que briga muito

C. lamenta: "por causa da droga minha mãe não conseguia encontrar a gente". Para ela, a 'educação foi a melhor coisa que sua mãe lhe deixou'.

Cursou o ensino fundamental e gostava das professoras.

Conta que o curso de culinária foi a coisa mais importante de sua vida.

C. gostaria de ser professora de Educação Física ou de Matemática.

Afirma ter revolta com os filhos que abandonam os pais.

Funcionários contam que $\mathbf{C}$. é muito instável, fica nas ruas, onde consome muita droga, depois passa semanas no abrigo, ou então, fica dias com sua mãe. $\mathrm{Na} A M C$, tem bom relacionamento com funcionários e colegas.

C. teme que o Juizado de Menores retire a guarda de sua mãe sobre seus irmãos. 
C. e sua família moravam em Ribeirão Preto (São Paulo), onde seus pais cuidavam de uma propriedade, como caseiros. Seu pai mantinha uma pequena plantação de maconha, para uso pessoal, dentro da propriedade e foi demitido por essa razão. C. tinha, aproximadamente, 4 anos de idade. Quando houve este rompimento com o sítio, lugar de referência para as crianças, a irmã mais velha tinha, aproximadamente, 14 anos e o mais jovem, 2 anos, apenas Sf10 ainda não tinha nascido.

A família de C. mudou-se para a cidade de São Paulo e foram morar inicialmente nas ruas, na região da av. Paulista e, mais tarde, em uma favela. Seu pai trabalhou como padeiro, mas foi demitido. Começou a beber e as discussões com a mulher e filhos se tornaram freqüentes. C. diz que seu pai nunca foi violento, apenas bebia, xingava e jogava pedras no telhado da casa, ofendia sua mãe, chamando-a de "crente sapatona". Os pais se separaram e o pai arrumou uma companheira, com quem teve alguns filhos. O pai de $\mathbf{C}$. passou a usar crack e tornou-se traficante. Certa vez, encarregado de comprar uma grande quantidade de drogas, fugiu com o dinheiro, viveu escondido e este foi o motivo de seu assassinato. Quando o pai morreu, C. tinha 13 anos, ela foi até o local onde ele foi baleado e perguntou a todos que the pudessem dar alguma informação sobre o ocorrido. Conta que, quando seu pai estava foragido, certa vez foi até a casa de seu irmão, dirigindo um "gol de vidro fumê" e vestido de terno e, lá perguntou para C. se ela gostaria de morar com ele; ela recusou o convite. C. diz sentir saudades do pai e lembra com carinho de suas brincadeiras e estórias. Diz que ele ficava alterado, nervoso, com freqüência; principalmente, quando fumava ou bebia.

Diz que sua mãe "era uma mulher gorda e forte" e que trabalhava bastante. Conta que, enquanto sua mãe estava trabalhando, ela e seus irmãos costumavam andar pela av. Paulista, o bairro do Paraíso e do I birapuera, apenas para "bagunçar"; não roubavam, nem pediam dinheiro. O único que se envolveu com roubo foi o Em17. Mais tarde, $\mathrm{C}$ e alguns irmãos passaram a ficar nas ruas, para evitar a convivência com o padrasto.

Com o tempo, sua mãe passou a freqüentar uma praça próxima ao 3o Distrito Policial, onde conheceu U., com quem passou a viver. Este era um ponto de encontro de alcoólatras. Sua mãe teve 3 filhos com U. (padrasto), alcoólatra e muito violento. Este chegou a jogar óleo fervente no rosto da mãe de $\mathbf{C}$., além 
de bater em seus enteados e filhos. Quando a mãe declarava a intenção de denunciá-lo à polícia, ele a ameaçava para que não o fizesse, até que certa vez ele ficou detido uma semana, em função de uma queixa da mãe de C. Quando saiu da prisão, foi ao encontro deles, passando a agredi-los. Nessa ocasião, C. bateu com um tijolo na cabeça de $U$. e um de seus irmãos o agrediu também. Ele foi embora, fazendo ameaças, e depois não mais se encontraram.

Sua mãe tornou-se alcoólatra, com alguns episódios de abstinência, mas atualmente está bebendo. Encontra-se magra e anêmica; o trabalho que começou ficar irregular por causa da bebida, hoje falta.

C., que morava na Praça da Sé, foi para a AMC, pois dois irmãos já estavam abrigados na casa, E.f.19 e E.m.17. Ela está lá, desde 2002, primeiro ano de existência do projeto.

C. diz que visita sua mãe quinzenalmente e, se as condições da casa fossem outras, ela iria morar com ela. Em outro momento, afirma que fica uma semana na casa de sua mãe e se cansa, então vem para a AMC e quando se cansa do abrigo, vai passar uns dias na mãe.

Diz ter bom relacionamento com suas irmãs Pf. e Jf., afirma que elas são compreensivas, diferentemente dos outros irmãos. Conta que briga muito com sua irmã Ef. Afirma ter revolta com os filhos que abandonam os pais, quando esses envelhecem, ou os matam por causa de dinheiro, lembrando de um caso recente, bastante divulgado pela mídia.

C. diz não ter tido boas experiências com as drogas, que começou usar aos 12 anos, porque era constantemente incomodada pela polícia e: - "por causa da droga, minha mãe não conseguia encontrar a gente".

Conta que além da educação, a melhor coisa que sua mãe the deixou, foi: "saber respeitar os outros". C. fez curso de culinária no Projeto Quixote e afirma que esse curso foi a coisa mais importante de sua vida; não concluiu o curso, faltando apenas duas semanas, ela alega que faltaram passes para o ônibus. Afirma que deseja voltar a estudar e gostaria de ser professora de Educação Física ou de Matemática. Diz que gostava de estudar e que teve boas experiências com suas professoras. Conta que todos os seus irmãos estudaram, mas alguns deles iam para a escola só por causa da merenda e depois de comer voltavam para a rua. No fim das aulas, pegavam o caderno de alguém, copiavam a lição e: "iam assim". 
Tem namorado e vida sexual ativa. Conta que gostava bastante de um namorado L1, de seu irmão L2 e de $M$. ., mãe dos dois irmãos, que hoje está presa.

Entre 11 e 12 anos, tinha muitos pesadelos e um que sempre se repetia; "eu era jogada do alto de um prédio". Nessa época, seu padrasto ainda morava com a família e fazia constantes ameaças a todos; quando eles se separaram e foram morar em outra casa, seu sono voltou ao normal. Conta que moraram um tempo na casa de sua avó materna, não lembra em que época, e que não conheceu os seus outros avós. Não gosta muito de sua avó, pois ela desconfia de C.: "Sempre que algo some na casa, ela pensa que fui eu, só porque nós moramos na rua".

Teme que o Juizado de Menores retire a guarda de sua mãe e encaminhe seus irmãos para alguma instituição. Receia, também, que levem sua mãe para a prisão.

C. se acha uma pessoa calma e afirma que o que a deixa nervosa "são as pessoas que falam sobre ela, sem saber direito como são as coisas". 


\section{Observações.}

Quando conversamos, C. expressou-se bem, sempre comunicativa e com bom humor, demonstrando interesse em cooperar. Segundo relatos de outros membros da casa ela é de convívio fácil com os funcionários e colegas.

Demonstrou cuidado com a higiene e aparência, aparentando bom desenvolvimento físico geral, entretanto, encontra-se bastante atrasada quanto aos estudos, porém com a vida que ela teve não podemos, sem a aplicação de testes adequados, fazer afirmações sobre sua capacidade intelectual.

Na AMC nos informaram que as fugas de C. para as ruas são muito freqüentes, quase semanais e nessas ocasiões ela utiliza muita droga; que sua família vive em condições de miséria e; que a mãe de $\mathbf{C}$. é epilética e não toma a medicação com regularidade.

\section{Resultado dos testes}

HTP

$>$ O sujeito demonstra ter razoáveis recursos de ego, mantendo certa coesão interna.

> Predominância de pensamento mais concreto, com pouca capacidade de abstração.

> Tendências a reagir de forma impulsiva.

> Dificuldades em estabelecer um modelo como referencial.

> Parece estar solto no ar, sem direção, sem perspectivas.

$>$ Notam-se sentimentos de insegurança e inferioridade.

> Uso freqüente de mecanismos de idealização.

> Conflito edipiano aparente em alguns desenhos.

TAT

> Sujeito se depara com um conflito entre o desejo de adquirir recursos pessoais para enfrentar a vida e o desejo de ser poupado, protegido das dificuldades.

> Intensa atividade de fantasias destrutivas.

> Fantasias de retaliação. 
> Presença de tendências edipianas e sentimentos de culpa

> Parece sentir-se doente e necessitando de cuidados.

> Uso da idealização como defesa das angústias.

> Percebe a presença de bons objetos internos que podem auxilia-la na vida.

$>$ Sujeito demonstra desejos de reparação.

\section{I nterpretação dos dados}

C. nada relatou como fator estressante em sua vida até a idade de quatro anos. Entretanto, devemos considerar que nosso sujeito nasceu entre dois irmãos, com menos de dois anos de diferença entre eles, o que indica que as atenções maternas tiveram de ser bastante divididas e podem não ter sido as ideais para as necessidades das crianças.

A faixa de idade, que vai dos três aos cinco anos, do ponto de vista do desenvolvimento psico-sexual, é denominada de fase fálica e caracteriza-se como uma etapa em que a criança tem de enfrentar-se com os limites impostos pela realidade. A interdição dos desejos infantis (principalmente dos desejos dirigidos aos seus pais, que são fantasiados como objetos que vão completá-las, satisfazendo todas as suas necessidades) leva a criança a se deparar com a experiência de "falta", de "impotência". Estas vivências geram na criança decepções e conflitos, que podem afetar o desenvolvimento de suas identificações com as figuras parentais, assim como a internalização de limites, valores e normas de conduta.

Exatamente nessa fase do desenvolvimento ocorrem importantes mudanças na vida de $\mathbf{C}$ :

1) grupo familiar perde o vínculo com o local de origem: com seus referenciais culturais; relações sociais; modo de vida e de subsistência, tendo pela frente o desconhecido, a insegurança quanto aos futuros acontecimentos. 
2) a mudança para a metrópole expõe a família (pai, mãe grávida e oito filhos) à falta de moradia; de meios próprios de subsistência; de referências sócio-culturais; e a falta de dignidade.

Lembremos que um dos postulados da teoria psicanalítica é que situações de perda podem afetar a personalidade de algumas pessoas, fazendo com que elas regridam, temporariamente, a modos de comportamento mais infantis ou, algumas vezes, fiquem fixados nos padrões de comportamento típicos dessas fases. Também sabemos que frustrações intensas podem levar algumas pessoas a se desorganizarem internamente, criarem padrões de comportamento destrutivos e irresponsáveis.

Aos cinco ou seis anos de nosso sujeito, seu pai é demitido do trabalho e, conseqüentemente, não pode manter a família. Em seguida, torna-se alcoólatra e passa a usar drogas pesadas; as brigas familiares tornam-se freqüentes e culminam na separação dos pais.

A mãe de C. encontra um novo parceiro com quem passa a viver, entretanto, esta foi uma união com problemas sérios. Quando C. tinha seis ou sete anos, nasce Af, filha de sua mãe com seu novo companheiro. Este era alcoólatra e muito violento, chegando a bater em seus enteados e nos filhos que teve com a mãe de $\mathbf{C}$.

O nascimento de irmãos pode, em muitos casos, re-atualizar fantasias inconscientes de abandono, e incrementar sentimentos de ciúme, rivalidade e raiva contra a mãe e o irmão, que são vistos como usurpadores do lugar e dos privilégios que a criança desfrutava. Se os cuidados maternos são sentidos pelo sujeito como insuficientes, a existência de um irmão/rival pode ser sentida como uma ameaça que irá roubar o pouco que lhe é/foi conferido.

Nesse momento de sua vida, a mãe de C., que era "forte e trabalhadora", torna-se alcoólatra, desenvolve uma anemia persistente e deixa de tratar de sua epilepsia, passando a ter problemas na manutenção do seu trabalho e, com isso, a família se vê em uma condição de miséria financeira.

C. e alguns de seus irmãos passam a ficar mais tempo nas ruas, para evitar as brigas constantes e a violência do padrasto. O irmão $E$, com doze anos (dois anos mais velho que $\mathbf{C}$.) é preso, por roubo. 
Na mesma época em que nasce L.m.., meio irmão de $C$, esta que estava com 12 anos, passa a usar drogas. Este período da vida coincide com o início da adolescência, e é quando os conflitos, que estavam latentes, ganham nova vida, trazendo uma turbulência física e emocional para todo jovem, assim como para C. A esta altura, morando na Praça da Sé, passa, em pouco tempo, das drogas leves para os solventes e o crack.

A morte do pai é sentida como uma perda significativa e coincide com a época em que nosso sujeito passa a morar com seus dois irmãos na AMC.

Destacamos, aqui, que as crianças mais jovens, com até nove anos na época da mudança para São Paulo, foram as que apresentaram envolvimento com drogas e viveram fora de casa, sendo que os dois mais velhos com, aproximadamente, 13 e 11 anos de idade na época, não tiveram essa experiência. Isso pode indicar que os efeitos das circunstâncias estressantes tiveram mais impacto sobre os mais jovens, que estavam menos estruturados emocionalmente.

O uso freqüente de drogas, geralmente, é entendido como uma fuga à realidade interna e externa. Uma boa base emocional, que contribua na estruturação de uma personalidade mais integrada e um ego mais forte, responderá às adversidades da vida com maior capacidade de suportar as frustrações e de não se desorganizar, facilmente, frente às adversidades da vida. É importante lembrar que, quando $\mathbf{C}$. começa a fazer uso dos entorpecentes, além das difíceis circunstâncias de sua vida, ela estava entrando na adolescência, o que traz antigos e novos conflitos internos.

Dentro de circunstâncias ideais de desenvolvimento, uma criança, em sua segunda infância, e um jovem, na adolescência, podem estar fazendo seu desligamento dos pais, por meio de sua socialização progressiva, de forma que suas energias estejam voltadas para, por exemplo, os estudos, atividades esportivas e para as artes. Como vimos, não foi esse o processo que ocorreu para C., seu desenvolvimento ocorreu em condições bastante adversas: viveu em situação de risco, morando nas ruas e usando drogas a maior parte de sua vida, e só conseguiu estudar alguns anos do ensino fundamental.

Apesar disso, percebe-se uma boa capacidade de adaptação à vida neste sujeito, que, possivelmente, tenha sido favorecida por um ambiente razoavelmente adequado nos seus primeiros anos de vida, enquanto morava na chácara. As adversidades que enfrentou na disputa de maternagem com o grande número de irmãos que possui e as intensas dificuldades materiais e emocionais vividas, 
depois que veio para São Paulo, parecem ter sido enfrentadas sem uma desestruturação profunda da personalidade. C. mantém um bom vínculo com sua mãe, além de bom relacionamento social com os funcionários da AMC e seus colegas de abrigo. Deseja estudar e constituir família, além de querer auxiliar sua mãe para melhorar as condições de vida. 
Sujeito E.

(masculino)

Heredograma

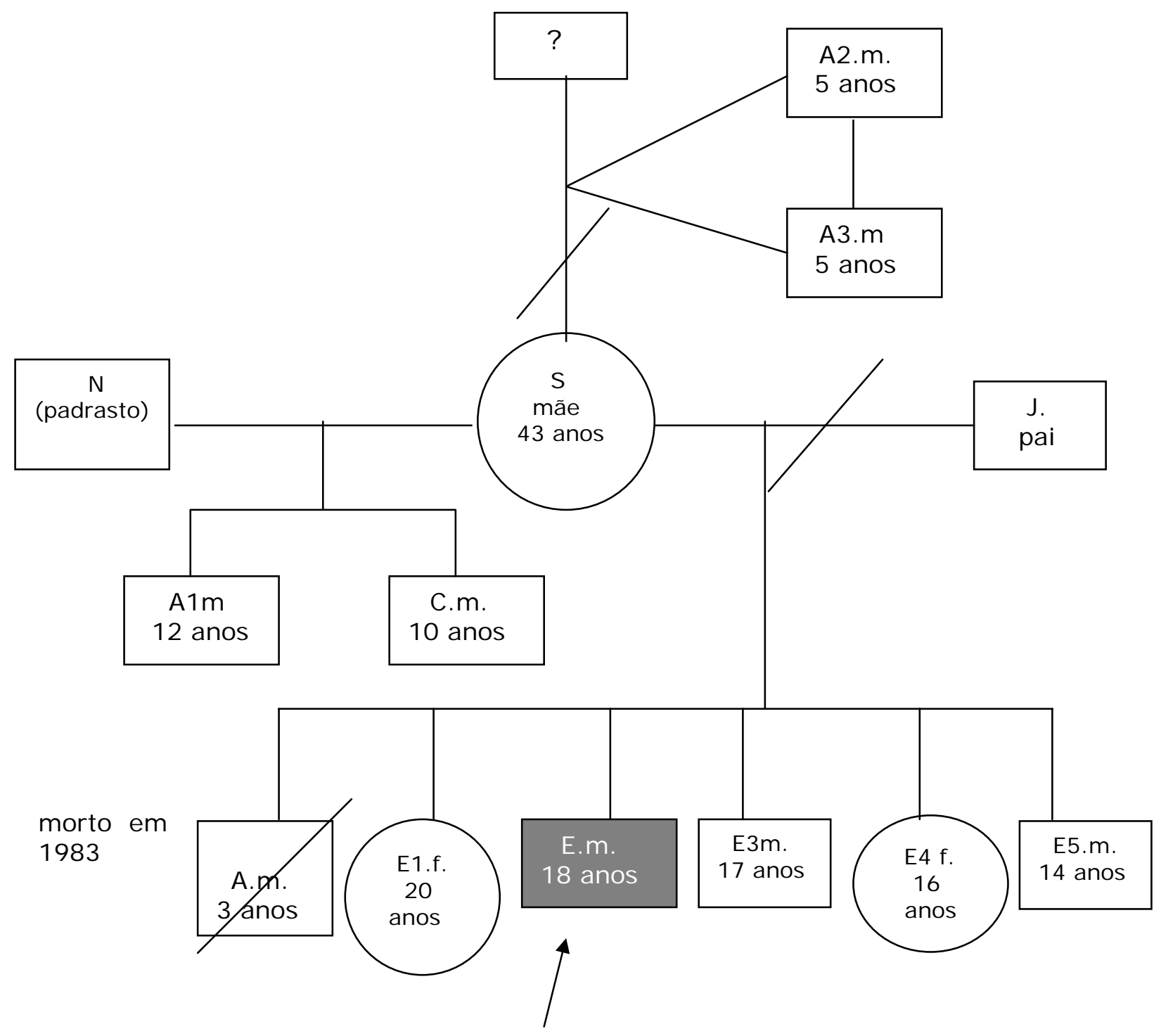




\section{Composição familiar}

Do casamento entre os pais de $\mathbf{E}$. nasceram:

1. Am. morto em 1983 com 3 anos de idade.

2. Elf.20 anos, casada.

3. E.18 anos (sujeito).

4. E3m.17 anos, mora com a mãe e estuda.

4. E4f.16 anos, mora com a mãe e estuda.

5. E5m.14 anos, mora com a mãe e estuda.

Do segundo casamento de sua mãe com N., nasceram:

6. Alm.12 anos.

7. Cm.10 anos

Sua mãe teve mais dois filhos, gêmeos univitelinos, cujo pai ela mantém em segredo.

8. A2m. cinco anos, mora com a mãe.

9. A3m. cinco anos, mora com a mãe. 


\section{RCUNSTÂNCI AS E FASES DO DESENVOLVI MENTO}

\section{Circunstâncias}

Morre Am. (irmão) com 3 anos de idade

Nasce Elf.

Nasce E3m.

Nasce E4f.

Nasce E5m.

Separação dos pais (alcoolismo paterno). Vinda para São Paulo, onde a mãe tem parentes.

Mãe une-se a um companheiro Nasce Alm.

Nasce $\mathrm{Cm}$.

\section{Sujeito E. \\ (masc)}

I dade/ ano

1983

1984

1985

1986

1987

1989

4 anos

5 anos

6 anos

7 anos E. passa levar entorpecentes para uma favela vizinha a pedido de seu tio, dono do tráfico

8 anos E. sai de casa e passa a morar nas ruas do Brás com outros garotos.

Seus companheiros tinham mais idade e trabalhavam no tráfico de entorpecentes E. já fumava cigarro e maconha.

9 anos SOS Criança encaminhou-o para sua casa apesar de sua resistência

Dois meses depois voltou a trabalhar para o tio.

Voltou a estudar e completou a segunda série, a terceira repetiu várias vezes.

Estava bastante envolvido com o tráfico e já usava crack mas não queria que As pessoas soubessem.

10 anos Foi internado com problemas nas pernas, que quase foram amputadas. Recuperouse.

11 anos Voltou para as ruas do Brás e substituiu o crack pela cola, thiner e lança perfume. Foi encaminhado para o SOS de onde fugiu indo viver na Praça da Sé. Começou a roubar e a pedir dinheiro para sobreviver.

Passou a freqüentar o Pátio do Colégio, onde conheceu Nf. por quem se afeiçoou $\mathrm{N}$. era traficante de crack e E. passou a trabalhar para ela. 
Nascem $A 2 m$ e $A 3 m$, gêmeos univitelinos de uma união extraconjugal.
E. conta que nessa época passava a maior parte do tempo usando drogas e que $\mathrm{N}$ cuidava dele, controlando e alimentando-o

Foi pego roubando e a polícia o encaminhou de volta para casa. Voltou a trabalhar para seu tio.

12 anos Ganha uma arma e passa a cobrar as dívidas que tinham com seu tio. Afirma que gostava de intimidar as pessoas com a arma. Conta que podia "ficar" com a menina que quisesse devido ao seu status.

13 anos Volta para o Brás, reencontra sua primeira turma.

14 anos Passava os dias nas estações de trem, roubando e divertindo-se "surfando" os vagões.

Caiu de um vagão, ficou 2 semanas em coma, e foi implantado um pedaço de platina em seu crânio

15 anos Foi mandado para a casa de seu pai em Pernambuco para afastar-se das drogas Durante a viagem foi pensando em matar seu pai quando o encontra-se. Após conhecê-lo desistiu da idéia, porem o ignorou indo morar com o tio. Trabalhou em oficina mecânica e desmanche de veículos. Conheceu alguns jovens e voltou às drogas.

Foi mandado de volta para SP.

16 anos Atirou em um colega que dividiu o produto de um roubo de forma injusta. Com medo de retaliação da vítima, fugiu da casa de sua mãe, voltando para a Sé. Decepcionou-se com o tio que nada fez para protegê-lo

Na Sé, foi preso e encaminhado para Unidade de Atendimento Inicial (UAI), depois de um mês voltou para as ruas. Nova prisão de onde sai em regime de Liberdade Assistida (LA).

Como não se apresentava à Assistente Social passou para condição de "busca e apreensão".

Refugiou-se na casa da tia. A essa altura começou a ressentir-se da discriminação da família.

Teve uma filha com uma namorada com quem morou por um ano. 
A avó da namorada tomou a guarda da criança.

Muito envolvido com as drogas, com a saúde prejudicada,sentindo o afastamento da família e perseguido pela polícia, pediu para ser internado em uma clínica de recuperação.

Conta que está há 3 anos sem usar drogas

Tomou um tiro na perna por causa dos desentendimentos do passado.

Afirma que muitas vezes usava drogas por sentir falta da mãe e dos irmãos.

19 anos Apreendeu o ofício de padeiro e trabalha Como monitor ensinando o trabalho à outros jovens em situação de rua. 


\section{Resumo das entrevistas}

E. nasceu em Garanhuns (Pernambuco) e veio para São Paulo com quatro anos de idade, devido à separação de seus pais. Seu pai era alcoólatra.

Falando sobre o convívio familiar, queixa-se: "a gente não convive como irmãos". E. não sabe ao certo as datas de aniversário, porque nunca comemoraram esse dia: "aniversário é só mais um dia". Diz que nunca se deu bem com sua irmã mais velha e, ao se referir aos irmãos: "a gente só se misturou depois de grande". Um grande desejo de E. é ter seu aniversário festejado.

Atualmente, sua mãe tem um companheiro residindo em casa, mas seu nome não foi registrado. Sua mãe cuida de 8 filhos.

Conta que sua mãe passava o dia trabalhando fora de casa e, desde os sete anos de idade, seu tio, que era o chefe do tráfico de drogas, pedia que ele levasse entorpecentes de uma favela à outra. E. afirma que isto acabou atrapalhando sua vida escolar. Aos oito anos, saiu de casa e, como conhecia a região do Brás, onde suas tias possuíam um comércio, veio para o bairro e juntou-se a um grupo de garotos, que viviam pelas ruas. Afirma que, nessa idade, já fumava cigarro e maconha, e suas companhias eram adolescentes, garotos bem mais velhos do que ele e, até adultos, que trabalhavam no tráfico. Próximo dos nove anos, foi encaminhado pela polícia para o SOS Criança, que o levou de volta para casa, apesar da sua resistência. Ele afirma que, nessa ocasião, toda a família passou a tratá-lo bem, "pensando que assim eu não ia voltar para a rua".

Dois meses depois, já havia se reaproximado de seu tio e voltou a trabalhar para ele. Nessa época, voltou a estudar e completou a segunda série, a terceira ele repetiu várias vezes, sem finalizá-la, segundo E., "por motivos de trabalhar com a droga, aí pra mim o ritmo da droga virou uma rotina". Diz que, aos nove anos, já usava o 'crack', mas não queria que ninguém soubesse. Aos onze anos, voltou para o Brás, onde se juntou a uma turma, foi largando o 'crack' e substituindo por cola, Thiner, lança-perfume: "eu gostava da brisa, da loucura que passava, um modo criativo assim entre aspas, um jeito diferente, gostei". Foi novamente encaminhado para o SOS, de onde fugiu, indo para a Praça da Sé. Conta que a Sé é dividida ao meio, pelo chafariz, e isso delimita dois 
territórios, de um lado ficam os que usam 'crack' e do outro, os que usam cola. Começou a roubar e a pedir para ter o seu dinheiro. Em seguida, passou a freqüentar o Pátio do Colégio, onde passava a maior parte do tempo usando drogas e onde conheceu N., uma jovem traficante, por quem E. se afeiçoou. N. cuidava dele, não deixando consumir droga, sem antes comer, e, quando que ele passava mal, ela Ihe dava leite. E. trabalhou para ela, como traficante. Nessa época, E. foi pego roubando e os policiais o encaminharam de volta para sua casa, onde ele ficou por quase um ano. Voltou a trabalhar para seu tio, parou de usar 'pedra' e passou para a cocaína e o álcool, ganhava dinheiro, comprava suas roupas e "isso sem minha mãe saber, até tinha as desconfianças dela". Conta que, por ser sobrinho do chefe do tráfico, recebeu a incumbência de cobrar as dívidas que tinham com seu tio. Ganhou, então, um revólver calibre 38, aos 12 anos de idade. Passou a intimidar os que tinham dívida, e a ser temido pela vizinhança e, até, "pelo diretor da escola". Gostava da condição de poder, que entre outras vantagens, despertava o interesse das meninas por ele. Com 13 anos, voltou para as ruas, novamente, voltando para o Brás, ao mesmo local e à mesma turma que ele encontrou, na primeira fuga. Com essa turma, passava os dias nas estações de trem das proximidades, roubando e divertindose. Certa vez, em cima do trem, percebeu a segurança esperando-o na estação que se aproximava. Pulou em um telhado, que quebrou, e ele caiu perdendo os sentidos; acordou de um coma, 2 semanas depois, com um pedaço de platina no crânio.

Aos quinze anos, ele e mais dois amigos roubaram um ônibus e, na hora da divisão do dinheiro, um dos jovens tentou esconder uma parte maior para si. Isso fez com que E. tomasse o dinheiro do rapaz e atirasse em sua perna. Nessa época, ele estava morando na casa de sua mãe, de onde saiu, por medo de retaliação, por parte da vítima. Conta que esperava que seu tio o protegesse, mas que esse nem tomou conhecimento do caso. E. voltou para a Sé e, depois de um tempo, foi preso novamente e encaminhado para a Unidade de Atendimento Inicial (UAI), onde ficou um mês, em seguida, foi re-encaminhado para o SOS e daí, foi para a rua. E. conta que houve uma nova prisão, que gerou um processo, em que ele ficou em regime de semi-liberdade. Conta que, na instituição onde ficavam os jovens (Unidade Educacional - UE), também em regime de semi-liberdade, ele encontrou "todo mundo que é do crime". Neste local, o jovem sai durante o dia para estudar ou trabalhar, retornando à noite. A instituição providencia, em alguns casos, trabalho ou estudo. Depois de quatro 
dias, E. saiu com alguns amigos e foi parar em uma favela próxima, e foi logo apresentado para o dono do tráfico. Esse pessoal conhecia o tio de E. e vários de seus amigos. E. passou imediatamente a trabalhar no tráfico e não voltou para a UE. Passadas algumas semanas, E. foi para a casa de uma tia, onde ficou escondido, pois havia entrado em situação de "busca e apreensão", por ordem do Juizado de Menores. Fez amizade com a vizinhança e, logo, começou a participar do grupo de usuários.

E. conta que sua tia começou a ficar desconfiada de seu vício e que a esta altura sua mãe já sabia: - “aí fiquei assim, comecei a ser discriminado já pela minha família toda, que não curtia o negócio, (...) eu tava sem chance (...) pra eu poder me regenerar e tal, então me afundei mesmo".

E. começou um relacionamento com uma garota, e os dois tiveram uma filha. Ele morou na casa da namorada, aproximadamente, por um ano. A avó tomou a guarda da menina, porque sua neta estava envolvida com drogas. E. diz que voltou para a casa de sua tia e, depois disso, ele nunca mais viu a filha, nem a mãe da menina.

Muito envolvido com as drogas, sentindo sua saúde prejudicada e perseguido pela polícia, E. pediu à sua tia para ser internado em uma clínica para drogadictos. Com a ajuda de um advogado do Projeto Quixote, conseguiram uma autorização judicial para modificar a ordem de prisão em internação em uma clínica, para tratamento de seu vício. "Fiquei 10 meses na casa de recuperação evangélica".

Conta que lutou contra a vontade de usar a droga, enquanto estava na clínica, e conseguiu um certo controle sobre si mesmo e o exerce até hoje, quando já está em liberdade. Conta que, algumas vezes, "dá uma escapadinha", mas esforça-se muito para não recair. Após ter saído da clínica, o juiz decretou a condição de Liberdade Assistida, e ele passou a ser acompanhado por uma assistente social. Afirma que está há quase três anos sem usar "nada".

Em outro momento, revela que o que o levou para a casa de recuperação foi "mais a questão que eu estava sentindo falta da família, eu tava percebendo que eu tava me afastando da minha família". Mesmo tendo oito irmãos, não tinha convívio familiar, pois passava a maior parte do tempo na rua e, quando vinha para casa, chegava drogado e não se relacionava com ninguém.

Para ele, os meninos de rua eram tratados como irmãos. "Ali quando um tinha uma coisa, pode ser um pedaço de pão, pode ser qualquer coisa, sempre divide 
ali com os outros, não só o pão, a comida, mas como a droga, tudo entendeu? A gente andava junto, a gente se chamava de irmãozinho".

Conta que, quando ficava triste, com saudades de sua mãe, procurava se drogar ou, então, roubava dinheiro e ia com uma prostituta para um hotel da região da rua Guaianazes, ou, então, ficava sentado em um 'mocó', embaixo das escadas da Sé. "O que me fazia falta era minha mãe do meu lado, minha mãe sempre esteve do meu lado, mas não do meu lado totalmente, porque ela nunca chegou pra conversar comigo, pra saber o que tava acontecendo, pra saber porque eu to triste, a minha mãe..., o trabalho dela..., era só isso trabalhar, colocar as coisas dentro de casa e o resto vocês que se virem, entendeu?".

E. diz que, hoje, aconselha sua mãe a controlar melhor seus irmãos menores, para que eles não tenham o mesmo destino.

Afirma que, quando sentia saudades e voltava para casa, sua mãe sempre o aceitava de volta, mas depois, "não olhava na minha cara".

Conta que não se lembra de seu pai na infância e, com 15 anos de idade, foi mandado para a casa dele, porque queriam afastá-lo de São Paulo, por causa das drogas. E. conta que foi com a idéia de matar seu pai, pois sentia muito ódio dele. Quando chegou em Garanhuns (cidade onde o pai morava, no estado de Pernambuco), demorou 3 semanas para falar com o pai e, com o tempo, seu ódio foi arrefecendo. Na cidade, trabalhou em uma mecânica e, depois, em um desmanche de carros. Namorou algumas meninas, inclusive, sua prima, com quem manteve um relacionamento escondido. Conheceu os usuários de crack e cocaína e passou a andar com eles. Seu tio, percebendo o que estava acontecendo, mandou-o de volta para São Paulo.

Um fato que marcou sua vida foi uma namorada, que era de uma classe social mais elevada, e evangélica, essa moça "desafiava os pais dela para ficar comigo" e estava sempre me chamando para ir para a Igreja e queria me tirar das drogas.

Conta que, em conseqüência de seu passado, levou um tiro na perna, depois que saiu da clínica de recuperação

Perguntado sobre sua saúde, ele conta que teve um problema na perna, "que ninguém sabe o que é". Diz que era para ter amputado a perna, que ficou 3 meses sem andar, com uma mancha na perna e no joelho, "e aí, uma vez tava uma perna boa e a outra não estava, aí perdi a noção da perna, não sentia mais 
minha perna, mas de lá pra cá melhorou, os médicos falaram que não pode acontecer duas vezes, da segunda vez não passa (...), isso eu era pequenininho, eu tinha uns dez anos de idade".

\section{Observações.}

O jovem E., que participa das atividades do Centro de Convivência Nossa Senhora do Bom Parto, foi convidado a ser entrevistado para este trabalho, aceitando com facilidade e interesse. Demonstrou certo orgulho em fazer parte de uma pesquisa, e foi bastante colaborador.

E. aparentou ser um jovem comunicativo e que mantém bom contato social com os funcionários do Abrigo, assim como com os meninos que lá freqüentam. Ele aprendeu a técnica e auxilia um funcionário, que dá aulas sobre panificação para os jovens interessados, ganhando, por isso, uma bolsa auxílio do Centro de Defesa dos Direitos da Criança e do Adolescente (CEDECA), uma parceria entre o Centro de Convivência e o Governo do Estado.

Pareceu-nos que ele demonstrava certa expectativa em ser ajudado, uma ajuda muito indefinida, inespecífica, que surgia por meio de pequenos sinais, talvez um anseio em compreender o que acontece com ele, ou receber algum tipo de orientação.

No primeiro dia, mostrou-se bastante falante e pareceu querer "impressionar" o entrevistador, com sua história. No transcorrer das entrevistas, seus conflitos e sua dor começaram a transparecer.

E. é o único, entre seus irmãos, que viveu em situação de risco, os outros moram com a mãe e uma está casada. Ele ressente-se da vida que levou e afirma que a companhia de sua mãe lhe fez muita falta, embora não demonstre ressentimento (consciente) por ela. Queixa-se da ausência de alguém que tivesse cuidado dele, orientando-o "para o bem". Afirma que seu melhor amigo era uma pessoa que estuda, trabalha e freqüenta a igreja e ele sempre o orientou para o bem.

Aparenta bom desenvolvimento geral, quanto ao aspecto físico, porém, é indicado um exame mais detalhado, para investigar possíveis seqüelas neurológicas, relacionadas com o uso intenso de álcool e drogas, com início aos sete anos de idade, e possíveis comprometimentos causados pelo traumatismo 
craniano grave, com episódio de coma e implantação de placa metálica no crânio.

Observa-se uma extroversão levemente exagerada, dando a impressão de um estado de ansiedade permanente. Seu discurso é exaltado e ininterrupto, deixando pouco espaço para a interlocução.

\section{Resultado dos testes}

HTP.

> O sujeito demonstra fortes tendências de cisão do ego, isto é, como se fosse um "eu", que pensa, e um 'outro,' que age impulsivamente.

> Desejos de estabelecer contato com o mundo externo e de obter apoio de pessoas que possam ajudá-lo.

$>$ Intensa necessidade de aceitação.

> Fantasias de esvaziamento interior de aspectos, como: recursos pessoais, auto-estima e controle dos impulsos.

> Tendências à procura de satisfações, dentro da modalidade oral, isto é, imediatismo e voracidade.

> Sujeito demonstra sentir a influência do passado, vivida como feridas.

$>$ Os desenhos demonstram, também, que o sujeito possui uma boa estrutura interna.

\section{TAT}

As análises das estórias indicam:

$>$ O sujeito demonstra sentir-se incapaz de fazer frente aos desafios de uma vida, que exija um funcionamento, predominantemente, dentro do processo secundário, e sente uma forte necessidade de apoio de outras pessoas.

> Responsabiliza os outros por sua história de vida e, em outros momentos, lamenta não ter tido recursos pessoais para ter evitado viver a vida que levou. 
> Conflito entre as formas mais primitivas de satisfação, como imediatismo; voracidade; inveja e impulsos agressivos e a tendência a assumir responsabilidades e comportamentos socialmente valorizados.

\section{I nterpretação dos dados}

A mãe de E. perdera um filho, que 'morreu de susto'(sic), com três anos de idade, em 1983. Ainda sob o efeito desse luto, dá à luz, no ano seguinte (1984), à E1., irmã mais velha de nosso sujeito; a seguir, em 1985, nasce E. (sujeito); em 1986, nasce seu irmão E3.; em 1987, nasce E4; e, em 1989, nasce E5. Chama a atenção o curto intervalo de tempo entre os nascimentos.

Com quatro anos de idade, os pais se separam e sua mãe migra para São Paulo, com quatro filhos. O motivo alegado para a separação foi o alcoolismo do pai. Sua família vai morar em uma favela onde, também, residiam alguns parentes da sua mãe. Um ano depois da chegada, sua mãe passa a viver com $\mathrm{N}$, que se torna padrasto de E.. Aos seis anos, nosso sujeito ganha outro irmão, Alm..

Esses fatos nos levam a crer que as condições de vida foram onerosas para toda a família: um ambiente conjugal conflitivo com um alcoólatra, que culminou na separação do casal; a mãe de E. passou de quatro a cinco anos entre gestações, partos, amamentações e cuidados com as crianças, o que exige um dispêndio de energia, física e emocional, bastante grande, e que, em tese, poderia afetar sua disponibilidade para atender, razoavelmente, às necessidades dos sujeitos envolvidos. De acordo com o depoimento de nosso sujeito, ele foi o único, entre os irmãos, que sofreu com dificuldades emocionais, fato que precisaria ser investigado, pois E. pode "fantasiar" que ele foi o único a enfrentar dificuldades. Se é verdade que $\mathbf{E}$. foi o indivíduo que teve sua personalidade mais comprometida, dentre todos os irmãos, podemos considerar algumas hipóteses para compreender um pouco sobre o processo: é possível que, nos momentos em que ele mais precisava da sua mãe para estruturar-se emocionalmente, ela poderia estar vivendo alguma situação específica (de que não tivemos conhecimento) que, somada às condições já descritas, interferiu (dentro de uma dinâmica de sinergia) em sua disponibilidade para as necessidades de E.; é preciso lembrar, também, que há crianças pouco viáveis para um bom desenvolvimento, bebês que apresentam características inatas, que desfavorecem seu desenvolvimento, como fortes sentimentos de raiva diante das frustrações e que podem levá-lo à sensação de aniquilamento, despertando 
- uso intenso de mecanismos de defesa; essa circunstância pode dificultar sua capacidade de receber os objetos bons, que Ihe são oferecidos, dificultando, assim, sua vivência de que o mundo é um bom lugar para se viver e que ele dispõe internamente de objetos bons em que ele pode se apoiar e confiar.

Nosso sujeito apresenta, atualmente, com a idade de 18 anos, uma série de traços de caráter e mecanismos de defesa, típicos da etapa denominada fase oral, a mais primitiva no desenvolvimento psicosexual do indivíduo (de zero à um ano e meio de vida), e a mais relacionada com a interação mãe/bebê. Dependência das drogas, carência afetiva acentuada (lamenta, com freqüência, que sua mãe não dispensava atenção que ele desejava, e que ela o deixara muito 'solto'), uso intenso de mecanismos de defesa, como: idealização e cisão, por exemplo, quando declara travar cotidianamente uma intensa luta interna entre: uma tendência para voltar às drogas e às ruas; e outra que deseja tornar-se uma pessoa responsável por alguém ou por algo, e resgatar a aceitação de sua família) ou, quando aspira viver situações de vida ideais, sem restrições, sem limitações e dificuldades. É interessante observar o contraste entre a vivência (idealizada) de fraternidade extrema, que ele tem com seus "irmãozinhos" de rua, e sua percepção de que ele não poderia contar com eles, de fato, de que aquilo tudo não passava de aparência. E. parece experienciar a vida de um modo predominantemente persecutório: a predominância de sentimentos de raiva e agressividade tem, como conseqüência, os sentimentos de perseguição, conseqüência da fantasia de que, aquele ódio depositado nos objetos, poderá voltar-se contra o sujeito. Esta maneira de sentir a vida é notada em suas declarações sobre sentimentos, que surgem de dentro e podem destruí-lo, ou que surgem de fora, como temas de vingança e morte que permeiam as entrevistas e os testes.

Podemos notar uma inibição do desenvolvimento psicosexual de E., que também se expressa em suas palavras: "Eu não consigo me imaginar adulto".

Fica nosso questionamento: por quê, aos oito anos de idade, nosso sujeito vai morar nas ruas, se ele não relata maus tratos infligidos por sua família, nem situação de miséria ? Nessa idade, as crianças estão em plena fase da latência, que se caracteriza por uma etapa de aprendizado, em que os conflitos edipianos permanecem reprimidos, para eclodirem somente mais tarde, perto dos treze anos de idade. Se não encontramos motivos na realidade externa, devemos procurá-los na realidade interna de nosso sujeito. 
Nosso sujeito funcionava, regido, principalmente, pelo processo primário de pensamento, que se caracteriza pela necessidade de gratificação intensa e imediata, e que não considera o momento adequado para sua concretização; não discrimina os riscos envolvidos em suas ações e as perdas concomitantes; parece nunca se satisfazer; é regido pelo pensamento onipotente; não tolera os limites, tampouco a frustração. Nesta linha de raciocínio, podemos compreender um pouco mais do comportamento de E., como a ligação de nosso sujeito com seu tio, que é alguém que demonstra interesse por ele. Para uma criança carente, este é um bem de alto valor e ela poderá não considerar os fatos, sob uma ótica mais ampla e mais realista, sendo assim, E. passa a trabalhar para o tio, no tráfico de entorpecentes, já aos sete anos de idade. É importante considerar que o tráfico é um universo imensamente sedutor para a garotada de seu entorno, pela existência de um mito do traficante: às vezes vilão, às vezes herói, mas, sempre poderoso. Existe, também, a questão do ganhar um bom dinheiro com pouca idade (se ganha mais em uma "mulazinha" do que horas ou dias pedindo no farol), o que conduz à questão da independência - posso fazer coisas que adultos fazem, posso ter dinheiro, posso comprar, etc - e, existe a sedução da rua, suas possibilidades infinitas de satisfações instantâneas, um espaço lúdico, de aprendizagem e de exploração do mundo.

Podemos pensar que houve um fracasso na elaboração das fantasias infantis de onipotência, que deveriam submeter-se gradativamente às exigências e aos limites da realidade, e assim, E. começa uma jornada que só vai ser interrompida aos quinze anos, depois de ter sofrido na carne as conseqüências de sua recusa em aceitar os próprios limites, quando já colecionava em sua história, a dependência de drogas pesadas, o convívio com o crime e a violência, a quase amputação das pernas, um implante de uma placa de platina em seu crânio, tendo atirado em outro jovem e sido vítima, também, de um tiro; a discriminação social e familiar.

A trajetória de E. demonstra a influência vigorosa de impulsos de autodestruição e de agressividade; da fantasia onipotente de que ele não precisa do cuidado dos adultos. E. investe de muita raiva a imagem de seu pai, que ele desejava matar. Ele não consegue internalizar a figura do pai, e a concomitante função paterna, isto é, a aceitação dos limites e das regras, desenvolvendo uma atitude oposta, uma vida sem freios e contra os valores sociais. Encontra no tio alguém que cumpre duas funções, Ihe dá atenção e o apóia em seu modo de vida desregrado. 
Seus conflitos se apresentam, também, em uma área confusional do ego: "Ah! sei lá, não consigo pensar, quando penso, não calculo direito os pensamentos"

Parece que os mesmos traços marcantes de dependência, que o levam às drogas em um processo de auto-destruição, aparecem, também, como um elemento que o resgata desse mundo. E. afirma que o principal fator que o faz procurar a clínica para reabilitar-se foi a discriminação de seus familiares, o fato de estar sentindo-se só e abandonado, condição difícil de suportar para alguém com tendências de dependência tão acentuadas.

Por outro lado, esboça desejos de reparação e de relativização. Tem desejo de constituir família e reconciliar-se com a sua, ajudar seus amigos e responsabilizar-se por algo ou alguém, para poder ser reconhecido e desenvolver melhor sua auto-estima (que pode Ihe dar segurança e amor próprio). Tenta buscar o desenvolvimento e a maturação. Há,contudo, um desgaste da força vital, na tentativa de neutralizar os impulsos destrutivos e a desagregação. 
Sujeito F.

(masculino)

Heredograma

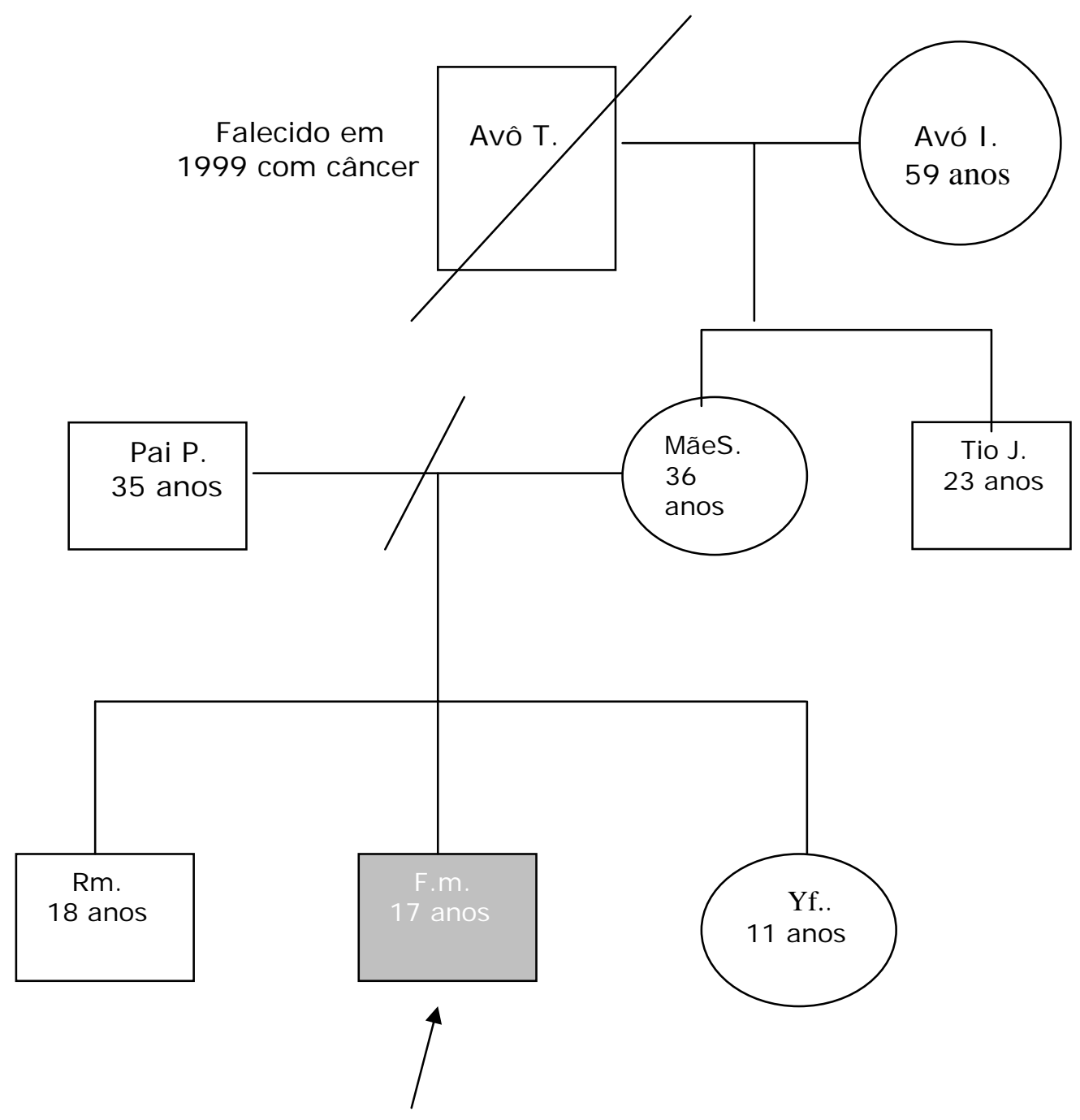




\section{Composição familiar}

A família de F. é constituída por sua mãe, sua avó, dois irmãos e um tio. A avó é de descendência russa e perdeu seu marido, em 1999.

A mãe de F. tem 36 anos e trabalha como ajudante de serviços gerais.

F. tem um irmão, um ano mais velho, R., que é borracheiro, mas está desempregado.

Tem uma irmã, seis anos mais nova, Y, com quem F. é bastante ligado.

Um tio, J, que trabalha como carteiro e tem 6 anos a mais que nosso sujeito. 


\section{RCUNSTÂNCIAS E FASES DO DESENVOLVI MENTO}

\section{Circunstâncias}

Nasce seu irmão R.

F. e sua família moram em Santos, mesma cidade, onde moravam seus bisavós.

Conta que seu pai bebia e batia na mulher e nos filhos

Migram para São Paulo e ficam

morando nas ruas.

Seus pais se separam

F. sua mãe e seu irmão R. vão morar com os avós que são imigrantes russos

F. nunca mais se encontra com o pai. Nasce sua irmã $Y$, filha de seus pais, que se encontravam mesmo após a separação.

Mudam de casa, indo morar em outro bairro

A partir desse episódio, as brigas se tornaram constantes, assim como aumentou muito o controle sobre seu comportamento.

Falece seu avô acometido de câncer.
SUJ EITO F.

(masc)

I dade/ ano

\section{Sujeito}

1985

1986

Nasce F. (sujeito)
2 anos

6 anos

7 anos

F. e um amigo com oito anos pegam carona em um trem cargueiro e vão para Santos, onde encontram os seus bisavós.

Interpreta esse controle como falta de amor e não como preocupação com sua segurança.

Conta que as brigas com seu irmão são freqüentes, que seu irmão não o respeita.

Briga, também, com seu tio, seis anos mais velho, pois esse toma conta da TV. F. já fugiu de casa várias vezes, indo morar na Praça da Sé. Alega que o motivo das fugas são as constantes brigas.

15 anos F. lamenta sua morte, dizendo que seu avô lhe dava muito carinho, "ele era um pai para mim" (sic). Diz, também, que sua avó lhe dá um pouco de carinho e que sua mãe não lhe dá carinho nenhum. F. completou a 7ạ série, ultrapassando seu irmão.

Teve três empregos: pedreiro, borracheiro e padeiro, onde ficou mais tempo, dois meses. Já experimentou maconha, mas não gostou. Atualmente, não usa drogas. 
17 anos Em sua última fuga, foi para a Praça da Sé, onde uma funcionária do SOS Criança, que já o conhecia, o encaminhou para a AMC.

Na época das entrevistas estava no abrigo havia três meses.

17 anos O Serviço Social da AMC o encaminhou para dois empregos, como office-boy. Foi demitido por alegação de furto. Os funcionários da AMC afirmam que ele tem o hábito de furtar objetos dos colegas.

F. conta de uma garota, por quem ficou apaixonado e a procura até hoje, ela também vive entre as ruas e os abrigos. F. conta que deseja ser jogador de futebol e, se não for possível, gostaria de ser médico ou enfermeiro para "ajudar as pessoas". 


\section{Resumo das entrevistas}

O sujeito, com 17 anos, tem um irmão, aproximadamente um ano e meio mais velho (18 anos), e uma irmã, seis anos mais nova ( 11 anos).

Morou com o pai, a mãe e o irmão na cidade de Santos (São Paulo), a mesma cidade onde moravam seus bisavós. Conta que seu pai bebia e batia na mulher e nos filhos. Com, aproximadamente, dois anos de idade, a família veio para São Paulo e ficaram morando nas ruas até que seus pais se separaram. Em seguida, a mãe e as crianças foram morar com os avós, por parte de mãe, que são imigrantes russos. Desde então, F. não vê o pai. Quando tinha seis anos, nasceu Yf., filha de seus pais que, se encontravam eventualmente.

Aos sete anos de idade, mudaram de residência, indo morar no bairro de Francisco Mourato. Nessa época, fez sua primeira fuga, ele, com sete anos, e mais um amigo, de oito anos, pegaram um trem cargueiro e foram parar em Santos. Lá procuraram os bisavós de F. que, segundo ele, os receberam bem. Após um mês e dois dias (sic), a pedido dos bisavós, voltaram para São Paulo, trazidos pelo Serviço Social da cidade de Santos.

F. relata que, a partir dessa fuga, as brigas em casa não pararam mais. Queixase que sua avó e sua mãe não o deixam sair para se divertir, enquanto seu irmão sai a hora que quer e até enfrenta a avó, dizendo que vai sair para fumar maconha. F. acha que o bairro em que mora é tranqüilo e, por isso, não interpreta a interdição como um cuidado, mas acha que ela é feita porque "eles não gostam de mim".

Conta que sua mãe não the dá carinho, sua avó lhe dá um pouco de carinho e seu avô, que faleceu há 2 anos, com câncer, Ihe dava muito carinho: "Ele era um pai para mim". F. sentiu uma grande "perda" (sic) com o seu falecimento. Diz que seu avô lhe deixou o exemplo de ser honesto na vida e, sua avó, o exemplo de não maltratar ninguém. Conta que sua mãe é muito brava e nervosa. Gostaria muito de não depender da mãe e da avó. Diz que sua família é bastante religiosa.

Conta que as brigas com seu irmão são constantes - diz que enquanto ele pede alguma roupa emprestada para seu irmão, este pega as roupas de $\mathbf{F}$., sem pedir licença. Afirma que seu irmão briga até com sua irmã, de 11 anos, já, ele próprio, se dá bem com a irmã. As brigas acontecem, também, com seu tio, que 
usa a TV para jogar videogame e se apodera do aparelho, não deixando mais ninguém usá-lo. Em outro momento, reconhece que ele próprio é muito impulsivo e fica agressivo com facilidade.

Seu tio trabalha como carteiro, sua mãe é ajudante geral, seu irmão borracheiro, mas, no momento, está desempregado e F. já teve 3 empregos, começando por pedreiro, depois borracheiro e, finalmente, padeiro, ocupação em que ficou mais tempo empregado, dois meses. F. conta que está na 7ạ série, e que já ultrapassou seu irmão nos estudos.

Já saiu várias vezes de casa, indo para a praça da Sé e freqüentando outros abrigos, alegando sempre que as razões de suas fugas são as brigas em casa. Na ultima fuga, educadores do Projeto Travessia o encaminharam da Praça da Sé para a AMC., abrigo que ele já conhecia.

Conta que já experimentou maconha, mas não gostou, e que não faz uso de drogas.

Fez um grande amigo, quando se mudou para Francisco Mourato, tem boas lembranças do companheiro e diz que nunca brigaram. F. declara-se "esquentado", briga por qualquer coisa, mas nunca brigou com N., esse amigo. Diz que ele é calmo, "cabeça feita", trabalha, estuda, não usa drogas, vai à I greja e sempre aconselha F. a não fugir de casa. Diz que N. quer ser médico. F. diz que gostaria de ser jogador de futebol e, se não der, quer tentar ser médico ou enfermeiro "pra ajudar as pessoas".

Aos 18 anos, quando tiver que deixar o abrigo, quer alugar um quarto com mais dois amigos; um deles trabalha e o outro, está procurando emprego. F. diz que só vai arrumar um bom emprego, depois que resolver a sua situação militar. No momento, espera a próxima semana para começar, como Office-boy.

Em dois empregos anteriores, arranjados pelo serviço social da AMC, foi acusado de roubar dinheiro, $\mathrm{R} \$ 50,00$ em um trabalho, do qual foi demitido e, depois, $R \$$ 10,00 do outro. Esses valores foram descontados do seu pagamento. F. confidenciou que rouba coisas pequenas, mas que não gosta de roubar e que já foi convidado, várias vezes, para ir roubar no farol, com outros garotos, e não aceitou. A assistente social contou que ele tem o hábito de tirar coisas dos garotos do abrigo e que estas são encontradas, depois, em seu armário.

F. se diz apaixonado por uma garota, $P$, de quem se desencontrou há três meses. Pergunta sempre sobre ela para os meninos que chegam e diz ter 
certeza que ela gosta dele, também. No momento, diz ter um 'caso' com uma menina, mas que ela está indecisa. Conta que a melhor coisa em P. é o seu beijo e fala que, quando está namorando, é o "homem mais feliz do mundo". Não gosta da solidão.

\section{Observações}

F. é um jovem bem desenvolvido, fisicamente, com boa estatura e constituição física, aparentando boa saúde. Quando conversamos, demonstrou timidez. Observando seu comportamento na casa, parece ser uma pessoa introvertida e que se mantém isolada dos companheiros.

As entrevistas foram realizadas na AMC e, por ser período próximo ao final do ano, F. dispunha de tempo, pois não estava estudando, nem trabalhando. Dessa forma, em, aproximadamente, três semanas, colhemos todas as informações.

Durante os encontros, ele demonstrou estar deprimido, queixando-se das constantes brigas com seu irmão que, segundo ele, são o motivo de suas fugas. F. foi cooperativo nas entrevistas, embora não tenha se alongado nas conversas. Quanto ao aspecto cognitivo, demonstra capacidade dentro da média para sua idade, considerando-se que seu rendimento escolar, ele está na sétima série, corresponde ao esperado para a sua idade.

Do ponto de vista emocional, nota-se certo prejuízo na esfera sócio-afetiva, com comportamentos de isolamento em relação aos companheiros; dificuldades trazidas pelo problema com os roubos. Percebe-se em F. uma expressão de "bebê chorão", mesclada com um olhar esquivo, com sinais de hipervigilância.

\section{Resultado dos testes}

\section{HTP}

A análise dos desenhos indica:

$>$ um estado emocional deprimido.

> Utiliza o pensamento de forma mais concreta, com pouca capacidade de abstração, simbolização e generalização. 
> Uso intenso da idealização e da cisão, como defesas.

$>$ Nota-se nos desenhos um sentimento de vazio interno.

> Necessidade de contato pessoal, porém, de forma vazia, destituída de afeto.

> Sentimentos de não aceitação do meio, atitudes de oposição.

> O sujeito demonstra possuir bons recursos egóicos.

\section{TAT}

A interpretação das estórias sugere:

$>$ O sujeito apresenta fortes sentimentos de agressividade e tendências à impulsividade.

> Demonstra a presença de intensos sentimentos de culpa e comportamentos de auto-punição, além de um estado de humor depressivo.

> O sujeito parece justificar sua própria agressividade, como uma resposta em defesa às agressões que partiram, inicialmente, do meio externo.

$>$ Demonstra alguma dificuldade em simbolizar.

> Parece esperar que as coisas se resolvam sozinhas, não encontrando, em si, os recursos ou a discriminação, de que ele tem de agir para mudá-las.

> Tendências à idealização e absolutização.

\section{I nterpretação dos dados}

O sujeito e seu irmão, com apenas um ano e meio de diferença de idade entre eles, tiveram uma circunstância desfavorável para seu desenvolvimento, já que seu pai era alcoólatra e batia na mulher e nos filhos. Segundo MELANIE KLEIN (1971; 1982), situações de frustração intensa e persistente podem aumentar a hostilidade e a voracidade de um indivíduo. Podemos pensar, a título de hipótese, que a mãe de nosso sujeito, que poderia estar sentindo a falta de atenção, acolhimento e respeito, por parte do marido, em tal circunstância não poderia oferecer aos filhos o que a ela estava faltando. É possível que a proximidade com os bisavós possa ter ajudado, como um ponto de apoio e referência para a família, nos tempos em que viveram em Santos. Parece que F. 
os "internalizou como objetos bons", pois foi para a casa deles que ele foi, quando saiu de sua casa, aos oito anos de idade.

O irmão mais velho de $\mathbf{F}$. tem apenas um ano e meio de diferença, o que deve ter dividido a atenção da mãe, quando F. nasceu, subtraindo de R. boa parte dos cuidados e atenção que ele desejava, hipótese que poderia explicar a rivalidade entre os dois irmãos.

A família de F., que migrou para São Paulo, quando ele ainda tinha dois anos de vida, precisou ir morar nas ruas, pois a avó materna de nosso sujeito não aceitava seu genro. Somente com a separação entre os pais de F. é que eles puderam mudar-se para a casa de seus avós, saindo das ruas. Encontramos, aqui, mais uma circunstância estressante, podendo ser considerada como de forte potencial negativo para o desenvolvimento das crianças.

Mesmo após a separação, os pais de $\mathbf{F}$. se encontravam eventualmente, e um dos resultados desses encontros foi o nascimento de $Y$, irmã de F., quando ele estava com seis anos de idade.

O fato de F. ir procurar seus bisavós, saindo de casa, por conta própria, aos sete anos, pode indicar que ele esperava encontrar uma situação melhor, mais gratificante do que a que estava vivendo. Provavelmente, uma situação idealizada, como vimos ser uma constante no conjunto dos dados obtidos. Ele afirma que, depois desse episódio, começaram as brigas dentro de casa. Ao nosso ver, essas brigas poderiam ser desencadeadas por uma tentativa de conter o comportamento impulsivo de $\mathbf{F}$.

De acordo com F., sua família não o deixa fazer nada do que ele gostaria, como ir às festas e sair com os amigos. Sua compreensão dessa circunstância é de que sua mãe e sua avó "fazem isso por que não gostam de mim". As limitações impostas a um individuo, que não tolera frustrações, nem adiamentos, provocam sentimentos de raiva e de privação, que são interpretados como manifestação de desamor. Sujeitos pouco amadurecidos, com uma compreensão restrita e absolutizada dos fatos, não são capazes de perceber um aspecto de cuidado, por parte da família, nas interdições impostas para preservá-lo.

Seria interessante investigar os efeitos, sobre nosso sujeito, da interação entre duas culturas, aparentemente, tão diferentes, como a russa e a brasileira. Os bisavós maternos são migrantes russos, sendo que a avó materna e sua mãe foram criadas dentro de diferentes padrões culturais. Segundo F., a família é praticante da religião católica (provavelmente, o catolicismo ortodoxo). 
Do ponto de vista psicodinâmico, F. apresenta um funcionamento mental regido, predominantemente, pelo processo primário (menos evoluído). Esta afirmação se apóia em mecanismos, como: os aspectos agressivos de F. estão colocados (projetados), principalmente, no irmão, e a reconciliação entre eles depende, também, somente do irmão, pois F. "em nada contribui" (sic) para a formação das brigas, isto é, ele não demonstra qualquer sentimento de responsabilidade pelos desentendimentos, o que o torna a vítima da situação; para ele, há duas formas de sentir, opostas e absolutas - "quando estou namorando, sou o homem mais feliz do mundo" e por outro lado "ninguém gosta de mim", que the confere um ar infantil de 'bebê chorão'; como, também, o emprego de defesas, como a idealização observada na fantasia de que as relações familiares ou amorosas representam a felicidade absoluta e; a presença marcante de ambivalência: sentimentos de amor e forte rejeição que se alternam, em relação aos mesmos objetos, por motivações inconscientes.

WINNICOTT (2002) afirma que os furtos dos adolescentes podem ser interpretados como reação à perda de algo bom (afeto, atenção, etc...) e que o jovem busca recuperar, através dos furtos.

Por outro lado, F. esboça desejos de reparação e de relativização. Deseja ser jogador de futebol "mas, se não der, quer ser médico para ajudar os outros". 

Sujeito P.

(feminino)

Heredograma

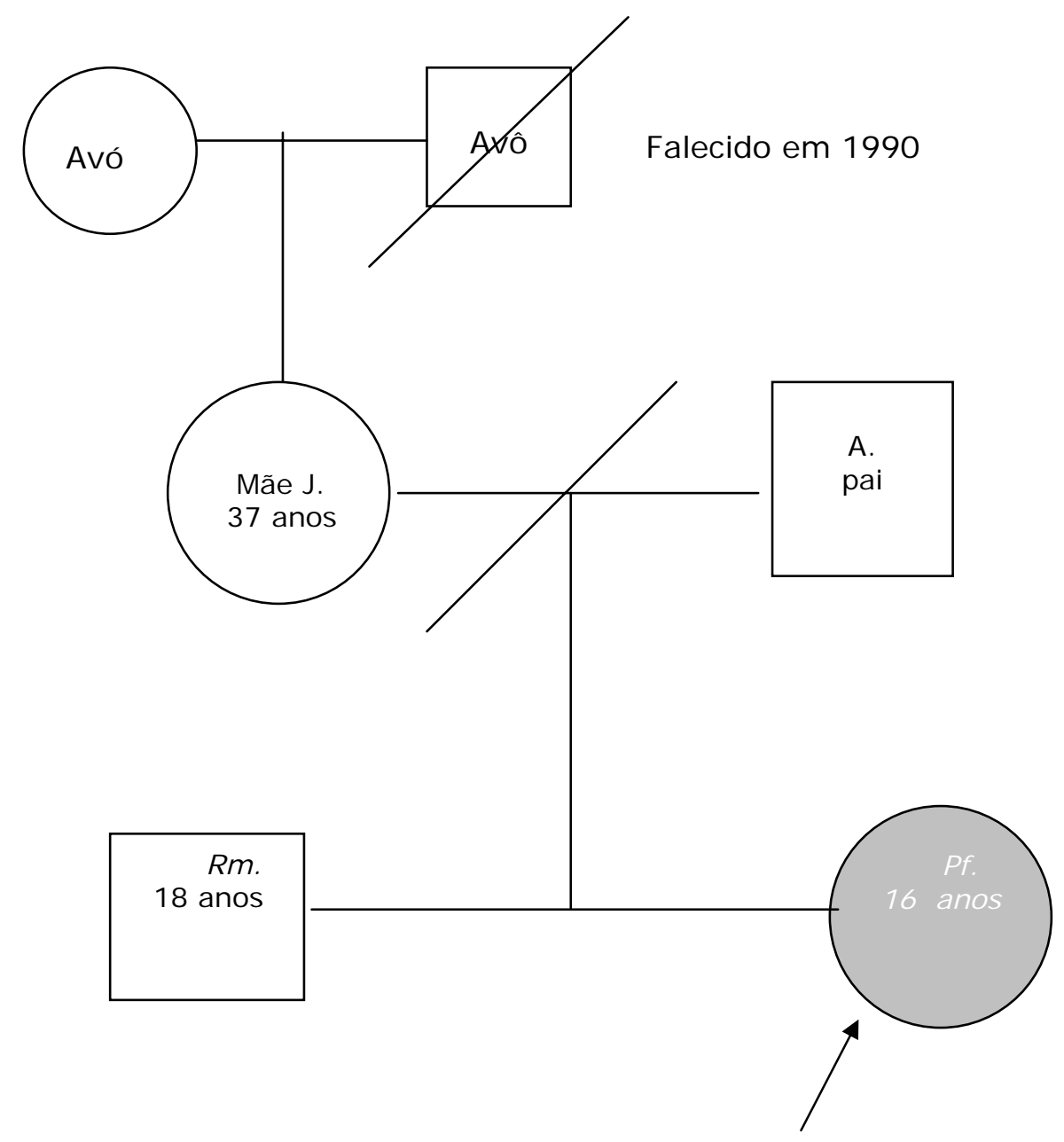




\section{Composição familiar}

A família de Pf. é constituída de:

Avó, que mora em uma pensão no Brás e cuida de seu irmão, desde que era recém-nascido.

Mãe, com 37 anos de idade, atualmente trabalhando em uma lanchonete e morando com a avó de Pf.

Irmão R., que tem 18 anos, não trabalha, é viciado em drogas e encontra-se em Liberdade Assistida. 
CI RCUNSTÂNCIAS E FASES DO DESENVOLVI MENTO

\author{
Circunstâncias
}

Nasce R. (irmão) que fica sob a guarda da avó, desde os cinco dias de vida.

O pai de Pf é assassinado, por motivo de dívidas.

"Logo em seguida" (sic) a mãe passa a morar (em união consensual) com uma mulher, K. (policial).

A mãe de Pf. requer a guarda da filha, que passa a morar com a mãe e $\mathrm{K}$. As relações, que eram boas, no início, passam a ficar tensas.

Pf. presencia uma cena de troca de afetos entre $K$. e sua mãe, fato que a revolta.

Em outra ocasião, vê uma amiga da família trocando carícias com sua mãe.

Pf. conta o que viu para K., mas sua mãe desmente Pf.

Sua mãe disse que não aceitaria a gravidez e que ela deveria abortar se quisesse voltar para casa.

Sua mãe e K. contrataram os serviços de um"macumbeiro", que foi à sua casa, Ihe deu chás e batia em seu ventre para provocar o aborto

\section{Sujeito \\ P. (fem)}

I dade/ ano

Sujeito

1985

1987 Nasce Pf. (sujeito)

3 anos Pf. é deixada sob a guarda da ex-patroa de sua mãe, D.

Relaciona-se bem com a família, estuda, tem amigos na escola e na vizinhança.

Bom vínculo afetivo com D., mulher que a acolheu.

10 anos

Pf. queixa-se de K., que cobrava muito nos estudos e na limpeza da casa, não a deixando divertir-se. Reclama, também, que sua mãe não intercedia a seu favor

13 anos Primeira fuga. Pf. Vai de carona até a cidade de Santos e chegando lá, com medo, telefona para a mãe ir busca-la.

Nessa época as fugas tornaram-se constantes.

14 anos Ficou grávida de um rapaz de 18 anos, traficante, ciumento e violento. Conta que apanhava dele e da irmã dele.

Pf., que queria o filho, inicialmente conta: "não sei o que aconteceu que, de um dia para o outro, me revoltei e falei que não queria mais o filho".

Durante o encontro com esse homem, saiu de casa, fugindo da situação e encontrou a irmã de seu namorado, que bateu nela com um pedaço de pau o que acabou provocando o aborto. 


\section{Circunstâncias}

Ganha da mãe uma festa de aniversário. No dia seguinte, $\mathrm{K}$. bate em Pf., que não compreende o motivo de ter apanhado.

Mãe separa-se de K. e está "namorando um homem" (sic). Pf. diz que sua mãe mudou muito, que passou a dar atenção aos filhos e quer alugar uma casa para que todos morem juntos.

A mãe trabalha em uma lanchonete.

\section{Sujeito}

15 anos

Pf. passa a procurar abrigo na casa de parentes e amigos, que não a acolheram. Em certa ocasião, telefona da rua para a mãe pedindo ajuda e essa responde que ela havia escolhido aquela vida e que não contasse mais com seu apoio.

15 anos "Cansada e com medo das ruas" foi a um Posto Policial, que a encaminhou para o Projeto Taiquara, onde brigou com uma menina e, com medo de ser encaminhada para a FEBEM, foge.

Viveu nas ruas próximas da Praça Marechal Deodoro, com um grupo de jovens

Não comia e passava a maior parte do tempo cheirando cola.

Ficou anêmica e foi hospitalizada.

16 anos Concluiu a 7ạ série e deve terminar o primeiro grau, em seguida.

Ao ser entrevistada, estava há três meses na AMC., para onde foi encaminhada pelo projeto Criança Cidadã.

Ela afirma que não está usando drogas no momento. 


\section{Resumo das entrevistas}

Pf. tem 16 anos de idade e um irmão de 18. Seu pai foi assassinado, quando ela tinha 3 anos de idade. Ela conta que se lembra da apreensão de sua mãe, que chorava com freqüência, e das repetidas vezes que seu pai introduzia nas conversas: - "Olhem, meus filhos, se um dia eu morrer eu quero...". Mais tarde, Pf. soube que ele estava ameaçado de morte por motivo de dívidas. Após a morte, sua mãe pediu que a senhora para quem ela trabalhava, cuidasse da menina e assim Pf. morou com dona D. até seus 10 anos de idade, quando sua mãe pediu, em Juízo, para ter novamente a guarda de Pf..

Pf. tinha bom relacionamento com dona D., a quem chamava de 'vó'; com o filho de dona D., que se tornou seu padrinho e; mais um parente de D., que morreu aos sete ou oito anos de idade. Pf. conta que ficou dias sem comer e que, na ocasião do enterro, queria entrar na cova do garoto. Teve muitos amigos na sua infância, entre seus vizinhos e colegas de escola.

Seu irmão R. é usuário de drogas, não trabalha e mora com sua avó desde os 5 dias de nascido.

Pf. está na AMC há três meses e veio encaminhada pelo Projeto Criança Cidadã. Conta que estava na Praça Marechal, aproximadamente, há um ano e meio, que praticamente não comia e passava a maior parte do dia cheirando cola, até desenvolver uma anemia grave. Foi encaminhada para um hospital e ficou tomando soro por dois dias. Conta que ela e os amigos passavam o dia todo cheirando e só comiam quando pediam, ou às sextas-feiras, quando alguns voluntários iam levar comida, à noite, para os moradores de rua e que havia dias que não conseguia dormir de 'tanta fome'.

Durante 10 meses que passou na praça, a turma era a mesma, cinco meninas e quatro meninos, com o tempo, alguns foram se afastando e ficaram apenas Pf. e outras três pessoas. Conta que por lá apareciam dois rapazes, um de 20 e outro de 23, que protegiam as meninas. Eles estavam em liberdade condicional, prestando serviço comunitário e, depois do trabalho, passavam no local onde elas moravam, às vezes trazendo alimentos ou roupas e, por vezes, dormindo no local para protegê-las de pessoas que desejavam abusar sexualmente das garotas. 
Sobre o uso da cola, Pf. conta que parte dos efeitos são muito desagradáveis: surge, inicialmente, uma sensação de sufocamento, em seguida, tontura e, muitas vezes, grande rebaixamento da consciência, com perda de memória. Perguntada sobre o lado 'bom', ela responde: “Porque tinha muitas vezes que eu ficava sentida, porque eu não queria me desentender com minha mãe, e para esquecer tudo isso, eu ficava cheirando cola".

Pf. conta que, antes da Praça Marechal, ela estava no Projeto Taiquara, onde brigou com uma menina e a machucou. Com medo de ser encaminhada para a FEBEM, fugiu e foi parar na Praça da Sé, onde encontrou G., menina que havia morado na casa dela e esta a chamou para ir para a 'Marechal', onde ela tinha amigos. Pf. foi parar no Projeto Taiquara, porque havia fugido de casa, e estava na rua há algum tempo, certa noite foi a um posto policial e pediu que a encaminhassem para algum lugar, pois não queria mais ficar na rua.

Pf. alega que fugiu de casa, por causa dos desentendimentos entre ela e a namorada de sua mãe. Segundo suas informações, sua mãe juntou-se com uma mulher chamada K., policial de profissão, e passou a viver com ela, logo após a morte de seu marido. Logo que ela voltou a morar com a mãe, aos 10 anos de idade, as relações entre as três eram boas. Perto dos seus 13 anos de idade, as relações dentro de casa tornaram-se tensas pois, segundo ela, K. passou a ser exigente e rigorosa com Pf., cobrando que ela estudasse e ajudasse na casa, sem direito à diversão. Pf. queixa que sua mãe não intercedia a seu favor, sempre dando razão à sua companheira. Aos 13 anos, desobedeceu K. e este fato gerou uma briga com sua mãe, que provocou a primeira fuga. Ela foi de carona para Santos, chegando lá, ficou com medo e telefonou, pedindo para a mãe ir buscá-la. A partir daí, as fugas tornaram-se constantes, mas ela sempre voltava para casa.

Certa vez, no aniversário de sua mãe, Pf. conta que K. trouxe alguns presentes e três CDs de música e que as duas se trancaram no quarto. Pf., que queria descer para brincar, e não queria mais esperar, foi olhar pelo buraco da fechadura e viu as duas se beijando, o que Ihe causou nojo da mãe. Em outra ocasião, ela viu uma outra amiga de sua mãe acariciando-a, enquanto ela fazia o almoço. Pf. afirma que xingou a mulher e, depois, contou para K., fato que sua mãe desmentiu.

Pf. conta que, quando fez 15 anos, sua mãe lhe deu uma festa e que, no dia seguinte, sem ela entender por quê, K. Ihe bateu. Pf. saiu de casa e passou a 
buscar apoio na casa de amigos e parentes, que não quiseram acolhê-la. Conta que telefonou para sua mãe e esta respondeu que ela havia escolhido a rua, por vontade própria, e que então ela não voltasse mais para casa. Esse foi o início da vida de Pf. nas ruas.

A mãe de Pf. separou-se de K., há aproximadamente 8 meses, por motivo de traição de K.. Pf. conta que sua mãe mudou completamente depois disso, tornando-se mais carinhosa, "ela não pensa só nela e na mulher, ela tá namorando com um cara agora, mas ela pensa primeiro nos filhos dela, para depois pensar no cara".

Pf. conta que J., sua mãe, que trabalha em uma lanchonete, alega que tem intenção de alugar uma casa e levar seus filhos para morar com ela, mas R. o irmão de Pf. já avisou que não vai, que irá continuar com a avó. No momento, J. está morando na pensão, com a avó de Pf. e seu filho R.m., mas o lugar é muito pequeno para acomodar também a Pf. Nosso sujeito afirma que: "eu sempre quis morar com minha mãe, depois, se não fosse por essa mulher, eu não tinha nem fugido de casa, não sabia nem o que era a rua". Pf. reclama que sua mãe dava mais atenção para sua companheira do que para ela. Afirma que seu irmão foi morar com elas, certa vez, mas que $K$. começou a tratá-lo mal e ele voltou para a casa da avó. Em outro momento, Pf. conta que K. tinha muito ciúme dela com a mãe.

Pf. afirma que estudou até a sétima série e que, este ano, deve terminar o primeiro grau.

Conta que namora homens e não sente atração por meninas. Que seu primeiro namorado era traficante de drogas e batia muito nela. Ela engravidou desse rapaz, quando tinha 14 anos de idade, e ele estava com 18 anos. Sua mãe falou que era para ela escolher, ou ia morar com o namorado, ou ia para a rua, que na casa dela ela não ia ficar. A mãe queria que ela abortasse, enquanto Pf. queria ter o filho. Sua mãe pediu para um "macumbeiro" fazer um trabalho e passaram a insistir para que ela tomasse um chá, feito com maconha, o qual ela recusava - "nisso eu não sei o que aconteceu, de um dia pro outro, eu me revoltei e falei que não queria o filho". Nesse dia, o macumbeiro, sabendo que ela tinha mudado de opinião, foi à sua casa e começou a lhe dar um chá que a fazia vomitar, dava-Ihe socos na barriga e nada acontecia. Então Pf. saiu para rua e foi procurar o seu namorado, contando-lhe tudo. Seu namorado disse que assumiria o filho e que ela passaria a morar na casa dele. Nesse ínterim, a mãe 
de Pf. foi procurá-la. Sabendo disso, Pf. fugiu, sem avisar ninguém, e encontrou com a irmã de seu namorado na rua. Como Pf. tinha ordens de não sair de casa, sua cunhada bateu muito nela, inclusive, com um pedaço de pau, um dos golpes foi na barriga, provocando o aborto.

Sobre seu pai, que era borracheiro, ela conta que era muito apegada a ele, que ele a defendia, que quando sua mãe saía aos sábados, à noite, para ir dançar, deixando-a em casa sozinha com o irmão, ainda em época de mamar ao peito, o pai ia buscar a mulher no salão e batia nela, pelo descuido com os filhos. Diz que ele a colocava no colo e falava assim: "Filha, eu sei que tudo o que você viu agora, quando for mais tarde, quando você for mais velha, você vai lembrar, mas o que o pai fez com a mãe, agora, foi porque ela deixou vocês chorando (...). Se um dia o pai morrer, quando você estiver sofrendo, eu sempre vou estar do seu lado, sempre vou aliviar um pouco o seu coração, pra você parar de sofrer. Sempre quando eu choro, assim, eu lembro das coisas que ele falou e "ou eu pego no sono ou eu paro de chorar". Pf. conta que seu pai sempre se referia à sua própria morte e sua mãe chorava, sozinha, com muita freqüência. Já mais velha, a mãe de Pf. contou que seu pai devia dinheiro e que os credores avisaram que matariam a ele, ou alguém da sua família.

Em outro momento, Pf. dá um depoimento contraditório. Perguntada novamente sobre o relacionamento dos pais, ela diz: "Eles raramente brigavam, era raro eles brigar, então meu pai não podia ver eu chorando que ele vinha e ficava me agradando; os dois raramente brigavam, ficavam num clima bom, assim, sabe, minha mãe cuidando de mim e de meu irmão, ele ia trabalhar, voltava e ajudava minha mãe cuidar de nós". Pf. diz que, sobre sua mãe, ela não se lembra de nada. Que sua mãe conta que ela é muito parecida com o pai, decidida e encrenqueira e que ela tem várias qualidades que seu pai tinha, como ser sentimental, isto é, se ela briga com alguém, logo em seguida, começa a chorar. Diz que se apega, com muita facilidade, a pessoas. "Meu pai era assim, ele gostava de ajudar bastante gente e eu, por mais que eu não tinha nada, deixava de comer prá dar para os outros".

Pf. descreve sua mãe como uma pessoa que aparenta ser arrogante e fechada e que, embora seja carinhosa, não gosta de demonstrar, - "a minha mãe quer chegar em nós, quer fazer um carinho, só que ela tem medo de fazer e, depois, a gente pegar e dar mancada com ela". Diz que sua mãe lhe ensinou a se prevenir contra doenças sexuais, que elas conversavam muito sobre namorado, sexo, doença e prevenção, que isso foi o que sua mãe lhe deixou de bom. Conta 
que as duas saíam para os bailes e ficavam dançando, "parecia que a gente sempre teve aquele amor uma pela outra, só que era só na festa, chegava em casa, a coisa mudava, parecia que ela só queria mostrar que estava feliz assim, perto da gente, porque as amigas dela estavam ali."

Pf. afirma que sua mãe mudava muito de humor, que ficava triste por dias, fechada e chorando, e não falava nada sobre o assunto e que havia outros dias, em que ela ficava muito feliz, que as duas saíam e conversavam muito, relata que sua mãe sempre a ajudou nos estudos, que seu desejo é o de se formar em pediatria.

V. é uma das amigas da mãe de Pf., com quem ela se entende muito bem; esta mulher acolheu Pf., por várias vezes.

Refere que nunca teve doença importante, mas que seu irmão sempre apresenta crises de falta de ar, chegando a ser hospitalizado; "de tanto fumar maconha", interpreta Pf.. Seu irmão está em L.A. (liberdade assistida).

Ela conta que não está usando drogas no momento. Revela o nome dos educadores e abrigados da AMC com quem ela se dá bem. Manifesta que se sente acolhida neste abrigo, e que ele é diferente de outros que ela conheceu, onde a disciplina era muito rígida, proibindo-se o cigarro, as saídas, obrigando o uso da 'roupa da casa', enfim não dando espaço para a individualidade dos abrigados.

\section{Observações}

Pf. foi a última adolescente a ser entrevistada, portanto, já estava a par deste trabalho e, quando foi convidada a participar, aceitou sem hesitação. Está abrigada na AMC há 3 meses, é uma moça bonita e sempre que estivemos juntos demonstrou jovialidade e cooperação. Tem um jeito pueril na sua maneira de falar e gesticular, expressando-se bem, tanto na comunicação verbal, como não-verbal. Pareceu-nos bem adaptada à casa e relatou ter bom relacionamento social. 
Aparenta desenvolvimento geral adequado, indicando boas condições de saúde. Quanto ao desenvolvimento cognitivo, encontra-se dentro da média das realizações esperadas para sua idade, levando-se em conta o rendimento escolar. Nota-se certo atraso em seu desenvolvimento emocional, observado em alguns aspectos de sua personalidade.

\section{Resultado dos testes}

\section{HTP}

A análise dos desenhos sugere:

> Uso intenso de mecanismos obsessivos.

> Fraca discriminação entre realidade interna e externa.

$>$ Tendência a fantasiar para defender-se do contato com a realidade.

$>$ Dificuldades para definir identidade sexual.

$>$ Introjeção de objetos bons.

TAT

A análise das respostas sugere:

> Sentimentos depressivos.

$>$ O sujeito sente-se oprimido e perseguido pelo ambiente externo.

> Sentimentos de incompreensão.

$>$ O sujeito encontra recursos internos para enfrentar as exigências da vida. 
Suspeitamos que há, nesse caso, possíveis dificuldades, por parte da mãe, quanto a definição de identidade sexual e em assunção do seu papel de mãe. Inicialmente, partimos de um fato, que precisaria ser devidamente esclarecido, mas que pode indicar um sentido para nossa reflexão: a mãe de Pf. passa a guarda de seu primeiro filho, recém-nascido, à sua mãe. Outro elemento a ser considerado é que diante da morte do marido, J., a mãe de Pf., pede que sua ex-patroa crie sua filha, que, na época, tinha dois anos de idade e, logo a seguir, passa a viver uma ligação homossexual. Segundo informações de Pf., a mãe gostava de sair para divertir-se nos bailes, deixando os filhos pequenos, ainda de colo, sob os cuidados do pai. À época, a mãe de Pf. era bastante jovem, deveria ter em torno de 22 anos.

Outro fato relevante, para a compreensão do Potencial Circunstancial, em etapa de vida precoce de nosso sujeito, diz respeito às ameaças de morte dirigidas à seu pai, gerando tensão e angústia para toda a família e também para Pf que dizia que o pai sempre repetia: "quando eu morrer, eu estarei no céu, olhando por você", despertando nela o medo de perde-lo.

Se é possível pensarmos que Pf., em seu relato sobre sua puberdade e adolescência, aponta para inseguranças e confusões, podemos pensar que R., seu irmão, apenas dois anos mais velho (18 anos) apresenta também traços imaturos de comportamento: não trabalha, não estuda, está em condição de Liberdade Assistida e é usuário de drogas. Estes fatos, junto aos anteriores, podem indicar dificuldades experimentadas por ambos nos primeiros anos de vida.

Após os três anos de idade, quando passou aos cuidados de outra família, com quem permaneceu até seus 10 anos, parece ter encontrado um ambiente mais favorável para o seu desenvolvimento geral. Nesta nova casa, sentiu-se acolhida, tendo suas necessidades afetivas, educacionais, de saúde e lazer atendidas. Pf. estabeleceu fortes vínculos com D., a quem procurou, em vários momentos de dificuldades.

As lembranças do pai trazem a imagem de alguém carinhoso e cuidadoso. Conta que se recorda dele dizendo que estaria, mesmo depois de morto, sempre por 
perto para protegê-la . Pf. relata que, quando está assustada, lembra-se do pai e, então, se acalma ou adormece.

É interessante observar que, o retorno à casa da mãe parece re-atualizar antigas angústias, relacionadas à insegurança quanto ao afeto materno, expressas na disputa com K. pelas atenções da mãe e nas tentativas de separar o casal. Esses conflitos acabam sendo agravados com a chegada da adolescência e, aparentemente, não puderam ser acolhidos por sua família. Pf. sai de casa e busca apoio na casa de parentes e amigos, que, segundo ela, não se dispuseram a ajudar.

No decorrer dessas circunstâncias, Pf. assume uma atitude auto-destrutiva, de abandono de si mesma, passando a morar nas ruas, deixando de se alimentar e abusando das drogas a ponto de ser hospitalizada.

Pf. em nenhum momento reconhece e se responsabiliza por aspectos hostis e intolerantes de sua personalidade - responsabiliza sempre os outros pelos conflitos vividos - indicando um padrão na assunção do papel de vítima. Isto junto ao nítido e freqüente uso da idealização, emergente na expectativa expressa na frase: "e tudo vai acabar bem" (TAT), leva-nos a uma hipótese de um ego pouco integrado, frágil diante das dificuldades da vida.

Finalizando, podemos considerar que o Potencial Circunstancial inicial de vida do nosso sujeito não favoreceu o desenvolvimento de um ego bem estruturado. Entretanto, Pf. pode internalizar "bons objetos", perceptíveis em sua ligação com D., na lembrança de seu pai e no desejo de juntar-se à sua mãe, fornecendo sentimentos de esperança, o desejo de ajudar os outros (quer ser médica), além do desejo de constituir uma família. 


\section{Sujeito Pm.}

(masculino)

Heredograma

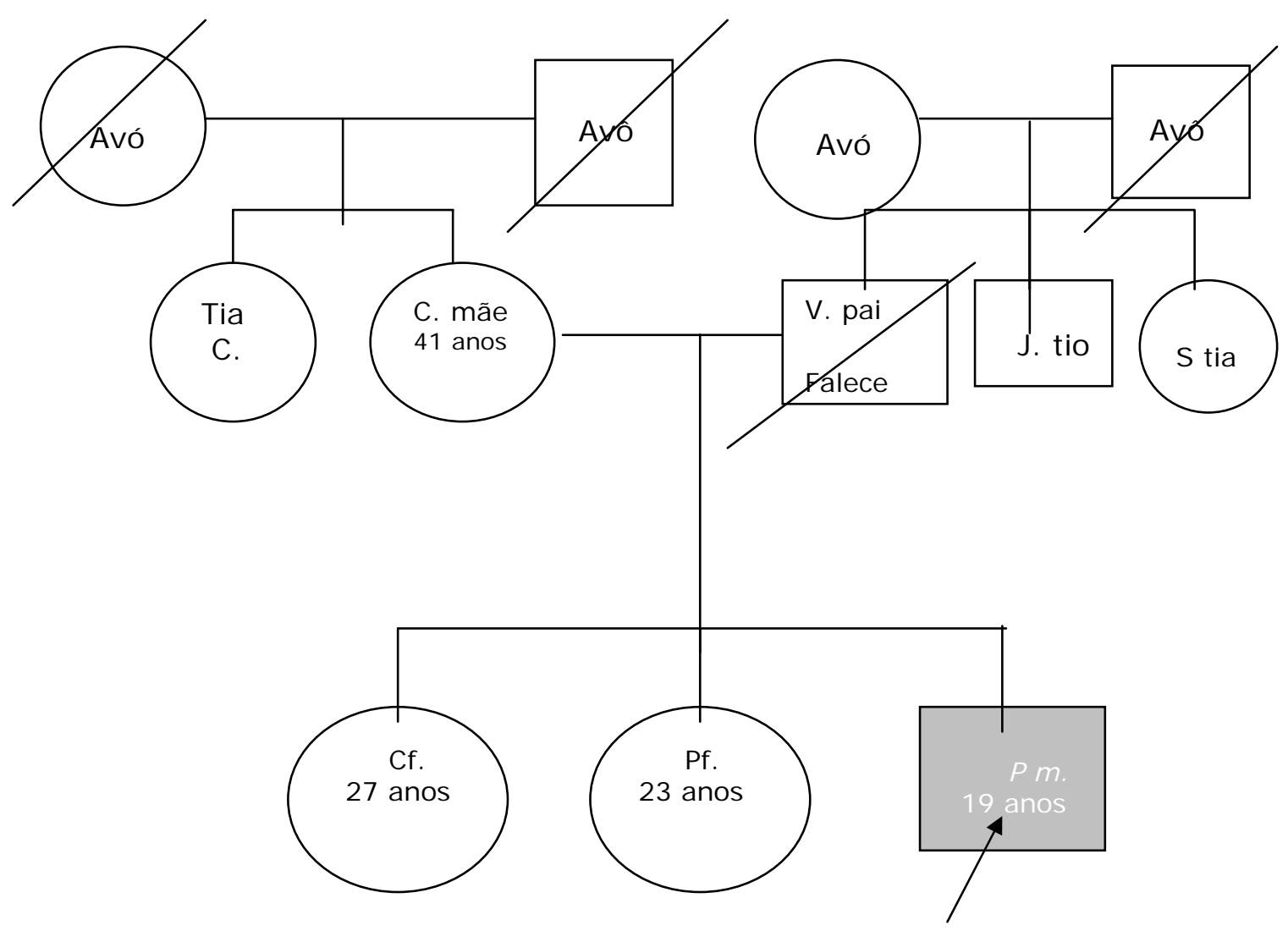

\section{Composição familiar}

C. mãe, com 41 anos de idade, mora no bairro do Taboão da Serra, mas Pm. nunca mais a viu desde a data do abandono. 
Pf. irmã, que fugiu de casa em 1994, Pm. nunca mais soube dela.

Cf. irmã, com 27 anos, há dois anos que não a vê. 


\section{RCUNSTÂNCI AS E FASES DO DESENVOLVI MENTO}

\section{Sujeito Pm. \\ (masc)}

Circunstâncias

Nasce Cf. (irmã), sua mãe tinha 14

anos.

Nasce Pf. (irmã)

Pai de Pm. é preso, pouco antes dele nascer.

Sua mãe tinha 22 anos de idade.

Sua mãe abandona a casa deixando os filhos aos cuidados de C., com dez anos de idade.

Após três meses (sic), sua tia C2 levou as crianças para sua casa. Pm diz que ela era alcoólatra.

Seu pai morre na prisão, vítima de doença cardíaca.

Poucos meses depois, vai morar em Osasco, com sua avó, onde fica por dois anos.

Mudam-se para Catanduva, Pm, sua avó, sua tia $S$, o tio $A$ e as primas $A$. com cinco, $\mathrm{M}$ com dez e $\mathrm{D}$ com dois anos de idade.

Seus tios voltam para São Paulo, mas deixam M. em Catanduva

Sua prima M. volta para SP.

Falece sua avó e Pm vem morar na casa de seu tio J., onde fica por quatro meses, voltando, em seguida, para a casa de sua tia C2. Lá reencontra suas irmãs. A irmã Pf. "muito briguenta" foge de casa, quatro meses após sua chegada e Pm. nunca mais a viu. C2 cobrava que Pm fosse honesto, estudasse e trabalhasse.
I dade/ ano

Sujeito

1976

1980

1984

1984 Nasce Pm. (sujeito) com problema cardíaco, trata-se e se diz curado.

2 anos

Visita seu pai na prisão por duas vezes, fato que o impressiona positivamente.

3 anos

Lembra que seu tio J foi como um pai para ele.

5 anos Brinca com sua irmã Cf. (13 anos de idade), dizendo que ia matá-la, esta fica cinco anos sem falar com ele

6 anos Sentia-se entediado em Catanduva, gostava de vir para São Paulo, onde sua avó comparecia de 2 em 2 meses para exames, pois usava marca-passo. Em SP ficava na casa de seu tio J., Pegava ônibus e ficava horas conhecendo novos lugares.

Pm. declara que podia contar sempre com sua avó.

8 anos

9 anos

Pm acordava cedo e ia trabalhar na feira, em seguida, voltava para casa e freqüentava a escola, no período da tarde. 


\section{Circunstâncias}

Pm conta que havia muita briga na casa de sua tia e a família ficava sem se falar.

Na região da Rebouças, estabeleceu vínculos com M (educadora de rua) e $\mathrm{MH}$ (voluntária em projetos sociais)
I dade/ ano

\section{Sujeito}

11 anos Não gostava de estudar.

Um dia, resolve que não ia mais voltar para casa, isso ocorre repentinamente. Vive pelas ruas de Pinheiros, passa fome e frio, no início, e, aos poucos, vai se adaptando.

Faz amizade com 2 garotos; surfa nos trens e ensina seus amigos a ler.

Sentia-se intimidado pelos policiais, mas mas nunca foi preso.

Refletiu sobre seu modo de vida, considerando a perda de seus amigos, que foram presos ou viciaram-se em drogas.

Voltou a estudar à noite, mas continuou morando nas ruas.

Conta que pouco se envolveu com a droga.

Passou por alguns abrigos, mas não se adaptou.

17 anos Passa a morar na AMC desde a sua inauguração

19 anos Concluiu o segundo grau e pensa em fazer Faculdade.

Trabalha e tem sua mobília, pois já ultrapassou o limite de idade (18 anos) para permanecer na AMC.

Forçado pela pressão de ter de deixar o abrigo, abandona o emprego e seus pertences e volta a morar nas ruas. 


\section{Resumo das entrevistas}

Pm. nasceu em Osasco (município de São Paulo), em 1984. Seu pai foi preso, pouco antes de ele nascer. Ele morava com sua mãe $C$ e suas duas irmãs, Cf.( 8 anos mais velha), Pf. ( 4 anos mais velha). Sua mãe C., que deu à luz Pm., aos 22 anos de idade. Sua primeira filha nasceu, quando ela tinha 14 anos de idade.

Conta que se dava bem com sua irmã mais velha, que tomava conta dos irmãos, quando a mãe saía para trabalhar, mas que a irmã do meio "era muito briguenta". Sua mãe abandonou os filhos, para ir morar com o namorado, quando nosso sujeito tinha dois anos de idade. Ele conta que lembra apenas que um dia não viu mais sua mãe e que ficaram, eles três, dentro da casa. Sua irmã mais velha, na época, com dez anos de idade, tomou conta dos irmãos. Passaram-se "dois ou três meses", até que sua tia C2. veio buscá-los e os levou para morar em sua casa. Esta sua tia bebia, e na sua casa havia muitas brigas, as pessoas ficavam longo tempo sem conversarem.

Sobre sua irmã mais velha, Pm. conta que ela era "muito sentimental, muito chorona" e que ele acredita que, por ser mais velha, e perceber mais as coisas, deve ter presenciado alguns fatos que a abalaram, pois seu pai era envolvido com o crime. Diz que, uma vez, brincando, quando tinha cinco anos de idade, falou que ia matá-la e sua irmã ficou quase cinco anos sem falar com ele. Diz que faz dois anos que não a vê, e que sua família é distante, afetivamente.

Depois do abandono de sua mãe, Pm. ficou morando alguns meses na casa de sua tia C2 e, em seguida, no ano de 1987, vai morar em Osasco com sua avó, mãe de seu pai, onde ficou por dois anos. Nesta época, o seu tio J., irmão de seu pai, representou um papel muito importante para Pm.: "como se fosse uma figura paterna". Ele conta que a mulher de seu tio não gostava dele, pois J. tratava-o da mesma forma, como a seu filho, e que ele, de fato, se sentia como irmão de seu primo.

Em 1989, mudam-se para Catanduva: ele, sua avó, sua tia S., o marido dela A., e as 3 primas A. f. 5 anos, M. f. 10 anos e D. f. 2 anos. Seus tios ficam apenas por um ano e voltam para São Paulo, por não conseguirem trabalho na região, mas deixam a filha mais velha, M. f. 10 anos, morando com Pm. e sua avó.

Pm. conta que sua avó defendia-o de tudo, ele relata que gostava bastante dela: - “Ah..., a minha avó era uma pessoa super-legal, sabe, ela me protegia, 
quando eu fazia alguma arte, ela não é legal por isso, só por isso, mas ela era legal, quando eu fazia alguma arte ela tava do meu lado, ela sempre tava do meu lado, sabe, então era uma pessoa que eu contava com ela, sabe, acho que foi a única pessoa do mundo que eu pude contar com ela, sabe, por mais que tenha sido por um curto período né, mas ela sempre tava ali".

As relações com sua prima, que morou com eles até 1992, foram boas. Pm. conta que não gostava de morar em Catanduva, a escola era longe e ele tinha que andar muito para chegar até ela; que não tinha muito que fazer e se sentia entediado. Ao lado de sua casa havia um canavial e um rio. Seu prazer era vir para São Paulo, de tempos em tempos, acompanhar sua avó, que vinha para fazer exames médicos, pois usava marca-passo. Em São Paulo, ficavam hospedados na casa de seu tio J.. Pm. conta que sempre foi muito curioso e gostava de conhecer os lugares. Diz que pegava o ônibus e andava horas, apreciando lugares novos. Afirma que seu tio dizia que ele podia sair e andar por onde quisesse, mas que deveria obedecer a duas regras: estar em casa na hora do almoço e voltar às 18,00 horas.

Em 1987, aos 30 anos, falece seu pai, vitima de doença cardíaca. Esse problema no coração é hereditário, por parte da família paterna, sendo que sua avó, seu pai e o próprio Pm. sofreram com ele. Pm. foi tratado desde pequeno e se diz curado.

Pm. foi visitar seu pai na prisão, por duas vezes, isto ocorre antes de ele completar três anos de idade. A primeira vez, foi no dia dos pais, quando sua tia C. o levou e, em outra ocasião, quando ele foi com sua avó. Pm. guarda forte recordação da sua primeira visita, quando, ao chegar próximo de seu pai, este o pegou nos braços, levantou-o e disse aos amigos: "Este aqui é o meu filho!". Pm. acredita que se seu pai não tivesse morrido, a família teria se mantido unida.

Sobre a fama negativa do pai, diz que não sabe em quem acreditar, pois cada lado defende seus interesses. A família da sua mãe falava que seu pai batia nela, e a família do seu pai nunca falou mal do seu comportamento. O que parece consensual é que ele sempre proveu financeiramente a família. Pm. afirma que, em seu íntimo, não acredita na versão da família de sua mãe, mas, em outro momento, conta que seu pai era "sanguinário".

Quanto ao temperamento da mãe, ele lembra que ela era meio nervosa, apenas isso, não tem recordações de sua mãe, lembra dela apenas por fotos. Sobre ela, 
e a época em que foi abandonado, ele fala: “Não, eu não lembro, eu só lembro de que pareceu assim, que a gente estava trancado, sabe, a gente não tava trancado, mas a gente se sentia, sabe, quando a gente se sente assim sozinho? Cadê minha mãe e tal? E eu não conhecia ninguém lá aonde a gente morava, minha irmã conhecia. É eu só lembro assim, de eu estar num lugar um pouco escuro assim e tipo sozinho, sabe quando você tá sozinho e você procura as pessoas, tipo assim não acha, bom acho que, de certa forma, deve ser isso que deve ter bloqueado assim parte das lembranças que eu tinha da minha mãe, tanto que eu, tipo, carreguei uma mágoa dela assim, sabe antigamente eu não gostava dela não, aí eu conhecia uma pessoa que ela, sabe, falou assim: - Pô, pensa bem, a tua mãe tinha 24 anos, como será que era pra ela, isso, aquilo. Mas, mesmo assim, até hoje eu queria, sim, encontrar ela, só pra gente conversar sabe. (....) Bom eu só queria perguntar pra ela porque ela foi embora, nada mais, não queria nem viver com ela, nem passar a gostar dela (risos) sabe". Pm. diz que ela mora no Taboão e, como ela sabia onde encontrar os filhos, teria procurado, se quisesse vê-los.

Em 1993, sua avó falece. Pm. diz que acordou cedo e foi comer algo e sua avó continuava dormindo, um senhor vizinho foi chamar por ela e constatou a sua morte.

Pm. diz que muita gente da região veio ao velório e ele conheceu vários parentes, sobre os quais, nem sabia da existência. Ele fala que nunca vai a enterros, que se você quer fazer algo por alguém ou demonstrar seus sentimentos, deve fazê-lo, em vida.

Com a morte da avó, Pm. vem morar em São Paulo na casa de seu tio J., com quem fica por 4 meses. Em seguida, volta a morar com sua tia C., quando reencontra suas irmãs. Sobre elas, diz que a mais velha era muito sentimental e a irmã do meio era briguenta, não o respeitava como o "homem da família", coisa que sua irmã mais velha e as primas faziam. Pm. conta que sua irmã do meio (Pf.) saiu de casa, quatro ou cinco meses depois que ele chegou. Inicialmente, ela foi morar com a família, por parte de pai, depois, foi para a rua e Pm. nunca mais soube dela.

Ele conta que, na casa de sua tia C2, havia muita briga e as pessoas ficavam sem se falar; que sua tia bebia e chegava a bater no marido. O clima foi melhorando, aos poucos, à medida que um primo casou e saiu de casa, eles foram crescendo e, no final, ficaram Pm., sua tia e uma prima. Conta que sua 
tia preocupava-se com as suas companhias e que ela cobrava muito, queria que ele estudasse e trabalhasse, aprendesse a cozinhar, lavar e passar; que ele fosse para o lado honesto da vida. Com seu tio, a relação era distante. Pm. conta que trabalhava na feira, acordava cedo e, depois do trabalho, voltava correndo para ir estudar à tarde, diz que era puxado e que não gostava muito de ir para a escola.

Sua saída de casa foi repentina: certo dia, resolveu que ia dormir na rua e que voltaria alguns dias depois, queria ficar sozinho, isto foi em 1995, quando ele tinha 11 anos de idade. Foi para uma região de Pinheiros, perto do Largo da Batata, que ele conhecia por causa do seu trabalho em feiras livres e passou a tomar conta de carros e, assim, foi ficando e não voltou mais para a casa de sua família. Instalou-se em uma casa abandonada, onde ficou por seis meses. Passou a ajudar a vizinhança, carregando sacolas e fazendo pequenas gentilezas. Acabou ganhando a simpatia e a aceitação da vizinhança. Afirma que aprendeu muito com um morador de rua, que o ensinou como sobreviver nas ruas. Pm. conta que passava os dias pensando que, na rua, não tinha as cobranças que tinha em casa. Por outro lado, foi difícil sua adaptação no primeiro ano, chegou a passar frio e a ficar dias sem comer, mas, mesmo assim, não desejava voltar para casa. Depois, foi se adaptando e conhecendo outras pessoas na mesma condição, fez amizade com dois garotos T.. e M.. Passaram a andar juntos, surfando em trens e pegando rabeira de caminhões.

Diz que a rua o fez aprender a lutar para sobreviver, a se impor diante das situações e "exercer autoridade nas suas palavras", que ela the ensinou muitas coisas. Que havia, na época, regras entre os meninos de rua de Pinheiros. Eles não podiam roubar nas imediações e deviam relacionar-se bem com a vizinhança.

Pm. diz que sempre gostou de ler e conversar, e que procurava intermediar as brigas, buscando o diálogo entre as partes. Diz que incentivou seus dois amigos a aprenderem a ler e a freqüentarem a "gibiteca" e que isto é motivo de orgulho para ele.

Pm. conta da relação estressante e perigosa com os policiais, enquanto vivia nas ruas; mas nunca foi preso. Quando começou a freqüentar a av. Rebouças, voltou a interessar-se pelos estudos. Freqüentava a escola à noite, mas continuou morando nas ruas. Conta que passou pelo Exército da Salvação e pelo Projeto Vida, vindo para a AMC, em março de 2001, logo na abertura da casa. Conta que 
ver seus conhecidos serem presos e outros se envolvendo, a fundo, com as drogas, levou-o a reconsiderar seu modo de vida; que, nos abrigos, "o correto seria o adolescente ser tratado como uma pessoa que está enfrentando dificuldades, está em desenvolvimento e tudo aquilo que você puder ensinar para aquela pessoa é bom (....) mas te vêem como marginal ou coitado, você não é tratado como uma pessoa que pode fazer alguma coisa, que tem potencial". Diz que a diferença da AMC é o interesse que a educadora M. e a voluntária M.H. dispensaram a ele, afirma sentir um "laço afetivo" com elas. Diz que as duas desempenharam um papel que, até então, ele não conhecia, elas confiaram e depositaram esperança nele, mesmo diante de algumas recaídas. Conta que a voluntária M.H., que é professora das Faculdades Santa Marcelina, está vendo a possibilidade de arranjar-Ihe uma bolsa de estudos para ele cursar Relações Internacionais ou Ciências Sociais.

Pm. conta que seu envolvimento com a droga foi pequeno, ele procurava evitála, embora a tenha usado. Diz que nunca viu a sua situação como definitiva, sabia que, mais cedo ou mais tarde, ia deixar as ruas e mudar a sua vida.

Pm. não namora, embora já tenha tido envolvimentos passageiros. Afirma que pretende construir sua vida, estabilizar-se primeiro, para, depois, pensar em constituir família.

\section{Observações}

Pm. é um jovem alto, de porte avantajado e que se apresentou bem cuidado e com aparência saudável. Relatou sobre um problema no coração, de origem hereditária, tratado com sucesso, já em idade precoce.

É um dos primeiros adolescentes a ingressar na AMC. Tem-se a impressão de que ele sente aquela casa como o seu lar. Está terminando o terceiro ano do segundo grau, e trabalha em uma produtora de som, como office boy, ficando pouco tempo na AMC., durante a semana e, mesmo, nos finais de semana. Notamos que Pm. é uma pessoa diferenciada, com um bom nível intelectual e cultural. Com quase 19 anos, ele não pode mais permanecer na AMC, que abriga os jovens até a idade limite de 18 anos. Pm. já tem seus móveis, para mobiliar um local para ele mas, embora concordando com a norma que o obriga a procurar outro lugar, parece resistir a essa mudança, encontrando dificuldades para sair e arrumar um local ou, se encontra algum, cria obstáculos para sua transferência. 
É um jovem educado, que sabe se expressar. Mantém uma atitude reservada dentro da casa, relacionando-se pouco com os outros adolescentes. Tem um vínculo especial com M., uma educadora, que ele conhece desde os 13 anos, e com M.H., uma voluntária que ele conheceu na mesma ocasião - duas pessoas atualmente vinculadas à AMC. A impressão que temos é que aquelas pessoas são a "família" de Pm. e que ele não deseja separar-se delas, indo morar sozinho.

No segundo semestre de 2004, em contato com a diretoria, soubemos que Pm. deixou a AMC. e foi morar na casa de uma pessoa, cuja identidade não nos foi revelada, ficou pouco tempo nesta casa e, em seguida, voltou a morar nas ruas, largou seu emprego, seus planos e a mobília que tinha ganhado para montar sua casa.

\section{Resultado dos testes}

\section{HTP}

As análises dos desenhos sugerem:

> Tensão interna

$>$ Humor deprimido.

$>$ Carência afetiva.

$>$ Sentimentos de vazio interior.

> Supervalorização do intelecto, ambição intelectual.

> Fraca identificação com a figura masculina.

> Repressão de seus interesses sexuais genitais.

> Idealização das relações, de um modo geral.

$>$ Bons recursos do ego.

\section{TAT}

A análise das estórias indica:

$>$ Bons recursos de ego. 
$>$ Busca de identidade.

$>$ Dificuldades no relacionamento interpessoal.

$>$ Persistente receio de abandono ou luto.

> Confiança na superação de dificuldades na adaptação à vida.

\section{I nterpretação dos dados}

Destacamos que a mãe de nosso sujeito dá à luz, já aos 14 anos. Cabe aqui questionar se, do ponto de vista emocional, meninas nessa idade estão suficientemente amadurecidas para exercer tal função.

É possível que para C., as circunstâncias tenham se tornado muito pesadas com a prisão do marido e sua conseqüente responsabilização pelo sustento da família. Após dois anos, abandona os filhos pequenos e vai morar com outro homem.

Diante disto e do que vimos no resumo da vida de Pm., podemos considerar que o período mais precoce do desenvolvimento de nosso sujeito (até seu terceiro ano de vida) foi, aparentemente, um ambiente potencialmente desfavorável para o desenvolvimento emocional.

Passada essa etapa (de abandono materno, de mudança para a casa da tia e de morte paterna) Pm. muda-se para Catanduva, uma cidade da zona rural de São Paulo, sob os cuidados da avó paterna, onde, relata, ter recebido apoio e afeto. Nosso sujeito parece ter encontrado em sua avó uma pessoa suficientemente continente, dando condições para que Pm. experimenta-se uma sensação de segurança e confiança. Esse fato ocorre a partir dos três anos de idade, fase muito importante na estruturação da personalidade e do caráter do ser humano. Aos nove anos de idade, com a morte da avó, Pm. volta para casa dos tios, onde, do ponto de vista das relações interpessoais, Pm. refere uma lembrança de muita exigência, frieza e rancor. Fato é que neste momento sai de casa e vai para as ruas, o que nos dá margem a inferir sobre a possibilidade de uma reatualização de sua experiência de abandono/rejeição em época precoce da infância, mobilizando suas inseguranças pessoais.

Nosso sujeito, com oito anos de idade, já gostava de passear sozinho por São Paulo, pegando ônibus com o simples propósito de conhecer os lugares do trajeto. Não consideramos esse interesse como um fator determinante para a 
fuga de casa, mas importa considerá-lo em um papel coadjuvante. Pm. conta que certo dia resolveu sair de casa e passar um ou dois dias na rua para, depois, voltar para casa, ocorre que gostou da experiência e nunca mais voltou. Lembra que ficava comparando o ambiente rígido de sua casa e a sensação de liberdade que as ruas lhe proporcionavam.

Nas ruas, Pm. logo arranjou uma maneira de sobreviver, fazendo amizade com a vizinhança, ajudando-os com sacolas e varrendo calçadas, assim como tomando conta de carros.

Com o tempo, fez dois amigos, com os quais passou a compartilhar o dia-a-dia. Nosso sujeito demonstra um interesse em estabelecer normas e valores de comportamento para si e entre os amigos: pela não adesão ao uso de drogas; pelo interesse em levar seus amigos à 'gibiteca' e incentivá-los a interessar-se pela leitura, e; pelas ambições intelectuais que demonstra.

Por outro lado, à luz de nossas observações e de seu relato, percebemos que hoje apresenta dificuldades para vincular-se, embora demonstre profunda necessidade de contato e acolhimento afetivo. Há algo na figura paterna que, como dissemos anteriormente, o marcou profundamente e que parece ter se tornado uma referencia de amor, orgulho e aceitação dirigidos à si, pelo pai. Esta lembrança, ou esta referência parece influenciar sua auto-estima e contribuir para a estruturação de uma maior segurança emocional.

O acolhimento da avó parece ter fornecido uma boa dose de segurança e sentimentos de aceitação, o que incrementou a experiência de um objeto interno bom e auxiliou o sujeito a preservar aspectos positivos da personalidade, como o cuidado com sua integridade física, sua auto-estima e desejos de desenvolvimento e reconhecimento. Tem desejo de constituir família e reconciliar-se com a sua, ajudar seus amigos e desenvolver-se intelectualmente, para poder ser reconhecido e desenvolver melhor sua autoestima (que pode lhe dar segurança e amor próprio). Possui valores morais e éticos, com certa flexibilização das normas internas.

Há, porém, uma instabilidade na manutenção da sua linha de conduta, revelando uma estruturação de ego fragilizada, possivelmente devido a intensos impulsos destrutivos, mantidos sob forte controle, com o auxílio da intelectualização.

Em tese, este sujeito que se desenvolveu razoavelmente bem, parece necessitar de um ambiente, ou uma pessoa, que Ihe fornecesse a segurança e a continência afetiva necessária para auxiliá-lo na elaboração de seus impulsos agressivos, 
para que ele pudesse não sucumbir facilmente às frustrações e dificuldades naturais da vida, e pudesse utilizar melhor sua energia para a maturação da personalidade.

Para finalizar, desejamos destacar que mantivemos contato com os profissionais da AMC., em meados do segundo semestre de 2004, que nos contaram que P., não podendo mais continuar morando no abrigo e, embora tendo mobília, roupas, emprego e apoio de pessoas da casa, abandonou seu projeto e voltou para as ruas, sendo visto por alguns funcionários, sujo, mal vestido, e afirmando que havia voltado para as ruas.

\section{CONSI DERACÕES FINAIS}

As famílias de nossos sujeitos passaram por mais de uma circunstância, potencialmente adversa, para a estabilidade emocional dos indivíduos e das suas relações interpessoais, fatos que ocorreram em épocas precoces da maturação dos jovens entrevistados. Em uma família, a interação afetiva é bastante operante (mesmo naquelas em que observamos uma aparente frieza e distanciamento), tendo importantes reflexos sobre o mundo interno de seus membros e, principalmente, no das crianças. A ocorrência de circunstâncias desestabilizadoras, na dinâmica familiar, pode repercutir sobre a dinâmica de um dos indivíduos, em particular, assim como a desestabilização emocional de um indivíduo pode se refletir sobre a família, como um todo. Circunstâncias adversas, dentro de uma família, pode estabelecer em um ou mais dos seus membros, desequilíbrios emocionais agudos e, dependendo da intensidade do estímulo, do tempo de duração da adversidade e as características pessoais dos indivíduos, esses desequilíbrios podem vir a se tornar crônicos. Em geral, as crianças e as personalidades mais frágeis são as que sofrem os maiores agravos. Para uma criança pequena, que possui um aparelho psíquico ainda em desenvolvimento, circunstâncias de extrema frustração podem afetar mais marcadamente a constituição de sua personalidade. 
Nos depoimentos e análises dos testes, constatamos que todos os nossos sujeitos apresentam grande sofrimento interno, por viverem afastados de suas famílias; nota-se, também, o sentimento de frustração, por terem de se defrontar, freqüentemente, com o conflito entre atender suas exigências de prazer fácil e seu desejo de amadurecer, o que parece consumir muito de sua energia e desviá-los, constantemente, de seus objetivos; parecem não acreditar que possam desenvolver recursos próprios para realizar seus sonhos. Esses jovens tiveram circunstâncias de vida difíceis, com vivências de negligência, rejeição (declaradas ou subliminares), violência, perdas, rupturas e faltas, com intensidades variadas; não obstante, consideramos que todos eles possuem aspectos saudáveis em suas personalidades, expressos na busca de uma integração, no interesse em desenvolver-se e a inserir-se em nossa sociedade, assim como desejos de reparar os danos ocorridos. Em outras palavras, ponderamos que nossos sujeitos encontraram, já na sua primeira infância, um Potencial Circunstancial (ROSENBURG 2002) desfavorável para seu desenvolvimento emocional adequado, entretanto, puderam, também, vivenciar circunstâncias favoráveis, que possibilitaram que o impulso para a vida, para a integração e desenvolvimento também se estabelecesse em suas personalidades.

A grande maioria de nossos entrevistados funciona, predominantemente, sob o regime do processo primário do pensamento, que busca alcançar o prazer, de forma imediata, e evitar o desprazer, sem levar em consideração os dados de realidade. Isto indica uma inibição na passagem para etapas posteriores do desenvolvimento psico-sexual, que possibilitaria a utilização mais intensa e freqüente do processo secundário do pensamento, que considera a realidade externa e compreende suas leis de funcionamento, podendo levá-los a uma atitude mais ativa na busca de sua auto-construção. Se, por um lado, é possível vislumbrar fortes aspectos deste processo primário de pensamento nas constantes 'recaídas', em que os jovens saem do abrigo e passam dias na rua "curtindo", utilizando drogas e, algumas vezes, praticando delitos, e interrompendo seus projetos; por outro lado, podemos vislumbrar elementos pertencentes ao processo secundário, no movimento de retomada de seus planos, que implicam rotina, disciplina, estudos e o adiamento de satisfações.

Houve momentos, em suas trajetórias, em que eles foram bem longe, quase atravessando uma fronteira para um território difícil de voltar; alguns de nossos sujeitos reconsideraram seu estilo de vida, à medida que iam sofrendo e sendo 
testemunhas dos danos causados por essa forma de viver: o uso de entorpecentes, cada vez mais freqüente, e em maior dosagem ; eles próprios e seus amigos sendo presos, envolvidos em brigas ou mortos; perseguidos pela polícia, além de sofrerem com o peso da discriminação social. Entretanto, alguns de nossos entrevistados declararam que nas ruas, também, encontram amizade, solidariedade, proteção, afeto e auto-organização, declarações que coincidem com os achados de MEJíA-SOTO (1998).

Baseados em nossos pressupostos teóricos, podemos concluir que, mesmo enfrentando adversidades na fase do "Cordão Umbilical Afetivo", esses jovens receberam uma boa quantidade de investimento afetivo, vivido como experiências positivas, ainda em idade precoce, o que pôde mantê-los com áreas razoavelmente preservadas em sua personalidade, em linguagem psicanalítica, puderam introjetar objetos bons.

O que consideramos relevante para o processo de desenvolvimento do ser humano, não é a família em si, no sentido de uma instituição, mas sim, de pessoas, parentes ou não, com capacidade de investir sua energia, seu interesse, de forma madura e saudável, na promoção do desenvolvimento de alguém, que dele necessita, para superar seus primeiros anos de vida e poder amadurecer, de forma saudável.

Contextualizando a questão, CALLIGARIS (2004) percorre as mudanças de pensamento dentro do campo da psicologia e relembra que, há 4 décadas atrás, a família era vista como o "berço da loucura", um refinado instrumento de domínio, que subjugava os jovens às normas vigentes. Naquela época, também, tomou força um movimento, que procurava desmontar os esquemas de confinamento dos pacientes psiquiátricos e devolvê-los à família e à sociedade. Estava criado o problema, devolver o doente mental à fábrica de loucura (a família). Atualmente, o que encontramos é uma bibliografia que valoriza a família, que, devidamente instruída, torne-se a terapeuta de seus membros doentes.

Desejamos destacar aqui MELANIE KLEIN (1982:258) que afirma:

Devemos ter presente, entretanto, que por muito importante que sejam essas primeiras influências, o impacto do meio é da máxima importância em todos os estágios do desenvolvimento infantil. Mesmo o bom efeito da criação nos primeiros tempos pode ser, em certa medida, anulado através de ulteriores experiências 
prejudiciais e maléficas, assim como, as dificuldades surgidas no começo da vida podem ser mitigadas através de subseqüentes experiências benéficas. Ao mesmo tempo, convém recordar que algumas crianças parecem recordar condições externas desfavoráveis sem grande dano para seu caráter e estabilidade mental, ao passo que em outras, apesar de um ambiente favorável, manifestam-se e persistem sérias dificuldades.

Consideramos que nossos sujeitos podem ser classificados como meninos "na" rua que, diferentemente dos meninos "de" rua, mantinham contato com suas famílias; alguns viviam circulando entre abrigos e as ruas e outros estavam abrigados na mesma instituição, havia mais de dois anos, indicando uma capacidade de manter vínculos mais estáveis. Cabe a ressalva que, dentre os nossos sujeitos, não encontramos indícios de vínculos de extrema dependência, simbióticos, assim como vale lembrar que crianças que não param em lugar nenhum e desligaram-se completamente da família parecem carecer de "pontos fixos" (ALVAREZ 1999), que funcionam como elementos de proteção. Entre nossos jovens, todos manifestaram o desejo de construir uma vida com uma família e ter uma profissão, além de restabelecer os laços com suas famílias de origem.

Em conformidade com o trabalho de ANTONI \& KOLLER (2000:347), também encontramos em nosso grupo uma tendência à idealização da família e expectativas sobre a formação de suas próprias famílias no futuro. "Esta atitude pode ser vista como proteção frente às situações de risco às quais estão expostas, em função da expectativa de mudança qualitativa nas relações familiares futuras".

Nossos sujeitos encontraram pessoas, em fases mais tardias de sua infância, que se tornaram elementos de referência positiva em suas vidas, assim como puderam experimentar o sentimento de que foram importantes para alguém, fato que parece tê-los auxiliado, emocionalmente, na constituição de sua segurança interna e auto-estima. Constatamos essa afirmação nos depoimentos de Pm., que se refere à relação com sua avó e com duas pessoas da AMC., as quais Ihe proporcionaram segurança afetiva. Pf. encontrou em D., a pessoa que a criou, uma relação que Ihe forneceu confiança e auto-estima. C., apesar de todas as dificuldades vividas, declara seu afeto por sua mãe, e o desejo de ajudá-la a melhorar suas condições de vida. 
Essas referências positivas podem estar desveladas no fato de os sujeitos Pm. e F. praticamente terem terminado o segundo grau, em idade compatível, Pf. com 16 anos ter completado o primeiro grau; no sentimento de $\mathbf{C}$., que afirma: "fazer - curso de culinária foi a coisa mais importante de minha vida"; na disponibilidade de E., que aprendeu o ofício de padeiro, tornando-se monitor e tendo planos de continuar investindo em seus estudos.

Historicamente, a compreensão sobre a personalidade e caráter do homem foi se tornando mais rica e complexa. Passou de concepções que consideravam o modo de ser do indivíduo, como parte de sua natureza, algo imutável, e concebiam os transtornos de personalidade e caráter como degenerações do organismo, para outras mais complexas, que contemplaram um aprofundamento em determinados aspectos da complexidade da psique, como as teorias, de inspiração no modelo estímulo-resposta, outras que concebiam o comportamento como resultante das interações bio-químicas, aquelas que consideravam a interação com a sociedade e com a família, como também as que afirmam que a realidade externa não faz nenhuma diferença, pois tudo se passa no interior da psique do indivíduo, e depende dos significados atribuídos por ele às experiências vividas, além de outras, que não nos cabe enumerar, que trouxeram suas contribuições para o entendimento do comportamento humano. Consideramos a questão do desenvolvimento emocional das crianças, sob a perspectiva de uma ordem complexa, em que nos parece mais razoável falarmos em termos de "Potencial Circunstancial", como uma configuração que favorece a ocorrência de determinados eventos.

De maneira sintética, podemos dizer que o desenvolvimento emocional da criança pode ser compreendido da seguinte forma: inicialmente, temos uma situação (fase do Cordão Umbilical Afetivo), na qual a criança se apresenta extremamente dependente dos adultos e justamente em uma etapa, em que ocorre, de maneira crítica, seu processo de formação orgânica e psicológica; os adultos importantes em sua vida constituem o seu "ambiente" e afetam diretamente o mundo interno (emocional) dessa criança, assim como são afetados por ela; este ambiente familiar/emocional está sob a influência das circunstâncias do macro-ambiente, isto é, ocorrências da existência que afetam, positiva ou negativamente a qualquer um de nós. Cada um desses indivíduos possui uma competência inata para fazer frente às adversidades, com diferentes capacidades de resistência, isto é, com maior ou menor tendência à desorganização interna e uso inadequado de mecanismos de defesa. Esta 
situação complexa, dinâmica e que perpassa ocorrências da ordem do simbólico, pode ser compreendida através do conceito de Potencial Circunstancial, que procura compreender o evento em termos de um conjunto de variáveis que detém, em si, uma força, um potencial que poderá influenciar o sentido de um evento.

É importante destacar que a adolescência é um período que re-atualiza os conflitos edípicos, que se formaram na infância, e que se mantiveram "adormecidos" durante a fase denominada Latência (aproximadamente dos seis aos dez anos). Considera-se que a re-atualização dos conflitos no adolescente faz parte de um processo de desenvolvimento normal e crítico, de saída da infância e entrada na vida adulta, necessária para a individuação do jovem. Se, durante a formação do jovem, houve falhas ou dificuldades importantes em certas etapas de seu desenvolvimento, a adolescência é o período em que esses conflitos irão eclodir de forma mais violenta e conflitiva, somando-se às dificuldades típicas do desenvolvimento emocional que enfrenta um adolescente.

Consideramos importante o papel que desempenham algumas instituições que oferecem medidas para auxiliar esses jovens, alguns deles, aproveitando-as intermitentemente, indo e vindo, de acordo com sua dinâmica pessoal; outros, aproveitando o que Ihes foi oferecido para desenvolver sua autonomia, através da educação, profissionalização e re-inserção familiar e social. Destacamos, porém, alguns fatores que devem ser repensados e aperfeiçoados, como a inspiração assistencialista de muitas dessas instituições, que perdem a oportunidade de prepararem esses jovens para amadurecerem e enfrentarem a vida com seus próprios recursos, mantendo-os como vítimas de uma sociedade, que merecem pena e cuidados. Ainda há aquelas inspiradas em modelos disciplinadores, que acreditam que determinados métodos podem "dobrar" a impertinência dos mais atrevidos.

Uma outra importante questão, do ponto de vista do Direito da Criança e do Adolescente, sobre o qual há muito que se refletir e questionar, em especial, sobre a concepção de distúrbios de conduta, ações corretivas e o conceito de maturidade. Somos levados à reflexão sobre suas origens, seu desenvolvimento e a terapêutica aplicada a esses distúrbios. Cabe, também, refletirmos sobre as ideologias que sustentam os projetos de institucionalização de crianças e de jovens, algumas vezes, para "manter as ruas limpas" e oferecendo ações de recuperação míopes, que buscam enquadrar os jovens em determinadas condutas, ensinando-Ihes princípios de higiene, dando-lhes educação formal, 
alimentação, vestimentas e assistência à saúde, mas deixando de encarar o triste e dramático fato de que existem faltas básicas, que dificultam a estruturação emocional desses jovens, sua maturidade, sua confiança e autoestima. Nossa experiência nos deixou um exemplo para reflexão sobre esse tema, o caso de $\mathbf{P m}$. que, por força de já ter ultrapassado os 18 anos e ter de deixar a Instituição, mesmo tendo apoio, emprego e mobília, largou tudo e voltou a morar nas ruas. Nossa hipótese é de que a idade de 18 anos não é um critério de avaliação confiável, para medir maturidade emocional, e que nesse caso, Pm., tendo que sair da AMC. e de perto daquelas pessoas com quem tinha um forte vínculo afetivo, re-atualizou antigas fantasias de abandono, fragilizando-se internamente e voltando para as ruas, e, mais importante, perdendo o curso que vinha imprimindo à sua vida.

Assim, deixamos aqui um convite à reflexão sobre os modelos de recuperação, adotados pelo Estado e, mesmo, pela sociedade civil que, quando não procuram oferecer um vínculo mais próximo, acolhendo e respeitando a individualidade dos jovens, não conseguem que eles permaneçam na instituição. Além de levantar a questão sobre os esforços empreendidos para um trabalho que busque a reinserção familiar, experiências que vêm sendo realizadas, e que tem demonstrado bons resultados.

Concluímos este trabalho esperançosos de que sejam ampliados os esforços das instituições de ensino na formação de profissionais, fornecendo condições para que eles desenvolvam uma visão mais abrangente, que contemple as esferas do biológico, do emocional e das condições sociais, como fatores potenciais que interferem no desenvolvimento humano e, conseqüentemente, na saúde e na doença. E desejamos, ainda, mais fortemente, que se desenvolva um atendimento, que contemple a Saúde Mental, sob a perspectiva de prevenção de distúrbios emocionais e de doenças de fundo emocional, adotada e exposta por este trabalho, ressaltando a importância dos conceitos de “Cordão Umbilical Afetivo" e de "Potencial Circunstancial" para a Saúde Pública.

Se nossas recomendações surgem como uma condição ideal, lembramos que é tendo o ideal, como horizonte, que podemos trabalhar para aperfeiçoar as condições de vida do ser humano. 


\section{REFERÊNCI AS}

Alvarez AMS. A resiliência e o morar na rua: estudo com moradores de rua - crianças e adultos - na cidade de São Paulo. São Paulo; 1999 [Dissertação de mestrado - Universidade de São Paulo - Faculdade de Saúde Pública].

Antoni C de, Koller SH. A visão de família entre as adolescentes que sofreram violência intrafamiliar. Est Psicol. 2000; 5(2): 347-81.

Badinter E. Um amor conquistado. $2^{\mathrm{a}}$ ed. Rio de Janeiro: Nova Fronteira; 1980.

Balint M. A falha básica; aspectos terapêuticos da regressão. Porto Alegre.: Artes Médicas; 1993.

Birman J. Leituras sobre a cientificidade da psicanálise. Rio de Janeiro: Ed. da UERJ/IMS; 1992; (14). (Série Estudos em Saúde Coletiva).

Bowlby J. Formação e rompimento dos laços afetivos. São Paulo: Martins Fontes; 1982.

Brenner C. Noções básicas de psicanálise. Rio de Janeiro: Imago/São Paulo: EDUSP; 1975.

Bruscato WL. Relações objetais na esquizofrenia: um estudo comparativo. São Paulo; 2001. [Tese de Doutorado - Universidade Federal de São Paulo Escola Paulista de Medicina].

Calligaris C. Afeto e família. Folha de São Paulo, São Paulo, 2004 dez 30 [online] Disponível em: URL

http://www1.folha.uol.com. br/fsp/ilustrad/fq3012200414.htm

[UFRGS] Universidade Federal do Rio Grande do Sul. Instituto de Psicologia CEP-Rua (Centro de Estudos Psicológicos sobre Meninos e Meninas de Rua) [on-line] Disponível em <URL: http://www.psicologia.ufrgs.br/cep\%5Frua/. [2004 janeiro 2].

Costa J F. Ordem Médica e Norma Familiar. Rio de Janeiro: Graal; 1979.

D’Andréa FF. Desenvolvimento da personalidade. São Paulo: EDUSP; 1972. 
Dolto F. Psicanálise e pediatria. 3ạ ed. Rio de Janeiro: Zahar; 1980.

Elias N. A Sociedade dos indivíduos. Rio de Janeiro: Zahar; 1994.

Freud S. Obras completas. Rio de Janeiro: Imago; 1972; Três Ensaios sobre a Sexualidade; v. 7, p 123-36.

Freud S. Obras completas. Rio de Janeiro: Imago; 1974; Totem e Tabu; v. 13, p 20-198.

Freud S. Obras completas. Rio de Janeiro: Imago; 1974; Sobre o narcisismo: uma introdução; v. 14, p 85-121.

Freud S. Obras completas. Rio de Janeiro: Imago; 1974; Os instintos e suas vicissitudes; v. 14, p 129-63.

Freud S. Obras completas. Rio de Janeiro: Imago; 1976; Além do princípio do prazer, v. 18, p 13-87.

Freud S. Obras completas. Rio de Janeiro: Imago; 1976; O ego e o id; v. 19, p 13-85.

Freud S. Obras completas. Rio de Janeiro: Imago; 1976; Inibições, sintomas e ansiedade, v. 20, p 95-203.

Ghirardelli Jr. P. As Concepções da Infância e as Teorias Educacionais Modernas e Contemporâneas. [artigo online]. 1992. Disponível em: <URL: http:// www.filosofia.pro.br/textos/infancia.htm.

Klein M, Heimann P, Isaacs S, Riviere J, organizadora. Os progressos da psicanálise. 3ạ ed. Rio de Janeiro: Zahar; 1982.

Klein M. Contribuições à psicanálise. 2a ed. São Paulo: Mestre Jou; 1981.

Klein M. O sentimento de solidão. Rio de Janeiro: Imago; 1971.

Krutzen EC. Histórias de infância. [artigo online]. Disponível em: <URL: http://www.unir.br/ primeira/artigo79.html. [2002 dez 19].

Kujawski G de M.Ortega y Gasset; A aventura da razão. São Paulo: Moderna; 1994.

Laplanche J., Pontalis JB. Vocabulário da psicanálise. 5a ed. Lisboa: Moraes Editores; 1970. 
Mejia-Soto G, Rea Catañeda R, Anaya Gonzalez M, Gorab Ramirez A, Sumano Avendano E. Morbilidad de "Ios niños de la calle". Adolescencia Latino americana. 1998.

Mèredieu F de. O desenho infantil. São Paulo: Cultrix; 1979.

O 1o ENCEPROM: A - ata do painel. Alter: J Estud Psicodinamicos 1972; 2(3): 221-5

Pichon-Rivière E. Teoria do vínculo. 1aㅡ ed. São Paulo: Martins Fontes; 1982. [UNIFESP] Universidade Federal de São Paulo. Departamento de Psiquiatria Projeto Quixote [on-line] Disponível em: URL:

http://www.projetoquixote.epm.br. [05 jan.2005]

Rigato DR. Descrição do perfil sócio-demográfico e avaliação de comportamentos de risco de crianças e adolescentes atendidos pelo Projeto Quixote. São Paulo; 2002. [Dissertação de mestrado - Escola Paulista de Medicina da Universidade Federal de São Paulo].

Rigotto RM. As técnicas de relatos orais e estudo das representações sociais em saúde. Cienc Saúde Coletiva. 1998; 3 (1): p.116 - 30.

Rosa MD. O discurso e o laço social dos meninos de rua.Psicol USP. 1999; 10(2): 205-17.

Rosen G. Uma história da saúde pública. São Paulo: Unesp/Hucitec/Abrasco. 1994.

Rosenburg CP. O adolescente, o tempo e o conflito. Rev. Bras. Cresc. Desenv. Hum. 2004; v.14 n 3 set/dez. p 6.

Silva MC de VM. TAT. Aplicação e interpretação do teste de apercepção temática. São Paulo: EPU; 1989.

Soifer R. Psicologia da gravidez, parto e puerpério. Porto Alegre: Artes Médicas; 1980.

Soifer R. Psiquiatria infantil operativa. 3a ed. Porto Alegre: Artes Médicas; 1992. v.1.

Spitz RA. A formação do ego: uma teoria genética e de campo. São Paulo: Martins Fontes; 1979.

Teicher MH. Feridas que não cicatrizam. Sci Am Brasil. 2002; jul: 23-28. 
Turato ER. Tratado da metodologia da pesquisa clínico-qualitativa. Rio de Janeiro: Vozes; 2003.

Vasconcellos AT de M. Stress da Vida e Destino da Mente. In: Gomes-Pedro J., editor. Strees e Violência na Criança e no Jovem. Departamento de Educação Médica e Clínica Universitária de Pediatria da Faculdade de Medicina de Lisboa - Universidade de Lisboa. Lisboa. 1999. p. 97-122.

Winnicott DW. O ambiente e os processos de maturação. Porto Alegre: Artmed; 1983.

Winnicott DW. Privação e delinqüência. 3ạ ed. São Paulo: Martins Fontes; 2002.

Winnicott DW. A criança e o seu mundo. Rio de Janeiro: Zahar; 1966.

Zimermann D. Um novo olhar sobre a psicanálise. Viver Mente\&Cérebro. [artigo online]. 2004. Disponível em:

<URL: http://www2.uol.com.br/vivermente/ Ed. 0 [2004 set]. 


\section{ANEXO 1}

\section{Sujeito C. (feminino)}

Primeira entrevista:

R: C. eu queria começar saber um pouquinho da tua família. Você esta com quantos anos?

Cf: 15.

R: Você tem quantos irmãos?

Cf: 12 .

\section{R: 12! todos vivos?}

Cf: Sim.

R: Todos moram com você?

Cf: Não, tem um que mora no outro abrigo da casa de cima, tens uns pequenos que ta com minha mãe, o outro já é casado e ta com a mulher dele, a outra mora na casa da sogra dela, e a minha irmã mora com meu irmão, e a Jaqueline mora com o namorado dela, na casa dela...

R: Então ta..., perfeito..., mas vamos devagar (risos)... Os doze são filhos do mesmo pai?

Cf: Não.

R: Bom então vamos dividir assim, vamos dividir por pais, são todos filhos da tua mãe mas com pais diferentes. Então vamos pegar lá do mais velho pro mais novo. O nome da tua mãe como é?

Cf: M. C.

$\mathrm{R}: \mathrm{C}$ ?

Cf: C.

R: C. E você é C C. (O prenome e o sobrenome diferem apenas por uma vogal) Olha que gozado, dois nomes parecidos. E o primeiro pai?

Cf: V. G. P..

R: Você conheceu ele?

Cf: Conheci.

$\mathrm{R}: \mathrm{V}$.

Cf: G. P.

R: E onde ele ta hoje?

Cf: Ele é falecido.

R: Ah hoje ele é falecido. Faz tempo que ele faleceu?

Cf: Quando eu tinha 13 anos.

R: 13 , é recente 2 anos né. E quais são os filhos da M. com o V.? Quantos são pra eu poder escrever aqui... 
Cf: Tem a P. f. 25.

R: Fala quantos são pra eu ver o espaço aqui.

Cf: A P., D., J., S., E., E., eu, D. e a S..

R: Quanto deu?

Cf: 9.

R: Tudo do V., e depois tem mais 3 do outro pai.

Cf: O A., o L. e a A..

$\mathrm{R}$ : Ta, então deixe eu ver se consigo por os nove aqui. O mais velho de todos.

Cf: É a P.

R: P., quantos anos ela tem?

Cf: 25.

R: Depois da P?

Cf: D.

R: Tem quantos anos?

Cf: 23.

R: Depois dele.

Cf: A J.f.

R: Quantos?

Cf: 21.

R: Depois...

Cf: S. f.

R: Quantos anos?

Cf: 20.

R: Depois?

Cf: E. f.

R: Quantos?

Cf: $16 \ldots$, não 19.

R: Depois?

Cf: O E. m.

R: Quantos?

Cf: 17.

R: Depois?

Cf: Vem eu.

R: Você.

Cf: 15.

R: Depois?

Cf: D. m. 
R: Com quantos?

Cf: 13.

R: E depois?

Cf: Vem a S. f.

R: É a última.

Cf: É.

R: Com quantos?

Cf: 10.

R: E aí o V. (pai) faleceu há dois anos, quer dizer ele faleceu em 2002, por aí, você lembra?

Cf: Lembro, foi numa sexta feira.

R: Mas foi 2002 mesmo!!?

Cf: Foi.

R: Depois sua mãe casou de novo?

Cf: Não, se amigou.

R: Se amigou. E ela se amigou com quem?

Cf: U.

R: U..., e aí ela já tem 3 filhos com o U....Quem são?

Cf: O A. m.

R: A.

Cf: Tem 9.

R: Quantos?

Cf: 9 anos.

R: Ué, mas o V. (pai) faleceu há dois anos, mas ele tava separado.

Cf: Tava.

R: Ah..., depois?

Cf: A. f.

R: A., quanto?

Cf: 5 .

R: E por último?

Cf: O A...., não o L. m..

R: Com quanto?

Cf: Dois.

R: Quantos anos tem sua mãe?

Cf: 36.

R: O V. (pai) você sabia quantos anos tinha? O seu pai?

Cf: Não. 
R: Era muito mais velho?

Cf: Sim.

R: Mais ou menos quantos anos mais velho?

Cf: Não sei.

R: Pela aparência assim...

Cf: Ele parecia ter um 70 anos (risos).

R: $70 \ldots$, muito velho...

Cf: Não era muito velho não. Conhece o tio F.? Daqui da casa. Ele era um pouco mais velho que o $\mathrm{F}$.

R: E o G. m. (funcionário). Eu conheço o G.. O G. é mais velho, ou é mais novo?

Cf: Meu pai era mais novo que o G. (G. é um educador com aproximadamente 43 anos de idade).

R: Do que morreu o seu pai?

Cf: Assassinaram ele.

R: Qual a razão?

Cf: É briga.

R: Teu pai era trabalhador, ou não? Ou tava metido no crime?

Cf: Trabalhava.

R: Trabalhava.

Cf: Mas depois que ele parou de trabalhar ele começou a usar droga.

R: Foi isso que levou a morte dele!!!? Você lembra como foi isso?

Cf: Lembro.

R: Você pode contar?

Cf: Ele tava na casa da amante dele, ele tem alguns filhos com ela, aí ela pediu pra ele comprar umas coisas lá no mercado de baixo, da rua de baixo. O mercado da rua de cima tinha sido assaltado e tava fechado. Aí ele desceu né, só que ele não sabia que o cara que ele tinha treta tava morando na rua de baixo, aí ele ficou sabendo e falou assim: - Ah eu vou descer lá, eu não tenho medo dele. Aí meu pai tinha guardado a arma dele que a mulher dele pediu pra ele não descer com a arma que Deus ia cuidar dele. Aí ele desceu né, aí ele entrou no Mercado, aí ele comprou o negócio, aí daqui a pouco apareceu os cara: - Aí meu, não sei o que, vamos ali beber um negócio: - Não vou não que eu tenho que subir com uns negócio pros meus filhos. Aí ele: - Não vamos ali, não pega nada não, aquela treta já era. Aí meu pai foi no barzinho e bebeu, aí daqui a pouco tinha um alemão, um magrelo, aí ele falou assim: - É agora né? Aí os cara: -É, vamos, vamos, vamos... Os caras tiraram uma quadrada da cintura e deram 3 tiros no meu pai, aí meu pai andou...

R: Tiraram o que da cintura?

Cf: Uma 38, uma quadrada.

R: Quadrada, na gíria é quadrada?

Cf: Aí eles pegaram deram 3 tiros no meu pai e eles saíram correndo, ai meu pai não tava morto, ele tava sentado na beira da calçada, aí tem um cachorro..., um 
carrinho de cachorro quente lá e ele pediu um refrigerante pro homem, ele deu o dinheiro, só que o homem não quis vender pra ele, por causa que meu pai tava todo sangrando, aí ele tava sentado na beira da guia, o homem pegou pra baixar e pegar o celular pra ligar pros bombeiros, aí meu pai pegou um refrigerante e colocou os 50 centavos lá em cima, aí ele bebeu deu hemorragia nele e ele morreu.

\section{R: Como você soube disso tudo? Te contaram?}

Cf: Porque no dia que ele foi morto, uma semana depois eu vi o filho dele e a ex mulher dele e o cara da banquinha do cachorro quente, eu fui lá aí o cara da banquinha do cachorro quente tava me contando.

R: Teu pai trabalhava com que?

Cf: Ele trabalhava numa firma.

R: Fazendo o que?

Cf: Era pão.

R: Pão. E fazia quanto tempo que ele havia perdido o emprego?

Cf: Fazia bastante tempo.

$\mathrm{R}$ : $\mathrm{E}$ depois que ele perdeu o emprego como é que foi a vida dele?

Cf: Ele começou a usar droga, só fumava maconha e pedra. Aí os caras confiavam assim muito nele, aí os caras deu dinheiro pra ele pra ele ir buscar 4 quadrado de pedra. Assim, vem um quadrado assim, aí quando chega lá na favela eles corta em pedacinhos pra vender. Dá uns...9 mil..., dá 30 mil cada quadrado..., não...tem 4 quadrado, $3 \ldots, 12 \ldots$, deu 9,9 mil, que é 3 quadrados que ele foi buscar, aí ele pegou e sumiu. Aí toda a vez que eu ia pra escola, estudava...(ininteligível)..., sempre os caras perguntavam: - E o seu pai? Eu respondia: - Não sei não. Aí tem uma vez quando eu tava na casa do meu irmão meu pai apareceu lá de carro, ele apareceu lá de carro, terno e gravata, um Gol do vidro fume, aí apareceu lá e ele queria que eu fosse morar com ele. Eu falei que não queria ir morar com ele e aí ele pegou e foi embora, aí depois de um tempo eu fiquei sabendo que ele tinha morrido. Quando eu fiquei sabendo eu tava lá, eu tava fazendo curso lá no Quixote, aí eu tava lá, tava fazendo né, aí colocou uns negócio no forno, aí daqui a pouco, nós estava sentado lá no negócio, tomando sol, daqui a pouco quando eu passo assim eu vejo minha mãe, meus irmãos, tudo chorando e na hora eu nem entendi porque que era né, aí eu sentei assim no sofá e a tia N. veio e falou assim: - Hei C. não fica assim não.

\section{Cf: Viche tia não fica assim porque?}

tia N. Seu pai morreu, você não sabia? Nossa ai eu fiquei desesperada, eu sai pra fora, fui ficar lá fora, meus irmãos ficaram lá dentro. Depois a psicóloga chamou nós pra conversar.

\section{R: As conversas com a psicóloga foram aproveitáveis ou não?}

Cf: Foi porque ela falou também que fiar na rua não ia virar nada, aí eu falei: Eu não to na rua, eu to abrigo. Ela falou assim: - Eu sei, hoje você ta, mas amanhã você pode sair, você tem que pensar antes de sair. Minha mãe tava bebendo muito, aí nós pegamos, ela não gostava de ir no psicólogo...

\section{R: Ela ia também?}

Cf: Ia, por causa da bebida, aí nós pegamos e chamamos o psicólogo e a minha mãe ia lá e ela foi passando por um tempo ai depois desse tempo ela parou de beber, agora ela voltou de novo. 
R: Você e quem? Os filhos ou o atual marido.

Cf: Não, nós que levamos ela.

R: Nós quem?

Cf: Eu e meus irmãos, eu a P f. 25 e a E. f. 19.

R: E por que sua mãe estava bebendo? Qual o seu palpite?

Cf: Por causa do meu padrasto.

R: Ela não se dava bem com ele.

Cf: Porque ele batia muito em nós e nela, ela mandava ele embora e ele voltava, aí ela teve de mudar de casa, aí só tinha um cara que morava na rua, um conhecido dela, que sabia onde ela tava morando, ele morava lá perto, aí ele levou meu padrasto lá.

R: Você ta magoada com isso? (C. demonstrava expressão de emoção).

Cf: Uma vez minha mãe estava esquentando comida e ele jogou óleo quente na minha mãe. Queimou todo o rosto dela.

R: Tua mãe já deu parte dele na polícia?

Cf: Já só que ele ficou ameaçando ela, teve que tirar a queixa, e a última vez que ela colocou ele ficou, ele ficou uma semana, aí quando ele saiu ele queria bater na minha mãe. Aí nós tava dentro de uma casa abandonada assim conversando né, aí ele queria bater na minha mãe, ali ele bateu na minha mãe e deu um tapão na cara do meu irmão, aí tinha um tijolo assim, eu taquei na cabeça dele, abriu a cabeça dele.

R: E ele se voltou contra você?

Cf: Não, quando ele veio pra me catar meu irmão empurrou ele no chão, o D. $m$ 23, aí empurrou ele e minha ...? ... deu um pisão na cabeça dele, aí ele falou que ia matar meu irmão e saiu. Aí nós fomos pra casa.

R: Você ta fora de casa há quanto tempo?

Cf: Praticamente eu não fui criada em casa direito, que quando ela tava grávida, ela não morava em casa, ela morava tudo ali na Paulista, nós ficava muito pela rua, aí depois que nós fomos morar em casa.

R: Você nasceu na rua?

Cf: Em R. P..

R: R. P.. Quer dizer, na época em que você nasceu sua família morava em R. P.!!!!?

Cf: Morava eu, minha mãe e meu pai.

R: E o resto da turma?

Cf: Morava lá também.

R: Todo o resto. E por que vocês vieram pra São Paulo?

Cf: Porque lá era uma chácara, aí dentro da chácara tinha um quadradinho do tamanho do banheiro das meninas. Só que lá dentro tinha uma plantação de maconha..., era do meu pai. Ele trabalhava, só que ele usava assim de noite, eu não sabia o que era, nem nós conhecia isso daí. Aí..., do lado da nossa chácara morava, tinha uma fazenda que era de um delegado, morava ele e a filha dele, a mulher dele tinha morrido há uns 3 meses. Aí morava ele e a filha dele lá, aí ele 
descobriu, ele falou pro cara que deixou a fazenda junto com a minha mãe e ele falou pra nós sair de lá, aí nós fomos morar lá na favela.

R: Isso quantos anos você tinha?

Cf: Nossa nem lembro..., eu era bem pequenininha.

R: Aí vocês vieram pra São Paulo. ...E da favela como ... da favela pra Paulista como foi?

Cf: Não quando nós morava na favela nos ficava um pouco na rua também, nós fomos morar na favela mas nós vivia pra lá, Paulista, Paraíso, I birapuera...

R: Pedir dinheiro no farol?

Cf: Não, nós andava muito por aí.

R: E vivia do que?

Cf: O único que ficava assim na rua mesmo era meu irmão E. m 17.

R: Vocês andavam fazendo o que?

Cf: Nós bagunçava, zoava por aí.

R: Mas não era pra pedir esmola, era só pra sair e se divertir.

Cf: Agora o único que ficava assim na rua mesmo era o meu irmão..., o E. m 17, e depois nós começamos a ficar na rua.

R: Ele ficava fazendo o que na rua?

Cf: Ele bagunçava, ficava roubando e aí depois nós começamos a ficar na rua, por causa do meu padrasto.

R: E quando é que vocês saíram da favela? Ou saíram da Paulista. Tua mãe conheceu..., como é que foi..., ela teve uma mudança, tua mãe então conheceu o U. (padrasto), é isso? Ela se separou do teu pai em que ano?

Cf: Eu não lembro. Foi quando meu pai roubou as pedras e sumiu.

R: Quantos anos isso?

Cf: Faz bastante tempo.

R: Tua mãe se separou do teu pai por que? Eles estavam brigando, essas coisas?

Cf: Todo dia de noite os cara da favela batia nele.

R: Como?

Cf: Ele ficava xingando na porta de casa, xingando minha mãe, jogando pedra no telhado.

R: O V. (pai)?

Cf: Só que ele sabia que não quebrava. Aí meus irmãos saia pela janela, dava a volta pelo outro lado, passava pela janela do banheiro e pulava na rua.

R: Pra que?

Cf: Pra chamar os caras da favela.

R: Pra que?

Cf: Pra bate no meu pai.

R: Teus irmãos chamavam pra bater no teu pai? 
Cf: É meu pai apanhava e ia dormir. Eles não batiam pra machucar, só pra dar um chá de canseira nele. Todo dia ele tinha que apanhar, ele até acostumou com isso.

R: Mas o que ele queria? Por isso que ele fazia isso?

Cf: Quando minha mãe .... - Vai sua crente sapatona.... Ele fazia assim: - Esse aqui é o bico e esse é o Baco. (apontando para os dedos da mão). Quando ele chegava no Baco nós já tinha que ta longe. Nós subia o morro, descia o morro e ele atrás de nós, ele quase caindo no meio da rua. Uma vez minha mãe deu um soco nele que ele voou lá em cima da cama. ..., aí ele começou a xingar a minha mãe, e a mãe: - Pára, pára. E ele: - Não, não sei o que (a mãe): - É, então vem cá. Deu um soco nele que daqui ele foi parar lá naquela cama. Minha mãe quando ela trabalhava ela forte, gorda.....Meus irmãos, quando minha mãe saia pra trabalhar ela pedia pra arrumar a casa. Ficava todo mundo na rua, na casa dos colegas, agora se nós subisse no telhado e visse que minha mãe vinha vindo lá do outro lado nego jogava a roupa dentro do armário, fechava com cordinha, colocava lixo debaixo do tapete, as louças dentro do fogão.

R: Disfarçava.

Cf: Minha mãe chegava: - Nossa como isso daqui ta limpo: - Ah vou pegar uma água que ta um calor, abria o fogão pra fazer comida, aquele monte de panela, depois ela mandava meus irmãos limpar tudo.

R: Mas sua mãe era brava?

Cf: Não, era legal

R: E ela mudou?

Cf: Sim.

R: Como ela está?

Cf: Ah, ela voltou a beber, antes ela não bebia, não fumava, ela trabalhava, agora não ta mais trabalhando, era gorda, forte, agora não é mais.

R: Essa mudança toda começou por que?

Cf: Quando ela começou beber.

$\mathrm{R}$ : Mas tudo isso veio..., o que aconteceu pra...você acha que aconteceram mudanças pra levar ela a essa situação!!?

Cf: Ah, quando ela conheceu meu padrasto, ela não fumava, não bebia.

R: Você lembra quando ela conheceu o U. (padrasto)?

Cf: Foi na rua, lá na pracinha.

R: Qual pracinha?

Cf: Aqui na Consolação, não tem a 3a Cia.?

R: 3 a o que?

Cf: 3o DP, ali não tem uma praça, perto de uma igreja? Então aquela praça ali que ela ficava. Um monte de bêbado lá.

R: Nessa altura ela já bebia?

Cf: Ela começou a ficar lá porque ela conheceu ele.

R: Nessa época ela tava separada do seu pai. E ela trabalhava? Vocês ficavam na rua mas ela trabalhava? 
Cf: Trabalhava.

R: Quem ia pra rua eram só os filhos? Ela trabalhava e mantinha a casa, e quem ia pra rua eram só os filhos, é isso?

Cf: Ela trabalhava e nós que ia pra rua, aí meu irmão começou usar droga, começou roubar, foi pra FEBEM, saiu, foi de novo, saiu e agora foi de novo, agora ta lá. Minha mãe ta indo no Fórum, esse mês que agora é o último mês que ela vai lá.

R: Tua mãe ta morando com quem agora?

Cf: Na casa dela.

R: Mas quem está morando com ela?

Cf: A E f 19, a N (sobrinha), a N. é filha da minha irmã a $E$.

R: Ah! ta, a N. é a neta dela então.

Cf: A N., o A. m, 9, não o A. mora com minha avó, o L.m. 2, a A. f. 5 e a S. f. 10.

R: Certo.

Cf: E o D. m. 13.

R: E o U. (padrasto) também ta morando lá?

Cf: Não.

R: Não..., mas vai encher o saco lá?

Cf:...

R: E a P. f. 25, o que está fazendo a P.?

Cf: Ela ta morando na casa do meu irmão.

R: Qual irmão?

Cf: O D.m 23.

R: O D., os dois estão morando juntos? A P. trabalha, ou não?

Cf: Agora eu não sei.

R: Faz tempo que você não vê ela?

Cf:...

R: O D. trabalha? Você sabe o que ele está fazendo?

Cf: Trabalha.

R: Com o que?

Cf:...???...

R: Ele se meteu em drogas, em roubo, ou ele ficou no caminho certo? Quer dizer num caminho sem..., não é certo ou errado.

Cf: Ele não fica na rua.

R: Não. Ele sempre foi de ficar mais assim estudando, trabalhando.

Cf: Ele trabalha e de noite vai pra igreja.

R: Ele é crente?

Cf: É. 
R: E a P.?

Cf: Não, ela não ta trabalhando não.

$\mathrm{R}$ : E ela é religiosa também, ou ela ia pra rua, mexia com droga?

Cf: Não.

R: Não. Como foi que ...

Cf: Só uma vez que ela foi pra rua, aí ela tava dormindo, perdeu o ônibus, aí veio o juizado levou minha sobrinha a sobrinha dela, aí ficou o maior tempo pra tentar pegar a menina, aí conseguiu pegar a menina.

R: Mas ela ficou na rua esse tempo?

Cf: Não, ficou em casa.

R: E a J.f. 21, o que é da J.?

Cf: J. mora na casa dela, ela trabalha num restaurante.

R: É casada?

Cf:...?...

R: Essa daí foi pra rua, usou droga?

Cf: Não, os únicos que foi pra rua foi eu, o D. m.13, a E. f. 19 e o E. m. 17.

R: A E.f.19, o E.m.17, você e o D. m. 13, a S. f. 10 é muito pequenininha e os outros A. m 9, A f. 5 e o L. m. 2, também são muito pequenos. A S. f. 20 , o que é da $\mathrm{S}$ ?

Cf: A S. também já foi pra rua.

R: E ela ta aonde hoje?

Cf: Ela ta na casa da sogra dela, ela tem dois filhos, o C. m. e mais uma menina que eu não sei o nome dela.

R: Ela ta casada!!!?

Cf: Não.

R: Não ta..., mas ta morando na casa da sogra . E a E. f. 19, o que está acontecendo com ela?

Cf: Ta na casa da minha mãe.

R: E o E. m. 17?

Cf: Ta na FEBEM.

R: Ta na FEBEM pelo que?

Cf: Aqui no farol da Cardoso, aí ele tava lá sentado fazendo rodinho, apareceu os polícia, tinha gente que tinha roubado no farol, pensaram que foram ele e como ele já tinha passagem levaram ele, aí colocaram mais droga em cima.

R: Você $\mathrm{C}$. ta aqui há quanto tempo?

Cf: Desde quando abriu essa casa. Desde o tempo da igrejinha.

R: Mas eu já vim aqui várias vezes e não lembro de você.

Cf: Eu to na casa desde quando abriu.

R: É!!? 
Cf: Antes não tinha esses educador.

R. É não tinha, era o O.(educador), a M. (educadora), a A. P. (abrigada)...

Cf: O T.(abrigado), a A. P. (abrigada), a R. (abrigada)...A. L. (abrigada)...

R. Gozado acho que a gente se viu pouco.

R. Você se lembra de mim?

Cf: ...? ?...

R. Então acho que a gente se desencontrou.

Cf: A G. (abrigada). Eu lembro quando você tava fazendo a entrevista com a G. no quintal.

R. Ah! Ta.

Cf: Nessa época minha irmã tava aqui na casa.

R. E você já passou pela FEBEM?

Cf: Não.

R. C. aqui essa conversa é entre nós. Você não precisa ter receio de se abrir. E de experiência com droga?

Cf:...com a droga...ó antes eu fumava só pedra..., depois eu parei, eu só cheirava cola e thiner e fumava maconha. Depois eu parei de fumar maconha e de usar thiner e só cheirava cola, agora não cheiro mais cola, agora eu só fumo cigarro.

$\mathrm{R}$ : $\mathrm{E}$ quanto tempo durou isso?

Cf: Faz muito tempo, quando eu cheguei na rua, quando eu comecei a ficar assim na rua mesmo era bem pequenininha, ...(ininteligível)..., era bem pequenininha, lá na igrejinha.

R: E quanto tempo durou essa sua passagem pela droga?

Cf: Nossa durou bastante. Desde os 10, não desde os 11 anos comecei a usar...

R: E como é que você diria que...

Cf: ....ininteligível...

R: E há quanto tempo você não usa droga?

Cf: Meu irmão? Ta na FEBEM.

R: Não, você, há quanto tempo ..., você começou com 12, tava fazendo as contas né, há quanto tempo você não usa?

Cf: Um mês.

R: Foi 12, 13, 14, 15, foram 4 anos. E como você diria que foi essa sua experiência com a droga? O lado bom e o lado ruim?

Cf: Primeiro, toda vez que você tava com ...? ...os policia batia em você, às vezes eles tava nervoso, qualquer coisa que acontecia na casa deles, ele descontava em nós, teve um policial, M., ficava lá na Augusta, uma vez ele pegou a D. (menor, f.) e bateu nela por causa que ele falou que tinha brigado com a mulher dele, aí ele bateu nela e deixou ela marcada, depois soltou ela, aí ela foi lá no Conselho Tutelar da R. pegou o nome dele e o número da viatura e deu lá pro tio C. de lá, aí ele pegou mandou pro outro Conselho Tutelar, aí mandaram pra 
delegacia onde ele trabalhava, aí ele foi mandado embora, aí depois ele voltou só que agora ele ta trabalhando em outra área.

R: E a droga..., como foi pra você?

Cf: Ah não foi muito bom não..., quando eu tava muito acostumada a usar...

R: O que não foi bom?

Cf: Por causa de droga na rua, minha mãe não conseguia achar nós.

R: Hoje ela sabe onde você está.

Cf: Aqui.

R: Você tem contato com ela..., ela sabe. E você..., o que era bom na droga?

Cf: Nada.

R: Nada!!!!? E você repetia por que? Alguma coisa devia ser bom pra você repetir.

Cf: Porque eu tinha acostumado muito a usar droga.

R: Você tem visitado a sua mãe?

Cf: Passei o Natal lá. Só o ano novo que não.

R: Por que você não fica com a sua mãe hoje? Você tem vontade ou não tem, ou qual...

Cf: Por que lá é muito pequeno, é só duas camas lá, e numa cama dorme a E. f. 19 e a N., filha da E. e a A f. 5, e na outra dorme minha mãe, D. m .13 e o L. m 2.

R: E a sua mãe está sem trabalhar?

Cf: Ela está atrás de emprego só que ela não consegue.

R: Por que?

Cf: ...

R: Ela parou de beber ou ainda ta bebendo?

Cf: Ta bebendo.

R: Ta muito magra?

Cf: Não ta muito não, mas ta.

R: Ta doente?

Cf: Não, só tem anemia e um ....?...na cabeça.

R: Você gostaria de poder morar lá com ela ou não?

Cf: Só que não dá certo, quando eu fico muito lá dá vontade de ir pra rua e quando eu to aqui e da vontade de ir pra rua eu vou pra lá. Aí quando eu to lá eu volto pra cá.

R: E como você se dá com suas irmãs?

Cf: Eu me dou bem com elas...

R: Suas irmãs, irmãos...

Cf: Eu me dou bem com elas.

R: Quem você gosta mais? 
Cf: Da A. f. 5, a A. e a J. f. 21.

R: O que você gosta mais? ... nas duas?

Cf: Ah! porque elas sabem compreender bastante assim..., a P. f. 25, também, agora tem os meus irmãos que você fala: - Ah..., não sei o que ta acontecendo comigo. Ah, porque não sei o que, começam a falar um montão. Agora a J. f. 21 não, ela é bem mais compreensiva. A A f. 5 . é a pior, ela é pequenininha mas só que ela é muito chata, ela é folgada, ela é que nem eu quando eu era pequena. A S. f. 10 já é mais jeitosa, ela tem mania de falar que nem gente grande. Às vezes eu dou um tapa nos meus irmãos e ela fala: - Você é quem pra bater neles? A minha mãe ainda não morreu, você ta entendendo? (risos). Eu olho pra cara dela, eu não agüento. Ela fala: - Deixa a minha mãe chegar aqui e você vai ver. Ta pensando que você é quem? Você vem de lá do abrigo pra vim bagunçar aqui? Você ta muito enganada, viu!!!! Aí eu olho pra cara dela e não agüento, eu começo a dar risada dela, ela: - Você ta dando risada de mim? Deixa a minha mãe chegar, deixa a minha mãe chegar, que você vai ver o que você vai levar. Às vezes eu levo cesta pra lá e tem bolacha, eu pego a bolacha e não dou pra eles, aí eles fica..., aí eles vem correndo: Dá uma pra mim. Aí eu falo: - Não você já comeu. Aí eles: - Ah, você não vai me dar né, ta bom. Aí ele vai lá dentro pega a vassoura e vem correndo atrás de mim. Aí eu falo: - Para moleque, para. E ele: - Você vai ver, você não vai me dar né? Aí ele liga a televisão e fica lá assistindo. Aí a mãe chega: - Ó mãe, abriu a cesta, pegou bolacha e não dividiu com ninguém. Minha mãe: - Vem aqui C...Você pegou bolacha? - Peguei e não dividi com ninguém, eles são muito zolhão. - Ah, agora você vai apanhar. Aí minha mãe me dá um tapa e eles fica todo alegre...

R: Você está estudando C.?

Cf: Não.

R: Você estudou?

Cf: Estudei até a quarta e vou voltar a estudar.

R: Aonde, lá no Padre?

Cf: Não acho que vai ser no CEMES.

R: O que é CEMES?

Cf: É como o mesmo lugar, só que atende gente que largou faz tempo, assim gente mais velha, de 60, 70.

R: E o que você vai fazer lá?

Cf: Vou estudar lá

R: No meio desse pessoal tão velho.

Cf: É por que essas escolas de agora elas não aceita gente de maior idade, que ta muito atrasada.

R: Mas no Padre não tem?

Cf: Não sei não.

R: No Padre V., na igreja, lá tem uma escolinha.

Cf: Não mas lá no CEMES é quase a mesma coisa. Mas tem pessoa nova também...Oh! a última vez que eu fui lá tinha um viadinho assim na minha sala né, ..., calcinha apertada, kanekalon, toda-toda, pior que ele sentava logo do meu lado, aí eu tava sentada na cadeira, conversando, daqui a pouco ele: - Vem cá, hoje eu vou no Shopping, tem cada mulher lá, meu Deus, não dá pra 
agüentar. Primeiro ele falava demais: - Se toca meu, se liga meu, presta atenção na aula. Ta louco.

R: E você vai pra que série agora?

Cf: Pra quarta. Porque lá é assim: primeira e segunda, terceira e quarta e a quinta e a sexta.

R: Você tem que terminar a quarta.

Cf: Tenho que fazer a terceira e a quarta.

R: São os 8 primeiros né? Vai do primeiro até o oitavo, é o primeiro grau.

Cf: Não é primário, porque faz a primeira e segunda junto, a terceira e quarta junto, a quinta e sexta e a sétima e a oitava.

R: E como você se dá com a escola?

Cf: Ah! é legal.

R: Você gosta do estudo?

Cf: Gosto.

R: Você acha que o estudo pode valer alguma coisa?

Cf: Vale. Se você não estudar você não vai aprender nada, se você não aprender nada você não vai trabalhar, ou então vai trabalhar na roça. Eu não sei escrever muito, mas sei, agora a J. (abrigada), a J. ta com 16 anos não sabe ler nem escrever.Quando vai ler ou escrever alguma coisa pede pra tia V.

R: O que você pensa fazer com os estudos?

Cf: Ah! eu quero trabalhar.

R: Você tem uma preferência de trabalho?

Cf: Eu quero ser professora de Educação Física.

R: Você gosta disso...

Cf: Educação física e matemática.

R: O que você acha interessante na Educação física e na Matemática?

Cf: Matemática é por causa das contas, eu acho legal fazer continha e a educação física por causa dos trabalhos, jogar bola...

R: E de namoro como é que é?... muito namorado...

Cf: Pouco.

R: Ta aonde?

Cf: Ta lá embaixo.

R: Ta muito tempo com ele?

Cf: Um mês.

R: E como é que foi antes, já teve muito namorado, pouco?

Cf: Não gosto de namorar não.

R: Não...

Cf: Com esses meninos aí não.

R: Como é isso? 
Cf: É porque...(ininteligível)...esses meninos mal toma banho, de vez em nunca, eles levantam o braço você é capaz de cair dura no chão, vem falar: - Ai amorzinho (risos). Agora tinha um menino que ele era muito chato, aí, ele não saía do meu pé. Os dentes dele era tudo cárie, agora quando ele escovava os dentes, ele ficava branquinho, não tem a propaganda da televisão que deixa o dente todo branco, o dente dele é assim, todo branco, eu acho o maior bonito quando ele escova o dente. Teve uma vez que eu levei uma pasta e uma escova pra ele, aí: - Você vai ficar comigo? - Ta bom, então vai escovar o dente - aí ele escovou, o dente ficou branquinho. Aí e agora? Agora você vai tomar banho, aí ele veio aqui na casa e tomou e ficou maior cheiroso..., ele fica nervoso comigo...

R: E com o namorado atual, como é, como você se sente?

Cf: Ele é muito chato. Ah eu to sossegada ele pega no pé, aí vem: Tó o rádio pra você escutar. ...Depois: - Que hora você vai levantar amanhã? Eu: - O mesmo horário de sempre. Aí ele fala assim, amanhã eu vou te dar a chave do armário ta. Aí ele vai e me acorda antes de ir trabalhar, aí ele me dá a chave do armário.

R: E você então vai começar a estudar e quais são os seus planos? Esse ano só vai estudar mesmo!!!?

Cf: Só vou estudar. Eu quero estudar pra ser alguém na vida... Às vezes me dá nervoso de algumas pessoas. A mãe cuida das pessoas desde quando nasceu, até os 18, 19 anos, aí quando a mãe fica doente ele coloca a mãe em qualquer coisa...

R: Por que você está pensando isso?

Cf: Não sei... É porque as vezes eu vejo na televisão, ... esses crimes..., vejo gente matando pai e mãe por causa de herança, gente colocando mãe e pai no asilo, me dá um nervoso isso daí. Você viu o caso daquela menina que chamou o namorado dela pra matar os pais dela pra ficar com a herança, aquela loira...

R: Muita ingratidão você acha...Bom C. já está na hora do almoço, vamos parar um pouco por aqui, aí eu queria voltar pra continuar. Posso voltar?

Cf: Pode.

R: Então vamos parar aqui. Obrigado ta.

Segunda entrevista:

R: Bom C. hoje é 7 de janeiro de 2004. C., me diga uma coisa, qual a experiência que você acha que foi marcante na sua vida?

Cf: Quando eu comecei a fazer curso de culinária e computação.

R: O que você sentiu?

Cf: Ah eu achei legal porque todo dia eu ia lá, não ficava mais na rua, não ficava mais no farol.

R: Aonde era?

Cf: Lá na Santa Cruz.

Cf: Eu saia daqui umas 6 horas, não umas 7 horas pra chegar lá às 9. Aí chegava aqui na hora do almoço. 
R: E você fez o curso todo?

Cf: Não.

R: Não deu pra aproveitar pra ganhar dinheiro com isso? Continuar?

Cf: Não.

R: Por que não deu?

Cf: Porque eu fiz ele quase todo sabe, quando chegou..., faltava duas semanas pra terminar, eu parei de ir, por causa dos passes da casa.

R: Parou de ir em qual? Culinária ou computação?

Cf: Culinária, que é tudo no mesmo lugar.

R: Mas você fez o de culinária...

Cf: É.

R: E tão pouco para acabar e não deu certo..., teve mais algum motivo? Será que você ficou meio perdida nessa época..., saiu pra rua e...

Cf: Não...

R: Eram só os passes mesmo...

Cf: Eles aproveitavam pra ir pra escola, só que quando eles iam passavam por baixo.

R: Mas o que você apreendeu, você..., podia ter aproveitado não?

Cf: Sei lá!!!!?

R: C. me diga uma coisa: - Na sua opinião, o que foi que sua mãe te deixou?

Cf: Ela não deixou..., meu padrasto morava lá..., nós brigava muito que ele ficava batendo na minha mãe. Por isso que eu e meus irmãos saímos de lá.

R: Sim..., eu digo assim que te deixou de exemplo, alguma coisa que ficou marcada da sua mãe, uma herança que ela te deixou mas não material, alguma coisa que você acha que tua mãe que te deu.

Cf: A educação.

R: O que você chama de educação?

Cf: Ah respeitar as pessoas, por mais que você tem negócio com uma pessoa você tem que respeitar.

R: Você acha que isso é a coisa mais legal que a tua mãe te deixou, mais importante...Qual sua opinião sobre sua mãe?

Cf: Ela é uma pessoa muito legal mas..., sei lá..., eu não consigo viver em casa com ela.

$\mathrm{R}$ : Você sabe dizer por que?

Cf: Por causa que sempre que eu to lá dá vontade de ir pra rua, direto quando eu vou pra lá eu brigo com minha irmã.

R: Qual?

Cf: A E. f. 19.

R: Vocês brigam por que? 
Cf:Ah, porque as duas ficam nervosas, não sei porque, ficam descontando nas pessoas.

R: Como você diria que sua mãe é de temperamento?

Cf: Ela é legal, ela vê as coisas e só fica guardando, guardando, aí quando ela não agüenta mais ela solta tudo.

R: Quando ela solta ela destrói as coisas ou não?

Cf: Não, ela só fala, fala, fala e sai.

R: E o seu pai, o que você acha que ele deixou pra você? Se é que ele deixou....

Cf: Eu nem ficava muito tempo com ele...eu nem ficava tempo com meu pai, ele ia trabalhar, quando ele voltava eu já tinha ido pra escola, quando eu voltava eu deitava e ia dormir..., ele era 'maior legal', ele brincava, levava nós pro clube, ficava contando estória pra nós de noite, ele era legal...

R: Como você descreveria o teu pai como pessoa...

Cf: Como assim...?

R: Ah quando você fala de alguém você diz - aquele sujeito é assim, é assado..., pensa assim, pensa assado.

Cf: Ele era muito legal, mas ele era muito alterado.

R: Alterado como?

Cf: Ele se irritava muito fácil.

R: E seu pai quando se alterava..., o que ele fazia?; batia?; xingava?

Cf: Não, ele gritava, brigava e saia pra rua.

R: Brigava só na palavra, no xingamento...

Cf: Ele discutia com nós, depois ia pra rua.

R: Não chegava a bater?

Cf: Não.

R: Ele ia beber?

Cf: Às vezes ele saia correndo (risos) pra cima de nós, aí nós saia correndo também.

R: Você diria que seu pai tem alguma coisa admirável?

Cf: Como assim?

R: Alguma coisa que você achava muito legal.

Cf: Ah! o jeito dele brincar com nós, contava estória, levava nós pra passear...

R: E alguma coisa condenável no teu pai? ; que você condenaria?

Cf: Quando ele bebia, quando ele fumava maconha.

R: E na tua mãe?

Cf: Quando ela bebe. Quando ela deixa meu padrasto ficar em casa.

R: Você teve na vida pessoas que marcaram a sua vida? Tanto amigo da tua idade, como gente mais velha.

Cf: Tinha um menino,...(?)..., sempre que..., eu ficava assim direto na rua, e ele sempre vinha pra conversar comigo, e eu conheço ele desde o Projeto Vida. Ele 
sempre vinha conversar comigo, às vezes eu brincava com ele, sempre quando eu tava nervosa.

R: Fazia o que?

Cf: Brincava..., conversava comigo pra eu não ficar nervosa.

R: Ele marcou você.

Cf: Era legal o jeito dele conversar com a gente, quando a gente tava triste, nervosa, ele vinha perguntar o que tava acontecendo.

R: Teve mais alguém?

Cf: O irmão dele, o irmão dele, a mãe dele era muito legal também, ela ta presa, ela e o L1, ... ontem ela ligou aqui lá da cadeia, ela tava sendo transferida e não sabia pra onde ia, era pra gente avisar pro L2.

R: Você tem contato com o L2?

Cf: Ele ta na rua..., ele tava aqui...

R: Como você diria que você é, que você sente?; tristeza?; vazio?; às vezes eufórica; às vezes brava, destrói...

Cf: Não eu sou bastante calma e às vezes tem algumas coisas que eu vejo, mas ai eu sento e fico no canto só parada, pensando, ou senão escrevendo, até passar o meu nervoso.

$\mathrm{R}$ : O que te deixa muito nervosa?

Cf: Às vezes quando as pessoas fala algumas coisas de mim sem saber..., às vezes se xinga eu nem ligo, pode xingar minha mãe, sei que minha mãe não é aquilo, uma coisa que eu não gosto é que xingue minha mãe de vaca..., é uma coisa que me deixa muito nervosa.

R: Que mais que você sente, que você pode dizer assim que você é, como você é..., você se deprime?

Cf: Às vezes eu fico assim..., às (começou a falar de maneira rápida)

R: Calma, fale mais devagar senão eu não vou entender.

Cf: Tem às vezes quando a gente fala alguma coisa pros educador, e aí o cara vai e comenta pra pessoa e..., a gente pedimos pra não comentar, isso dá um nervoso... a gente bota uma confiança naquela pessoa.

R: O que você acha dos homens em geral? Tem uma opinião sobre os homens?

Cf: Ah! tem alguns que são muito chatos, tem uns que é legal, tem uns que é compreensivo e tem uns que não dá pra aturar.

R: Você pensa em casar?

Cf: Não.

$\mathrm{R}$ : O que você pensa sobre isso?

Cf: Ah! acho que dá muito problema.

R: Que problema?

Cf: Ah você perde sua liberdade...

$\mathrm{R}$ : Você dorme bem?

Cf: Eu durmo. 
R: Você costuma sonhar muito?

Cf: ...

R: Não? Você lembra de sonhos ou você não sonha?

Cf: Eu lembro quando eu tinha uns 7..., 7, 9, 10, não dos 11 anos até os 12 eu sonhava que eu sempre caía de um prédio, aquilo nunca tinha fim. Eu sempre sonhava que eu tava num prédio, aí eu subia o elevador quando eu descia alguém me empurrava do prédio e eu sempre caía e nunca tinha fim, sempre quando eu ia chegar pra cair no chão eu acordava. Quando eu tinha 11 até os 12 anos, eu continuei sonhando isso, era sempre o mesmo sonho. Eu tinha medo de dormir.

R: Passou?

Cf: Quando eu completei 12 anos sumiu, parou.

R: Aconteceu mais alguma coisa nessa fase? Você mudou de casa?; Você foi pra rua?

Cf: Nós mudamos da casa onde nós estávamos morando e fomos morar lá em Diadema.

R: Quem que foi?

Cf: Foi todo mundo...

R: Seu padrasto também, o U.?

Cf: Não.

R: Mas o U. estava na casa onde vocês estavam? ; e aí vocês foram pra Diadema sem ele e foi quando parou o sonho.

Cf: Aí eu parei de sonhar.

R: Mas você vê uma ligação?; a mudança que foi nessa época, você mudou, deixou de conviver com o U. e os sonhos pararam.

Cf: Parou.

R: Você vê? Tem essa associação? Foi tudo mais ou menos assim em conjunto? Ta entendendo o que eu estou dizendo? O que eu estou querendo dizer fala pra eu saber se você entendeu.

Cf: É quando eu morava na mesma casa que ele eu tinha esses sonhos, agora quando eu fui pra outra casa e ele não foi, parou...

R: É...isso que eu estou perguntando se você...

Cf: Quando eu morava aqui do lado eu sonhava direto esse sonho, quando eu fui morar lá em Diadema, em Eldorado, eu parei de ter esse sonho. Eu tinha até medo de dormir.

R: Você tinha medo do U.?

Cf: Tinha.

R: Medo do que?

Cf: Por causa que ele batia na minha mãe.

R: E com você ele já ameaçou?

Cf: Ele sempre ameaçava nós dizendo que ia matar nos à noite. Aí eu ficava com medo de dormir por causa disso aí e por causa dele. - O que você ta me 
olhando? (lembrando), ah dá licença!!! Aí ele vinha assim pra cima de mim e eu descia pra casa da minha avó. Aí eu chamava minha avó, minha avó mandava ele embora.

R: Ele vinha pra cima de você pra que?

Cf: Sei lá!

R: Querendo abusar sexualmente ou bater?

Cf: Querendo me bater, em mim e meus irmãos, todo dia ele ficava batendo na minha mãe, nos meus irmãos....

R: Sexualmente ele atacava vocês?

Cf: Não.

R: Como você diria que é a sua avó?

Cf: Ah! ela é legal só que tem umas partes dela que é muito chata.

R: Qual parte?

Cf: Que às vezes some alguma coisa quando nós ta lá em casa e ela fala que é nós, só porque a gente ficou na rua.

R: Ela mãe da sua mãe?

Cf: É.

R: Você falou pouco dela nessa nossa conversa..., com quem ela mora?

Cf: Ela mora com a minha tia..., a casa é dela, só quem mora lá é minha tia P. e meus primos.

Entra alguém na sala a conversação é interrompida.

R: Então você estava falando da sua avó, você estava dizendo que sua avó mora com a sua tia; irmã da sua mãe?

Cf: Irmã da minha mãe.

R: Você conviveu com sua avó?

Cf: Sim..., é porque quando nós morava lá na casa da minha avó, tinha uma casa encima da casa da minha avó, onde nós morava, minha avó morava na casa de baixo...

R: E o seu avô, você conheceu?

Cf: Não.

R: E os avós por parte de pai, você conheceu?

Cf: Não.

R: Também não...Você conheceu só a avó, a mãe da tua mãe...

Cf: Da família do meu pai eu só conheci a mulher dele, a irmã dele e o irmão dele, que era o A. m., a V. f. e a S. f.

R: E o que é feito do A. e da V.?

Cf: É irmãos do meu pai.

R: Então mas eles estão vivos?; tão presos?; tão trabalhando? 
Cf: Ele tem os filhos e ele tem um monte de cavalos. Ele sempre ta lá brincando...

R: Lá onde?

Cf: Lá onde minha mãe ta morando.

R: A tua mãe conversa com ele?

Cf: Conversa.

R: E a tua tia, irmã do seu pai?; Você teve contato com ela? Ou é uma pessoa distante?

Cf: Ela morreu, a V. f...

R: Morreu do que?

Cf: Não sei, ela passou mal na casa dela, ela tava um pouco mal, mas nem parecia assim que ela tava doente, aí depois nós fomos pra onde nós ia, eu e minha mãe, aí quando nós voltamos pra casa, aí dois dias depois chegou a notícia que ela morreu.

R: E esse teu tio irmão do teu pai, você não teve muita convivência com ele!!!?

Cf: Não.

R: Os teus irmãos estudaram?

Cf: D $m$ 13, todos estudaram...

R: Você diria que você foi a que menos gostou de estudar?

Cf: Estudei até a quarta.

R: Sim, mas comparado com eles, ou não.

Cf: Não.

R: É igual?

Cf: Os meus irmãos depois que comia a merenda, fugia da escola, que antes a merenda era primeiro aí depois que subia pras aulas, aí eles comia e pulava o muro.

R: Iam lá só pra comer.

Cf: Aí depois eles iam pra rua. Aí eles faziam uma liçãozinha assim, eles esperavam na hora da saída, passava uma pessoa assim eles passavam a lição pro caderno deles e ia pra casa.

R: Ninguém gostava de ficar na sala de aula.

Cf: Eles dois não, agora eu assim quando comecei estudar eu gostava, mas depois eu comecei a ficar meio assim... Mas quando..., na primeira..., eu catei a mesma professora a A., ela era a babá dos meus irmãos, na segunda eu peguei ela de novo e na terceira.

R: Isso foi bom pra você!?

Cf: Ela explicava direitinho, agora na quarta série, eu peguei a professora I.

R: E como foi sua experiência com ela?

Cf: Ah! ela era legal, todo final de mês..., ó toda aula era um ponto no caderno, quando era o final do mês ela juntava todos aqueles pontos e via quem tinha mais ponto, aí tinha o primeiro, o segundo e o terceiro lugar, aí ela vinha e dava 
uma coisa pra nós, era sempre uma blusa, um short, uma calça, as vezes vinha aqueles radinho de 5 real...

R: Você costuma ver sua mãe de quanto em quanto tempo?

Cf: Uma semana sim, uma semana não.

R: Então você vê bastante..., de quem você sente saudade lá na casa dela?

Cf: Do meu pai, do meu irmão.

R: Qual irmão?

Cf: Do E. m. 17.

R: Mas nessa casa que você vai visitar, da tua mãe das tuas irmãs, de quem você gosta mais?

Cf: Gosto de todos, mas em quem eu sou mais apegada é no L. 2 m. e na A. 5 $\mathrm{f}$.

R: C. me diga uma coisa, qual seria a melhor coisa que poderia acontecer na sua vida?

Cf: Minha mãe ter uma casa melhor.

R: Aí o que seria?

Cf: Na casa que ela ta é muito pequena.

R: Se ela tivesse uma melhor você moraria com ela?

Cf: Moraria.

R: E qual seria a pior coisa que poderia acontecer pra você.

Cf: Minha mãe perder meus irmãos..., que o juiz está querendo tomar.

R: E você acha que ela ficaria como?

Cf: Ah! minha mãe ia presa e meus irmãos pro juizado.

R: Sua mãe iria presa?

Cf: É.

R: Mas por que motivo?

Cf: Não sei.

R: Então você ficaria sem sua mãe e seus irmãos...

\section{Entrevista dirigida.}

R: C. você conhece a estória do gênio da lâmpada? Dos 3 desejos?

Cf: Do Aladim?

R: É. Ele encontra o gênio, esfrega a lâmpada e pede 3 coisas e o gênio faz...Se você encontrasse e pudesse fazer os pedidos, que coisas você pediria?

Cf: Pediria uma casa pra minha mãe..., que meu irmão saísse da FEBEM... e que a dona M. (mãe de seus amigos) saísse da cadeia. 
R: Dona M... Essa que você falou agora pouco, mãe desses dois rapazes que são legais...Você tem contato com eles assim? Quando a M. tava solta você ia na casa dela?

Cf: Eu morava lá.

R: Morava aonde?

Cf: Lá na casa deles.

R: Você não me contou essa estória.

Cf: Quando eu namorava com o filho dela.

R: Você chegou a morar com ela.

Cf: Lá era uma pensão, tinham vários quartos, aí subia a escada e tinha o quarto dela, aí do lado de cá morava eu e o filho dela, e aqui morava ela, o J. V. m., o G. m. e o C., só que toda hora tava mudando, era a maior bagunça.

R: Mas você morou com o L. 1 assim como se estivesse casada?

Cf: É.

R: Ah! foi....!!? Vocês tinham um quarto só de vocês. Que idade você tinha?

Cf: 14 .

R: 14 , a mãe dele convivia com vocês como se vocês fossem marido e mulher...

Cf: Não ela me tratava como se fosse uma filha.

R: Sei, mas você dormia na mesma cama que ele, como dois adultos.

Cf: Ninguém dormia direito, ficava a noite inteira andando, dormia de manhã e à tarde...

R: Mas vocês eram namorados.

Cf: Tava hoje de vez em quando eu escrevo pra ela. Eu tava escrevendo pra ela agora pra saber qual o local que ela foi transferida.

R: Sei...Se você ganhasse uma ilha, pra você sozinha, quem você levaria pra morar com você?

Cf: Minha mãe, meus irmãos...

R: Quais irmãos?

Cf: D. m. 23..., todos.

R: Todos?

Cf: Levava minha mãe, meus irmãos, L. 1, o C. m., a dona M.

R: Que são amigos...E quem você não levaria de jeito nenhum?

Cf: Meu padrasto..., não levaria a P. f.

R: Qual P.?

Cf: Uma menina que morava lá perto de casa.

R: Por que você não levaria ela?

Cf: Porque ela é muito chata.

$\mathrm{R}$ : Como ela é chata?

Cf: Ela fala muita coisa que ela não sabe. 
R: Ela fala coisas de você?

Cf: De mim, da minha mãe, dos meus irmãos, coisas que ela não sabe.

R: Sei..., deixe eu ver se eu tenho mais uma pergunta pra te fazer hoje...Como você acha que vai ser sua vida quando você for adulta?

Cf: Eu quero estudar e trabalhar, quero ser professora de educação física e de matemática.

R: E como você vai morar? Você vai morar sozinha, você já disse que casamento pra você é uma coisa que você não gosta muito né?. Como você pensa que vai viver assim, com companhia de pessoas?; como seria?

Cf: Sozinha acho que não, com alguém. Mas casar não, sei lá, eu não gosto disso.

R: E filhos, você pensa em ter?

Cf: Dois.

R: Homem, mulher?

Cf: Um homem e uma mulher, quando eu tiver vinte e não sei quantos anos.

$\mathrm{R}$ : E como você gostaria que fossem os seus filhos?

Cf: ...?...(ininteligível).

R: Como você se sente na sua vida sexual? Você se sente à vontade?; se sente envergonhada?; você gosta?; você não gosta?

Cf: Primeiro eu fico com vergonha.

R: Mas é muito intenso, mais ou menos? Por que tem gente que fica tão envergonhado que até desiste né. (risos). Tem gente que sente uma vergonha que é normal, tem gente que é descarado, faz as coisas na frente dos outros.

Cf: Nossa...Uma vez eu vi isso aí no salão.

R: O que você viu?

Cf: Uma vez vieram me chamar pra ir pro salão, aí eu cheguei lá no salão, tava havendo um concurso lá de..., um negócio lá..., a gente tava lá né se divertindo, aí nós sentamos num banquinho lá e ficamos, aí daqui a pouco o pessoal sobe lá no palco e começa a fazer amor na frente de todo mundo, eu peguei e saí pra fora ... falei pras minhas amigas: - Tchau pra vocês to indo embora. Aí eu peguei minha bolsa na portaria, peguei minha bolsa e vim embora...

R: Certo...C. se você ganhasse na loteria, muito dinheiro, o que você faria, como você usaria esse dinheiro.

Cf: Dava uma casa pra minha mãe e o resto eu guardaria pra mim.

R: E como você gastaria pra se divertir, o que você faria pra se divertir?

Cf: Fácinho. Ia pro Play Center. Não ia pro Hoppy Hary.

R: E você guardaria o dinheiro como?

Cf: Guardaria no banco pra eu usar quando fosse maior.

R: E como você usaria esse dinheiro?

Cf: Usaria comigo mesmo, comprava uma casa pra mim, ficava quieta no meu canto.

R: E me diga como é que você se sente aqui? 
Cf: Ah! é legal. Melhor do que ficar na rua.

R: Você se dá bem com as pessoas aqui?; Como é sua relação com elas?

Cf: Ah! eu me dou bem com as pessoas.

R: Bom, então acho que por hoje a gente encerra. Você quer falar alguma coisa, perguntar alguma coisa?

Cf: Você gosta de ser psicólogo?

R: Gosto, eu me divirto com isso, em conhecer as pessoas, em saber como elas pensam, em saber por que elas sofrem.

HTP e desenhos livres.

R: Então C. hoje é 8 de janeiro de 2004. C. hoje na nossa conversa, eu queria que você fizesse uns desenhos pra mim, é apenas pra você se expressar, eu não vou avaliar se você sabe desenhar, se é bom, se ta bonito se ta feio, é apenas o teu desenho como expressão tua, das tuas coisas, então isso é o que importa, não precisa ser um belo desenho, aqui você tem lápis coloridos, borracha, você tem tudo aí e você usa como quiser. Então o primeiro desenho que eu queria que você fizesse é um desenho livre, pode desenhar o que você inventar.

R: Então C. eu queria que você me contasse uma estória desse desenho.

Cf: É uma casa, tem um lugar...., aí tem uma casa que ela é amarela, tem duas pessoas que mora lá, um homem e uma mulher. Do outro lado tem um rio, um monte de peixe e lá tem mais duas casinhas, lá ..., bem lá no fundo.

R: Me mostra aí no desenho.

Ela mostra.

Cf: Tem um pé de fruta, de uva e dois anjinhos olhando lá em baixo, o sol bem claro, eles lá conversando, os peixes nadando, as flores nascendo...

R: Esse lugar, na tua imaginação, é o que?

Cf: É um lugar de paz.

R: É um lugar que você queria encontrar? Você acha que ele existe?

Cf: Existe.

R: Depende do que pra chegar nesse lugar?

Cf: Paz, amor e compreensão...

$\mathrm{R}$ : De quem?

Cf: De todo mundo...esse lugar é a felicidade.

R: Esse lugar é a felicidade...!!! O que falta pra se encaminhar pra esse lugar, pra ir chegando nesse lugar?

Cf: Largar as drogas, ter paz e amor no coração e aceitar Deus...

R: Aceitar o que?

Cf: Aceitar Jesus...

R: E essas pessoas que moram aí, quem são? 
Cf: Jesus e Maria.

R: Tem alguma coisa de ruim nesse lugar?

Cf: Não.

R: Não, nada, tudo é bom...!!!? Você acha que pra chegar nesse lugar falta muito?

Cf: Aí é que eu não sei.

R: Você conhece gente que já viveu nesse lugar?

Cf: Eu não...

R: Não conhece...então ta bom..., quer falar mais alguma coisa?

Cf: Não.

R: Então C. eu queria que você fizesse outro desenho agora, queria que você desenhasse pra mim uma casa.

Cf: Só uma casa?

R: Só uma casa, do jeito que você quiser.

R: Conta uma estória sobre essa casa. Quem mora nessa casa?

Cf: Ninguém, ela está sendo alugada.

R: Está pra alugar, está vazia. De quem ela era? De quem ela é?

Cf: De quem ela é?......Dr. Marcos.

R: Quem é o Dr. Marcos?

Cf: Um cientista.

R: Um cientista...E o que ele faz? De trabalho...

Cf: Não sei, não conheço ele.

R: Ele é da tua imaginação ou ele é de verdade? ...O dr. Marcos existe como pessoa ou é só da sua imaginação?

Cf: Da minha imaginação.

R: Da tua imaginação... Morava alguém nessa casa?

Cf: Ele.

R: Ah ele mesmo.

Cf: Só que ele vai alugar essa casa que ele tem outra.

R: Ah ele saiu dela e ela está vazia. E por que ele saiu dela?

Cf: Porque ele tem outra.

R: Sim...

Cf: A outra é maior...

R: É a outra é maior.

R: E como foi a vida dele enquanto ele morou aí?

Cf: Tinha muito fotógrafo por aí e por isso ele ficava escondido...

R: Ficava escondido...

Cf:E todo mundo quer comprar a casa dele, porque ele é muito famoso. 
R: Ele é muito famoso e aí a casa dele ficou cobiçada por causa da fama.

Cf: Todo mundo quer comprar.

R: E o que ele fazia que dava tanta fama pra ele?

Cf: Porção mágica...

R: De fazer o que?

Cf: De crescer cabelo...

R: (risos) Os carecas que faziam fila...Que mais...

Cf: Era de crescer cabelo.

R: E o Dr. Marcos ganhou dinheiro com isso?

Cf: Ganhou..., todos os carecas iam lá...

R: E ele comprou a outra casa com esse dinheiro...

Cf: Todo mundo cortava o cabelo, os cara ficava enfezado, não gostava e ia lá.

R: Ele resolvia qualquer problema de cabelo...E ele morava com quem aí?

Cf: Com ninguém, a família dele morreu.

R: Ele era sozinho.

Cf: A mulher dele foi cortar o cabelo acabou cortando a cabeça dele.

R: Por que fizeram isso?

Cf: Porque ela não viu que não tava cortando o cabelo direito. Ela cortou a cabeça estourou a veia...

R: Mas eles eram tristes pra querer morrer assim...

Cf: Eles eram muito felizes.

R: Eles eram felizes.

Cf: Só sobrou um filho dele.

R: Sobrou um filho..., quem é esse filho?

Cf: Ele trabalha numa empresa.

R: Com o que?

Cf: Coca-cola.

R: Coca-cola. Por que esse sobrou?

Cf: Por causa que quando eles foram cortar o cabelo, ele não tava lá, ele tava na rua, jogando bola.

R: E a relação deste com o pai era diferente da dos outros?

Cf: Antes ele gostava do pai dele, hoje não.

R: O que mudou?

Cf: Que ele pensou que foi culpa do pai dele os outros morrerem.

$\mathrm{R}$ : E quem foi que morreu?

Cf: Foi a mulher e uma criança.

$\mathrm{R}$ : De quantos anos?

Cf: Cinco meses. 
R: Cinco meses. Mas ele se dava bem com a mulher?

Cf: Sim.

R: E como é que ele ficou depois disso, da morte da família?

Cf: Ficou muito triste, já queria mudar daí agora ele mudou de vez.

R: Ele já mudou...E como ele está vivendo nessa outra casa?

Cf: Ele continua fazendo as mesmas coisas mas ele está triste.

R: Está triste...ele não se conformou que a mulher morreu..., que o outro filho morreu...

R: E por que você acha que cometeram um erro desse tão trágico como esse, cortar a cabeça, cortar o cabelo errado, cortar a veia e morrer?

Cf: Porque eles queriam cortar o cabelo e fazer crescer de novo...

R: Você quer contar mais alguma coisa sobre essa casa? ...A casa era feliz? Faltava alguma coisa nessa casa? O que tinha de melhor dentro dessa casa?

Cf: A família dele...

R: Bom..., agora eu queria que você me desenhasse uma árvore.

R: Que árvore é essa?

Cf: É uma macieira.

R: Macieira... Ela ta saudável?

Cf: Ta.

R: Ta com saúde.

Cf: Ta.

R: Aonde ela esta localizada?

Cf: Atrás da casa do cientista.

R: Do dr. Marcos?

Cf: É.

R: E a quem ela serve?

Cf: Como assim?

R: Alguém deve se alimentar dela, ou não.

Cf: Todo mundo que passa por lá.

R: Todo mundo..., até quem não é da casa..., ela não está nem cercada por um muro?

Cf: Não.

R: Tem a casa, a macieira, as pessoas passam e se servem...

Cf: A macieira fica atrás da casa, só que um pouco pra lá...

$\mathrm{R}$ : $\mathrm{E}$ quem é que se serve dessas maçãs?

Cf: Todo mundo que passa pela avenida.

R: Quantos anos tem essa árvore?

Cf: Quatro anos. 
R: Quatro anos...Quem plantou a árvore?

Cf: Foi um menininho que passou por lá.

$\mathrm{R}$ : E o que vai ser dessa árvore?

Cf: Vai morrer...

R: Vai morrer com quantos anos?

Cf: Primeiro ela vai murchar..., depois ela vai nascer de novo, vai dar fruta, vai envelhecer, vai murchar...

R: E vai morrer ou não?

Cf: Não, ela não morre.

R: Fica só envelhecendo, murchando?

Cf: Perdendo... depois nascendo de novo.

R: E sempre dando fruto...Ela está sozinha aí nesse espaço?

Cf: Ta.

R: O que ela sente? Como ela se sente?

Cf: Sozinha, mas ela gosta de ficar assim. Porque tem muitas pessoas que passam por lá, sentam debaixo dela, conversa.

R: Ela se distrai.

Cf: Sim.

R: Do que ela sente falta?

Cf: Das crianças, as crianças tão crescendo...

R: As crianças estão crescendo e ela sente falta das crianças... Os adultos tratam ela diferente?

Cf: Um pouco...

R: Como?

Cf: Fazendo coisa de mal debaixo dela.

R: E como é que as crianças faziam que ela gostava?

Cf: Brincava.

R: Quer falar mais alguma coisa?

Cf: Não.

R: C. me desenha agora uma pessoa.

Cf: Uma pessoa...

R: Quem é essa pessoa?

Cf: É um menino, empinando pipa, normal.

R: Qual o nome?

Cf: Davi.

R: Quantos anos ele tem aí?

Cf: 13.

R: A onde ele está? 
Cf: No campo.

R: É perto da tua casa?; é longe?

Cf: Perto da minha casa.

R: E por que ele está aí?

Cf: Porque ele gosta de empinar pipa.

R: Qual a idade dele?

Cf: 13.

R: 13 anos... Como é que ele está se sentindo?

Cf: Legal.

$\mathrm{R}$ : O que ele sente falta?

Cf: De nada.

R: De nada...! O que esse menino tem de bom?

Cf: Ele sente falta do meu irmão, o E. m. 17.

$\mathrm{R}$ : E o que deixa ele..., qual o temperamento dele?

Cf: É bom.

R: Bom...O que ele tem de bom, de positivo?

Cf: Minha mãe, meus irmãos, eu, minha família.

R: Ele está saudável?

Cf: Ta.

$\mathrm{R}$ : $\mathrm{E}$ o que vai ser desse menino?

Cf: Ele vai estudar, vai crescer, vai trabalhar e vai ajudar minha mãe.

R: Ele vai casar?

Cf: Vai.

R: Vai ter filhos?

Cf: Dois.

R: E ele vai ser o que de profissão?

Cf: Jogador de futebol.

R: O que você mais gosta nele?

Cf: Tudo.

R: E o que você não gosta nele?

Cf: Quando ele fica nervoso.

R: Como é quando ele fica nervoso?

Cf: Ele não fala com ninguém.

R: Se isola. Mais alguma coisa? A gente está no fim já. Me desenha agora uma pessoa do sexo oposto.

Cf: Como assim?

R: Do outro sexo. 
Cf: Uma menina?

R: É.

R: Quem é essa menina aqui?

Cf: É colega do meu irmão.

R: Qual o nome dela?

Cf: Natasha.

R: Natasha. Quantos anos a Natasha tem?

Cf: 12 .

R: O que ela está fazendo aí?

Cf: Chamando meu irmão pra jogar bola.

R: Qual é a brincadeira que ela gosta mais?

Cf: Empinar pipa.

R: Empinar pipa. Como é que ela se dá com seu irmão?

Cf: Bem.

R: Bem... O que ela pensa $d . .$.

C. Ela tem uma bola e ele tem a pipa, ela gosta de empinar pipa e meu irmão gosta de bola.

R: Aí um troca com o outro e os dois se divertem. O que ela pensa do teu irmão?

Cf: Que ele é legal.

R: E o que o teu irmão pensa da Natasha?

Cf: Que ela é uma menina muito simpática.

R: Eles se namoram?

Cf: Não.

R: Querem se namorar? Se gostam assim e não tem coragem de falar um pro outro?

Cf: Não é só amizade.

R: Só amizade mesmo. E como essa menina se sente na vida?

Cf: Muito feliz.

R: Ela tem família?

Cf: Tem.

R: E a família como é?

Cf: É legal.

R: Tem pai e mãe, ou só pai ou só mãe, como é?; irmão?

Cf: Tem pai e tem mãe e tem um irmão.

R: E o ambiente na casa da família dela, como é?

Cf: É legal.

R: É bom. 
Cf: Ela não gosta que o irmão dela não chama ela pra sair, só o Davi chama ela pra brincar.

R: Ah o irmão não chama, só o Davi. Ela se sente um pouco sozinha com o irmão?

Cf: Se sente.

R: Ela ta saudável?

Cf: Ta.

R: E o que ela vai fazer na vida? O que vai ser dela?

Cf: Ela vai ser professora.

R: Professora...Vai casar?

Cf: Vai.

R: Vai ter filho?

Cf: 4.

R: 4. Homem, mulher?

Cf: Dois homens e duas mulher.

R: E ela vai viver bem com o marido?; vai se separar?

Cf: Vai viver bem.

R: E como ela se sente fisicamente? Ela gosta dela, ela se sente bem?

Cf: Gosta.

R: O que ela acha dela mesma?

Cf: Ela acha ela o máximo.

R: Bom C. o último desenho, eu queria que você me fizesse um outro desenho livre

R: Então me conta sobre esse desenho, onde é esse lugar?

Cf: É a casa do palhaço.

R: A casa do palhaço. A onde fica essa casa?

Cf: No sul.

R: No sul da onde ? Do nosso país?

Cf: Santo Amaro.

R: Ah, Santo Amaro. Com quem que ele mora aí?

Cf: Com a mulher dele.

R: É essa aqui? (aponto para o desenho).

Cf: É.

R: E ele vive a vida de palhaço...Como é viver uma vida como palhaço?

Cf: Ah! ele deixa as pessoas feliz. As pessoas vem e ele brinca.

R: E o que a mulher pensa dele? Como ela se sente com ele?

Cf: Ela acha que ele tem jeito de palhaço...

R: Mas isso é bom ou é ruim pra ela? 
Cf: Pra ela é bom.

R: É bom. Quantos anos ele tem?

Cf: 37.

R: E ela?

Cf: 29.

R: Eles tem filhos?

Cf: Não.

R: Não tem. Eles vão querer ou não?

Cf: Por enquanto não.

R: Por enquanto não. O que falta nessa casa deles aí? O que falta pra eles?

Cf: Nada.

R: Nada. Você diria que eles são felizes?

Cf: São.

R: Por que eles são felizes?

Cf: Porque eles moram numa casa bonita, ele trabalha, ela também, porque eles gostam disso.

R: E ela trabalha com o que?

Cf: Com ele.

R: Ela também é palhaça!!!!? E tem alguma coisa que um não gosta no outro?

Cf: Não.

R: Não?

Cf: Quando eles briga.

R: E por que motivo eles brigam?

Cf: Besteira.

R: Quer falar alguma coisa a mais? Ta bom C. ta ótimo, gostei bastante. Por hoje é só, aí eu queria encontrar mais um dia pra falar com você. Tchau. 


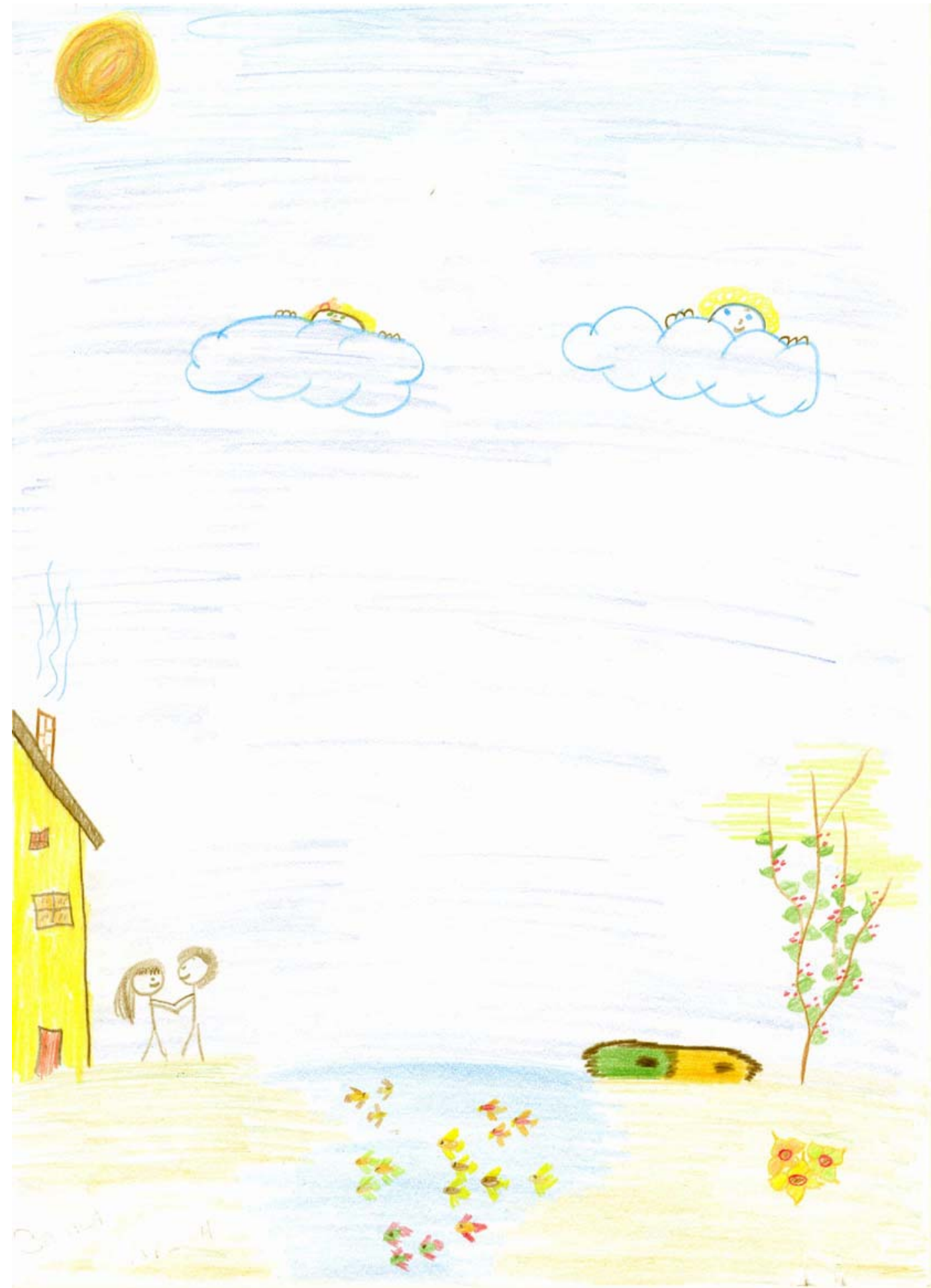




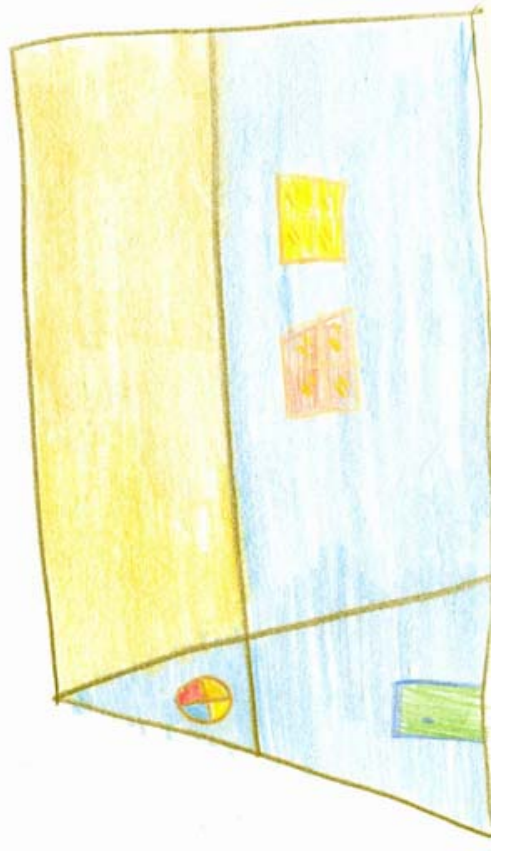




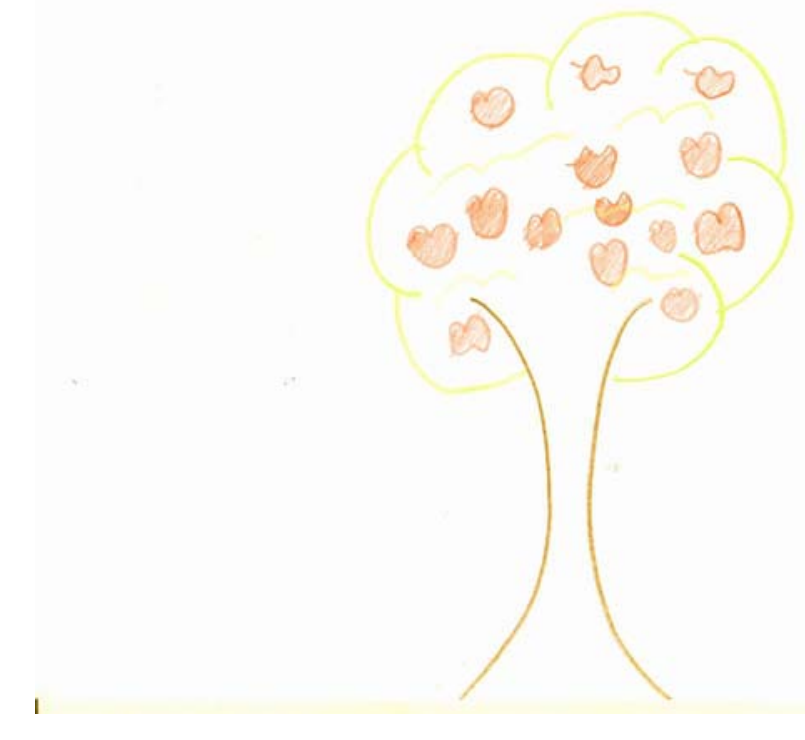




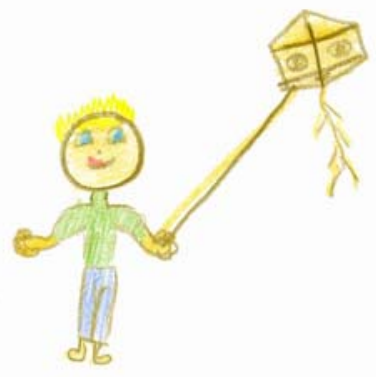




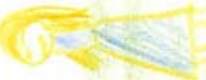

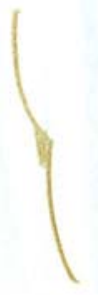

$\underbrace{1}_{4}$
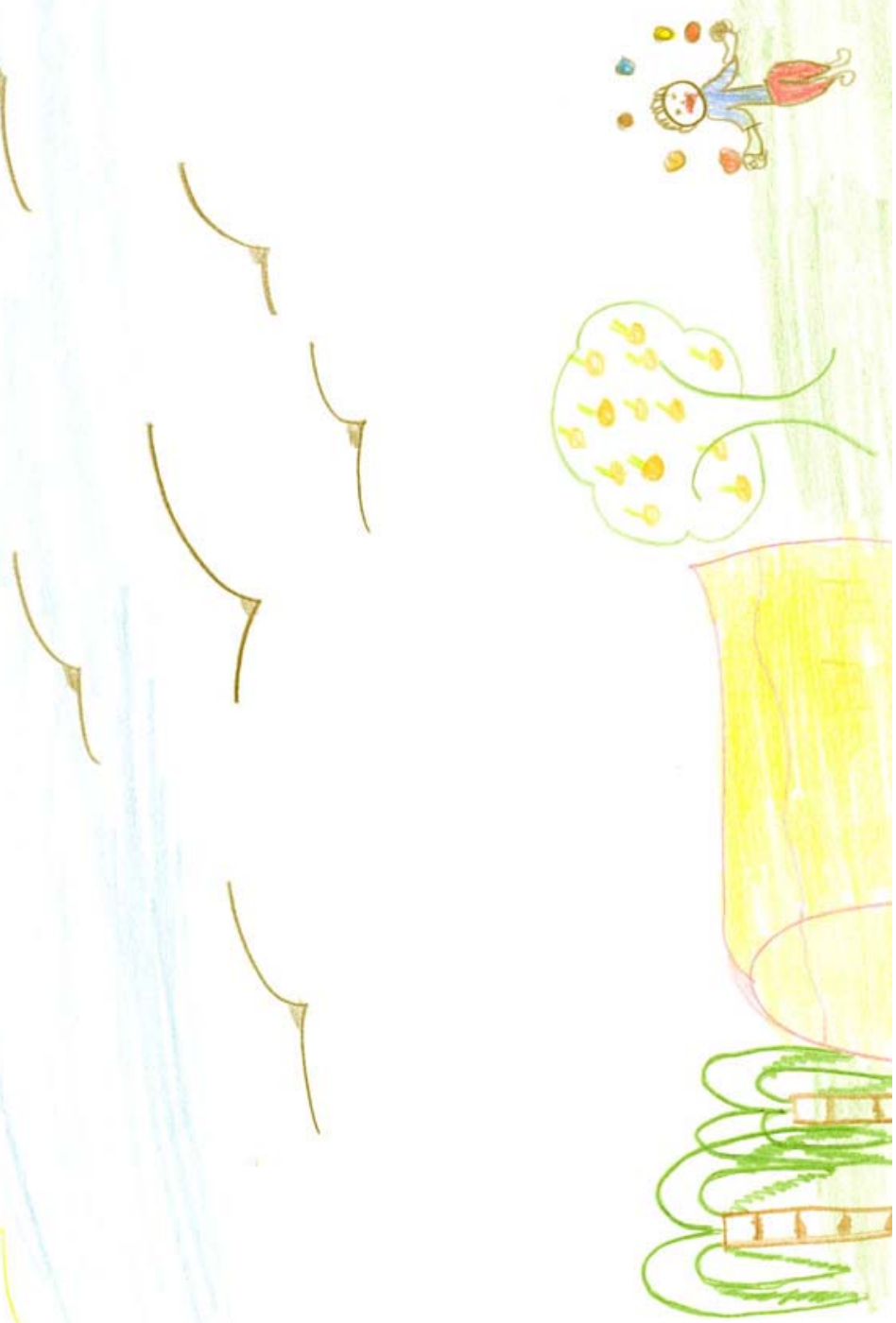
R: Bom dia C. 10 de janeiro de 2004, hoje deve ser a última entrevista da gente, então eu vou apresentar pra você umas pranchas com umas figuras, e aí eu quero que você olhe e imagine, deixe sua imaginação solta, como se fosse uma escritora e você vai contar uma estória sobre o que você esta vendo, o que as pessoas estão sentindo, como aquela situação se criou, como ela vai terminar, entendeu?

Bom, vamos lá, prancha 1, o que você vê aqui?

Cf: Um menino..., ele ta lendo um livro, livro de estória, ele gosta muito de ler estória, aí ele senta numa mesa, lugar bem sossegado e fica lendo....

R: Sobre o que fala esse livro?

Cf: É um livro de luta.

$\mathrm{R}$ : Luta, que tipo de luta?

Cf: Kung-fu.

R: Kung-fu.

Barulho no local, C. fala mas não é possível entender.

R: E ele está aonde?; na casa dele? noutro lugar?

Cf: Na casa dele.

R: É a casa dele!!! E o que aconteceu antes de ele ir até aí?

Cf: Ele tava brincando lá no campo.

R: Brincando de que?

Cf: De pega-pega com o irmão dele.

R: E daí?

Cf: Daí a mãe chamou ele pra almoçar, depois do almoço ele foi lá pra sala e começou a ler.

R: Depois que ele ler esse livro o que vai acontecer?

Cf: Aí o pai dele vai colocar ele numa sala e ele vai aprender a lutar Kung-fu.

R: Aprender a lutar Kung-fu...Quer falar mais alguma coisa?

Cf: Não.

R: Vamos pra outra prancha. Prancha 3MF. O que você vê aqui?

Cf: Ele lutou e se machucou e a mãe dele está chorando na porta.

R: Por que ele se machucou?

Cf: Porque estava lutando.

R: Sei mas ele foi descuidado?; alguém...

Cf: Foi dar um chute no alto, caiu no chão e se machucou, quebrou o braço. 
R: Descuido dele. Ele mereceu, ele tinha feito alguma coisa que merecesse castigo ou foi só falta de habilidade dele...

Cf: Falta de habilidade dele.

R: E a mãe viu isso tudo? Como é que ela soube ?; como é que ela ta?

Cf: Ela soube quando o menino veio do hospital com o braço machucado.

R: Então ele está na casa dele aí? E ela ta aonde agora?

Cf: Na porta.

R: Na porta do que?

Cf: Do quarto dele.

R: Ta olhando pra ele ou ta saindo?

Cf: Ela ta entrando.

R: Entrando...E o que ela está imaginando?; o que está se passando dentro dela nesse momento?

Cf: Nervoso. Ela não quer que o filho dela vai mais lá fazer luta.

$\mathrm{R}$ : O que ela pensa do braço quebrado, é muito grave?

Cf: Ela pensa que é um perigo, que o menino pode se machucar mais.

R: É um perigo...E como vai terminar essa estória?

Cf: Ele vai parar de lutar e eles vão ficar na casa deles.

R: Vai acabar tudo bem, só que ele vai ficar frustrado. Quer falar mais?

Cf: Não.

R: Prancha 7RH. E aqui o que você vê?

Cf: Aqui o menino cresceu e aqui é o pai dele.

R: É o mesmo menino?

Cf: É.

R: E o que está acontecendo aí?

Cf: Eles estão conversando.

R: Sobre que assunto?

Cf: O pai dele ta falando pra ele: - Agora que você cresceu você pode voltar a lutar. Aí ele fica meio assim, porque a mãe dele falou que não era pra ele ir e agora o pai falando pra ele ir. Ele não ta muito a fim de lutar de novo, a ultima vez ele se machucou, aí o pai dele fala pra ele: - Não agora vai ser diferente, eu vou estar lá pra te ver, pra te ajudar. Aí ele pega e aceita.

R: Ele aceita. E como vai terminar?

Cf: Aí eles vão lá, aí ele aprende a lutar, aí ele conta pra mãe dele e a mãe dele fica nervosa, terminou com o pai dele, pega o filho dela e vai morar bem longe.

R: Eles se separam. Porque o pai queria que ele lutasse e a mãe não queria, e aí deu essa separação.

Cf: É separaram por causa disso.

R: Mais alguma coisa? 
Cf: Não.

R: Como é o temperamento desse filho?

Cf: É normal, só que ele fica dividido entre o pai e a mãe

R: Fica dividido entre o pai e a mãe. De quem ele gosta mais?

Cf: Dos dois.

R: O que ele acha do pai?

Cf: Acha o pai dele legal mas muito insistente.

R: Insistente. E o que ele acha da mãe?

Cf: A mãe dele é mais calma mas também não quer que ele se machuque.

R: Algo mais?

Cf: Não.

R: 8 RM. O que você vê aqui?

Cf: Aí lutou, se machucou e está no hospital.

R: É ele que está aí no hospital. E o que está acontecendo aí no hospital?

Cf: Fazendo transplante nele porque ele se machucou muito, tem que fazer um transplante de rim.

R: Foi sério então o machucado?

Cf: Foi.

R: Que mais você vê nesse quadro?

Cf: Aqui é o filho dele.

R: É o filho dele!!! Então ele já tem um filho aí nessa época. E o que está acontecendo com o filho?

Cf: Ele ficou nervoso, aí ele quer lutar pra descontar no cara que fez isso com o pai dele.

R: Vingança...E então aqui é um hospital e ele está sendo operado pra fazer um transplante pra salvá-lo da luta...É isso...E o filho que ta aqui espera se vingar...E como vai acabar a estória?

Cf: O filho dele vai pensar bem e não vai mais fazer isso e o pai dele vai melhorar.

R: Vai se salvar.

Cf: Ele vai ficar assim um pouco mal.

R: Ta...Prancha 9RH. O que você vê aqui?

Cf: Os cara tudo dormindo, sossegado e aqui é o filho dele, só olhando.

R: Filho de quem?

Cf: Do homem.

R: Qual homem?

Cf: O Marcos.

R: O Marcos. Qual Marcos?

Cf: É o que estava sendo..., pai do Rafael. 
R: Quem é o Rafael e quem é o Marcos?

Cf: O Rafael ta lá e o Marcos ta aqui.

R: O Marcos é o pai ou é o filho?

Cf: Marcos é o pai.

R: E o filho é o Rafael, então quem é esse que ta olhando?

Cf: É o Rafael.

R: Ah ele ta olhando. E quem são essas pessoas?; a onde eles estão? de onde eles vieram?; pra onde eles vão? que lugar é esse?

Cf: Eles estavam capinando o mato e agora tão descansando.

R: Eles trabalharam muito!!!!? E eles estão a onde?

Cf: Estão numa grama.

R: E essas terras são de alguém?

Cf: São da mãe do Marcos.

R: Da mãe do Marcos...E eles estão capinando pra plantar alguma coisa?; ou só pra tirar o mato?; pra espantar cobra?; pra que?

Cf: Pra plantar.

R: O que vai ser plantado?

Cf: Legumes..., beterraba, cenoura...

$\mathrm{R}$ : E como é que vai acabar essa estória?

Cf: Eles vão continuar plantando e depois vão ser despedido porque não fizeram o trabalho bem feito.

R: Quem vai ser despedido?

Cf: Os 3, ele, ele e ele.

R: E o pai do Marcos ta aí?

Cf: Não.

R: Só ta o Rafael... Mais alguma coisa?

Cf: Não.

R: Prancha 13 HF. O que você vê aqui?

Cf: O Rafael, ta no quarto da mãe dele, só que a mãe dele tem um problema no coração e desmaiou, aí ele ta chorando.

R: E o que ele ta fazendo alem de chorar?

Cf: Ele ta chorando e pensando em chamar o pai dele, só que ele ta com medo que o pai dele pense que foi culpa dele e querer bater nele.

R: E ele fica muito tempo nessa indecisão?

Cf: Fica.

R: Quanto tempo ele fica pra tomar uma atitude?

Cf: 15 minutos.

R: Que atitude que ele toma? 
Cf: Ele corre pra chamar o pai dele.

R: E o que o pai faz?

Cf: Corre pra ajudar a mãe dele.

R: E o pai responsabiliza ele?

Cf: Sim.

R: Dizendo o que?

Cf: Fala pra ele por que ele fez isso, aí ele fala que não foi ele, conversa com o pai dele e o pai acredita nele.

R: E o que ele poderia ter feito pra causar o mal pro coração da mãe?

Cf: Tava conversando com a mãe dele que ele ia lutar.

R: Ah ele podia causar um desgosto pra mãe, é nesse sentido. E como vai terminar a estória?

Cf: Ela vai pro hospital, vai melhorar.

R: Vai ficar boa?

Cf: Vai.

R: Mais alguma coisa?

Cf: Não.

R: Prancha 14. O que você vê aqui?

Cf: O Marcos na janela.

R: O Marcos, é isso?

Cf: É.

R: O que ta...

Cf: A mãe do Marcos ta dormindo e ele ta na janela.

R: Ela ta dormindo... e como ela ta se sentindo,?; como ela ta de saúde?

Cf: Ta um pouco mal.

R: Ele veio..., ela ficou em casa?; ficou no hospital?; veio do hospital?

Cf: Ela veio do hospital, ta deitada na cama e ele ta na janela.

R: Olhando ela ou olhando pra fora?

Cf: Cuidando dela.

R: Ah, cuidando dela. E o que ele está pensando nesse momento?

Cf: Ele ta pensando em trabalhar de novo.

R: Por que ele tinha parado?

Cf: Parou de trabalhar e quer trabalhar de novo.

R: Por que ele parou de trabalhar.

Cf: Porque o dinheiro que eles tem é muito pouco.

R: Mas se o dinheiro é pouco ele para de trabalhar? Não entendi. 
Cf: Não tinha parado de trabalhar, aí agora o dinheiro ta pouco e ele vai voltar a trabalhar.

R: E ele parou de trabalhar por que?

Cf: Porque a mulher dele tava doente.

R: Ele faz o que?

Cf: Ele..., trabalhava na empresa Coca-Cola.

R: E o que ele fazia na Coca-Cola?

Cf: Ele era gerente.

R: Você gosta da Coca-Cola né!!!??? (risos) Quantas vezes você já botou a Coca - Cola (risos). O que tem de tão bom na Coca-Cola?

Cf: Por que é bom.

R: Ah só a Coca - Cola é boa. E aí como vai acabar essa estória?

Cf: Aí ele volta a trabalhar só que de empregado, até ser administrador, aí ele fica trabalhando e cuidando da família dele.

R: Bom... e aqui, na prancha 16, o que você vê?

Cf: Nada... Não..., aí ele ta com a mulher dele, com a família dele reunida e eles estão comendo a ceia de Natal. Eles estão comemorando que a mãe dele melhorou, o filho dele não quer mais lutar e ele ta trabalhando e cuidando da família dele.

R: Então é um final feliz, uma ceia de Natal, todos alegres, ele está empregado.

Cf: Ta trabalhando, a mulher dele está sendo cuidada e ... (ininteligível) ta procurando emprego também.

R: E o transplante do filho, como é que ocorreu.

Cf: Não foi do filho, foi do pai, do Marcos. Ocorreu tudo bem, ele ta trabalhando normal, ele ta tomando remédio, a mãe dele também.

R: Ta jóia..., acabou..., se divertiu? 


\section{ANEXO 2}

\section{Sujeito E. (masculino)}

\section{Primeira entrevista:}

A entrevista ocorreu nas dependências do Centro de Convivência..... O jovem Em., hoje com 18 anos de idade, havia sido consultado pela Dra. Vanessa, psiquiatra da Instituição, sobre seu interesse em participar deste trabalho. Na data marcada ele compareceu, fomos apresentados, expliquei o objetivo da pesquisa e sobre o sigilo. Em. mostrou-se interessado e colaborador.

R: Eu sou o Rubens e quero conversar com você pra saber da sua história de vida, a gente fica curioso pra saber, você já viveu na rua né?

Em: Correto, eu vivi muito tempo na rua, desde pivete, criancinha mesmo, porque também não tive, não tem motivo de família mas influência de amizade mesmo fui parar na rua, não por mãe e pai, mas amizade, essas coisas, acabei indo pra rua. Aí assim a minha vida foi assim, eu mesmo comecei com 7 anos de idade, sempre morei na periferia, na favela, sempre morei na favela e tudo, tenho tios, tenho vários tios que são..., trabalham no meio do crime, do tráfico, e assim pra mim foi batata pra entrar, foi batata, foi rapidinho, que com 7 anos de idade eu, bem dizer, eu não estudava direito, eu já com 7 anos meu tio já colocava droga dentro da minha mochila e já pedia pra eu levar de uma favela pra outra e, eu ali, inocentemente sempre ia, fazia, e assim eu fui crescendo, cheguei aos 8 anos de idade acabei saindo de casa, já tava fumando cigarro, puxando fumo, com 7 anos de idade eu já tava fumando cigarro, aprendi a dar um trago aqui um trago ali, e assim sempre naquele meio de adolescentes, adolescentes hoje grandes tal, e aí eu sempre no meio de adolescentes, de gente maior, dos mais velhos, idosos mesmo que trabalhavam no tráfico, e pra mim foi fácil, não teve problema pra mim entrar, não teve uma barreira que evitasse eu entrar entendeu? Porque assim, minha mãe trabalhava, passava o dia inteiro no serviço, só chegava à noite, eu com 9 anos de idade já dormia fora de casa. Aos 8 anos mesmo eu saí de casa, saí de casa a primeira vez, eu já conhecia aqui um pouco o centro da cidade, minhas tias tinha barraca de camelô no Brás e tudo e já tinha vindo algumas vezes, com 7 anos de idade já sabia andar de ônibus, aí eu vim uma vez aqui pro Brás com uns 8 anos de idade e aí conheci um outro grupo de garotos, e achei eles um pouco diferentes, eles eram diferentes, de rua e tal, aí chegando lá...eu conheci, então pra mim foi mais uma aventura nova, fiquei um tempo, eu vi os moleques usando as coisas deles, tipo cola principalmente aqui no Brás; a primeira pessoa que eu conheci tava usando cola, e eu sempre andava com um garoto, um gordinho e tal, aí legal, depois disso, depois de um tempo, os polícia me pegaram, me levaram pro SOS, aí o SOS deu um pulinho aqui, um pulinho lá, e eu sempre mentindo e tal pra não voltar pra casa, até que conseguiram achar minha casa e eu voltei pra casa de novo, aí isso daí eu já tava com quase 9 anos de idade, aí a partir dos meus 9 anos de idade eu peguei, aí eu cheguei em casa como se fosse normal mesmo, pedi desculpa pra minha mãe, ficou todo mundo ali me acariciando, pensando que daquele jeito eu não ia voltar pra rua. Aí de repente voltou o meu tio, meu 
tio mora na mesma favela que eu, faz o tráfico lá, ele é o dono de lá né..., ele voltou, começou a ficar do meu lado de novo, no começo eu fiquei uns dois meses sem fazer nada pra ele....

R: Deixe eu interromper um pouco, dá pra você fechar aquela porta?

Em: É da escada aí, é que tem pessoa que sobe e desce....

R: Bom aí você tava contando que foi pro SOS e ficava mentindo porque não queria voltar...

Em: É eu mentia porque...., sei lá, acho que eu mentia mais por medo mesmo de eu chegar em casa e minha mãe querer me bater, fazer alguma coisa e tal, minha mãe já me bateu assim, mas eu sei q não foi por motivos muito bons, com intenções boas e tudo, nunca apanhei mesmo, apanhar de fio, de chicote, igual vários que dizem que já apanhou de certos tipos né, mas assim eu sempre tinha aquele medo assim de voltar pra casa, só que aí depois eles conseguiram achar minha casa, por causa de minhas digitais, acharam meu endereço verdadeiro, aí eu voltei pra casa, me levaram, fiquei uns 4 meses, 5 ou 6 meses em casa, aí nisso depois de 2 meses que eu estava em casa, aí meu tio já tava chegando mais perto de mim, se aproximando de novo e tal, e eu voltei a trabalhar pra ele, fazia um aviãozinho aqui, voltei pra escola, aí fiz a segunda e a terceira série, e nisso daí eu acabei repetindo a terceira série várias vezes, porque não tive condições de freqüentar a escola direito e tal..., por motivos de trabalhar com a droga, aí pra mim o ritmo da droga virou uma rotina, aos 9 aos 10, chegando aos 10 anos de idade já virou uma rotina, pra mim era normal aquilo que eu morava na periferia, todo mundo com arma aqui, arma ali, então isso pra mim era normal, aí depois com 9 anos eu voltei pra rua de novo, voltei porque eu tava usando, eu comecei..., não comecei com maconha, não comecei com farinha, eu comecei diretamente na pedra, na química mesmo, porque eu trabalhava com ela já, todo mundo usava e tal, então eu experimentei uma, duas vezes e acabei nessa experimentação ..., continuei a usar, e aí ..., depois de um tempo, eu não queria que ninguém soubesse, eu tava com 11 anos de idade mais ou menos, eu não queria que ninguém soubesse, voltei pra rua, e aí aqui na rua fiquei uns 6 meses, e nesses 6 meses que eu fiquei aqui na rua aí voltei pro Brás e conheci o pessoal do Brás tudo, aí comecei a cheirar cola com eles e tal, tava esquecendo da pedra e troquei pela cola, e fiquei cola, Thiner, lançaperfume, cheirava e tal, eu gostava da brisa, da loucura que se passava, um modo criativo assim entre aspas, um jeito diferente, gostei, aí eu curti aqui no Brás um bom tempo, aí depois disso o SOS me pegou de novo, voltei pro SOS, só que dessa vez nem me levaram pra casa porque eu escalei um cabo de aço que tinha, porque o SOS que tem aqui tinha escola atrás né, não sei se o sr. sabe, tem escola do lado, e ali tinha um cabo de aço no quarto andar...e os moleques fugia, então pulava pela janela e entrava por aquele vitrozinho assim, passava, descia o cabo de aço e caía no telhado da escola pra você pular do portão pra fora, então dessa vez aí eu fui junto com os outros moleques e fugi e tal, aí dentro do SOS eu já tinha conhecido outros moleques, não era mais os moleques do Brás, esses moleques colava na Sé, ficava na Sé, que é o modo de dizer..., aí a gente começou a colar ali na Sé, e na Sé é diferente, se você analisar na Sé, antigamente mesmo, é assim, tem duas divisões, tem o chafariz no meio, tem esse lado aqui que passa as pessoas e tem esse lado que passa pessoas, então assim eu usando droga sempre tinha uma certa brisa, um clima diferente, você via que tinha ali, porque desse lado só tinha quem usava pedra, o crack, só tinha quem usava o crack e desse lado só tinha quem usava cola, cheirava Thiner, e dali nunca se misturavam um com o outro, quando se misturava tinha que trocar de droga..... 


\section{R: Era um território....}

Em: É, cada um tinha um território, sua parte, sua área né, aí nessa época eu fiquei um bom tempo na Sé, conheci o pessoal e tal, aí eu voltei a usar pedra, o crack de novo, aí isso foi virando rotina, e aí pra eu poder ta usando, eu tava com dinheiro no começo e tal, já tava andando junto com os moleques que tava roubando, fazia um bolso aqui, puxava um celular ali, aí nisso daí eu tava sustentando o vício do modo deles, roubando, pedindo, sustentando o meu vício que era a droga..., aí depois de um tempo eu passei a conhecer o Pátio do Colégio que é do lado, porque ali nós usando a gente sempre ficava ali, nunca saía dali, saia só pra dar uma volta ali, comer um lanche, fazer um roubo ou pedir um dinheiro do lado, voltava sempre pro mesmo lugar pra usar a droga lá, aí depois disso conheci o pátio do colégio também, e aí comecei a andar na Sé e no Pátio do Colégio, aí do Pátio do Colégio, tava com uns 11 anos mais ou menos, conheci uma garota lá que era traficante, vou dizer só o apelido dela mesmo que era Neném, aí tinha a Neném e o Chupeta, ele era o marido dela, aí conheci ela e tal, eu tava sempre junto com ela sempre ali e tal, tinha uns prédio abandonado, a gente ficava lá encima dos prédios, conheci o pessoal, aí eu deixei a Sé de lado, aquele lado começou a ficar sendo meu território, fui me adaptando em cada lugar, entendeu, e ali a gente começou a usar drogas, pedra toda hora, ela fazia o tráfico, ela tinha sempre, aí ela me chamou, comecei trabalhar pra ela, depois ela se separou do marido dela e tal, aí mataram ele, aí depois de um tempo, depois de uns 6 meses mais ou menos, eu fiquei nessas duas rotinas, nesses dois lugar, depois desses 6 meses eu fui pego pela polícia aí me levaram pra delegacia, pra um DP que tem aqui na Luz, aí fui pego roubando e tal, aí eles me deram a chance de voltar pra casa, eu dei o endereço e me levaram em casa de novo, dessa vez eu fui com a polícia, imagina a vergonha, aí cheguei na porta de casa e tal, falaram com minha mãe..., nisso daí eu fiquei em casa, eu fiquei quase um ano em casa, dos 11 pros 12 anos, até mais ou menos metade dos doze anos, eu fiquei em casa e voltei a mesma rotina com meu tio, a traficar com ele e tal, e não tava usando pedra, eu tava andando com ele, curtindo e usando cocaína, bebendo nos bar, traficando com ele, comprando minhas roupa, isso sem minha mãe saber, até tinha as desconfiança dela, mas ela não sabia ainda, e nisso daí a gente foi indo direto, dos meus 12 anos fui curtindo com meu tio...

\section{R: Quantos anos você tem agora?}

Em: Hoje eu tenho 18 anos.., aí fui curtindo com meu tio dos 12 pros 13 anos, então eu traficava pra ele, pegava um dinheiro aqui, e sempre tinha uma bronca pra cobrar dele, uma bronca que ele queria que cobrasse, e eu como era o sobrinho dele eu tinha de ser o maioral lá na favela, aí quando eu tava com 12 anos ele me deu uma arma, um buldoguinho, pequenininho, um 38 pequeno, buldogue, ele me deu a arma, deu pra mim de presente: - Pô legal. Achei a maior maravilha, primeiro presente que eu ganhei e tal, aí pra mim depois que eu peguei essa arma eu me senti o tal, ele pedia pra eu cobrar um dinheiro de um nóia, de um usuário, eu ia lá já chegava colocando o revólver na cara dele e tal, falava que tinha 2 horas pra arrumar o dinheiro e sempre botando medo em todo mundo né, então todo mundo tinha medo de mim, o pessoal da escola, aí voltei a estudar também, aí o pessoal da escola tinha medo de mim, o diretor e tudo, e a gente sempre ficou ali e tal, naquela rotina, depois disso quando eu voltei pra rua de novo, já tava com uns 13 anos, voltei aqui pro Brás, aí fiquei com os moleques né, eu retornei aos primeiros garotos que eu tinha encontrado aqui na rua, eles já estavam usando pedra, outros continuavam usando cola, ou tavam usando as duas coisas, aí eu comecei, continuei usando as duas coisas e 
tal, e a gente tava na estação do trem, do Brás aqui, aí tava puxando boné ali, e tal puxando boné da cabeça dos outros....

R: Como é isso?

Em: É puxar..., bombeta.., boné, pegando boné da cabeça dos outros.

R: Não faço idéia...

Em: Não, a pessoa ta dentro do trem, ta sentado do lado da janela, a gente chegava...

R: Isso por brincadeira?

Em: Não..., pra roubar mesmo....

R: Ah roubar o boné...

Em: Ah! isso daí era uma diversão pra nós, roubar o boné das outras pessoas, aí a gente chegava na porta do trem, esperava quando tivesse fechando, esperava quando o trem começa-se a andar, a pessoa tava com a cabeça do lado de fora da janela com o boné a gente metia a mão no bico, puxava e vinha embora, aí a gente saía pra fora, cada um pegava um monte de boné e tal, aí vendia pros camelôs, às vezes jogava fora, pegava uns pra nós,a gente sempre ficava nessa rotina, aí comecei a pegar o trem de um lado pro outro com os moleques, aí nós começamos surfar encima do trem e tal, eu adorava ficar na porta do trem sentindo o vento ali bater na cara, aí teve uma vez que a gente tava vindo de..., eu não sei o nome daquela estação pra lá..., depois da Luz, lá pra baixo, aí a gente foi pra lá da Luz e tal, daí quando a gente tava voltando, a gente tava encima do trem, aí tava o segurança só esperando pra pegar a gente né, aí cada um com um saquinho de cola na mão, todo mundo na nóia, na loucura ali, o trem andando, tava indo devagar, nós pulamos encima do telhado, o telhado quebrou e tal, aí eu bati a cabeça, cortei a cabeça, tem uma platina na cabeça, tem um pino aqui, aí disso daí eu caí, fiquei no chão e tal, aí fui acordar depois de 2 semanas de coma no hospital, cheio de ponto na cabeça no queixo, acho q eu caí de cabeça nas pedras...

R: E você tava me dizendo que o pessoal tinha medo de você, e como é q você se sentia com isso?

Em: Ah sei lá.., eu me vangloriava assim, eu achava que era o bom, eu gostava assim, porque pra mim era uma esperteza, eu tinha a menina que eu queria, eu podia zoar com quem eu queria, porque eu sabia que ninguém ia mexer comigo, ninguém ia vir por cima de mim e se viesse eu tinha como reagir, então eu não me garantia em mim, eu me garantia no que eu tinha, nos meus amigos que eu tinha, me garantia no meu tio, achava que ele ia me salvar de qualquer coisa que ia acontecer comigo, então pra mim eu era o maioral ali, eu podia zoar com qualquer um que ninguém ia me pegar, e ninguém me pegava mesmo por que todo mundo sabia que eu tinha o apoio do meu tio, tinha o apoio de todo mundo....

\section{R: E você precisou alguma vez do seu tio?}

Em: ......Nunca precisei do meu tio assim basicamente, nunca precisei do meu tio, somente assim... às vezes em questão de drogas e... dinheiro, que isso daí eu pegava com ele aqui e pagava ali, eu pegava um dinheiro com ele aqui, chega lá e ia trabalhar pra ele, trabalhava um dia, metade de um dia e pagava pra ele, ...eu nunca precisei dele, eu tinha minha confiança em mim mesmo, mas também tinha confiança nele, que eu também acreditava nele, nunca precisei porque nunca tretei com ninguém, ...nunca cheguei a bater em ninguém, eu cheguei a dar um tiro num rapaz, isso daí com quase 15 anos de 
idade, nós estava fazendo um roubo lá onde que eu moro mesmo, roubando um ônibus, aí nós saímos do ônibus, tava eu e um outro rapaz e um amigo meu, aí quando nós saímos do ônibus ele começou querer dar uma de zóião no dinheiro né, então eu vi ele guardando dinheiro a mais no bolso do que nós tinha pegado, aí o mano que tava com nós, o L., pegou e viu o dinheiro, que ele tava guardando dinheiro, então nessa daí eu peguei e cheguei nele: - E aí meu, qual que é? Você ta dando uma de zóião...., ah não vai?.....vai logo dá um tiro nele aí..., peguei o berro, o 38 na minha mão: - Eu não, não peguei, não peguei.....Eu peguei e tirei o dinheiro que tava no saco dele, ele colocou o dinheiro no saco e tal e falei: - Ah é..., agora corre!!!! Mandei ele correr e dei dois tiros nas pernas dele, então é a questão, eu confiava no meu tio, não pude confiar né, que meu tio parece que não ligou pra isso daí e então tive que sair de casa, aí eu peguei e saí de casa.....

\section{R: Por que? Queriam vingança?}

Em: Não, ele não quis se vingar entendeu? Mas eu também..., eu fiquei com medo, fiquei com medo dele se vingar porque eu não confiei em mim mesmo...., eu tinha com o que reagir se ele viesse se vingar, mas eu tinha um medo também, um medo que me deixou...,

aí eu peguei e fugi pra rua...

R: Mas você esperava que seu tio fizesse alguma coisa..

Em: É eu esperava que meu tio fizesse alguma coisa e ele não fez. só que aí passou um tempo, eu voltei, mas também teve as vezes que eu fui preso, que foi antes, que foi aqui na Sé mesmo, fui preso uma vez, fui pra UAI (Unidade de Atendimento Inicial) ali, e essa história do tiro ta no meio, quando eu fui preso a primeira vez eu falei que não tinha família e tal, minha família morreu, eles com certeza não acreditaram mas... como eu era primário né aí eu fiquei um mês lá na UAI, depois peguei e saí eles me trouxeram pro SOS Criança, daí fui pra rua, aí fui preso a segunda vez, fiquei um mês e pouco, fui pra Febem, ali na UAl depois fui lá pro 7, aí depois saí, quer dizer me mandaram pra semiliberdade né, aí foi nessa época aí que aconteceu, depois de tanto roubo de tantas coisas me mandaram pra uma semi-liberdade e dentro da semi-liberdade ta todo mundo ali que é do crime e tal, curte um rolê, aí na UE (Unidade Educacional) tinha uma semi-liberdade aí eu fui pra lá e fiquei acho que uns 4 dias só, aí liberaram a gente pra sair pra rua, que lá você sai de dia e vem pra dormir a noite, se você estuda, eles arrumam estudo e serviço pra você essas coisas, então no quarto dia me soltaram pra rua, então já me juntei com os moleques de lá de dentro de 4 dias já conheci todo mundo conversei e tal aí quando eu saí pra rua já fumei um baseado com os caras, aí firmeza, aí cheguei e fui numa favela vizinha que tinha lá, conheci o dono da biqueira (ponto de venda de drogas), o pessoal conhecia muita gente lá de onde que eu moro em Santo Eduardo, aí o pessoal conhecia muita gente lá, conhecia meu tio, então peguei uma coleta ali também, aí eu não voltei pra UE pra semi-liberdade, eu não voltei, então fiquei de busca e apreensão, aí fiquei lá na favela e tal, aí fiquei num barraco dum cara lá e tal, fiquei uma semana vendendo pros cara lá, trabalhando pro cara, o cara confiou em mim e tal, aí peguei na fissura de usar os negócio mesmo, tava louco, ele me deu uma quantidade de droga, não lembro o total mesmo, faz tempo, aí eu peguei e saí, usei a droga dele e fui embora, então quer dizer eu fui embora e voltei pra casa, depois que eu voltei pra casa e tal eu voltei pra mesma rotina com meu tio e aí aconteceu esse negócio aí do crime que nós fez que eu dei o tiro no rapaz aí depois disso depois que eu dei o tiro nele eu peguei e tal, fugi voltei pra cá, fui pra casa de minha tia, fiquei um tempo escondido na casa da minha tia e eu tava de busca e 
apreensão também, aí foi mandado de busca e apreensão na minha casa, foi parar polícia na casa da minha tia também, aí na casa da minha tia foi um outro processo, tava com uns 15 anos de idade, na casa da minha tia eu já conhecia o pessoal lá, então conforme eu conhecia o pessoal que trabalhava com a droga, porque a única amizade que eu tenho, que eu tive mesmo é só quem trabalhava com droga, quem era usuário, então eu fui conhecendo o pessoal e lá o pessoal não é da baixa assim, não é pessoal de favela, de periferia, lá é gente playboyzinho, gente que tem dinheiro, então me juntei com eles e comecei a ficar lá, usar droga com eles e tal, curtir os meus baratos, aí tinha uma casa lá e dentro dessa casa tinha um rapaz que vendia as drogas dentro da casa, por isso que não tinha muita polícia, não tinha muito movimento na rua mas à noite tinha o maior tráfico, então comecei a comprar os meus negócios, minha tia ficou desconfiada também, entendeu? Minha tia já ficou desconfiada de eu chegar tarde em casa, chegando daquele jeito, ela sabia que eu usava, nessa época minha mãe já sabia também que eu usava, aí fiquei assim comecei a ser discriminado, já pela minha família toda que não curtia o negócio, então todo mundo me discriminou e eu tava sem chance, ninguém tava dando chance pra mim, pra eu poder me regenerar e tal, então me afundei mesmo, fui pra droga, aí comecei a roubar lá, aí me juntei com uma garota lá, fiquei um tempo e tudo..., aí eu fiquei com a mina, a gente teve um caso e tal, a mina engravidou, depois que ela engravidou a avó pegou a filha, a menina, eu não sei, eu sei que eu tenho a filha né, que é minha mesmo porque a mina era firmeza e tal, mas eu só vi ela depois que nasceu, até um ano de idade mais ou menos eu vi ela, depois disso a avó dela tomou da neta porque ela usava droga, a gente usava junto e eu tava morando na casa dela e tal, aí eu sai da casa dela e voltei pra casa da minha tia, ela me aceitou de novo né, e depois disso eu nunca mais vi a garota, não vi minha filha, tenho saudade até hoje, nem sei....., nem sei o nome dela, nem lembro de nada também porque..., pra mim eu tenho certeza que a droga afetou muito a minha mente, depois daquela do trem também direto eu tô tomando remédio..., tudo isso num círculo vicioso, tudo por causa da droga, tudo por esse motivo, aí com 15 anos eu voltei pra casa da minha tia, já tava pra fazer 16 anos, a polícia tava atrás de mim, e eu não tive alternativa, eu mesmo falei pra minha tia, - Ô tia eu quero ir pra uma clínica. Ai ela: - Legal ..., vou ver pra você aí. Procurou uma clínica lá perto, em Mauá, legal pra caramba, eu fui, fiquei ali no Projeto Jovem, eu fui pro Projeto Jovem fazer a ficha, ver como é que era e tal, só que aí quando eu falei que tinha passagem pela polícia e eles puxaram lá e tava busca e apreensão, então falaram pra mim: - Você tem de falar com o juiz, tem de ver com o juiz se ele libera você vir pra casa de recuperação e tal, essas coisas. Então fui pro juiz, minha mãe foi pro juiz comigo, eu fiquei com medo de ser preso de novo, ai nós chegamos lá e tal, eu conhecia um projeto o Quixote, eu conheci a um bom tempo atrás quando eu era pivete, eles tratam de adolescentes químicos essas coisas, aí assim eu conhecia o Projeto Quixote e tinha o advogado de lá, e esse advogado me ajudou quando eu fui no Fórum pra pedir pro juiz me dar, pra poder ficar na casa de recuperação, então chegando lá eu peguei, eu falei com ele minha mãe falou com ele, ele falou: -'Legal'; ai foi lá com a gente no Fórum, me apresentei e falei que queria ir pra casa de recuperação, que eu sei que tava de busca e apreensão e tal, e o juiz queria me segurar lá e queria me mandar de volta pra semiliberdade, só que ai o juiz falou: - Não o cara ta querendo parar e tal, você pode mandar pra casa de recuperação? Ele falou nesse modo de advogado com juiz, do jeito dele, que eu tava precisando e tal por causa de motivo de droga, então o juiz me liberou pra ir pra casa de recuperação, aí determinou o tempo certo da casa de recuperação que é 9 meses, aí eu fui, fiquei 10 meses na casa de recuperação evangélica e tal, rígida também, não tão rígida, a gente não tinha piscina, igual muitas casas de recuperação eu vejo que tem e os adolescentes 
não voltam legal por causa disso, eu acho que isso daí também não pode ter, em casa de recuperação não pode ter piscina por que eu acho que não ajuda muito, tem que ter lazer mas não essas coisas de piscina, liberar pra fumar porque fumar eu também acho que é uma química, eu fumo tudo bem, mas fumar eu acho que é uma química, trás muita ansiedade de usar alguma coisa, entendeu? Aí fiquei lá, tinha instrução religiosa, tinha castigo, tinha tudo lá, tinha várias coisas que a gente ia fazendo, tinha terapia ocupacional, tinha lava isso lava aquilo, aí a gente sempre se ocupava em alguma coisa, e assim eu fui apreendendo, assim eu perdi a vontade de usar droga, eu tenho, eu sempre tenho vontade, esse final de semana que passou eu fiquei bem dizer trancado dentro de casa, tava na maior fissura pra sair, não vou falar que é pra usar droga mas eu ia usar droga com certeza se eu sair, que eu tava com vontade de sair e curtir com os cara que usa droga, entendeu? Pra curtir salão com os cara que usa droga, então pra mim não ia ter vantagem nenhuma, bem dizer eu fiquei trancado em casa porque tava na fissura de usar um negócio, ai assim eu fiquei mais que o tempo na casa de recuperação, eu fiquei 10 meses, aí depois voltei pra casa e chegou um mandato de busca e apreensão de novo pra mim, porque era pra mim ter voltado pra casa de recuperação quando eu saísse da clínica, aí eu falei com meu advogado e tal, que o advogado lá porque, porque eu não podia voltar pra semi-liberdade, porque se eu voltasse eu ia voltar a usar, porque ali todo mundo usa, tem droga lá dentro mesmo da semi-liberdade, eu conheço, tem droga, lá dentro tem tudo, o pessoal, eu conheço todo mundo, que ia adiantar pra mim? Ia ser uma batalha a mais pra mim, ia ser muita tentação se me mandassem de volta. Então eu falei com meu advogado e tal, ele foi lá conversou com o juiz, pediu uma L.A. (Liberdade Assistida), e tal pra eu ficar casa, aí legal o juiz me deu a LA aqui no Belém, eu vim pro Belém, fiquei ai, e a Cecília minha assistente me dá maior apoio, maior força hoje, e nisso daí eu me internei com 16 anos sai com 17, então foi legal pra caramba porque eu já to há quase 3 anos sem usar nada, 3 anos não..., é quase 3 anos.

R: Está quase terminando a fita, a gente podia ir tomar um café e voltar depois...

Em: Vamos na padaria....

R: Então enquanto a gente tomava café você tava me contando que o que fez você parar com essa vida, conta de novo.....

Em: O que me fez mesmo..., deu vontade de eu ir pra casa de recuperação não foi nem tanto droga nem o crime, pra mim foi mais a questão que eu tava sentindo falta da família ali, eu tava percebendo que eu tava me afastando da minha família, eu já tinha ido pra casa da minha tia depois que aconteceu aquele rolo, e acabei saindo da casa da minha tia não porque eu queria bem dizer, eu fui meio que empurrado, não um 'vai embora', mas meio que empurrado, aí fiquei com aquela garota e tal, então voltei pra casa da minha tia e aí eu vi que eu tava me afastando da minha mãe, das minhas tias, meus tios, tenho vários tios ali, tem em Mauá, em Santo André e tal, então eu percebi ali que eu tava me afastando, então ...e ali eu vi que o ponto que eu tava me afastando mesmo era a droga, que se eu não trabalhasse com a droga e com o que eu tava fazendo do crime eu não ia ter minha família de volta eu não ia ter a confiança dela, e aí eu tive que optar ir pra casa de recuperação e nessa questão o pessoal me deu um apoio meio que 'ele vai mas não vai se recuperar', e isso daí quando eu sai da casa de recuperação aconteceu, então pra mim eu senti que tava faltando a minha família, que eu não tava mais com ela, que eu não tava mais com ela entendeu.... 
R: Da tua família tem o teu tio que te pôs no crime, agora fala dos outros, do resto da família..

Em: Então o resto da família assim entendeu, antes de saber que eu usava droga, que eu tava..., eu disfarçava....

R: O único tio que tava no crime era esse só ou tinha outros?

Em: Não tinha outros tios meus que estavam no crime, tinha um outro rapaz que é meu tio também e tava no crime, ele tava no crime assim entre aspas, porque ele usava drogas, porque ele é um dos que usava cocaína entendeu?; é trabalhador tudo, tem a mulher, tem a filha, tinha a casa dele, ele trabalha e tudo, mas é um cara que também usa droga entendeu? Usa cocaína, ele gosta de chegar no final, sexta, sábado e domingo, até meio de semana, cola no bar, ele tem 10 reais o outro tem 10 reais e tal, então pega uma farinha, vai buscar uma farinha pra nós e tal, e então assim e ai a gente fazia aquela rotina e tal, e quando um tinha o dinheiro mandava buscar, quando o outro tinha mandava buscar, e quando todo mundo tinha, todo mundo mandava buscar entendeu? E a gente sempre usava, tinha esse tio meu, tinha uns primos meus também, que usavam bastante, tem um que até hoje usa pedra....

R: Agora da família, quem é que você sentia mais falta, que você pensava, o que doía mais?

Em: As pessoas que doíam mais era os meus irmãos, entendeu? Que eu tenho 8 irmãos, 9 comigo, e assim meus irmãos bem dizer, do jeito que eu comecei com 7 anos eu não parava em casa, então agora que eu tô fora da droga tem 2 anos e pouco vai fazer 3 anos que eu to conhecendo meus irmãos, eu não conheço os meus irmãos, não vou falar que conheço porque não conheço, que eu não convivia com eles, eu não ficava em casa eu ficava na rua, vinha pro Centro da cidade, ou ficava na Biqueira na favela, e assim é meu!; eu não conheci meus irmãos, é uma coisa que eu sentia muita falta, que doía mesmo, que as vezes mesmo quando eu usava um negócio, droga assim, tinha vez que eu parava pra pensar, entendeu...

R: Então até os 7 anos como foi sua relação com eles....

Em: Até os 7 anos eu não lembro dos 7 pra baixo, eu não lembro porque aí vem $6,5,4,3,2,1$..

R: Mas você tinha saudades? Porque tinha uma coisa que você nem lembrava direito.... não era mais uma fantasia....

Em: Eu via os meus irmãos direto e reto, eu via sempre os meus irmãos, igual a muitas pessoas de lá do meu bairro que eu via, brincava com meus irmãos ali, meus irmãos é tudo mais novo que eu, quer dizer brincar com meu irmão ali, bater uma bola, jogar uma ......., rodar peão, bolinha de gude, isso aí eu nunca fiz, empinar uma pipa com meu irmão, nunca fiz, minha rotina era chegar na favela, entrar em casa não falava com ninguém, porque eu chegava drogado, não falava com ninguém, chegava em casa, tomava um banho e caia na cama, no outro dia era só acordar tomar um café e ia pra rua, só voltava à noite do outro dia, de madrugada ou no meio da tarde....

R: E como você descreve a relação com o pessoal da rua?

Em: Eu achava que o pessoal da rua, eu achava assim, pra mim era irmão, porque ali na rua é um clima de gangue, entendeu? De um grupo, de um pessoal que é uma gangue, é um pessoal ali grande, cheio de moleques mesmo, por que ali a gente andava só em 3, 4, 5, até 8 moleques entendeu, andava junto no meio da rua, uns sujos, outro de bermuda, com cobertor nas costas, eu andei 
varias vezes com o cobertor nas costas, eu sempre andava ali entendeu? E ali quando um tinha uma coisa na rua, quando um tinha uma coisa, pode ser um pedaço de pão, pode ser qualquer coisa, sempre divide ali com os outros, não só o pão, a comida, mas como a droga, tudo entendeu? A gente andava junto, a gente se chamava de irmãozinho....

R: Tinha uma união...

Em: Tinha uma união..., então pra mim os meus irmãos era aqueles que andava na rua, meus irmãos de casa eu não conheço, meus irmãos de casa não andam comigo...

Neste momento o gravador parou por causa da pilha, quando percebemos religamos, mas perdeu-se um pequeno trecho da entrevista.

Em: ....eu tinha também que é pai de rua, mãe de rua, igual eu falei da N. e tal, ela pra mim era como uma mãe entendeu? eu vendia droga pra ela e tudo, mas a hora que eu queria parar de vender então ela: - Então sobe lá pra cima, vai descansar um pouco...., então eu subia lá pro prédio, lá pro quarto e ficava lá, deixava meu cachimbo de lado, recheava de pedra ali e começava a queimar, pra mim ela era uma mãe também, porque ela cuidava de mim, ela não deixava eu usar uma droga sem comer, se eu não comesse alguma coisa antes ela não deixava eu usar entendeu? Ou depois que eu usasse e ela visse que eu tava ruim ela me dava um copo de leite, ela ia comprava um litro de leite e me dava um copo pra mim melhorar, então era pessoa que cuidava demais, era pessoa da gente, era pessoa igual a gente, ela também tem consciência que tem o mesmo vício que nós, que tava do mesmo jeito.

\section{R: E você não ficava triste?}

Em: Tinha vez que eu ficava triste sim, só que aí eu procurava esconder mais a tristeza atrás de droga, ou então ia lá e roubava um dinheiro, pegava uma prostituta e ia pra um hotel, ali na..., teve uma parte que eu até não falei pra você, ali na Guaianazes, ali na Crackolandia, aí tem uns hotel que é meio pra baixo mas aí a gente tira umas menininhas e : -Tó 10 real, vamos subir lá pra cima. Ia lá pro hotel, fazia o que tinha que fazer, então pra mim era normal, era o jeito que eu tinha de esconder aí quando eu tava triste, eu cheguei a chorar já num canto, quando eu tava sem droga, ficava pensando pra caramba, dava uma saudade de casa, tinha vez que eu ficava com saudade de minha mãe, eu chegava lá embaixo do viaduto, ficava lá, ali na Sé, ali perto da Sé tinha aquelas escadas ali, vamos supor, nosso mocó, é o apelido dele, ali debaixo do viaduto tem um pedaço quebrado, ai eu ficava ali......

R: Quando sentia saudade da tua mãe, o que você lembrava, o que te fazia falta, o que você pensava?

Em: O que me fazia falta era minha mãe do meu lado, minha mãe ela sempre esteve do meu lado, mas não do meu lado totalmente, porque ela nunca chegou pra conversar comigo, pra saber o que tava acontecendo, pra saber porque eu to triste, a minha mãe o trabalho dela..., era trabalhar era só isso trabalhar, colocar as coisa dentro de casa e o resto vocês que se virem, entendeu? Hoje ela tem medo de morrer, ta com idade e, eu falo pra minha mãe: - Ó mãe eu não quero esses moleques empinando pipa, ficar empinando pipa no meio dos moleques, por ali é no meio da favela e, ali eles ficam no meio dos marmanjão, ela não imagina ali como era antigamente, como eu conheci, então eu sempre falo pra ela: - Ó mãe a senhora nunca percebeu mas eu comecei assim, tem vez que eu 
falo pra ela, porque a minha mãe nunca chegou pra mim e me encostou num canto da parede e falou: Pô meu o que ta acontecendo com você? Você ta precisando de alguma coisa? Nunca chegou pra falar nada, nunca chegou pra sentar comigo, nunca me deu chance pra conversar com ela, nunca deu chance de repartir minhas alegrias e minhas tristezas com ela e tal, então eu repartia com os outros......

R: Quando você começou a falar do que você lembrava dela, você lembrava o que?

Em: Quando eu lembrava dela..., eu não tinha muito o que lembrar não, eu lembrava mais quando ela tava junto com nóis assistindo a TV e tal, no sofá e tal, e fazia uma pipoca, eu tinha saudade, disso daí eu tinha saudade, aí quando eu parava pra pensar eu olhava assim...., ai ficava só pensando, aí chorava e tal, mas pra mim..., mas depois eu chegava em casa, conhecia uma pessoa no ponto de ônibus e pedia dinheiro pra voltar pra casa e aí eu voltava pra casa, eu fiz isso várias vez, isso era rotina pra mim, eu voltar pra casa e minha mãe me aceitar, minha mãe sempre aceitava, ela aceitava mas depois não olhava na minha cara, por isso que eu falo assim, sentia falta da minha família, porque todo mundo me aceitava, aí me aceitava mas sem olhar na minha cara, todo mundo indiferente assim, então eu falava 'assim não dá, eu vou embora'.....

Aqui a fita apresentou um problema e foi cortada uma parte da entrevista.

R: Então você estava falando que teve uma época na rua que você não tinha medo de morrer e que agora mudou.

Em: Não tinha..., pra mim eu não tinha sentimentos, eu não tinha motivos pra ter sentimentos, sei lá pra mim não tinha importância porque eu não pensava em mãe, não pensava em pai, meu pai mesmo nunca tive pai, não queria saber.....

R: Me fala do seu pai....

Em: Eu nasci em Garanhuns, em Pernambuco, com 3 anos de idade eu vim de lá entendeu? Aí tinha só eu e minha irmã, era só eu, minha irmã e meu irmão e acho que uma outra irmã minha, eu tinha uns 4 anos de idade, por aí, então eu vim de lá com 4 anos de idade, do jeito que se ta agora você não lembra do seu pai, até os 12 anos você não lembra de seu pai, eu não conheci meu pai, meus irmãos não conhecem meu pai, entendeu, que é o mesmo que o pai deles que é o mesmo....

R: Não mas você veio de Garanhuns com 3 anos de idade, o seu pai não morou lá com você?

Em: Ele morava com a minha mãe, aí minha mãe separou dele e veio embora pra SP.

R: Mas você morava junto.

Em: Eu não lembro.

R: Você não lembra mas você conheceu.

Em: Eu conheci mas eu não lembro, eu pareço com meu pai mesmo porque agora com 15 anos de idade, eu fui visitar meu pai, com uns 14 anos de idade, então essa parte aí eu nem falei, minha mãe me mandou pra lá por causa de droga, foi até bom eu ir lá, minha mãe me mandou pra lá pra casa do meu tio, 
entendeu? Chegando lá nessa época eu tava viciado em droga, tava mesmo, tava locão e tal, nisso daí eu levei 3 papel de pedra daqui pra lá, então eu cheguei lá usei, não tinha mais como usar, não conhecia ninguém que usava, aí conheci meu pai, mesmo assim fui falar com meu pai depois de 3 semanas, eu falava que ia matar ele, sempre falei que ia matar meu pai porque...., não tinha motivo mas sempre falei, 'eu vou matar meu pai, quando eu ver ele eu vou matar ele, ele nunca vai escapar de mim', eu tinha sangue frio, eu falava...

R: Você não tinha motivo real, mas você tinha motivo na sua cabeça....

Em: É eu tinha motivo na minha cabeça, minha mãe nunca falou dele aqui, e eu também não me preocupei em perguntar pra ela, só que assim eu pensava: "Meu pai não me criou, porque então?". Minha mãe não dava chance de eu falar e ela não falava também porque eles se separaram e tal..., aí eu fiquei umas 3 semanas sem falar com ele e tal, com minha droga, em 3 dias eu usei a minha droga, quando eu cheguei lá fiquei na casa do meu tio, ninguém percebeu, aí depois de 3 semanas eu conheci meu pai, aí falei com ele, aí comecei a freqüentar a casa dele e vi que não era tudo aquilo que eu tava pensando, que era um cara que bebia muito, meus tios falava que ele bebia, que bebia muito, só que quando eu fui pra lá ele não bebia, eu já era adolescente, já grandão, aí conheci as enteadas dele, filhas da mulher dele, namorei com a filha da mulher dele e tal, então não foi tudo aquilo que eu pensei, então eu não tive mais vontade de pegar ele, eu tinha fé que eu ia matar ele, mas aí depois não deu vontade..., eu lá mesmo comecei a trabalhar numa mecânica, numa oficina, aprendi bastante coisa lá e com o dinheiro que eu recebia eu dava um pedaço pro meu tio e o resto eu usava pra comprar roupa pra mim, meus baratos, conheci as mina de lá, porque dizem que quando o cara paulistinha vai pra lá, conhece todo mundo, pega uma aqui, uma lá, isso daí aconteceu, pegava uma aqui, uma lá, só que nisso daí eu conheci uma prima minha que morava lá entendeu? E ai eu fiquei 2 meses com minha prima, namorei escondido e tal, depois a mãe dela ficou sabendo e não deixou e tal, aí ficou legal só que eu ainda tinha vontade de usar droga, sempre lembrava, sempre corria atrás, aí comecei a freqüentar o centro lá, que é o comércio, aí fui conhecendo o pessoal, fui observando onde que era os bar, esses lugar, aí fui no baile duas vezes, nessas 2 vez que eu fui, conheci um rapaz lá que usava uns negócio, usava pedra, e aí já tava com uns 4 meses que eu tava lá, tava trabalhando e tudo, aí legal eu usei a primeira vez com o cara, ninguém desconfiou, ninguém ficou sabendo, que lá é um pedacinho pequeno, eu sabia que todo mundo ia ficar sabendo rápido, aí usei a segunda vez e o meu tio tava reparando que o dinheiro tava sumindo, entendeu? Que eu tava dando dinheiro pra ele ainda, mas só que o meu tava sumindo, eu não tava comprando mais roupa pra mim, num tava comprando meu sabonete, minha pasta, aí depois eu sai da oficina, com 5 meses eu sai da oficina e fui trabalhar no desmanche de carro, em frente esse desmanche de carro tinha dois moleques lá também que trabalhava lá, usava uma droga e tal, aí conheci os moleque, aí os moleque começou fazer..., começou trocar idéia, aí comecei falar como é que era aqui em SP e tal, quem eu era aqui em SP, aí legal né meu, aí os moleque cresceu os olhos em mim também, o gordão já usava uma droga, uma cocaína legal: - Aí..., vamos pro salão então, tem um salãozinho aqui perto, é um tal de ..., nem gosto de forró entendeu, aí nós fomos, aí no mesmo dia que nós foi ele apresentou um papel de farinha e eu falei : - Pô, maior cara (tempo) que eu não uso. Aí peguei e deixei um dinheiro com ele, depois que eu deixei esse dinheiro com ele eu não levei mais dinheiro pro meu pai, não dei mais dinheiro pro meu tio, e ai todo mundo percebeu e ai eu fiquei 8 meses, conheci uns moleques, andei com os moleques, não tive problema com ninguém entendeu? Aí fiquei com as garotas de lá e tudo, não tive problema, nada, mas não adiantou eu continuei usando a 
droga, conheci o moleque e continuei usando lá, não adiantou minha mãe me mandar pra lá porque, a questão não é que eu não queria, entendeu? Eu procurei, eu tava com vontade, eu tava com saudade daquele clima lá, daquele lugar, daquele jeito que é entendeu? daqui de SP, então procurei preencher aquele vazio que tava ali.....

\section{R: E a relação com teu pai não foi muito pra frente....}

Em: É não me aproximei dele, continuei morando na casa do meu tio, não tinha nada a ver, falava assim com ele dificilmente, ia só na casa dele pra ficar com a enteada dele, não tinha nada a ver, conheci a mulher dele, super gente fina, eu me dei bem com o pessoal lá, entendeu?; só não me dei bem porque eu comecei a usar droga de novo, então a droga prejudicou tudo, ai meu tio pegou, fiquei 8 meses lá e meu tio me mandou pra casa de volta...

\section{R: Isso você tinha 16 ?}

Em: Eu tava com uns 15 já, aí eu voltei pra cá fiquei aqui de novo, aí aconteceu tudo que eu já falei...

R: Você acha que teve uma coisa que marcou assim, um fato, é claro que teve um conjunto de coisas que foram marcando até você pensar eu não quero mais essa vida, mas não teve um fato assim que detonou, que foi mais importante?

Em: O fato que marcou bastante foi a garota que eu fiquei, a questão da minha filha também, acabei não conhecendo ela, deve ta com uns 3 ou 4 anos, não conheci ela, nem corri atrás mais, e outro fato também que foi uma garota que eu gostei bastante, evangélica essa mina, morava lá perto de casa, várias vezes me chamou pra ir pra igreja com ela...., ela estudou comigo entendeu, ela sabia que eu usava, mas ela sempre quis me tirar, ela gostava de mim, a gente já se beijou e tal, mas sempre naquela que o pai dela, a mãe dela era evangélica e o pai dela empresário, quer dizer, ela é rica eu sou pobre, morava no maior casão na rua de cima que eu morava, eu morava na favela ela morava na rua de cima, então por isso que não dava certo, eu gostava dela, uma mina que até hoje bem dizer...., eu amei essa menina, entendeu?; e ela sempre gostou de mim, hoje em dia eu não vejo mais ela, hoje em dia acho que ela ta casada, que eu era pivete, mas assim, ela era uma pessoa que gostava de mim pra caramba, me levava pra igreja, desafiava a mãe dela e o pai dela por mim, entendeu? desafiou várias vezes....

R: E como é que você acha que ela, a existência dela na sua história influenciou pra você mudar...

Em: Eu acho assim, ela que me levou bastante a conhecer Deus, ela já chegou em casa eu tava drogado, tava no sofá uma vez, essa vez eu não vou esquecer que eu dei risada pra caramba, eu tava drogado e tal, eu tinha acabado de fumar maconha aí eu deitei no sofá, liguei a TV e dormi, entendeu?; eu dormi nem meia horinha ela chegou, ela gostava muito de mim, ela ia lá em casa, o pai dela não queria que ela fosse lá em casa, e ela ia lá no meu barraco, no meio da favela, uma garota da alta sociedade e tal, humilde, então ela ia lá em casa, acabou me acordando com um cabo de vassoura, ela viu que eu tava louco, ela quis me levar pra igreja, e ela foi uma das pessoas que conversava comigo, pra mim era uma amiga, mais pra amiga..

R: Mas ela conversava que tipo de conversa?

Em: Ela conversava assim, ela sabia o que eu tava sentindo, sempre que eu tava pra baixo, ela nunca chegava pra mim que .......????, : - E ai, como você ta e tal, você não ta drogado agora..., você não ta usando nada né? Pô fica legal, vamos pra igreja comigo. Então ela sabia falar comigo, ela sabia o que eu tava 
sentindo, ela tinha um interesse por mim, não só pela minha pessoa, por mim mesmo, não pelo o que eu era, eu tive várias mulheres, as mina gostava de mim mais porque eu era sobrinho do dono, porque eu tinha isso, porque eu tinha arma, tinha aquilo, uma pá de gente tinha medo de mim e as garotas gostava disso, ela não, ela sempre me ajudava, me tirava a droga e tal, e sempre procurando me ajudar e enfrentando o pai dela e a mãe dela, ia na minha casa dentro da favela lá, ficava com as minhas irmãs dentro de casa e, era uma coisa assim, eu tava largando a droga por ela, eu trocava várias vezes, ela ia lá em casa só pra ficar comigo, ajudando as minhas irmãs a fazer as coisas, e a gente ficava de conversinha, ficava beijando e tal, as vezes chegava os cara na porta e : - E ai loirinho, vamos fazer um rolê e tal. Eu deixava ela lá e ia fazer um rolê, bem dizer, quando eu tive a opinião de ir pra clínica, eu pensei várias coisas, pensei na minha garota, pensei na minha filha, pensei nela, pensei na minha mãe, na minha tia, eu não pensei na droga, em viver no meio de arma e do crime, eu pensei nessas pessoas que eu tava machucando, entendeu?; que eu tava perdendo, que eu tava machucando elas e tava me machucando mais ainda, então esse foi um dos motivos de eu ter a opinião de ir pra clínica, e também depois da clínica eu tive várias dificuldades, até hoje eu tenho dificuldades pra caramba, acabei levando um tiro depois que eu sai da clínica, levei até um tiro na perna e tal, mas sempre com influência por causa de que, por causa do passado, isso ai é uma coisa que todo mundo vê, eu faço a maior luta, eu não moro aqui, eu moro lá pro lado da Vila Rica, entendeu, eu venho de ônibus todo dia, enfrento a maior barra..................??????? minha família entre aspas, eles não sabem como eu me sinto, assim eles sempre me ajudam como pode e eu procuro entender o lado deles, como eles tão, eu procuro saber levar essa pessoas, saber levar minha mãe, meus irmãos, meus tios, porque meu irmão me discrimina, meu irmão que ta com 17 anos me discrimina de vez em quando....

\section{R: Só você entrou pro crime?}

Em: Só eu...

\section{R: E você é o primeiro?}

Em: Eu sou o terceiro, eu tenho um irmão mais velho, a gente era pra ser em 10 irmãos entendeu, ai meu irmão morreu quando era pequeno, aí tem minha irmã que ta com 20, ta casada e eu sou o terceiro mais velho e o resto mora tudo com minha mãe, então...a gente mora em 8 em casa, ai tem $8,9 \mathrm{com}$ minha mãe, 10 com meu padrasto, $11 \mathrm{com}$ meu tio, eu procuro bastante estar aqui, aqui no projeto, sempre estar ocupado com alguma coisa, eu não consigo ficar em casa, igual eu falei, final de semana que eu fico em casa sem fazer nada me da a maior vontade de sair, de sair com os cara pra conversar com alguém, entendeu?; aqui não, aqui eu me sinto bem, aqui eu converso com todo mundo, eu faço habilidades, eu ensino uma coisa, eu aprendo outra, então eu me ocupo, eu não tenho tempo pra parar e ficar pensando em droga, o projeto ta sendo um apoio entendeu?

\section{R: Você não procurou mais a mãe da tua filha?}

Em: Eu não procurei mais, eu procurei assim depois que eu sai da clínica, aí eu voltei pra casa da minha tia, aí procurei, eu vi ela de novo, ela tava com a mãe dela, e ela também tava desandada nas drogas, depois ela sumiu, sumiu ela, sumiu a mãe dela, só conhecia ela, não conheci a avó, não conhecia ninguém.

R: Notícia da tua filha você não tem..

Em: Não tenho, então...., eu mesmo não registrei ela, eu vivia no meio das droga e não tinha tempo nem pra mim mesmo, era muita droga.... 
R: Bom E., a fita está terminando e eu gostaria de saber se podemos continuar um outro dia?

Em: Pode sim....

R: Ok.

R: E. me fala uma coisa..., aqui da tua família alguém teve alguma doença que você se lembre?

Em: Não, só eu só...que eu tive um negócio na perna mas ninguém sabe o que que é...nem o médico não sabia, ficou umas manchas lá e era para ter amputado minha perna...

R: Pra ter o que?

Em: Pra ter tirado a minha perna, eu fiquei mais de 3 meses sem andar, com uma mancha na perna e no joelho, e aí mudava de perna, e aí uma tava uma vez uma perna boa e a outra não estava, e aí perdi a noção da perna, não sentia mais minha perna, mas de lá pra cá melhorou, os médicos falou que não pode acontecer duas vezes né, da segunda vez não passa....tem gente que aparecia com isso e eles não sabem o que é, isso eu era pequenininho, eu tinha uns 10 anos de idade...

$\mathrm{R}$ : $\mathrm{E}$ do resto dos seus irmãos nunca nenhum teve problema..., alguma doença, doença nervosa... doença séria nada....

Em: Nada...

R: E. eu vou fazer para você umas perguntas e eu queria que você me respondesse assim... bom vamos lá (passamos para a entrevista dirigida).

\section{Entrevista dirigida}

R: Qual a melhor coisa que já te aconteceu?

Em: Que eu me lembro mesmo aqui o espaço de convivência...., e a época em que eu ficava na creche...

R: Na creche...

Em: Aquela que entra com 7 anos de idade, até uns 12 eu fiquei, lá era bom, legal, mas nessa época eu já tava metido... ainda também, já tinha minhas desavenças, meus vícios e tudo, mas gostava de lá porque lá era legal, tinha uns moleques, tinha como brincar, tinha como curtir uma infância, isso daí é só no período que a creche ta aberta porque quando você sai pra fora é diferente, lá dentro você tem a liberdade pra brincar com os moleques, jogar uma bola e tal...

R: A creche era um lugar perto da tua casa.?

Em: Na rua de cima...

R: E quem pôs você lá?

Em: A minha mãe me colocou lá mas na época era a irmã J. m. ... 
R: Certo..., e por que era tão bom?; você brincava, tinha amigos, podia...

Em: É tinha amigos, tinha o pessoal, tinha as tias de lá que a gente conversava, a gente fazia tipo gincana, aprendia lá, nós saia da escola, levava lição de casa e lá eles ajudava na lição de casa pra fazer também, era bom, eu gostava....

R: Então tem a creche, tem aqui..

Em: É tem a creche e tem aqui, fora isso não tem muita coisa que eu não convivia com minha mãe, fora isso o que tem de bom é a rua que é a liberdade....

R: Certo..., e qual a pior coisa que já te aconteceu?

Em: A pior coisa é levar um tiro.

R: Por que foi tão ruim?

Em: Sei lá, por causa que, na minha vila todo mundo sabe que eu levei um tiro e muitos me olha, sei lá, me olha assim como se eu fosse marginal e tal, eu tomei esse tiro e eu já tinha saído fora de tudo, e acabei levando esse tiro, mesmo assim o pessoal me olha como se eu tivesse lá dentro as vezes, muitos moleques falam: - E aí meu, deixa eu ver como que ficou a marca do tiro e tal. Muitas vezes me param na rua e falam isso, aí eu não gosto.....

R: É uma marca do passado que você quer apagar...

Em: ....também é uma coisa que é culpa dos outros né meu, é culpa dos outros mas também não é só os outros que tem influência, eu também tava junto também é minha culpa, mas ta bom, ta valendo...

R: Não foi tanto pela dor ou pelo medo de morrer...

Em: Não foi tanto por isso....

R: Foi mais pela discriminação....

Em: Tem sido mais pela discriminação, o pessoal chega, me olha assim, muitas colegas minha que era colega, que a gente andava junto de menino assim, tinha a que eu namorei com ela..., mesmo sabendo na época que eu era do crime, mesmo assim hoje em dia elas tem medo de andar comigo, tem medo de mim.

R: Você queria que essa imagem fosse apagada...

Em: Fosse apagada, porque lá na rua de cima, eu moro na rua de baixo e tem a rua de cima, tem um pessoalzinho, que é os adolescentes da minha idade, que é da minha época, hoje em dia ninguém conversa comigo, ninguém conversa, não para pra conversar, se eu chego assim e começo a fazer uma brincadeira o pessoal começa a sair fora, aí sei lá, fico meio assim, aí neguinho só quer falar comigo pra saber como é que foi levar um tiro e tal...

R: Aonde você levou o tiro?

Em: Na perna...

R: E qual a melhor coisa que poderia te acontecer?

Em: Ah! fazer um aniversário..., comemorar um aniversário.... 


\section{R: Como poderia ser?}

Em: Ah! sei lá...,

R: Quem você queria que tivesse presente?

Em: A família mesmo, é só a família mesmo, porque todo mundo tem aniversário entendeu, só quem teve aniversário foi a minha irmã, foi de 18 anos, eu queria fazer meu aniversário de 15, de 18 não pude fazer...

R: Qual é a data do seu aniversário?

Em: Dia 22 de fevereiro.

R: É você tinha dito...., que mais você gostaria que acontecesse no seu aniversário..., o que seria de mais importante?

Em: De mais importante..., uma garota bem antiga, se tivesse lá também seria a coisa mais importante, aquela menina que eu falei para o senhor, da C. (?), aquela menina lá, nooooossssssaaa, ia ser tudo de bom....

R: É ...., quem você queria que estivesse presente no seu aniversário?

Em: A minha mãe, meus irmãos, meus amigos, que seja amigo mesmo, o W. que é super amigo meu, o D., to falando assim das pessoas que ta na mesma luta do que eu, entendeu?; pessoas que eu conheço, o D. ta na mesma luta que eu, tem um outro que mora lá perto da minha casa e tem uma filha hoje em dia, ta com a mulher dentro de casa, e a gente já fez role junto, já roubou junto, e hoje ta de boa, a gente conversa, a gente pode trocar idéia conversar, é um cara que ta na mesma luta também, é os cara que eu queria na minha festa entendeu?; que é uns cara que ia ta consciente. Só que no lugar onde eu moro não podia ser porque sempre ia ter penetra, como eu moro na favela, os penetras já sabem até quem é...

$\mathrm{R}$ : E qual a pior coisa que poderia te acontecer?

Em: A pior coisa que poderia me acontecer?; acho que perder minha mãe, minha mãe e os meus irmãos...

R: Qual?

Em: Todos...

R: Ah qualquer um, não tem nenhum em especial...

Em: Não tem nenhum em especial, todos eu gosto do mesmo jeito, sei que eu não posso dizer a mesma coisa deles...

R: Você ta convivendo com a tua mãe e alguns irmãos ?

Em: Com a minha mãe e todos os meus irmãos, só falta a minha irmã aí que casou já, tem um filho, eu tenho um sobrinho e tal...

R: Você conhece o gênio da lâmpada né ?; a história do gênio , dos pedidos..

Em: Dos 3 pedidos... 
R: Se você encontrasse o gênio quais os pedidos que você faria?

Em: Aí fica difícil né, tem muita coisa pra pedir...

R: 3 .

Em: $3 . . .$. , deixa eu ver, uma coisa que a gente não pode chegar para mudar de repente assim, todo mundo de rua, mas o que pediria mais normalmente assim era para o país melhorar na questão de rua, entendeu?, de adolescente de rua.....

$\mathrm{R}$ : O que isso afetaria você diretamente?

Em: Afetaria? ah me deixaria mais alegre né meu, pra eu poder passar na rua assim e não ver um moleque tipo usando um barato no meio da rua, um cara deitado, muitas vezes uma mulher com uma criança no meio da rua pedindo dinheiro, eu já tive nessa situação eu sei como é que é, sei que não é muito legal não viu...

Trecho em que os dois conversam ao mesmo tempo e não está compreensível.

Em: Todo muito quer isso entendeu, político quer isso, mas nem todo mundo trabalha, não tem como, aí fica difícil mesmo...

R: E outra coisa....

Em: Outra coisa? Casar..., eu tenho um desejo de casar assim mas eu sou aquele moleque assim meio assim, entendeu..., eu sou meio durão mas todo mundo tem sentimento..., conseguir encontrar uma mina assim que batesse comigo..

\section{R: Como seria?}

Em: Seria assim legal, que pudesse conversar para dividir segredo, essas coisas, que eu mesmo não sei guardar segredo pra ninguém, eu sei guardar segredo de outra pessoa, mas segredo meu é difícil eu guardar, as vezes eu encontro uma pessoa que eu to achando que é bastante amiga, igual o D., ele sabe do que eu faço, sabe muitas coisas aí que eu nem falo pra minha mãe e falo pra ele, porque ele é um amigo meu e ta sempre do meu lado e nunca ouvi sair nada da boca dele pra falar mal da pessoa, entendeu? Tipo assim, casar com uma mulher que pudesse me dar 7 filhos...

R: Tudo isso...

Em: (risos)...só isso né, 7 filhos assim que pudesse me compreender sempre numa hora ruim, a pessoa que sempre chegasse assim em mim e dividisse alegria, a tristeza, sei lá...

R: Fala um pouco mais dela, como você queria que ela fosse....

Em: Eu queria que ela fosse igual a $\mathrm{C}$.

R: Em que aspectos?

Em: Aspectos?; é o seguinte, ela era sossegada, a gente ia pra festa, entendeu, festa que ta um pessoal da pesada, daí a gente sempre tava junto ali, ficava de canto, a gente ia pra praça, dava uns beijos, ficava conversando a maior cara, eu falava o que tava acontecendo na minha casa, ela falava o que tava 
acontecendo na casa dela, o que ta acontecendo de bom o que ta acontecendo de ruim e tal, a gente não ficava parado, entendeu, a gente ficava sempre ali trocando idéia, trocando pensamento...., que eu sei que casamento não dura pra vida inteira, sempre tem um conflito e tal, era muito bom se não tivesse conflito, essas coisas.....

Algumas funcionárias da casa passam pela sala....

R: E o terceiro?

Em: O terceiro? ... ficar com minha mãe pra sempre assim, não separar nem da minha mãe nem dos meus irmãos entendeu? eu sempre falo pra minha mãe assim: - Ó mãe eu não quero casar não viu.... a senhora vai ter me agüentar até a minha velhice, eu não quero me casar, eu vou ficar sempre com a senhora, a senhora vai ver. A sei lá meu, vontade assim, um dia você tem de sair de perto da sua mãe, eu falo perto assim ir pra outro lugar mas.....eu queria ficar com a minha mãe e meus irmãos, ficar do lado deles, eu sei lá, eu sou muito, eu me preocupo mais do que a minha mãe com os meus irmãos, entendeu?; o N., um moreno, que ele é meio agitado, ele tem muita tendência pra poder entrar no crime e tal essas coisas por causa de amigo, ele tem uns amiguinhos que já é ladrão e tal, essas coisas, eu sempre pego no pé dele, falo uma pá pra ele, falo como que eu fiquei e tal e aí a gente conversa e tal e, ele me respeita pra caramba, diferente da minha mãe, as vezes minha mãe fala com ele e ele não respeita entendeu, ele é um molequinho e já não respeita a minha mãe, mas comigo ele atende mais, é um certo medo que eu tenho, medo de deixar meus irmãos de lado e sair de perto deles, deles pegar e ir pra rua, no meio de uma favela, sei lá qualquer hora sai um tiroteio...

R: Se você tivesse uma ilha deserta e você fosse pra lá morar, quem você levaria?

Em: Mais de uma pessoa ou uma?

R: Pode ser mais de uma pessoa.

Em: Minha família...., minha família ....e a garota do meu sonho, só...

R: Só.!!?? E a garota do teu sonho é?

Em: Ah!; não sei, ainda ta no sonho sabe, ainda ta em busca...

R: E se fosse uma pessoa só?

Em: Se fosse uma pessoa só acho que minha mãe...

R: E se você tivesse num navio viajando e ele começa a afundar, o que você faria de imediato?

Em: Se tivesse gente, com bastante gente dentro?; vamos supor com minha família com amigos ?; o que eu faria de imediato?

R: É.

Em: Acho que o que todo mundo faz, todo mundo pra água, sei lá todo mundo pula pra água sei lá, pegar o bote e salvar o importante, a família e os amigos 
que der pra levar, outra coisa não daria pra fazer, não tem muita coisa pra fazer, se você ta no meio do oceano você não tem muita opção do que fazer...

R: $E$ se você encontrasse gente na tua frente com um bote na sua frente, pegando o único bote que sobra...

Em: Ah!; eu não sei eu acho que eu iria ficar desesperado, se não tivesse um lugar pra mim eu ia ficar desesperado...

R: Se você pudesse salvar uma pessoa só, quem você salvaria?

Em: Minha mãe.

R: Sua mãe seria a primeira.

Em: Minha mãe está em primeiro lugar, daria até meu lugar pra minha mãe, como todo mundo diz daria minha vida, porque a minha mãe foi a única que me ajudou a vida inteira, da família inteira os amigos e tal, os amigos ajuda tudo assim, tem amigo que ajuda bastante mas, bastante assim daquele jeito, conversando, as vezes com interesse, as vezes sem interesse nenhum mas não o bastante, mas sua mãe sempre se esforça pra te ajudar em tudo, eu acho que ela teria de ser o primeiro lugar, teria de estar no primeiro lugar em tudo...

R: Agora continuando aqui nos sonhos, nas fantasias, se você ganhasse dinheiro na loteria, muita grana, o que você faria com esse dinheiro?

Em: Primeiramente compraria a casa da minha mãe, segundo..., acho que..., dava um jeito...não vou falar de me tornar empresário mas, tipo assim, de fazer um trabalho grande, um projeto grande meu, tipo um projeto com garotos de rua, um projeto diferente, mas com meu nome entendeu?; um projeto com meu nome, pra ajudar todo mundo e tal e pra mim, uma coisa que eu sempre gostei também, se sobrasse alguma coisinha comprar um pedaço de terra, uma fazenda, é uma chácara, vamos supor comprava uma chácara se sobrasse...

R: Você acha que não sobraria, mesmo que fosse muita grana..., você acha que você ia gastando, gastando e talvez não sobrasse nada...

Em: Não é gastando, eu ia montar uma micro empresa pra mim, primeiramente eu ia comprar uma casa pra minha mãe, por segundo eu ia montar uma pequena empresa..., depois eu ia ajudar todo mundo né, tentar ajudar o máximo que eu puder, porque eu acho que se fosse tipo um milhão, dava para você comprar uma casa de 50 mil, aí ia sobrar 950 mil né, então com 200 mil da pra você montar uma micro empresa, o restante eu montaria projetos, sei lá, montaria bastante projeto, eu não faria o que muitas pessoas faz, chega e compra um bocado de alimento para depois chegar e dar para o pessoal na rua, entendeu?; dá pro pessoal da rua, dar cobertor e essas coisas, eu montaria um projeto com garotos de rua, de periferia, que eu moro na periferia e se eu tivesse a chance de rodar com certeza eu ia abraçar né, a chance de mudar pra mim, de mudar eu e mudar outras pessoas também, com certeza eu ia abraçar esse passo...

R: Você costuma sonhar?

Em: Sonhar..., costumo.

R: Dormindo, acordado?

Em: Acordado..., não costumo muito sonhar acordado e tal mas, é mais quando eu to parado assim entendeu, fico assim no pensamento, pensando quando que eu vou estar independente mesmo, cuidar da minha própria vida, ter 
responsabilidade, eu tenho responsabilidade mas acho que nem tanta assim, às vezes eu penso assim como é que é ser um homem, um homem mesmo.

Algumas funcionárias passam e interrompem nossa conversa por um minuto.

R: E os sonhos que você sonha dormindo, você lembra alguma coisa assim?

Em: Sonho dormindo? Ah!; eu sonho bastante.

\section{R: Você sonha mais sonhos bons ou ruins?}

Em: Ah!; mais bom, bom assim entre aspas porque todo sonho tem uma parte ruim, ele tem uma parte boa e tem uma parte ruim, esses dias ai tem um curso de panificação que eu fiz, esses dias aí eu sonhei com uma senhora, entendeu, com uma senhora que tava no curso de panificação e mora lá perto da minha casa e ia embora comigo, entendeu?; ela é muito legal, tem dinheiro, é rica, mas é uma pessoa que é simples, eu sonhava com ela, eu sonhei com ela várias vezes, encontrei ela, e sonhei com ela conversando assim, sei lá , a gente fazendo um projeto social, eu sonhei com ela (risos) com a gente fazendo um projeto social, a gente tava conversando, foi até aqui no espaço, eu vim pegar umas telas que tem aqui, acabei de pegar as telas e tinha de telefonar pra ela, eu sonhei com ela, eu não lembro direito mas a gente tava com um super projeto social assim com adolescente, sobre um curso de panificação e assim esses dias eu fiquei com ela na cabeça, que eu perdi o telefone dela, aí tem que ir lá no Senai pra mim pegar...

\section{R: E como ela é?}

Em: Ela é uma senhora assim, deve estar com uns 48, 49, mas é uma senhora que é simples, bastante esforçada, sei lá tem uma disposição, tem uma disposição que eu mesmo acho que não tenho, que ela tava fazendo um curso de panificação no Senai à tarde com nós, aí era todo dia, toda semana, de manhã ela tinha um curso de computação 3 vezes por semana, tinha um curso de arte, uma pessoa que mora sozinha e tem dinheiro, o filho dela ta no Japão, e a gente sempre conversando, a gente ia no ônibus ela me mostrava uma foto, eu achava uma coisa legal entendeu, a gente sempre teve uma convivência boa.

$\mathrm{R}$ : E você gostaria de ter uma proximidade maior com ela?

Em: É, eu gostei dela, gostei do jeito dela ser simples, apesar que eu falo, quando uma pessoa tem dinheiro é playboy, todo metido e tal, mas ela é uma pessoa simples, que eu tenho meu jeito de andar, calça larga, camiseta até um pouco antes do joelho, não é ser relaxado, eu tenho um jeito de andar que é diferente do dela, roupa de grife e tal, é uma pessoa que dentro do ônibus o pessoal falava : - O que esse marginal ta fazendo conversando com essa senhora?; é uma pessoa simples...

R: Sei...e tem algum sonho assim que você sonha repetidamente...

Em: Repetidamente, não sei direito, tem é variado assim, mas um sonho que eu sonho desde pequeno mesmo, que eu não entendi até hoje porque, é eu sonho assim que tem um prédio, tem um prédio aqui assim, e não tem um portão tem uma grade assim cercando, mas é tipo vários prédios, tipo uma comunidade, vamos supor um condomínio fechado e aí do lado do prédio tem um matinho e um caminhozinho de terra que dá na grade, é uma coisa que eu já sonhei muitas vezes e até hoje eu não entendi porque. E é uma coisa que eu já vi também, eu 
vi e lembrei, lá em Inácio Monteiro, lembrei dos prédios e do caminhozinho que dá na grade.

R: Essa grade interrompe o seu caminho?

Em: Interrompe o caminhozinho, isso aí eu sonhava desde pequeno, e eu vi um tempo atrás lá em Inácio Monteiro, lugar pra onde a gente ia mudar, que a minha mãe não mudou, e é uma coisa que tipo eu subi o caminho e parei na grade...

R: E qual é a sensação que você tem quando você sonha isso?

Em: Quando eu sonhava isso a minha sensação era pular o muro, pular a grade meu...eu tentava pular a grade mas eu nunca consegui pular...

R: Você tentava pular...

Em: Eu sonhei já uma 5 vezes isso, e eu vi do mesmo jeito que eu sonho eu vi o prédio do lado do prédio o mato e o caminhozinho, lá embaixo tem um matão, em Inácio Monteiro, tem um caminhozinho assim e uma estradinha de barro sobe pra um portão assim é uma grade bem grandona, esses portaozão assim, eu vi assim e lembrei: - Eu já vi isso; aí peguei e fui embora, mas eu não sei o quer dizer, dizem que todo sonho tem um objetivo, mas...

R: Não tem um significado como esses de livro, sonhei com isso é assim, tem um significado que é particular e isso você vai descobrindo junto com a pessoa procurando e ela vai dando o significado do sonho dentro da vida dela...

Em: Certo.

R: Quando você for adulto como você imagina que vai ser sua vida?

Em: Adulto, eu não imagino, eu não consigo me imaginar adulto, eu tenho uma mente assim eu tenho minha responsabilidade eu sei conversar, eu gosto muito de ficar no meio da alta sociedade, conversando com o pessoal e tal, eu acho que tenho palavras pra estar conversando às vezes, mesmo com gente da alta e tal, mas eu não imagino adulto porque se eu to no meio de criança assim, eu me enturmo com elas, eu viro uma criança também, adulto...quando eu me enturmo com adulto eu procuro agir como adulto, entendeu..., mas se eu to no meio de criança eu sou como criança até um certo limite...

R: E. como você acha que é um adulto, descreve o que você...

Em: Adulto..., é uma responsabilidade, muita responsabilidade, sei lá, eu acho assim que adulto é estilo um livro entendeu, um livro que você programa tudo pra poder estar fazendo tudo, se você vai trabalhar a tarde e você tem curso a noite, e ai de repente alguém te liga: - Oh eu quero conversar com você tal hora. Você tem de ir lá no seu livro e : - Oh essa hora não vai dar porque eu tenho de fazer isso e ai você fala: - Não essa hora não vai dar...

R: Programar o seu tempo seria uma coisa bem difícil pra você.

Em: É seria uma coisa muito difícil, estar programando meu tempo, estar programando horário, tem de estar como uma máquina, você tem de fazer..., você tem tempo de fazer tudo mas não sobra um tempo pra você, às vezes até de domingo, minha mãe...ela passa, porque agora meu primo sumiu entendeu, ela passa a semana inteira, ela ta atrás do meu primo e de sábado ela lavou roupa e de domingo ela lavou roupa, ela não tem como fazer nada entendeu, 
minha irmã não tava em casa, ela teve que fazer comida, eu sei lá é diferente, adulto tem...., não consegue um tempo pra você, a não ser que tenha dinheiro né, ou tenha quem trabalhe pra ele, porque se você tiver quem trabalhe pra você ele tem tempo, pobre não tem tempo entendeu? ..., pobre procura um tempo pra conversar, tipo horário de almoço ela nunca tem tempo pra conversar, à noite você chega em casa é jantar, toma um banho janta pra acordar no outro dia pra trabalhar e assim sucessivamente, o dia inteiro a semana inteira...mas eu não sou adulto não, é complicado eu nem sei como falar...

R: Você me disse que gostaria de casar e ter 7 filhos, você tem preferência por homem, por mulher?

Em: Preferência por homem ta, e também quero uma menininhas, mas tenho preferência pelos moleques...

\section{R: Por que?}

Em: Para eu ensinar um pouco o que eu aprendi, e porque eu sou homem também, eu aprendi a andar de skate, aprendi a jogar um pouco de futebol, gosto de basquete, gosto de vôlei também, isso daí não seria muito bom mas..., eu queria ensinar o que eu sei, andar de skate, que eu amo andar de skate, sei lá, ensinar eles se vestir que nem eu, do meu jeito assim, calça larga, tênis, uma boa camiseta, um blusão e tal, queria deixar meus filhos assim né e também eu não tenho uma base correta pra ensinar como é a escola essas coisas, eu não tenho uma base correta pra ensinar porque eu não estudei, eu posso ter daqui uns anos sei lá, se eu voltar a estudar eu posso ter uma base correta para ensinar eles, eu tenho um colega que tem o mesmo jeito que eu, ele tem uma filha e ele convive com ela legalzão, ela vai fazer um ano mas o cara ta feliz, entendeu..., o que mais tirou ele da droga foi a filha dele, sei lá é o que fez ele virar mais homem, hoje em dia ele é outro cara, a responsabilidade que ele tem com a filha dele, ele não sai mais, não vai zoar mais, o máximo que ele ta indo agora é na minha casa, eu sou o único amigo dele e ele é meu único amigo, lá do meu bairro entendeu. Amigo de você estar andando de estar conversando de você ter confiança de andar do lado do cara e saber que você vai chegar lá em baixo e não vai levar um tiro, por isso que eu falo...

R: Você está dizendo que uma criança transforma a vida de um homem.

Em: Transforma, então eu tenho bastante vontade, eu quero ter bastante também porque se um dia eu tiver minha casinha, ver o meu quintal assim, a grama toda..., os moleques..., um jogando futebol na grama o outro brincando de carrinho do outro lado..., era muito bom isso daí..., mas a maioria dessas coisas aí é só sonho, às vezes pode acontecer às vezes pode não acontecer, aí só o tempo mesmo.

R: Você não se sente forte para realizar algumas dessas coisas? Elas estão mais ao sabor do destino?

Em: ... algumas coisas estão mais ao sabor do destino..., então vamos andar pra frente que...quem sabe lá pra frente acontece alguma coisa.

R: Você sabe como é que se gera uma criança?

Em: (Risos), é meio constrangedor mas..., isso daí é questão de pele, tem um relacionamento entre duas pessoas e tal, da minha cabeça assim pra você gerar uma criança é fácil, você sai com a garota e pronto, as vezes você ..., do nada você vai lá a mina ta grávida e às vezes você nem tem uma estrutura básica pra 
estar criando aquela criança, mas é difícil você fazer isso você vai ter de pensar antes...

R: Mas você sabe do que é formada a criança?

Em: (embaraçado) isso é coisa do organismo da mulher..., o esperma do homem e tal, a mulher e tal, aí tem um processo no útero, tem um processo..., isso é mais coisa da medicina né...

R: Mas alguma noção você tem...

Em: Tenho..., aí tem o processo todo mas eu não vou saber falar o nome...

R: Então ta bom, você quer falar alguma coisa?

Em: Não...

R: Bom, podemos conversar outras vezes?

Em: Podemos...

R: Sua assistente social não falou mais nada?

Em: Não, eu conversei com ela hoje...

R: Bem então está tudo certo, eu conversei com a J. (responsável pela Instituição) e expliquei o objetivo e mostrei a autorização da USP ..., podemos dar prosseguimento outras vezes então?

Em: Podemos...

\section{HTP e desenhos livres.}

R: Bem E. hoje é dia?

Em: 3.

R: 3 de dezembro. Então E. eu queria que você fizesse pra mim hoje, alguns desenhos. Não é pra avaliar se você sabe desenhar, é só pra você se expressar e depois eu vou te perguntar algumas coisas sobre os desenhos. O primeiro que eu queria que você fizesse é livre, faça o que você quiser, qualquer coisa, pode fazer....

Em: Vou fazer uma coisa que eu gosto de desenhar.

R: O que é este desenho? Descreve para mim.

Em: Isto daqui é tipo um lago, um lago fundo, uma avenida com obstáculo, uma muralha, este lado aqui uma área verde, uma suposição, deste lado aqui do outro lado da muralha o sol, um fim, um fim da estrada, uma parada.

R: Aqui onde tem o sol que é o fim?

Em: É aqui que é o fim, pra mim é o fim, aqui acaba, não tem como passar isso daqui, como se fosse um quadrado.

R: Como assim um quadrado?

Em: Não tem onde você andar, você só anda até esse limite, não tem como, se você for andar você cai. 


\section{R: Você diria que isto tem alguma coisa a ver com a sua vida?}

Em: Ah, eu sempre desenho isso daqui assim, porque sei lá é uma coisa que eu vejo, como se eu tivesse que parar em um lugar, ter que escolher um dos dois lados, uma lagoa funda ou um meio do mato, uma área verde, como se fosse paraíso e inferno, pensamento só, só ilusão.

R: Sim mas é o que você pensa e nesse sentido é importante...., é como se tivesse o bem e o mal, o paraíso e o inferno.

Em: Correto, é uma coisa que eu estou passando esses dias aí, esses tempos tava tentando ajudar um colega meu e, é uma coisa que eu to sentindo por ele que é o seguinte: eu tava ajudando, dando uma força pra ele, entende, pra mim significa. Tava ajudando ele, ajudei ele até certo limite, daqui eu não consigo passar com ele, porque ele entrou numa errada, foi pra esse lado de cá entendeu!? Ele pendeu pra cá, pro lado de cá, e eu to pendendo pra aqui, pode ser pro bem ou pro mal, pode ser pro crime ou pro trabalho, sei lá. To sentindo muito por causa do camarada meu, entendeu, fui dar uma força pra ele acabei caindo com ele, e ele agora ta na rua da minha casa trabalhando na porta da minha casa e, eu não posso dar nenhuma força pro cara porque eu to com medo de cair de novo.

R: É uma luta com você mesmo.

Em: To mais sentido porque parece que agora ele ta com raiva de mim, porque ele ta pensando que eu to destacando ele, entendeu? To desprezando o cara, mas não é questão de desprezar, é questão que eu não posso ta ajudando ele e arrasando eu, entendeu?

\section{R: E porque você não fala isso pra ele?}

Em: Eu não falo isso pra ele que eu to com medo, porque ele ta no meio da favela, ta trabalhando no tráfico, ele não tava entendeu? Começou a andar comigo, vir pra cá (centro de convivência), ele começou a vir pra cá e, a gente é conhecido desde pequeno só que não trocava uma idéia, aí fizemos uma sintonia, tal e tal conversando e agora ele pegou..., eu tava dando uma força pra ele, ele tava freqüentando minha casa, eu moro na frente da biqueira, começou cumprimentar os caras, agora ta trabalhando com os cara entendeu? E eu to destacando dele, bem dizer eu não deixo mais ele ir na minha casa, entende, que minha mãe não quer ele mais lá, que passa a noite na frente da minha porta trabalhando. Sei lá to magoado, sentido por ele entendeu? Eu ainda estou deste lado aqui, to sossegado, só que eu to com medo de ajudar ele, sendo que eu já recaí porque tentei ajudar ele entendeu. É besteira só...

R: E o que você imagina que tem ultrapassando esse muro?

Em: murmúrio ininteligível...Acho que diferentes coisas, diversas coisas, pode ter um lado bom, um lado ruim, pode ter um obstáculo mais a frente.

$\mathrm{R}$ : E esse muro o que ele é dentro de você? O que você sente como muro dentro de você?

Em: Amizade, amizade, igual eu parei..., eu parei por causa da amizade dele. Até fiquei sem vir pra cá, então eu parei assim dei um breque assim, parei assim no tempo, acabei ficando paradão só pra pensar, pra ver como é que eu podia ajudar ele, entendeu? E não encontro uma solução então...

R: Você acha que uma amizade pode ser um muro pra você... 
Em: É pra mim pode ser, mas sei lá acho que ta sendo um pensamento, to pensando em ajudar ele e to parando pra pensar o que aconteceu e não tenho imaginação pra saber, entendeu...(telefone toca E. fala, não dá pra entender) ...

R: Então você tava dizendo que ta pensando...

Em: To pensando...

R: Mas a amizade pode ser um muro por que ela pode atrasar a sua vida, o interesse em ajudar as pessoas pode atrasar o seu lado.

Em: É.

R: É um perigo.

Em: É um perigo pra mim, então é isso daí que eu to, ...ta complicado. To com medo de ajudar ele, quero ajudar mas to com medo. Quando eu fui ajudar acabei me atrasando, e atrasando o cara também que ele acabou indo na minha casa e eu moro na frente da biqueira, e aí começou parar lá na biqueira, começou a conversar com os caras, e agora ta trabalhando lá..

R: Biqueira o que é?

Em: É onde o pessoal trabalha, assim...

R: Na gíria em todo lugar é biqueira...

Em: Todo lugar, biqueira, bocada, em todo lugar. Sei lá to culpado, entendeu, to me sentindo como se fosse eu que tivesse levado ele pra lá entendeu? Só que não fui eu lá não, ele mesmo foi porque quis.

R: Você quer falar mais alguma coisa sobre este desenho?

Em: Ah! não, este desenho ainda tem muito que continuar.

R: Para aonde ele continuaria?

Em: Não sei, quando eu abrir a mente...

R: Como?

Em: Quando eu abrir a mente ele continua, por enquanto ele vai continuar parado.

R: Você sente que a mente está fechada.

Em: É.

R: Esta estrada também.

Em: É, é isto daí minha mente esta parada do mesmo jeito que esta estrada está bloqueada.

Em: O que quer dizer a mente parada? Você sabe descrever um pouco mais?

Em: Ah! sei lá, não consigo pensar, quando penso não calculo direito o pensamento, entendeu? Não consigo parar o pensamento, ou continuar o pensamento, o pensamento para por si mesmo. Eu to pensando uma coisa de repente to pensando outra.

R: Você não controla, vem outras coisas dentro de você, é isso?

Em: É , como se..., a mesma coisa, eu tando com..., eu to com um pensamento de fazer uma coisa só que de repente o pensamento muda, penso em fazer outra coisa e acabo ficando em duvida qual da coisas que eu faço, qual que é a melhor, entendeu? 
R: Sei, deixe eu tirar este aqui..., agora eu queria que você desenhasse uma casa, do jeito que você quiser.

Em: Uma casa.

R: De quem é esta casa?

Em: Por enquanto é minha, eu que desenhei.

R: Uma casa sua, é uma casa em que você gostaria de morar?

Em: Não sei? Ah! sei lá uma coisa simples, quis desenhar uma coisa simples, uma casa com .... uma caixa d'água, uma TV, portão, garagem, sei lá...

R: Você ..., aqui em cima são caixas d'água.

Em: Claro.

R: A onde fica esta casa?

Em: Ah! não sei, eu só tirei do pensamento isso aqui..., ...tem uma casa de cada lugar...

R: Então, dentro da imaginação mesmo..., não to esperando que você tenha copiado de um endereço, estou falando tudo em termos de imaginação, então assim você pode ter uma resposta pra isso não é: a onde fica essa casa? Quem mora aí dentro?

Em: Eu acho que..., eu caí em contradição.

R: Como assim?

Em: Ah! sei lá, paro um pouco, sei lá minha família, eu, uma amiga, sei lá.

R: Uma amiga?

Em: Ah! pessoas né, ...sei lá eu, minha mãe, minha família, irmãos.... (SUSPIRO).

$\mathrm{R}$ : Ta te angustiando?

Em: Não, desencanado, sei lá coisa simples que..., sei lá às vezes pode ter significado pode não ter, pra mim.... tanto faz como tanto fez eu morar numa casa grande ou numa pequena...

R: Mas seu sonho seria qual?

Em: Sei lá, ter meu lugar, ter meu espaço.

$\mathrm{R}$ : O que você poria dentro dessa casa?

Em: O que eu colocaria? Não sei..., em termos de gente?

R: O que você quiser.

Em: Sei lá colocaria um cão, uma mulher, uma criança, sei lá. Uma responsabilidade por exemplo.

R: Uma responsabilidade !?

Em: É.

R: Como assim?

E: Sei lá alguma coisa que eu goste, que eu tenha amor, entendeu, que eu tenha deveres com ela, tenha deveres e sugestões.

R: Algo por que se responsabilizar. 
E: Algo com que eu goste de me responsabilizar, entendeu? Não coisas que eu seja obrigado a ser responsável por elas.

$\mathrm{R}$ : O que falta nesta casa?

Em: O que falta? Acho que..., sei lá um quarto pequeno, não sei o que faltaria pra completar, sei lá um quintal nos fundos, uma área que saísse pra uma rua, casas ao redor.

R: Mais alguma coisa?

Em: Sei lá amigos, crianças.

R: Agora eu queria que você me desenhasse uma árvore.

Em: Uma árvore.

R: Que árvore é essa? De que tipo?

Em: Uma árvore frutífera..., maça, ou pode ser pêra, uma arvore que dá frutos.

R: Qual a idade dela?

Em: Sei lá, acho que, do meu ponto de vista, do meu conhecimento, uns 4,4 ou 5.

R: 4 ou 5. O que é este negócio no tronco?

Em: Ah só um...a maioria das árvores tem, uma bolinha, um buraquinho...

R: No caso dessa, o que é isso?

Em: Eu acho que é somente um machucado, alguma coisa entendeu?

R: Um machucado...

Em: É, uma ferida.

R: Uma ferida.

Em: Ah! sei lá eu falo assim em termos de, isso é em humanos, não sei como chama em árvore...

R: Certo, um machucado.

Em: Um machucado.

R: Ela ta sozinha?

Em: Risos... No papel sim...

R: Mas na sua imaginação você imagina ela sozinha?

Em: Por enquanto sim, na minha imaginação sim, não tem uma coisa perto, a não ser que tenha longe.

R: E você acha que falta alguma coisa pra ela?

Em: Pra ela? Um tratamento..., um dom, alguma coisa especial, não..., um tratamento, uma pessoa que cuide..., não sei se você me entende?

R: Entendo...

Em: Sei lá que tudo na natureza também se cuida, coisa que muita gente não faz hoje em dia, só faz matar, então..., mas não tem significado nenhum...

R: E que dom seria esse? 
Em: Sei lá, acho que, já pensou um dom de poder dar dois frutos, depois, sei lá, em vez de ser sozinha, fazer uma coisa só, entendeu? Podia fazer múltiplas coisas, dar múltiplos frutos...

R: Sei.

Em: Ou quem sabe se mover de um lugar pro outro.

R: Quer falar mais alguma coisa dela?

Em: Não.

R: Agora, terminando..., eu vou virar a fita;...bom eu queria que você desenhasse uma pessoa.

Em: Pessoa..., uma ou mais de uma?

R: Uma só.

Em: Eu sei que não está parecendo muito com uma mulher mas..., pode ser só um rosto?

R: Como você qui...você pode desenhar o corpo?

Em: Posso.

Em: Ai cara eu não sei desenhar não...

R: Eu não to avaliando sua capacidade de desenho...

Em: Esse negócio de desenhista pra mim nem é importante, ...bom pra mim eu terminei, vou só dar um jeitinho aqui, ta parecendo homem mas...

R: Quem é essa pessoa?

Em: Uma colega..., (risos)... desenho mais feio...

R: Que idade ela tem?

Em: Ela tem 18.

Alguém entra na sala pra pegar um objeto e E. brinca: -Hoje eu que estou entrevistando ele.

R: Então quem é essa pessoa.

Em: Uma colega.

R: Que colega é?

Em: É uma pedagoga, gente boa...

R: Como ela é?

Em: Ela não é magrinha assim, ela é meio gordinha mas....é gente boa, é minha ex-namorada..., que eu vi ela ontem, e isso fica complicado pra mim, isso traz complicações...

R: Que complicações?

Em: Porque ela é minha ex, não é mais minha, é minha ex.

R: E qual a idade dela?

Em: 22, 22 anos.

R: O que ela gosta? 
Em: Ela dizia que gostava de mim, agora não sei se ela gosta mais. Ela gosta de computadores, gosta de esportes, esporte dela é vôlei, andar de bicicleta, isso é o esporte dela. (me pareceu meio irônico)

$\mathrm{R}$ : $\mathrm{E}$ isso é ruim?

Em: Não.

R: E do que ela não gosta?

Em: O que ela não gosta? Cara não cheguei nesse ponto..., de saber o que ela não gosta, tem algumas coisas que ela não gosta; ah! que deixem ela pra baixo, uma coisa que ela não gosta, que rebaixem ela, entendeu? Não sei se você me entende?

R: E o que é isso aqui no joelho, na perna dela?

Em: Ah eu ia fazer um joelho aqui, eu....só deixei assim...eu costumo fazer o joelho bem fraquinho assim, o joelho tem de ser bem fraquinho por causa ...

R: Como assim?

Em: Sei lá, pra você desenhar assim...

R: Sei bem de leve...

Em: Bem de leve, só pra deixar uma sombra...

R: E. me desenha uma pessoa do sexo oposto.

Em: Sexo oposto? Ah! eu acho que..., eu vou desenhar só eu mesmo.

R: Como você quiser.

Em: Ta aí...

R: Quem é?

Em: Esse sou eu...feio mas...

R: Com quantos anos você está aí?

Em: To com meus 18, igual hoje.

R: 18 como hoje. E o que são essas letras?

Em: Periferia, jovens, trabalhadores....

R: Periferia, jovens, trabalhadores...E o que você neste desenho, você sente falta?

Em: Sinto falta do 'que eu uso hoje', do que eu não uso mais hoje, as letras...

R: O que?

Em: As letras..., hoje eu falo periferia, jovens, trabalhadores, antigamente quando a gente pichava, eu e a galera, era periferia, jovens, traficantes...

R: Mas eu não entendi, o que você sente falta?

Em: Sei lá, não é que eu sinto falta assim, eu mudei entendeu, o texto de traficante pra trabalhador, então eu sinto falta de quando eu era traficante, era tudo mais fácil, era brincadeira, a gente zoava, era adrenalina, entendeu? Hoje eu só trabalho, do trabalho pra casa, de casa pro trabalho, eu trabalho aqui assim, dou a maior força pro pessoal aqui, entendeu, mas, sei lá, mas eu gosto..., e o skate é uma coisa que eu amo ainda, até hoje, desde pequeno.

R: E do que você não gosta? 
Em: Do que eu não gosto? Deixe eu pensar...Eu não gosto de ser superior aos outros e nem inferior a ninguém entendeu? Eu gosto de ser eu e que ninguém queira se superior a mim e nem gosto de ser superior a ninguém.

R: O que é isso ai que você ta fazendo na altura do joelho? (no desenho).

Em: Isso é um rasgo na calça e tal, um zíper, posso colocar um zíper, calçabermuda.

Segundo desenho livre.

R: Bom E. um ultimo desenho, me faz um outro desenho do jeito que você quiser.

Em: Um outro.

Em: Já fiz.

R: O que é isso?

Em: Um adolescente atrás de uma cerca com arame farpado, com uma pequena bola de meia nos pé.

R: Quem é esse adolescente?

Em: Um adolescente...

R: O que ele está fazendo aí? Ta preso? Isso é uma prisão ? É o que? Essa cerca é o que?

Em: Sei lá pra mim é uma prisão entendeu? Sabe, eu sinto assim como se fosse uma criança que aliás entrou numa prisão, que nunca saiu de uma prisão, entendeu?

\section{R: Não quer sair!!!?}

Em: Não saiu, então quer dizer que ainda ta com a bola de meia, só que ela nunca vai brincar do lado de fora, entendeu? Nunca vai conhecer ninguém, nunca vai ficar com ninguém .... lá dentro é só falsidade, com quem você brinca é só falsidade, todo mundo tem a falsidade, todo mundo tem maldade pra te pegar, entendeu? Qualquer coisa é motivo de briga, de morte, então ele fica sempre do lado da cerca, olhando do outro lado.

R: A cerca protege...

Em: Acho que sim.

R: Mas a onde estão essas pessoas que são falsas? Do lado de dentro ou do lado de fora?

Em: Ambas as partes, do lado de dentro e do lado de fora. Do lado de dentro tem mais, entendeu. Do lado de fora tem gente sincera e tal, só que não sei se você viu o detalhe, a cerca só ta aqui, não ta aqui, então ele não se movimenta dela, não sai fora.

R: Mas tem saída.

Em: Mas tem saída, sei lá essa criança é igual eu entendeu? Eu to lá, eu to lá dentro, eu não tive uma infância, minha infância continuou lá atrás, então ela continuou lá atrás e não vai poder sair mais, entendeu, agora eu cresci e sou homem, não vou poder mais ter uma bola de meia, bola de couro, então..., igual eu falei no começo pra você, ele tava fora e acabou sendo preso lá dentro, 
entendeu, com as drogas, só que a criança não consegue sair de lá, e agora quem ta fora é outra pessoa, não é mais essa criança que ta lá dentro, e às vezes eu mesmo tenho medo dessa criança sair pra fora. Essa criança ainda tem a mesma aparência de antigamente, então...

R: Ela pode destruir...

Em: Ela pode me destruir, então eu prefiro que a criança continue lá dentro, sou criança ela é um pré-adolescente, só pensa em farra, em zoeira, em balada, então é risco ela sair pra fora e é legal se ela sair pra fora, só que eu prefiro não correr o risco. Sábado passado eu fiz isso, entendeu? Deixei ela se libertar um pouco, curtir e tal, fui pra quermesse, bebi e tudo, só que eu vi que na hora que eu bebi, que eu tava tipo, não tava bêbado, tava consciente, só que a criança já tava do lado de fora entendeu? O negócio que passou na minha mente só foi maldade, me desentendi com meu melhor amigo que ta aqui fora, quis catar ele, quis catar os moleques, dei cabeçada num moleque lá por nada, entendeu? Pensando que eles estavam me tirando, então essa criança é revoltada, então....ela tem de continuar lá dentro, lá atrás.

R: É isso que te salva!!!?

Em: É isso que me salva, só que às vezes é chato ficar só sendo responsável, ter seus negócios e não encontrar uma diversão entendeu? Diversão você tem em todo lugar, só que diversão igual antigamente, igual essa criança curtia..., não existe.

R: Bom E. quer falar mais alguma coisa?

Em: Não..., a criança continua lá dentro e eu aqui fora.

R: Então terminamos por hoje, obrigado. Eu ainda tenho mais um dia que eu gostaria de conversar com você, tudo bem?

Em: Certo. 

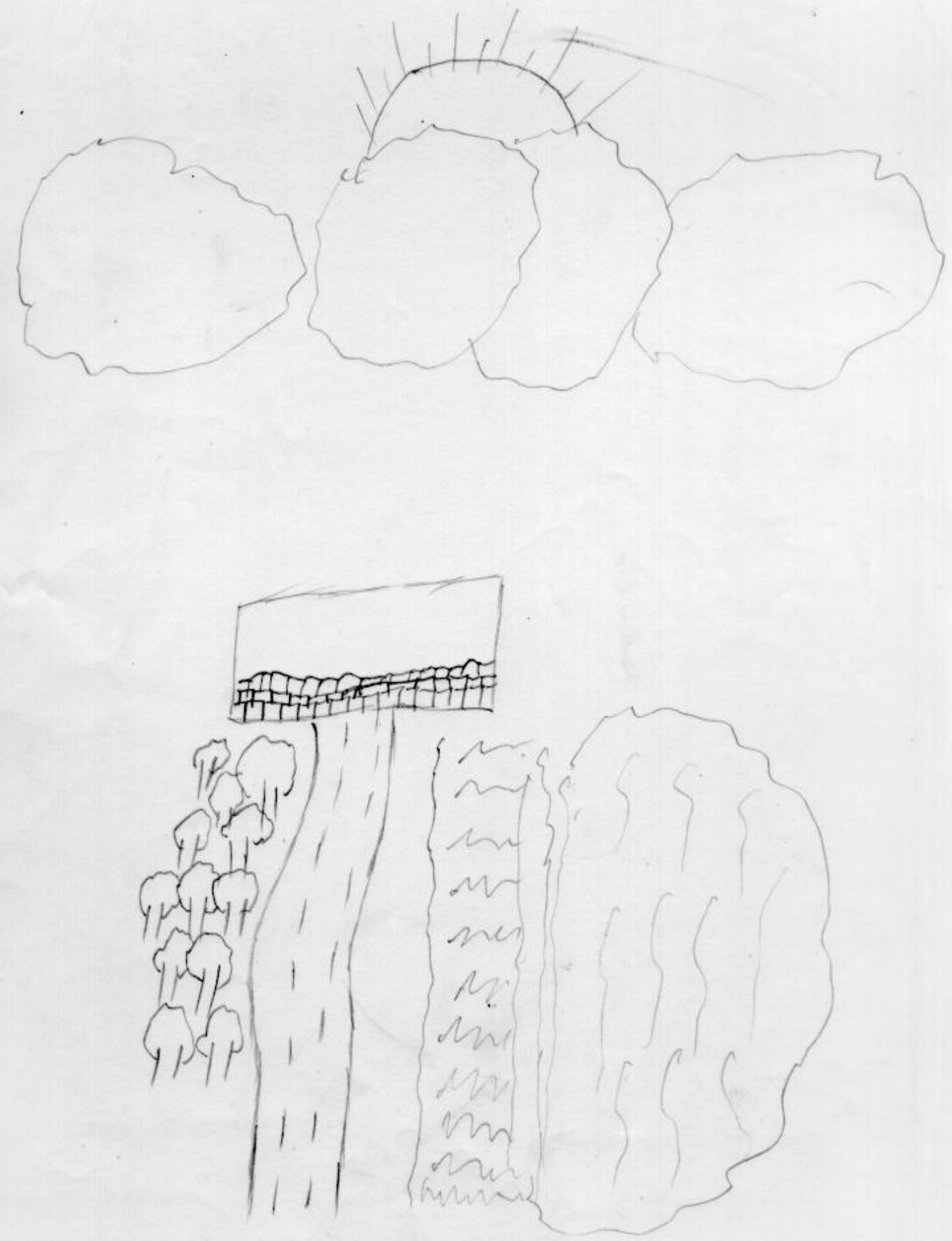

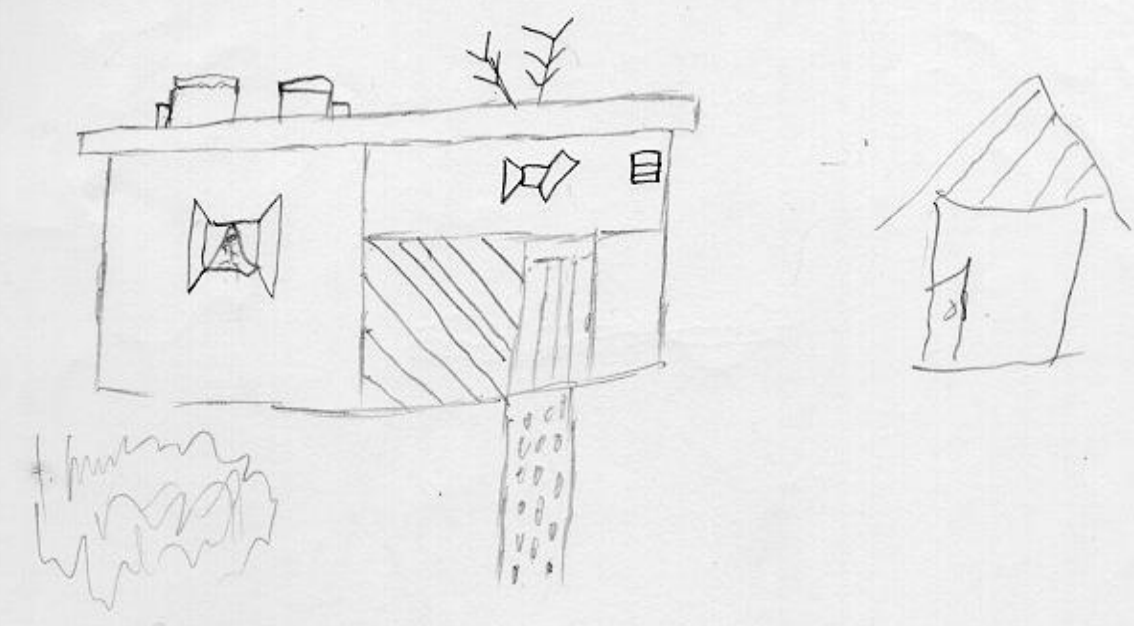

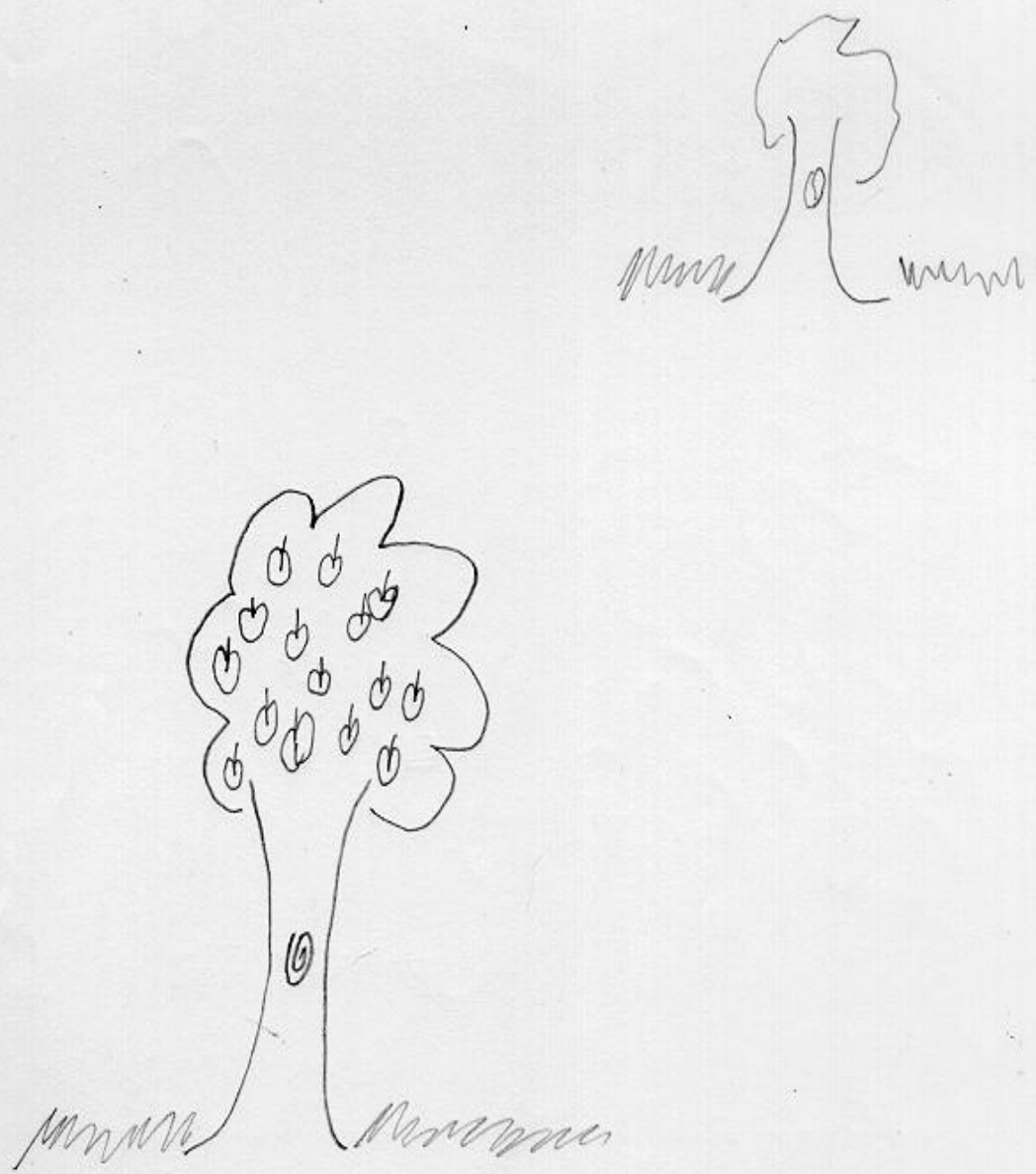


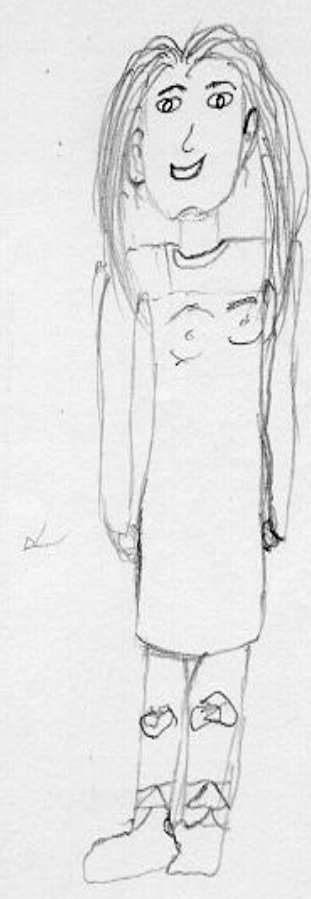




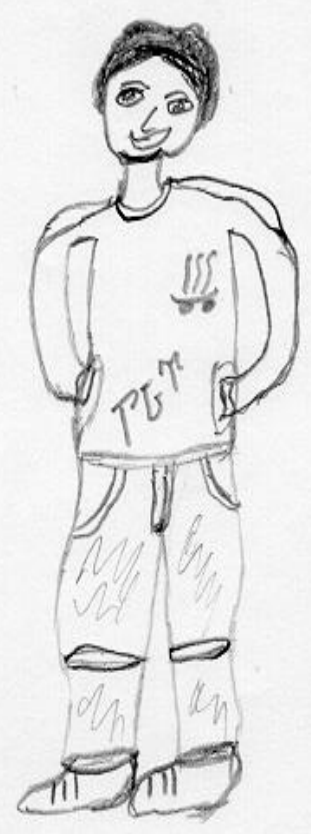




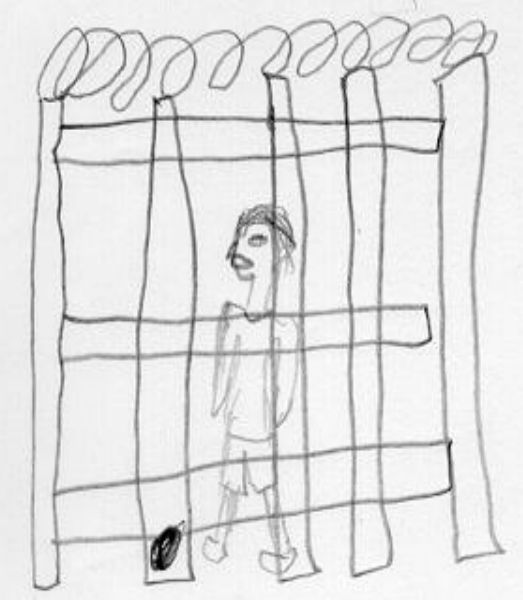




\section{TAT}

R: Bom E. estamos aqui novamente nós dois, dia 7 de janeiro de 2004, a ultima vez que a gente se encontrou foi antes do Natal não é?

Em: Foi, uma semana antes.

R: Bom então hoje E. Eu queria fazer a ultima entrevista com você, digo, talvez a ultima porque depois vou analisar e se faltar alguma coisa, uma perguntinha ou outra, mas é muito rápido.

Eu vou te mostrar umas folhas e vou querer que você me conte uma estória em cima destas folhas, da tua imaginação, sem censura, não se preocupe com a realidade.

Em: Ta. Uma estória assim verbalmente?

R: Isso, prancha 1 . O que você vê aqui?

Em: Um garoto e um violino.

R: O que ele ta pensando. Pode por sua imaginação pra funcionar.

Em: Pela expressão do rosto e da mão, desistência, desistiu de tocar, não sei, teve dificuldade, não consegue avançar, acho que é uma coisa assim. Ta parecendo um garoto inocente, pequeno, aí é um começo, quem sabe se ele vai conseguir tocar...

R: E qual foi a experiência dele antes, o que levou ele a esta situação?

Em: Ah!; penso assim, uma falta de cooperação com ele, faltou alguém ta ajudando ele, ta envolvendo ele com o violino, ele tentou sozinho e não conseguiu.

R: Falta de apoio.

Em: Falta de apoio.

R: E nesse momento a expressão dele pra você é de um certo desanimo?

Em: Desanimo, olhando, pensando desisto, não desisto.

R: E como vai terminar essa estória?

Em: Aí fica difícil, eu mesmo me colocando no lugar dele, do meu estilo do meu jeito, eu acho que eu desistiria, sem apoio.

R: O apoio é fundamental.

Em: É mas é só uma figura!!!!

R: É , é só uma figura. Você acha então que ele vai desistir.

Em: Acho que ele vai desistir.

R: Só não fala baixo senão não grava aqui.

Em: Eu acho que ele vai desistir, não vejo uma expressão de ainda ter uma certa vontade de continuar.

R: Certo, mais alguma coisa?

Em: Não.

R: Vamos pra próxima. Prancha 3 MF, o que você vê aqui? 
Em: Uma mulher, uma porta, a mulher com a mão no rosto, eu acho que triste com alguma coisa.

R: Espera aí, repete, fechando a porta...

Em: Fechando a porta com a mão no rosto, eu acho que chorando, a expressão do corpo triste, alguma coisa assim.

R: Perda!?

Em: É.

R: O que é, então diz qual o conteúdo aí. O que ta acontecendo. A estória é sua, você pode por o que você quiser. É como um filme, ou um livro.

Em: Um filho.

R: Um filho.

Em: Perda de um filho, em infeliz circunstância.

R: Que tipo de perda do filho?

Em: Uma mudança.

R: Em que sentido?

E. Uma mudança de reação...

R: Mas então fala a estória, imagina a estória, o que aconteceu?

Em: Ah!; vamos lá, eu to vendo assim como se ela estivesse fechando a porta, como alguém tivesse saído e ela tivesse achando..., chorando..., querendo que voltasse.

R: Essa pessoa que saiu é quem?

Em: É o filho dela.

R: Ele saiu pra onde?

Em: Ah!; pra rua, sem destino, sem rumo.

R: E qual o motivo dele ter saído?

Em: Motivo? Rebeldia. Acho que rebeldia e amizade.

R: E ela, ela se sente responsável pela saída do filho ou não?

Em: Se sente, pelo menos aqui ta se sentindo, nessa foto.

R: E como ela foi responsável nessa estória, pelo filho, pela ida do filho.

Em: Acho que o cuidado com ele. Às vezes deixar ele trancado ou deixar ele na rua. Ou poderia ser o marido dela, ou um familiar...

R: E dizendo..., continuando na estória do filho, o que aconteceu logo antes dessa, desse momento aí?

Em: Acho que discussão.

R: Sobre o que?

Em: Acho que sobre ficar na rua, os amigos, o filho sai, bate a porta, ela fala com ele, ele pegou virou as costas, ela falando com ele ali ele virou as costas e foi embora.

R: E como vai terminar essa estória?

Em: Ah! pra terminar essa estória... 
R: Pensa sempre que é como um livro, como se você tivesse montando, como você terminaria essa estória?

Em: Terminaria com um amigo na porta dela, trazendo o filho dela e o filho dela compreendendo.

\section{R: Compreendendo o que?}

Em: Acho que compreendendo a mãe dele, vendo que ele tava errado, por problemas na rua, ele saiu na rua e viu alguma coisa que não gostou, viu que era tudo o que a mãe dele falou, volta pra casa, um amigo traz ele pra casa conversando com ele, e aí os dois conversam e a estória continua com os dois mãe e filho com a vida normal.

\section{R: Prancha 7RH. O que você vê aí?}

Em: Pai e o filho conversando, acho que sobre negócios.

R: Que negócios?

Em: Pai de gravata, filho de gravata (observando), conversando sobre trabalho.

R: O que ele estão conversando?

Em: Isso é o que eu tenho que ver...

R: Deixa sua imaginação solta. Não se preocupa muito em ter lógica não.

Em: Eles estão conversando sobre verdade, sobre um trabalho, sobre emprego, não ficar em casa.

R: Quem que fica em casa?

Em: O filho. O pai dele ta pegando no pé dele, a expressão do rosto dele aqui ta meio tipo : - Não to gostando. Pai conversando com ele calmamente e ele não entende.

R: Não ta aceitando.

Em: E ele não ta aceitando.

R: E como vinha a estória antes de chegar nesse momento?

Em: Nesse momento? Acho que o garoto, o pai sempre dando um apoio, dando uma chance pra ele, ele sempre pisando na bola, sempre desrespeitando o pai, o pai gosta muito e antes deveria, acho que ficava em casa parado, sentado assistindo, ou fazendo alguma coisa que não deveria na rua, e o pai tentando dar uma força pra ele trabalhar, e o pai sempre vinha conversando com ele e aí chegou a hora final de conversar com ele e saber o que ele quer da vida.

R: E como vai terminar essa tua estória?

Em: O filho conseguindo um emprego, saindo de casa, alugando um apartamento e deixa o pai de lado.

R: Ele ta meio cansado da pressão do pai?

Em: É, eu acho que é assim, é ..., meio cansado da pressão mesmo.

R: Mas eu pus palavras na tua boca...

Em: Não...

R: Por que ele sairia de casa? 
Em: Ele sairia de casa mais pela pressão mesmo, o pai sempre tava pesando na dele e ele assim que conseguiu o serviço abandonou o pai, deixou o pai pra lá, bem dizer não vou falar esqueceu o pai, mas foi morar, foi fazer sua vida...

R: Magoado com o pai.

Em: Magoado com o pai só que sempre pensando que o pai dele estava certo e que era o melhor pra ele.

R: Prancha 8RM. Diga o que você vê nessa prancha.

Em: Pelo dia..., vejo uma espingarda, uma faca, dois delinqüentes e um engravatado, o mandante.

R: O engravatado é o mandante?

Em: É.

R: Mandante do que?

Em: Aqui eu estou vendo eles cortando a barriga do cara.

R: Com que intenção?

Em: Um copo, talvez um copo.

R: A onde?

Em: Aqui (mostra na figura).

R: Qual a intenção de cortar a barriga do cara?

Em: Acho que traição, traição de um amigo...

R: Então eles estão querendo vingança!!!!? Matar o cara. O corte não é pra operar não é pra..., é pra matar o cara.

Em: É, matar.

R: Por motivo de vingança.

Em: Porque aqui também tem a janela, como se fosse uma viela.

R: Eles encurralaram o ...

Em: É.

R: E o que o cara fez?

Em: O cara fez, ser besta, ser muito amigo do cara que não valia a pena ser, o cara do homem de gravata, conversar, criar ambição, e ambição... ?

R: E a ambição o que?

Em: Cegou os olhos do colega, o colega mandou matar, vamos supor assim pra ficar com a fortuna...

$\mathrm{R}$ : Ah! esse aqui que é o rico, o que ta morrendo que é o rico.

Em: Esse aqui é o rico e esse aqui é um amigo rico também.

$\mathrm{R}$ : Mas ele cresceu o olho em cima...

Em: Cresceu o olho em cima do outro, do amigo rico que tinha alguma coisa.

R: E esses aqui são?

Em: Os capangas. 
R: E como vai terminar essa estória, ele vai morrer, não vai, como é que vai ser? Como você terminaria essa estória?

Em: Eu terminaria com os dois que mataram presos, com o mandante perdendo tudo, sendo preso, chegando na cadeia, refletindo, vendo o que ele fez, que a ambição dele não levou ele a nada, e reconhecendo que o cara que ele mandou matar era realmente um amigo dele, dentro de uma cadeia, bem escura e sofrida...

R: Arrependido.

Em: Arrependido.

R: Prancha 9RH. O que você vêaí?

Em: Uns caras, uns homens descansando, ou mortos...

R: Ou o que?

Em: Não, descansando eu acho e um homem olhando...

R: O que você tinha dito?

Em: Mortos.

R: Ah!

Em: Mas não ta parecendo, estão descansando, tem uns descansando e um homem olhando pra eles.

R: E o que é essa situação, como eles chegaram aí? O que...

Em: Eu vejo bastante grama, eu acho que... trabalho, suor, uma lavoura, vamos colocar assim, trabalharam bastante e estão descansando e um, vamos supor, um empregado do patrão olhando.

R: Olhando por que?

Em: Eu acho que por não gostar deles, de ver eles assim parados.

R: Mas eles trabalharam.

Em: Mas eles trabalharam?

R: Qual o clima entre eles?

Em: Ah!; a diferença aqui é o um que não trabalhou que não ta gostando de ver os que trabalharam parados, por ordem de um patrão, ou por ordem dele mesmo, e os homens dormindo e ele olhando como se tivesse com trairagem com eles, como se tivesse assim pensando: - É eu vou falar pro patrão pra despedir eles então.

R: E como vai seguir essa estória.

Em: Essa estória acho que seguiria assim..., seguiria o rapaz que ta olhando pros outros dormindo, empregado do patrão deles chegar e conversar com o patrão deles, falar isso. o patrão dele despedir ele, mandar ele procurar outro serviço porque os outros mereciam, eles merecem estar descansando porque trabalharam.

$R:$ Certo, só? 


\section{Prancha 13 HF. O que você vêaí?}

Em: Um homem levantando pra ir trabalhar, uma mulher na cama dormindo, a mulher dele, um pai de família, vejo um quadro, um livro, uma cama...

R: Esse homem esta saindo pra trabalhar, ele tem família alem dessa mulher dele?

Em: Eu imagino que não, acho que não, to vendo aqui uma coisa pequena, tipo vamos colocar assim, antes disso, eu acho que assim uma estória...

R: Que estória?

Em: Como se ele fosse um antigo garoto que viveu em abrigo, essas coisas, ta começando uma vida, com uma casa pequena, uma pequena mesa, um quadro, uma cama de solteiro, com a sua mulher, e conseguindo, saindo pra procurar um serviço, ou saindo pra ir trabalhar...

R: E aí, como vai terminar?

Em: Terminar indo ele pro serviço, o dia dele sendo cansativo, chegando em casa, todo dia a mesma rotina, chegando em casa, conversando com a mulher, tendo um diálogo, jantando e novamente dormindo pra começar outro dia, e às vezes no final de semana quando para, se divertir, e uma hora parar, parar na sua casa, numa folga, olhar assim, lembrar de trás, da época antiga e ver que ele mudou, e que ele está sendo aceito na sociedade...

\section{R: Prancha 14. O que você vê aqui?}

Em: Uma casa escura e um homem pulando pra fora da janela.

$\mathrm{R}$ : Pra onde ele vai? O que aconteceu antes e pra onde ele vai?

Em: Um roubo. É o filho..., antes ele, ele é o filho da dona da casa, ta levando alguma coisa, algum objeto, saindo pra rua...

R: Ta roubando da casa...!!!

Em: Ta roubando da própria casa, da mãe, saindo pra rua pela janela, pulando a janela, com as luzes apagadas, com a mãe dormindo, pra poder ir curtir a noite e do jeito que..., usando drogas...eu acho que só...

\section{R: Última prancha, prancha 16. O que você vê aqui?}

Em: Aqui eu vejo sei lá acho que um vazio, uma..., um branco, alguma coisa, uma coisa que não tem nada, um começo de uma vida, de uma nova vida, ou o esquecimento de uma antiga vida, e eu acho que aqui falta alguma coisa ainda, falta, vamos colocar um ponto no meio pra poder abrir, pra poder começar, aqui falta um começo ainda, falta uma mão.

$\mathrm{R}$ : Como seria esse ponto? O que seria esse ponto?

Em: Esse ponto para mim seria uma mente aberta, uma mente aberta e força de vontade.

R: E o que aconteceu pra chegar nesse..., aí é um ponto de partida e um esquecimento, ao mesmo tempo as duas coisas...

Em: É, vamos colocar assim, o esquecimento é um..., vamos supor, aqui ta um papel branco, antes vou colocar como se tivesse um papel totalmente preto, 
passado negro, que ele conseguiu esquecer e arrumar tudo o que teve, arrumar as coisas que teve no passado e agora no futuro ta tentando, ta pensando pra conseguir alguma coisa, absorver coisas pra poder ta colocando no futuro dele.

R: E essa mente aberta que você fala, como é..., ela é possível de ser conseguida? Como é ? Se é possível depende do que?

Em: Eu acho que é possível ter a mente aberta pra você poder aceitar correções, poder aprender bastante coisas, pra poder conseguir colocar alguma coisa nesse papel, para poder colocar 4 fotos, 4 fotos do seu futuro.

R: E o que teria em cada uma dessas fotos?

Em: Uma teria o serviço, uma teria, primeiro teria a mãe e os irmãos do lado, a segunda foto pra mim teria o serviço, a terceira foto uma casa, uma casa seu carro, quarta foto teria sua mulher e sua filha do lado.

R: E essa mente aberta ela depende de alguma coisa pra ser conseguida? E se depende do que ela depende?

Em: Acho que ela depende sim mas acho que ela depende de força de vontade, e alguém que possa estar, e gente que possa estar com vontade de ajudar você, e que você esteja com vontade também de ser ajudado, falta força de vontade.

R: E. a gente está terminando e eu só queria te fazer duas ou três perguntas. E. me diga uma coisa, na sua opinião o que a sua mãe deixou de mais importante pra você?

Em: Pra mim, essa pergunta é difícil pra lembrar alguma coisa importante. Ah!; me colocou no mundo, acho que de importante que ela me deixou foi minha educação, alem de tudo o que eu tive na vida, foi a educação que ela me deu, a coisa mais importante que ela deixou...

R: E como você diria que é essa educação?

Em: Eu posso ter passado de tudo, mas minha mãe sempre me ensinou a respeitar as pessoas, chegar num lugar e saber como, saber que nem todo lugar é, um é dum jeito, todo lugar é diferente, e saber como..., ela me ensinou como estar lidando em cada lugar que eu chego, graças a Deus foi uma coisa que ela me deixou que eu agradeço até hoje.

$\mathrm{R}$ : E de ruim, você acha que ela te deixou alguma coisa?

Em: Minha mãe..., eu não posso falar que ela me deixou nada de ruim, mas eu falo assim porque..., ela me deixou ..., num certo ponto ela me deixou solto, uma coisa que é meio de ruim, uma coisa que eu acho ruim assim, é a lembrança de não ter tido lembrança de eu conversando com ela, um diálogo, de alguma coisa, de algum problema meu, de algum problema dela, é a lembrança ruim que ela me deixou.

R: E o teu pai, você acha que teu pai te deixou alguma coisa?

Em: Ah meu pai não me deixou nada, meu pai eu não convivi com ele. Às vezes que eu fui lá na casa dele, aquela vez que eu viajei, que fui lá na casa dele, igual eu contei antes, não cheguei a conversar com ele muito, poucas vezes, só oi e tchau. Assim meu pai não me criou, meu pai não tem nada a ver com minha vida.

R: Ele te deixou muita raiva numa parte da tua vida...

Em: Numa parte..., bastante...

R: E hoje? 
Em: Hoje eu não ligo, não ligo pra isso. Eu sou indiferente, eu não ligo. Antes eu pensava muito em ir pra pegar ele, fazer alguma coisa com ele, aí depois eu conheci ele e sei que não vale a pena fazer nada, porque eu também não vou ganhar nada nisso, então pra mim tanto faz, ele é neutro pra mim, pra minha vida é neutro.

R: Antes você tinha raiva dele, você achava que ele te deixou, e hoje mudou alguma coisa teu jeito de entender as reações dele?

Em: Mudar mudou assim, mudou porque eu sei que ele tem a vida dele e tem a mulher dele, ele gosta de outra mulher, não gosta mais da minha mãe, então assim, eu não tenho amor por ele, é meu pai e tudo mas eu não desprezo ele, se ele falar comigo eu falo com ele. Eu acho assim que pra mim tanto faz se ele falar comigo, tanto faz se ele não falar. Acho que eu não aceitaria um presente dele, nada dele não aceito, não aceitaria de jeito nenhum, nada, pra mim é como se ele fosse somente conhecido, eu passo falo oi e tchau, não tenho nada contra ele e não tenho nada a favor dele.

R: Você diria que..., que pessoas foram marcantes na tua vida.

Em: Pessoas que foram marcantes na minha vida..., um amigo que foi o $\mathrm{J}$.

$\mathrm{R}:$ J.!!!?

Em: É oJ.

R: E por que ele foi marcante?

Em: Foi marcante porque foi um cara que, foi o único amigo que foi amigo mesmo, não me levou pras drogas, sempre me levava na Igreja, a gente conversava bastante..., então eu acho assim, foi meu amigo, amigo do coração mesmo, a gente sempre ia pra Igreja junto quando era pivete, eu sempre tava no meio da rapaziada e ele ia me tirar e a gente ia pra Igreja junto, sempre eu..., já cheguei chorar do lado dele, a gente trocar idéia, conversar, quando era pequeno, ele sabia meus problemas e tentava me ajudar, foi um amigo que até hoje eu não esqueço, faz anos que eu não vejo ele, que eu não tenho noticias mas..., foi um cara que marcou, ficou no coração mesmo, como um irmão.

\section{R: E de quem você tem a maior mágoa?}

Em: Ah eu acho que eu tenho mágoa só de mim mesmo, do meu passado, de eu ter sido burro, não te pensado, não ter reconhecido, ter visto..., muitas vezes eu fazia burrice, sei que o negócio não tem futuro, pegava ia lá pra tirar um $A Z$, ia lá e fazia as coisas erradas, ia lá e usava uma coisa errada, contra a minha própria vontade eu ia lá, só por ir, pra não ficar destacado das outras pessoas, só pra não ficar destacado dos amigos que eu tenho hoje.

R: Ta bom E. acho que é só mesmo, então obrigado. 


\section{ANEXO 3}

\section{Sujeito F. ( masculino)}

\section{Primeira entrevista:}

R: Hoje é dia 2 de janeiro de 2004, eu estou aqui com o F. Como é seu nome inteiro?

F: F...

R. F.., ta. E hoje é o primeiro dia que nós vamos conversar e eu vou começar a primeira entrevista aqui com o F. Eu vou pedir pra você falar alto e claro, aqui tem um microfone (mostrando no gravador), então o que nós formos conversando isso vai ser gravado e depois eu vou transcrever. Como eu te falei, as informações aqui são confidenciais, ninguém vai ficar sabendo, a não ser que você autorize e o que aparecer no livro ou seja onde for, vai aparecer sem te identificar, ta certo!?.

Então F. eu queria te fazer umas perguntas, só que hoje alem da gravação eu preciso anotar umas coisas aqui. F. você nasceu aonde?

F: Belenzinho

$\mathrm{R}$ : Aqui em SP?

F: Isso.

R: Em que data?

F: 14 do 8 de 86 .

R: Você ta com!?

F: 17.

R: Vai fazer 18 em agosto desse ano né? F. como é o nome da sua mãe?

F: S.

R: S.. Sabe qual a idade dela?

F: 36

R: 36. Você tem irmãos F?

F: Tenho dois.

R: Dois irmãos.

F: Um de 18 e outra de 11.

R: Dos mesmos pais?

F: IsSo

R: E o seu pai está separado da sua mãe?

F: Ainda não mas minha mãe quer separar dele

R: Como é o nome do seu pai?

F: P.

R: P. Então eles estão casados. O teu irmão de 18, como é o nome dele? 
F: R.

R: Aí vem você com 17 e o de 8 é homem ou é mulher?

F: É homem..., não é mulher.

R: É mulher, e como é o nome?

$F: Y$.

R: E quantos anos o seu pai tem?

F: Parece que tem 35 agora, 35, 36.

R: Você se dá com seu pai?

F: Não, desde os meus 2 anos eu não vejo ele.

R: Ah eles estão separados...

F: Eles estão separados só que não se vêem. Eles não moram juntos.

R: Mas estão casados?

F: Tão casados ainda só que há 16 anos minha mãe não vê ele.

R: E a Y é filha dele?

F: Os 3 é filho dele.

R: Mas a Y. tem só 11.

F: Isso

R: Mas então ela encontra com ele.

F: Não a ultima vez foi há 11 anos atrás.

R: Ah..., foi há 11 anos atrás.

F: Aí não se viram mais.

R: Não se viram mais. E você lembra do seu pai?

F: Mais ou menos

R: Mais ou menos. Qual a razão da tua mãe não estar junto com ele, o que ela...

F: Meu pai bebia muito e batia em nós.

R: Você lembra de ter apanhado do teu pai?

F: Lembro, nós morava na rua ainda.

R: Vocês moraram na rua...! E depois que vocês se separaram do seu pai aí vocês saíram da rua? Como foi?

F: Saímos e fomos pra casa da minha avó.

R: Ah..., o teu pai que queria que vocês ficassem na rua? Quer dizer o teu pai não podia ir pra casa da tua avó?

F: Não, assim: minha avó não gostava do meu pai que ele bebia e batia em nós, aí minha mãe se separou dele e aí minha mãe foi morar com minha avó.

R: Ah..., entendi. A sua mãe faz o que F.?

F: Ela trabalha de...ajudante geral...

R: Ela mora lá junto com a sua avó.

F: Isso e meu tio. 
R: Ah..., tem um tio que mora lá também.

F: Também.

R: Como é o nome da sua avó?

F: I. G...(ininteligível)....

R: Oh loco sô...l. (risos).

F: G...

R: G..., deixe eu anotar isso aqui...É assim?

F: É.

R: Da onde é esse nome?

F: Russo.

R: Russo. I. G. de O.. Ela é russa?

F: Isso.

R: E qual a idade dela, você sabe?

F: Tem 59.

R: Cinqüenta e nove. Você conheceu o seu avô?

F: Conheci.

R: Ele é vivo?

F: Não, morreu.

$\mathrm{R}$ : Como era o nome do avô?

F: T. de O.

R: Faz tempo que ele morreu?

F: Quatro anos.

R: Se nós estamos em 2004 ..., ele morreu lá por 99.

F: Isso.

R: Do que ele morreu?

F: Ele tinha câncer.

R: E o seu tio é quem? É irmão da S. sua mãe?

F: É.

R: Como é o nome dele?

$\mathrm{F}: \mathrm{J}$.

R: Quantos anos ele tem?

F: Vinte e três.

R: E o que ele faz?

F: É carteiro.

R: Carteiro. Então, na casa da sua avó moram você, o teu irmão R., sua irmã Y. e o seu tio J. Mais alguém?

F: Minha avó e minha mãe. 
R: E a casa lá é grande? Pequena?

F: Tem 5 cômodos e um banheiro.

R: Então acomoda todo mundo.

F: Todo mundo.

R: E o seu irmão trabalha?

F: Não.

R: Não.

F: Tava trabalhando mas parou.

R: Tava trabalhando com o que?

F: Borracheiro.

R: Borracheiro. E ele estuda?

F: Estuda.

R: O que ele faz?

F: Ele ta no primeiro grau.

R: Primeiro grau.

F: Ele tava na minha frente mas eu passei.

R: Passou. Que ano vocês estão?

F: Primeiro.

R: De que série?

F: Colegial.

R: Ah então já estão no segundo grau..., é o primeiro ano do segundo grau!?

F: É.

R: Vocês dois passaram...., vocês estudaram juntos?

F: Não, assim, ele repetiu três anos e eu consegui alcançar ele e aí nós estamos na mesma sala.

R: Estavam na mesma sala desse ano que entra agora ou o ano passado?

F: O ano passado.

R: E agora esse ano que entra?

F: Agora eu vou estudar em outra escola que eu saí de casa.

R: Você não viu mais seu pai né?

F: Não.

R: E como é que é na sua casa lá?

F: É assim, toda vez que nós ta lá, na hora que acorda meu irmão já vem, já começa a brigar comigo, na hora do almoço é a mesma coisa, na janta e na hora de dormir já começa a brigar comigo. Aí minha mãe pensa que eu comecei a briga e começa a brigar comigo também, aí eu peguei e saí de casa. É briga direto lá.

R: Só com o teu irmão? 
F: Com meu irmão, com a minha irmã e com o meu tio.

R: Você também briga com a sua irmã e briga com o seu tio?

F: Sim.

R: E o teu irmão briga com a tua irmã e com o teu tio também?

F: É briga direto.

R: Todo mundo contra todo mundo.

F: É, então eu peguei e saí de casa.

$\mathrm{R}$ : E qual o motivo das brigas?

F: Bom é assim, eu pego uma roupa emprestada dele e ele já começa a pegar minha roupa sem pedir permissão e aí a briga começa, ou então ele pega a roupa do meu tio e aí começa a briga.

R: Vai usando sem permissão.

F: É.

R: E com a Y. por que a briga acontece?

F: Besteira, por causa de besteira.

R: Por exemplo.

F: Por que ela pega e troca de canal e ele vai e começa a brigar com ela.

R: E você briga com a Y. por que?

F: Não eu não brigo com ela, com o meu irmão e com o meu tio, só.

R: Com a Y. você se dá bem?

F: Com ela eu não brigo.

R: E o seu tio briga com a Y. também?

F: É só meu irmão que briga com ela.

R: Só teu irmão...E com a tua avó, como é a sua relação?

F: É mais ou menos.

R: Por que não é bom.

F: Porque no caso eu quero sair no final de semana, ela não deixa; eu quero sair pra curtir um baile com meus amigos ela não deixa, então eu só fico o dia inteiro lá na casa, e eu não posso sair.

R: Ela é dura?

F: Dura e minha mãe também.

R: Tua mãe também. E elas agem assim com o seu irmão também?

F: Não, meu irmão pode sair a hora que quiser.

R: E por que você acha que tem essa diferença?

F: Não sei. Talvez ela não goste de mim.

R: Você acha que elas talvez não gostem de você e ai te prendem em casa porque não querem que você se divirta..., é essa a sua idéia?

F: É. 
R: E com o seu tio? Ele saí a hora que ele quer?

F: Não por que ele trabalha de dia e só volta à noite, aí ele não sai. Ele só sai no final de semana.

R: Mas ele tem liberdade?

F: Tem, ele tem.

R: E você nem de fim de semana tem liberdade?

F: Não. Minha rotina é assim, limpar a casa, almoçar, ir pra escola, voltar e dormir.

R: Você já trabalhou?

F: Já.

R: Quando você morava lá com eles?

F: Já.

R: Você trabalhou com o que?

F: Pedreiro, borracheiro, também já trabalhei de padeiro.

R: Mas foram períodos pequenos.

F: Foram.

R: O que você ficou mais tempo durou quanto tempo?

F: Dois meses, foi de padeiro.

R: Dois meses, certo. O que você acha que a sua avó sente por você?

F: Sei que ela sente amor, mas ao mesmo tempo ódio.

R: Como você vê o amor que ela sente por você?

F: Ela fazendo carinho em mim.

R: E como você vê o ódio dela?

F: Ela me prendendo dentro de casa, não me deixando fazer nada.

R: Mas isso não pode ser um cuidado exagerado da parte dela?

F: Não porque onde que eu moro é calmo, não é perigoso.

R: Onde você mora?

F: Francisco Mourato, que é o bairro mais calmo de lá.

R: Sei... E o R., pra sair, discute com ela?

$\mathrm{F}$ : As vezes discute.

R: Com freqüência? Quase sempre?

F: Sim.

R: Ele sai mas é meio forçado. Não é fácil pra ele também.

F: É..Não às vezes numa boa. Quando minha avó..., ele fala que vai fumar maconha, essas coisas, aí minha avó discute com ele.

R: Por que ele fala isso pra sua avó?

F: Pra poder sair. 
R: Mas falar que vai fumar maconha é mesma coisa que provocar pra que ela não deixe.

F: É mas ele faz do mesmo jeito, ele faz qualquer coisa pra sair.

R: Você se sente injustiçado?

F: Sim.

R: E você quando pede pra sair pede pra ir aonde?

F: Jogar bola, ir curtir um baile, sair com os amigos.

R: Sei...Sua mãe é religiosa?

F: É.

R: De que religião?

F: Católica.

R: Ela costuma ir na igreja rezar?

F: No dia de domingo sim, de dia de semana não dá porque ela trabalha.

R: A sua avó também?

F: Todo mundo em casa.

R: Todos da casa..., mas igreja católica?

F: Isso.

R: Não é daqueles evangélicos?

F: Não.

R: Os evangélicos são mais rigorosos, né!? Conhece?

F: Já ouvi falar já.

R: Me conta como você resolveu sair de casa.

F: Não, eu já saí de casa desde os sete anos, ia e voltava.

R: Ah..., desde os sete anos.

F: Saía de casa, saía por um tempo e voltava, aí dessa ultima vez que eu saí eu falei que não ia mais voltar, então até hoje eu não voltei.

R: Eles sabem que você ta aqui?

F: Sabem.

R: Você parece estar com muita raiva...

F: Eu falei que pra lá eu não volto mais.

$\mathrm{R}$ : O que te dá mais raiva?

F: É ver que meu irmão pode fazer tudo, eu não posso fazer nada e ele ta ganhando nas minhas custas. Que ao mesmo tempo que eu sai de lá ...(ininteligível...) ... que eu não to mais lá.

R: Você deve estar furioso...E por que você escolheu sair de lá?

F: Porque não dava mais pra ficar lá.

R: E quando você saiu pra onde você foi?

F: Eu fui pro...(titubeante) ..., eu fui pra Sé e da Sé eu fui encaminhado pra cá. 
R: Você já conhecia a Sé?

F: Já.

R: As outras saídas você já tinha ido pra lá?

F: Já.

R: Quando tempo faz isso?

F: Que eu sai de casa da ultima vez?

R: É.

F: Vai fazer 3 meses e alguns dias.

R: E aí você foi pra Sé e ficou quanto tempo?

F: Fiquei um dia na Sé..., e aí eu vim pra cá pelo Travessia.

R: Você chegou na Sé e o pessoal do Travessia já....

F: Não eu dormi na Sé, aí no dia seguinte o pessoal do Travessia mandou eu pra cá.

R: O pessoal encostou em você e já te...

F: Não..., a tia já me conhecia já.

R: Ah ela já te conhecia.

F: Ela me conhecia e perguntou se eu queria vir pra cá, eu falei que queria então ela me trouxe pra cá, então eu to aqui.

R: Você já conhecia aqui?

F: Só uma vez que foi no..., é ... Operação Inverno que eu vim aqui, só que eu não dormi.

Eu vim aqui, comi, a tia me deu um cobertor e nós fomos pra rua de novo.

R: Quantas vezes você já saiu da sua casa?

F: Várias vezes

R: Você perdeu a conta?

F: Foi várias vezes.

R: Antes dessa vez agora, quando foi a ultima vez....

F: A ultima foi o ano retrasado.

R: Por que razão?

F: Foi pelo mesmo motivo, briga direto, meu irmão me batia, uma vez ele quase quebrou a minha perna, me jogou um tijolo desse tamanho..., eu peguei e saí.... Só que aí passou dois meses eu voltei, depois fiquei em casa e agora que eu saí.

R: E a primeira vez que você saiu como foi?

F: Primeira vez foi um moleque..., um colega me chamou pra sair, foi eu e ele pra Santos, aí nós ficamos um bom tempo lá depois nós voltamos pra casa.

R: Mas naquela época ..., você tinha 7 anos.

F: Tinha 7 anos.

R: Você era pequenininho, né! $\mathrm{E}$ o que deu de sair? Você tava com raiva também da situação da sua casa? 
F: Não sei.

R: O teu colega tinha quantos anos?

F: Tinha oito.

R: Oito! Como é que vocês foram pra Santos?

F: Cargueiro.

R: Cargueiro? Trem?

F: É trem cargueiro.

R: Ah..., subiram encima do trem e foram. E chegando lá como é que você se virou? Ficou

com medo?

F: Não.

R: Não!?

F: Que eu já morei lá em Santos, morava eu minha mãe e meu pai, nós morava

lá, depois nós viemos pra São Paulo e nós ficamos na rua.

R: Bom mas quando você morou lá quantos anos você tinha?

F: Tinha um ano e pouco.

R: Bom mas..., então porque você morou lá você não sentiu medo.

F: Não porque minha bisavó morava lá e eu sabia onde que era.

R: Ah..., então você foi pra tua bisavó!

F: Fui pra lá e depois eu sai de novo pra rua.

R: Você foi e levou o teu colega.... Tua bisavó caiu sentada quando te viu! (risos). Ficou apavorada. E quanto tempo você ficou lá?

F: Fiquei um mês e dois dias, aí nós pegamos e saímos e voltamos pra casa.

$\mathrm{R}$ : Como é que você vieram

F: Lá tem uma casa de acolhimento, daí eles traz pra São Paulo, encaminha pro Criança Cidadã e o Criança Cidadã encaminha pra casa.

R: Então quer dizer que essa foi a sua primeira aventura de fugir de casa, já é velho de guerra né (risos), tem experiência na estória... E foi bom ficar com a tua bisavó?

F: Foi.

R: Foi! Quem que morava lá?

F: Minha bisavó e meu bisavô.

R: Eles ficaram muito bravos com você?

F: Não

R: E por que você voltou pra São Paulo? Eles pediram pra você voltar?

F: Pediram.

R: Eles que pediram...., aí você voltou e quanto tempo você ficou sem fugir de novo?

F: Eu fugi depois de uma ano e pouco. 
R: Um ano e pouco.

F: Já tinha um ano e quatro meses.

R: E por que você fugiu?

F: Por causa do mesmo motivo, briga. Aí desde então, da primeira vez que eu fugi e que eu voltei, começou a briga e foi direto e desde então só tem briga dentro de casa.

R: Da primeira vez que você saiu você não sabe muito bem por que fugiu.

F: Não mas na segunda foi porque a briga começou desde os oito anos, desde lá é briga direto em casa.

R: E o seu tio..., você briga com seu tio também?

F: Poucas vezes mas brigo.

R: E por qual razão?

F: Por causa que ele tem um vídeo game e ele fica o dia inteiro no vídeo game e não deixa nós assistir.

R: Ah..., não deixa assistir a televisão.

F: É.

R: E a sua avó fica em casa o dia inteiro.

F: O dia inteiro.

R: E essas fugidas suas todas acabaram fazer você perder alguns anos de escola?

F: Não.

R: Não...você conseguiu..., o que você perdeu não foi por causa de...; você ta com 17, você devia estar no terceiro.

F: Não, no segundo.

R: No segundo, perdeu um ano.

F: Um ano por que a professora me reprovou, foi na primeira série.

R: Não foi por causa de falta, porque você fugia?

F: Não, porque eu tinha as presenças, foi por que eu não sabia mesmo e aí ela me reprovou, aí desde então..., foi só esse ano que eu repeti.

R: Como você se descreveria F.? Seu temperamento, seus defeitos e suas coisas boas...

F: Meu defeito é ficar bravo rápido.

R: Pavio curto.

F: Meu temperamento é mais ou menos, o comportamento é bom mas até quando não me tira do sério.

R: O problema é que você sai do sério fácil...

F: É, fácil, fácil...

R: É um problema pra você, né !?

F: Eu nessa casa já briguei com dois, com os dois nós saímos na porrada porque eles me tiraram do sério. 
R: Quer dizer, já passa pra agressão física... E como é que você está se sentindo aqui?

F: Aqui ta melhor do que em casa, aqui eu posso trabalhar, posso ter minha roupa, posso sair no final de semana.

R: Mas você não podia trabalhar estando em casa? Você podia...

F: Eu trabalhei só dessas três vezes.

R: Mas ninguém te proibia de trabalhar!

F: Não, essas três vezes não, a partir do momento que a escola caiu pra noite, elas não deixaram mais eu trabalhar.

R: Por que?

F: Porque falaram que ia ser muito corrido o meu dia, então elas não deixaram mais eu trabalhar.

R: E você quer trabalhar!

F: Quero trabalhar.

R: O que significa trabalhar pra você?

F: Bom, pelo menos eu posso ter as minhas coisas e não depender da minha mãe e da minha avó.

R: Sua mãe e sua avó não tem muitos recursos pra ficar te dando coisas....

F: Não....

R: E você ..., como é que você pensa em fazer daqui pra frente?

F: Arrumar o meu dinheiro, comprar a minha casa, reunir minha família, trabalhando honestamente.

R: Bom mas vamos dizer assim, mais curto (risos), daqui pra frente é esse ano, o que você pretende fazer?

F: Bom eu quero entrar num dinheiro pra comprar pelo menos o meu barraco pra eu ficar e terminar a escola e continuar trabalhando.

R: Você tem um trabalho nesse momento?

F: Tem um trabalho, começo dia 5, vou trabalhar de Office-boy.

R: Você teve alguns trabalhos agora recentemente...

F: Tive.

R: Parece que você teve um problema ou outro.

F: Foi.

R: Você também não conseguiu se conter?

F. Não e aí eu saí do trabalho e...., mas antes de sair desse trabalho eu já tinha conseguido outro.

R: Quais foram os problemas?

F: Bem, primeira vez que eu fui trabalhar, sumiu 50 contos, a mulher deixou quieto, agora essa ultima vez sumiu 10 contos de novo, ela veio me acusar e os 50 contos que tinha sumido eu paguei do meu salário, os 10 contos eu também paguei, ela veio falar que eu roubei, então eu peguei e saí. 
R: Bom, roubar muita gente rouba, muita gente já fez isso; as vezes você ta precisando, você ta querendo, ta sem grana. O problema é quando você rouba sempre, quando você rouba muito, quando você rouba de quem não tem, isso é um problema porque as pessoas vão atrás de você, ninguém gosta e você acaba prejudicando a própria vida, esse é o grande problema, ninguém quer você por perto, mas as vezes a pessoa..., pequenos furtos isso é passageiro, é uma coisa que muita gente faz na adolescência. Você acha que o roubo é um problema pra você?

F: Não porque eu não roubo...

R: De vez em quando só...!!!

F: risos...

R: Aqui entre nós, não precisa ficar envergonhado...

F: Assim, eu roubo uma vez ou outra, não é direto, assim todo dia, toda hora, é uma vez ou

outra. Por que já teve uma época que me chamaram pra roubar no farol, eu falei não! Eu não sou muito de roubar.

R: A gente entra num mercado... enfia um negócio no bolso...

F: É (risos).

R: E agora você vai trabalhar de Office-boy.

F: Vou.

R: E namorada? Espera um pouquinho só deixe eu virar a fita. Pronto e aí como é a história com as namoradas?

F: (Risos). Bem essa ultima agora!? Ou desde a primeira?

R: De uma maneira geral assim. Você já teve muita namorada?

F: Já.

R: Você se dá bem com elas ou não se dá bem com elas, briga muito? Como é?

F: Eu me dou bem..., nós briga de vez em quando e o resto é tudo normal.

R: Você é muito namorador?

F: (risos)

R: É?

F: Até agora eu estou procurando a minha namorada e ainda não encontrei, porque ela estava no Criança Cidadã, eu fui lá e ela saiu de lá, agora eu não sei aonde que ela ta.

R: Ah..., tem uma especial?

F: Tem.

R: Ah...., quem é ela?

F: Priscila, essa daí foi a última e eu to atrás dela até hoje.

R: Ela ficou marcada.

F: Ficou.

$\mathrm{R}$ : O que foi de bom?

F: Tudo..., desde o dia que eu conheci ela foi tudo maravilhoso. 
R: É! Por exemplo..., dá um exemplo.

F: Como assim?

R: Ah .., o que foi legal, o que mudou, o que você gostou muito..., o que foi significativo pra você.., o que as outras não tinham...

F: O beijo dela.

R: O beijo..., quanto tempo vocês ficaram juntos?

F: Nós estava há 3 meses já.

R: Três meses..., vocês moraram juntos? Vocês ficaram juntos na rua?

F: Ficamos juntos na rua.

R: E por que vocês se separaram?

F: Então..., ela foi pro abrigo e eu fui pra casa, de casa eu vim pra esse abrigo, aí nós se separamos, aí desde então eu não vejo mais ela.

R: Faz quanto tempo?

F: Agora vai fazer 3 meses também que eu não vejo ela também....

R: Você teve noticia dela?

F: Bom, a Pámela que ta aqui embaixo, falou que ela...., eu tive noticia dela pela Pámela, que ela tava no Criança Cidadã, essa foi a ultima noticia que eu tive dela.

R: Ta com saudade!?

F: To.

R: Depois dela teve outras?

F: Tem uma aí só que eu to enrolado.

$\mathrm{R}$ : Como é enrolado?

F: Fica, não fica.

R: É só pra passar o tempo?

F: Não, pra namorar mesmo só que ela ta indecisa.

R: Ah..., ela ta indecisa. Como é que você se sente quando você ta namorando?

F: O homem mais feliz do mundo!

R: É !, faz bem pra você.

F: Faz.

R: Quando você ta sozinho é pior.

F: É, fica uma solidão.

R: E aqui com as meninas daqui você também paquera com a mulherada daqui?

F: Não.

R: Não! Por que? Por que não gosta? Ou por que não foi com a cara de nenhuma.

F: Não, por que não gosto. Porque não vira. Aqui é só no leve mesmo.

R: Dá problema? 
F: Dá.

R: É..., que problema?

F: Elas tem namorado na rua e elas fala que não tem, aqui dentro, chega lá fora os cara chama nós de Talarico.

R: O quer dizer Talarico?

F: Quem namora a mulher dos outros.

R: Ah..., e aí sai no pau...

F: Sai no pau.....

R: E me fala uma coisa, como é que é a história de droga pra você? Você gosta, não gosta,

já usou muito?

F: Não..., eu só usei umas três vezes.

R: Ah é..., você não gosta?

F: Não.

R: Qual você experimentou?

F: Maconha.

R: Cola, essas coisas você não...

F: Não..., só que a maconha....

R: Não foi muito legal pra você...

F: Não..

R: O que você sentiu?

F: Não teve graça, aí só usei três vezes e parei, até hoje estou sem usar...

R: É bom, é sorte que você tem, né... E o pessoal? Eles não zoam você por causa disso?

F: Não.

R: Te respeitam? Eu pensei que o cara que não usasse, no meio, aí os cara...

F: Não, porque usa quem quer, porque é minha decisão, eles tem a decisão deles, eu tenho a minha.

R: É eu entendo...

F: Aí eles respeitam minha decisão lá fora...

R: Eu não sabia que eles respeitavam.

F: Eles respeitam.

R: Respeitam! Legal..., eles não devem te forçar nem a roubar, nem a nada.

F: Não..., me chamaram tantas vezes pra roubar e eu falei que não.

R: E com o pessoal daqui, o que vocês gostam de fazer?

F: Nós saímos pra jogar bola.

R: Jogar bola...

F: Jogar bola, sair pro baile, amanhã vai eu e o D., amanhã....pro Tio Sam. 
R: O que é o Tio Sam?

F: É salão de Hip-Hop.

R: Aqui perto?

F: Em Santana, perto de Santana, nós vai lá....

R: Muita gatinha..

F: É.

R: E me fala um pouco, quando você era mais criança, como era a relação com o teu irmão?

F: Foi briga sempre..

R: Sempre...E tem mais gente da tua família assim..., outros tios, primos...

F: Tem vários tios, primos....

$\mathrm{R}$ : $\mathrm{E}$ todos vocês se vêem?

F: Todos, de vez em quando nós se vê, nós vai na casa dos tios e dos primos...

R: Você teve alguma doença F.?

$\mathrm{F}$ : Tive quando era pequeno.

R: O que você teve?

F: Hérnia...., tive dos dois lados, eu operei.

R: Só... e o teu irmão e a tua irmã, alguma doença?

F: Minha irmã já teve tuberculose, meu irmão que eu me lembro não, nem minha mãe.

R: E a tua avó?

F: Não, só meu avô que teve um câncer.

R: Você gostava do seu avô?

F: Muito.

$\mathrm{R}$ : O que você sentiu quando ele morreu?

F: Perda....

R: O que você acha que seu avô sentia por você?

$\mathrm{F}$ : Ele tinha muito carinho por mim.

R: Tinha! Você acha que mais que a sua avó?

F: Sim.

R: Mais que a sua mãe?

F: Sim.

R: Foi uma perda pesada. Bom F. eu não quero ficar falando muito dessas coisas no

primeiro dia porque você fica lembrando né?; vamos devagar então. F. a gente pode

continuar outro dia? Amanhã você vai estar aí?

F: Domingo eu to aqui. 
R: Então vamos parar por hoje, domingo a gente continua. Obrigado por hoje.

\section{Segunda entrevista:}

R: Você ta acordando agora (risos), mas vamos continuar a entrevista de ontem. F. uma coisa que eu não perguntei pra você é como foram as suas amizades? Você teve amigos? Teve algum importante? Você não teve? Você se dava bem com as pessoas? Conta um pouco sobre isso.

F: Sempre tive amigos na vida, mas só teve um que era importante, ainda é importante porque é onde que eu moro, ele mora lá também, toda vez que eu vou pra minha casa eu vou lá ver ele.

$\mathrm{R}$ : Ah é..., como é o nome dele?

F: N.

R: N.!?

F: É. C. só que o apelido dele é N.

R: Que idade ele tem?

F: Já tem 18.

R: Dezoito... E o que vocês aprontavam juntos na vida assim que foi legal?

F: Ah..., muitas coisas, por exemplo jogar bola na chuva, pegar rabeira.

R: De caminhão?

F: É, muitas coisas nós fizemos na vida, ele foi o mais importante da minha vida.

R: E o que você diria que foi muito importante pra você na tua amizade com ele? O que foi especial, que não tinha com os outros?

F: Ah..., nunca teve briga com ele.

R: Não..., por que você acha que nunca teve briga com ele?

F: A gente sempre se dava bem.

R: Sei, você sabe distinguir alguma qualidade especial nele que te deixa mais tranqüilo?

F: Ele é calmo.

R: Calmo..., você já é o esquentado.

F: É...

R: Você nunca teve vontade de brigar com ele?

F: Não....

R: Não.

F: Ele também nunca me provocou pra brigar.

R: É..., quantos anos de amizade vocês tem?

F: Já faz 10 anos.

R: E como ele se comporta, o que ele fala quando você sai de casa?

F: Ah..., ele fala pra eu voltar, que eu to errado. 
R: Como é a cabeça dele, desse cara?

F: É feita.

R: Em que sentido?

F: Bom ele nunca usou uma droga, nunca aprontou nada na vida e ta trabalhando.

R: Ele faz o que?

F: Ele entrega pizza.

R: Ele tem família?

F: Tem.

R: Como é a família dele?

F: É legal a família dele, tem a mãe dele, tem a irmã dele e tem a prima dele, eles moram na mesma casa.

R: Ele não tem pai?

F: Não.

R: E ele se dá bem com a família?

F: Dá.

R: Ele estuda?

F: Estuda, ele ta no terceiro já.

$\mathrm{R}$ : E ele pretende fazer alguma coisa?

F: Faculdade.

R: Do que?

F: Medicina.

R: Oh loco..., é um objetivo alto né, difícil de concretizar. Você tem algum sonho nesse sentido?

F: Bom se eu não conseguir ser jogador de futebol, eu vou fazer medicina também.

R: É..., mas você gosta de estudar? ...gosta? Você imagina o esforço que você tem de fazer para se formar em medicina?

F: Já me falaram

R: É.... Não tem sábado nem domingo, não tem namoro, é só ali..., você já sabe disso?

F: Já.

R: E por que você gostaria de fazer medicina?

F: Ajudar os outros.

$\mathrm{R}$ : E que especialidade da medicina?

F: Enfermagem.

R: Enfermagem não é medicina, é um outro curso, mais fácil de fazer do que a medicina. Médico ele receita, ele opera, o enfermeiro ele ajuda nos curativos, na aplicação da injeção, no acompanhamento do paciente, ele ajuda nessas coisas, são dois cursos diferentes. Especialidade da medicina é: cardiologia que trata do 
coração; gastro que trata da barriga; ortopedia que trata dos ossos quando quebra; psiquiatria que trata da cabeça, é assim. E me diga uma coisa $F$., no meio desse ano você completa 18 anos, você sabe que tem restrições nas casas quando as pessoas chegam aos 18; como é que você encara isso?

F: Normal porque eu já alugo uma casa também, eu já tenho onde alugar já.

R: Tem...., aonde?

F: Ali na Baixada do Glicério, da tia da $M$.

R: Quem é M?

F: Colega minha.

R: E é barato? Dá pra você pagar?

F: Dá..., que vai três pra lá.

R: Quem vai?

F: Eu, o A. e o E.

R: São daqui?

F: São daqui.

R: Eles trabalham?

F: O A. sim, o E. ta vendo se arruma emprego.

R: Sei... E da tua mãe, fala um pouco da tua mãe.

F: Da minha mãe? Eu não sei o que falar.

R: O que você quiser falar. O que você sente, o que te faz falta, o que é bom....

F: O que eu queria é o carinho da minha mãe, ela nunca fez carinho.

R: Por que você acha que ela nunca fez carinho em você?

F: Nunca vi ela fazer um carinho, desde criança.

$\mathrm{R}$ : Mas você imagina que tem algum motivo?

F: Não....

R: Será que a tua mãe recebeu carinho?

F: Recebeu com certeza.

R: Com certeza!? Por que você acha isso?

F: Porque ela sempre falava.

R: O que ela falava?

F: Minha avó sempre deu carinho pra ela.

R: E a tua avó deu carinho pra você?

F: Ela deu.

R: A tua mãe trabalha bastante, né.

F: É.

R: Ela é nervosa? Como é o temperamento da tua mãe, conta um pouco.

F: Nervosa.

R: Como é assim? 
F: Quando a gente faz alguma coisa ela fica brava.

R: Isso te magoa, né? E como era com o teu avô?

F: Com o meu avô era sempre um carinho, ele foi o primeiro pai pra mim.

R: Brincava com você?

F: Brincava.

R: Com o teu irmão também? E o que ele fazia quando vocês dois brigavam?

F: Ele ia lá e conversava com nós.

R: Que exemplo que o teu avô te deixou assim? Se ele deixou algum pra você!

F: Ser honesto na vida.

R: E a tua mãe?

F: Ah..., ela não deixou nada pra mim não.

R: E a tua avó?

F: Nunca maltratar ninguém, principalmente velho.

\section{Entrevista dirigida:}

R: Vou te fazer umas perguntas agora: qual a melhor coisa que já te aconteceu?

F: Conhecer a P.

R: Conhecer a P., aquela namorada que você está procurando. Ela é importante mesmo pra você. E você está fazendo força pra encontra-la?

F: To

R: Tá! O que você fez ultimamente?

F: O vou perguntar em todos os lugares em que ela fica.

R: E a notícia que deram, a última era que ela tava aonde?

F: No Criança Cidadã.

R: E você já foi lá?

F: Já.

R: Mas não achou?

F: Não.

R: O que disseram?

F: Falaram que ela não estava mais lá, que ela saiu.

R: Pra rua ou pra casa?

F: Pra rua.

R: Pra rua...., e você não sabe onde ela pára?

F: Não..., que ela vai em vários lugares.

R: Você acha que ela gostaria de te encontrar também?

F: Certeza que sim. 
R: Com certeza!? É bom você ir deixando recado por aí né, avisando que você tá aqui.

R: Qual foi a pior coisa que te aconteceu?

F: Ter brigado com a minha mãe

R: Ter brigado com a tua mãe. Mas teve uma briga em especial, ou são todas as brigas?

F: Todas.

R: Você preferia ter uma relação boa com ela.

F: Preferia

R: Você tá muito magoado, né F.? ...Qual a melhor coisa que poderia te acontecer?

F: Arrumar um emprego melhor.

$\mathrm{R}$ : $\mathrm{E}$ o que seria um emprego melhor?

F: Ah..., carteira assinada...., essa coisa toda.

R: Por que o emprego que você vai começar trabalhar não....

F: Não só depois que eu servir o exército.

R: Ah..., não vai dar mais certo? Você não ia começar dia 4?

F: Vai, eu começo depois de amanhã, mas aí não vai registrar.

R: E o que você acha de servir o exército?

$\mathrm{F}$ : Ah ... eu não quero servir não.

R: Não, é jogo duro.

F: É.

R: Pagar flexão, abdominal, lavar banheiro, não é mole não. ....E qual é a pior coisa que poderia te acontecer?

F: Morrer.

R: Você morrer? Você gosta de viver?

F: Eu adoro.

R: Mesmo com todas as dificuldades e mágoas e ressentimentos do teu irmão? Mesmo assim tem prazer de viver?

F: Sim.

R: Você sabe como é a estória do gênio da lâmpada?

F: Sei.

R: Se você encontrasse um gênio que pedidos você faria? Quais os 3 pedidos que você faria?

F: Primeiro encontrar a P.; segundo me reconciliar com minha família; e terceiro que

eu tivesse uma vida melhor.

R: Como é uma vida melhor? 
F: Tendo minha família em paz, eu poder arrumar uma casa pra mim e uma pra minha família.

R: A casa que a tua família vive não é boa?

F: Não, não é nossa.

R: Ah, é alugada! F. você sabe o que é uma ilha?

F: Sei.

R: Se você tivesse que morar numa ilha quem que você levaria?

F: Você já sabe (risos).

R: A Priscila (risos). E mais alguém?

F: Não.

R: Não, só ela. E quem você não levaria de jeito nenhum?

F: Minha família.

R: Tua família, todo mundo, sem exceção?

F: Sem exceção.

R: Se você estivesse fazendo uma viagem de navio, e o navio começasse a afundar e tava a tua família lá, o que você fazia?

F: Salvaria.

R: Quem você salvaria?

F: Minha avó.

R: Sua avó, a única pessoa, também não dá pra salvar mais. Se você ganhasse na loteria, muita grana, como você gastaria o dinheiro?

F: Compraria uma casa pra minha família, os objetos da casa e colocaria o resto no Banco.

R: Guardaria pra que?

F: Pra usar mais tarde..., comprar um negócio pra mim.

R: Você costuma sonhar muito?

F: Sim.

R: Sonhos bons ou ruins?

F: Sonhos bons e ruins.

R: Você pode contar um bom e um ruim que você costuma sonhar?

F: Bom? Eu sonhei com a minha família, que eu tava em paz com ela e ruim, que eu tava brigando com ela.

R: Você costuma sonhar muito com isso?

F: Sim.

R: Como você imagina que vai ser sua vida quando você for adulto?

F: Ah...., eu espero que seja a melhor possível.

R: Aonde você pensa em morar? Você pensa em casar? Pensa em ter filho? Você pensa em morar na praia? Não casar e ser namorador? O que você pensa? 
F: Ah..., eu penso numa casa por aqui mesmo, não quero ir pra praia não, casar até que pode ser, ter filho só uns dois só, um homem e uma mulher.

R: Um casal. Você sabe como é gerada uma criança?

F: Sei.

R: Sabe..., a relação sexual, o espermatozóide o óvulo, tudo isso você sabe? Onde se forma a criança?

F: Na barriga.

R: No útero

F: Isso.

R: E quando você tem sexo, como você se sente?; fica a vontade?; envergonhado?

F: À vontade

R: À vontade. Você não tem constrangimento

F: Não

R: Ta bom F., você quer dizer alguma coisa? Então posso voltar amanhã? Tchau!

\section{HTP e desenhos livres}

R: Então F. hoje é dia 4 de janeiro de 2004, e hoje nós vamos ter mais uma conversa pra ver se a gente consegue acabar hoje com a parte principal das entrevistas, certo? Hoje nós vamos fazer um negócio diferente, você tem aqui papel, lápis, borracha, lápis colorido, giz de cera, então eu queria que você desenhasse aqui nessa folha, uma coisa qualquer, o que vier na sua cabeça, sem se preocupar..., eu não estou avaliando se você sabe desenhar ou não, entendeu, é só pra ter um motivo de você se expressar, pra mostrar assim a tua imaginação, a tua fantasia...., o que você quiser, pode usar aí lápis preto, borracha, giz de cor, use o que você precisar.

R: Me conta uma estória sobre essa casa, as pessoas que moram lá dentro, quem não mora, quem foi embora, quem chegou, como é o clima.

F: É onde que eu morava.

R: Como?

F: É onde que eu tava morando.

R: Essa casa é...

F: É onde que eu tava, mora minha mãe, minha avó, meu tio, meu irmão, minha irmã...., eu morava aí também, desde o dia em que a gente mudamos pra essa casa..., eu tinha sete anos. Toda vez que a gente ia conversar saía briga, desde os sete anos pra cá, isso há 10 anos atrás, ...(ininteligível)..., daí eu saí dessa casa.

R: E quem é essa pessoa aqui ao lado da casa?

F: É eu.

R: Com quantos anos?

F: Aí eu tinha 16. 
R: Como você estava se sentindo nesse momento?

F: Mal, aí era direto briga, chegou uma hora que eu tive que sair dessa casa.

R: E essa arvore?

F: É uma arvore que tinha lá, eu gostava de subir lá.

R: É arvore de fruta?

F: É

R: De qual?

F: Maçã.

R: E ela dava fruta?

F: Dava.

R: E a casa de verdade é parecida com essa?

F: É.

R: Lá tem um quintal assim grande?

F: Tem.

$\mathrm{R}$ : Aonde você falou que era?

F: Francisco Mourato.

R: Qual vai ser o futuro dessa casa?

F: Não sei.

R: F. me faz agora uma árvore.

R: Eu preferia que você não fizesse palmeira, uma outra arvore.

R: Que arvore é essa?

F: Uma arvore comum

R: É....comum..., ela é de fruta ou não é?

F: Não.

R: Não..., na sua imaginação onde ela estaria situada?

F: Numa montanha alta.

R: Numa montanha alta..., ela está embaixo da montanha, no alto?

F: No alto.

R: No alto da montanha. Vão pessoas nessa montanha?

F: Não

R: Ela é uma arvore meio isolada

F: Isso

R: Ninguém vai lá nesse lugar ou vai pouca gente?

F: Vai muito pouco.

R: Muito pouca gente. Quantos anos essa arvore tem?

F: Vinte.

R: Vinte anos. Quem habita essa arvore? 
F: Os passarinhos.

R: Ela ta bem de saúde?

$\mathrm{F}$ : Mais ou menos

R: O que ela tem?

F: Ela ta apodrecendo.

R: Ta apodrecendo..... Por que?

F: Ninguém cuida dela.

R: Ela sozinha, não está conseguindo se cuidar.

F: Não.

R: Há outras arvores por perto?

F: Não.

R: Ela é a única da montanha?

F: A única que sobreviveu.

R: Sobreviveu ao que?

F: Às tempestades

R: Tempestades de que?

F: Chuva e granizo.

R: O que falta pra essa arvore?

F: Ser bem cuidada.

R: Quanto tempo você acha que ela tem ainda de vida?

F: Um ano, um ano e meio.

R: Você acha que ela teria recuperação?

F: Sim.

R: Com cuidados ela teria recuperação?

F: Sim

R: Quer dizer mais alguma coisa dela?

F: Não.

R: Agora eu queria que você me desenhasse uma outra casa, que não fosse a tua, uma casa da tua fantasia. A primeira que você fez foi quase um desabafo, essa casa nesse momento da sua vida está assim um negócio mal digerido aqui dentro, acho que você a desenhou pra desabafar. Agora eu queria que você me desenhasse uma outra, da tua fantasia.

R: Me fala um pouco dessa casa...., to vendo uma porção de janelas, é uma casa grande?

F: É.

R: Quantas pessoas moram aí, e quem que mora aí?

F: Eu, minha mulher e meus filhos.

R: Ah... ôrra (risos), quantos filhos tem aí? 
F: Três.

R: Ah..., tem muito quarto né. Essas janelas é tudo de quarto?

F: Não.

R: É o que?

F: Cozinha, sala de jantar, sala de visita, três quartos é dos meus filhos, quarto pra visita e o quarto meu e da minha mulher.

R: Como são seus filhos? Falo idade, sexo...

F: Um menino e uma menina...., dois meninos e uma menina.

R: Que idade?

F: Um tem um ano e meio o outro tem três e o outro tem seis.

$\mathrm{R}$ : A menina é a do meio?

F: Isso

R: E qual o nome da tua mulher? (risos) ...fala....

F: (risos) P.

R: E o nome do teus filhos?

F: Yasmim, Roberto e Carlos.

R: E qual é o dia a dia nessa casa?

F: Eu saio cedo pra trabalhar e minha esposa fica cuidando dos meus filhos.

R: Eles estudam?

$\mathrm{F}: \ldots$.....

R: E como é quando você volta? Que horas você volta? Que você faz?

F: Sete horas eu to voltando.

R: E o que você faz?

F: Primeiro vou jantar. Depois janto e vou pra sala de televisão ficar assistindo.

R: Quem que vai?

$\mathrm{F}$ : Eu, os meninos, depois 10 e pouco nós coloca eles pra dormir, depois nós também vai dormir.

R: E você trabalha com o que?

F: Empresário.

R: De que ramo? O que você faz?

F: Carros.

R: O que você faz? Você vende carros? Você tem mecânica?

F: Vendo carros.

R: Vende carros. E costuma ir gente visitar aí, nesse quarto de visita, costuma ser ocupado? Por quem?

F: Meus tios.

R: Seus tios...; quem são os seus tios?

F: São meus tios que vivem em outras casas. 
R: Ah...ta certo. E essa fumaça aí na chaminé, o que está acontecendo aí?

F: Uma fogueira.

R: Ah..., você faz fogueira dentro de casa?

F: É pra esquentar.

R: Ah...., é pra esquentar a casa...., não é de cozinha não.

F: Não.

R: Ah..., ta certo. O que falta nessa casa?

F: Como assim?

R: O que você achar...., o que vier na tua imaginação que faltaria nessa casa; tanto do ponto de vista material como nas pessoas. Que pessoas ficariam legais aí? Que pessoas você traria?

F: Minha avó, minha irmã.

R: Sua avó e sua irmã. E o que tem de bom nessa casa?

F: Tudo.

R: Tudo. Aonde ela está localizada?

F: Perto da praia.

R: Perto da praia. Por que perto da praia?

F: É um lugar bom.

R: O que é bom? O que traz de bom?

F: Dá pra sair pra caminhar com as crianças...

R. Certo..., quer falar mais alguma coisa dela? F. me desenha uma pessoa.

R: Quem é essa pessoa?

F: Meu irmão.

R: Seu irmão? Como é o nome?

F: R.

R: Quantos anos ele tem aí?

F: Dezoito.

R: Dezoito. O que é essa expressão dele? fala um pouco...

F: De malvado.

R: Malvado. O que passa na cabeça dele?

F: Muita maldade.

R: Ele tem alguma coisa de bom?

F: Não

R: Por que ele é assim?

F: Não sei

R: Você acha que ele pode mudar?

F: Talvez.

$\mathrm{R}$ : Depende do que? 
F: Dele.

R: Quer falar alguma coisa a mais?

F: Não.

R: Então me desenha uma pessoa do sexo oposto.

R: Quem é essa pessoa?

F: Minha irmã.

R: Como é o nome?

F: Y.

R: Quantos anos ela tem?

F: Onze.

R: O que é essa expressão dela?

F: Ela ta esperando pra me dar um abraço.

R: E ela ta...., qual é o sentimento dentro dela?

F: Felicidade.

R: Com o que ela sonha?

F: Que eu volte pra casa.

R: Você acha que ela tem saudades de você. Sua casa tem telefone?

F. Não.

R: Você nunca mais voltou pra lá?

F: Já.

R: Já. Você sente falta dela?

F: Sinto.

R: Do carinho dela?

F: Sim.

R: Quem te dá mais carinho na sua casa?

F: Ela, minha irmã e minha avó.

R: Ela...

F: E minha avó.

R: Vocês brincavam muito? Do que era a brincadeira?

F: Pega-pega.

$\mathrm{R}$ : O que falta pra ela $\mathrm{F}$ ?

F: Eu.

$\mathrm{R}$ : E o que ela tem de bom?

F: O amor dentro dela.

R: Ela ta saudável?

F: Tá.

R: Como vai ser a vida dela? 
F: A melhor possível.

R: Quer falar mais alguma coisa dela?

F: Não.

R: Então eu vou te pedir um ultimo desenho. Me desenhe novamente um desenho livre, qualquer coisa, o que você quiser.

$\mathrm{R}$ : O que representa esse desenho?

F: Um desenho de paz.

$\mathrm{R}$ : De quem é esse coração?

F: De toda a minha família

R: E esse laço?

F: A união de todos.

R: O que falta pra isso acontecer?

F: Ter muita paz na minha casa.

R: E você..., o que você poderia fazer a esse respeito? O que você acha que depende de você?

F: De mim não, do meu irmão, depende dele, que é ele que começa a desunião na minha casa.

R: Você quer dizer mais alguma coisa?. Não!? 


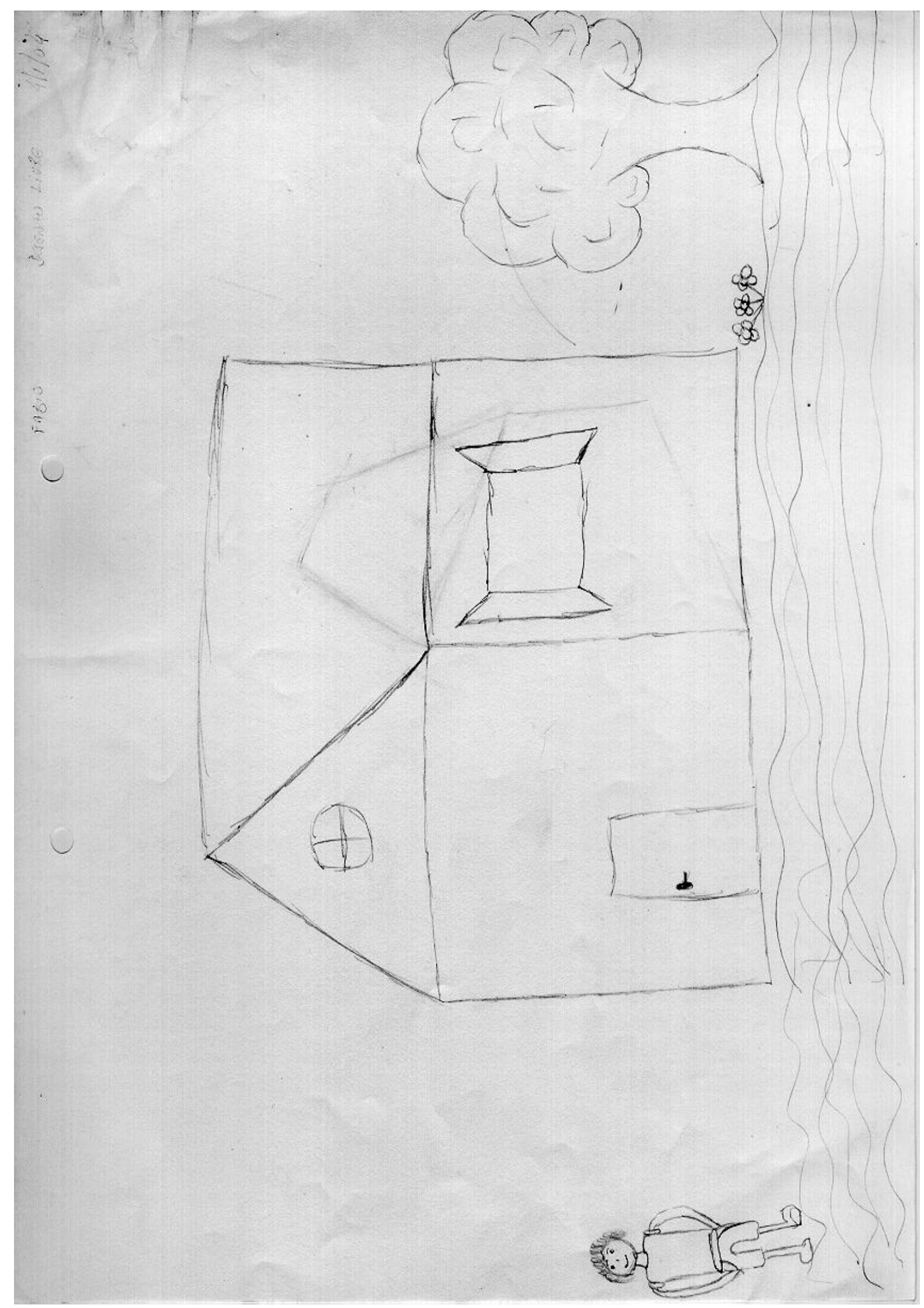





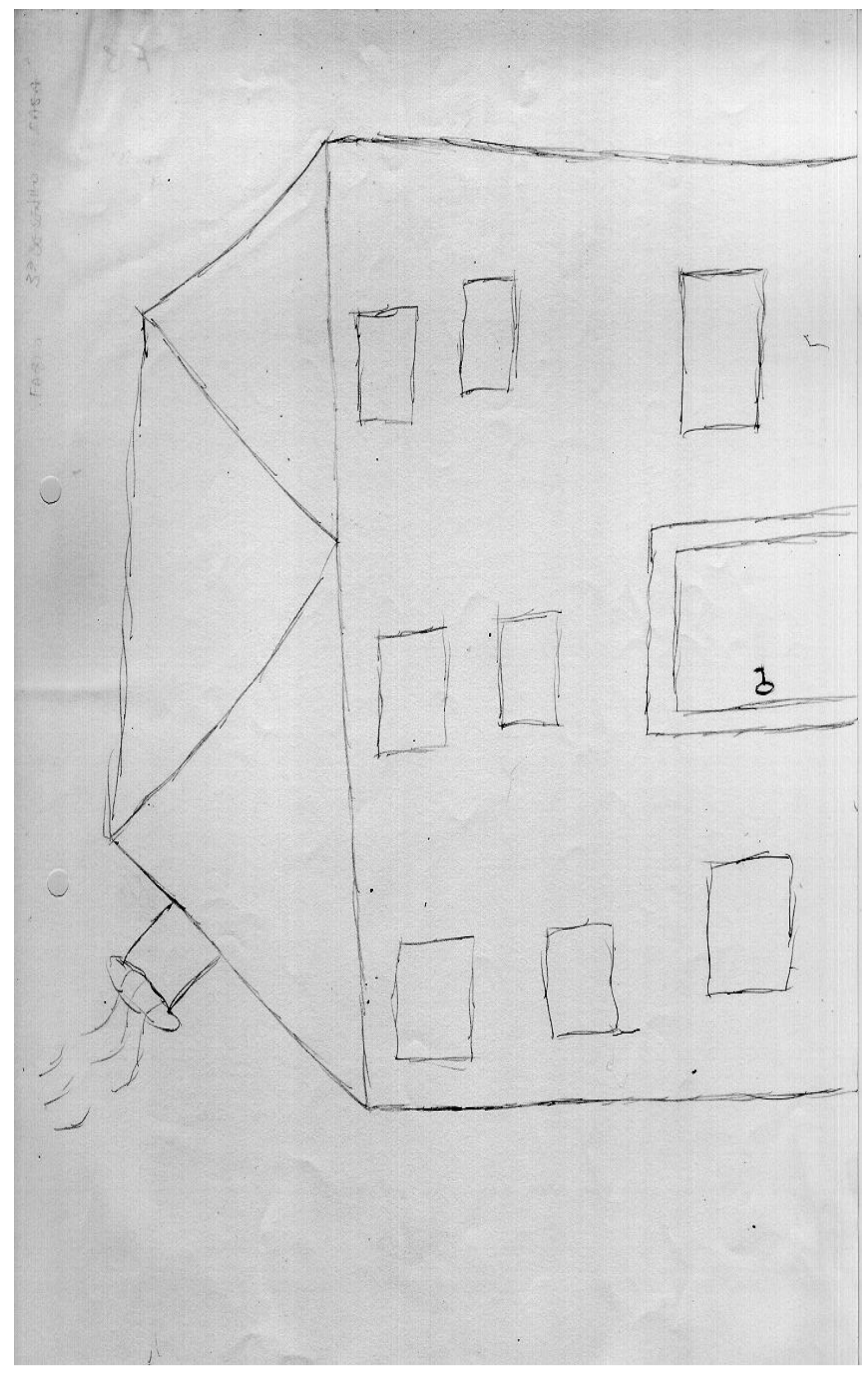




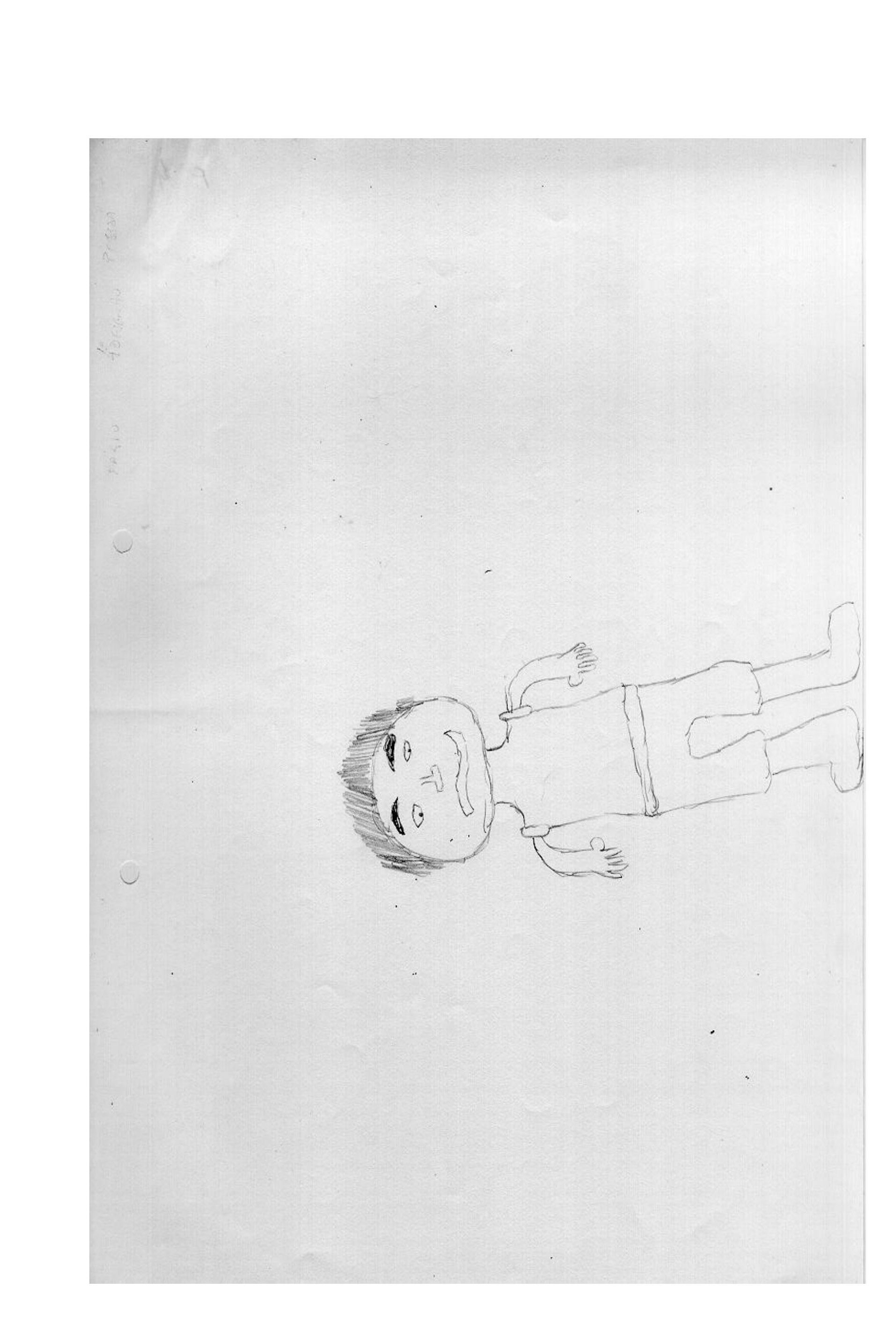






\section{TAT}

R: Bom vamos para uma outra atividade: eu vou te mostrar umas figuras e eu queria que você me contasse uma estória da sua imaginação, a respeito de cada uma das figuras, sem se preocupar com realidade, ou com bom senso, ou se é certo ou se é errado. Bom aqui, o desenho da prancha 1, o que você vê aqui?

F: Um garoto olhando um violino.

R: E o que está acontecendo, o que ele está pensando?

F: Ta tentando apreender como se toca.

R: E qual é o sentimento dele?

F: (não responde)

R: Não sabe?

F: Não

R: O que aconteceu antes de chegar aí? O que houve um pouco antes de chegar esse momento?

F: Ele andou

R: O que?

F: Andou...

R: Andou.... Esse violino já era dele? Ganhou? Ele achou, ou é de outra pessoa?

F: É do pai.

R: O violino é do pai!? O pai emprestou? Ele está mexendo nas coisas do pai?

F: Ele deu de presente pra ele.

R: Deu de presente. E como vai ser o futuro disso, a seqüência?

F: Ele vai aprender a tocar.

R: Ele vai aprender.....Então ta ótimo.

R: Vamos pra outra agora, prancha 3 MF. O que você vê nessa? O que tem nessa estória? Conta uma estória em cima dessa imagem.

F: A mulher brigou com o marido dela, abriu a porta e saiu chorando.

R: Essa porta é da casa dela?

F: É

R: E qual a razão da briga com o marido?

F: Bebida.

R: Quem que bebe?

F: O marido dela.

$\mathrm{R}$ : E o que ele faz quando bebe?

F: Bate nela.

R: E o que vai acontecer daí pra frente?

F: Ela vai se separar dele. 
R: Ela está indo pra onde agora?

F: Pra casa da irmã.

R: Vai terminar que eles vão se separar.

F: Isso.

R: Mais alguma coisa?

F: Não.

R: Prancha 7 RH. O que tem aí nessa figura?

F: O pai e o filho.

R: O que eles estão fazendo?. O que eles estão conversando?

F: Os dois estão conversando.

$\mathrm{R}$ : A respeito do que?

F: Arrumar serviço pro filho dele.

R: Qual o estado de espírito do pai?

F: Calmo.

R: E do filho?

F: Ah..., um pouco preocupado.

R: Com o que?

F: Se o pai dele vai conseguir arrumar emprego pra ele.

R: Ah o pai é que deveria arrumar emprego pra ele.

F: É.

R: E o pai está tranqüilo em relação a isso?

F: Tá.

R: E esse filho é trabalhador, é esforçado ou não?

F: É.

R: E com vai se desenvolver essa estória?

F: Ah..., ele arruma o emprego.

$\mathrm{R}$ : E que emprego que seria?

F: Contabilidade.

R: E qual o sentimento entre os dois aí?

F: Carinho

R: Mais alguma coisa? Prancha 8 RM. O que você vê nesse desenho?

F: Uma pessoa sendo morta

R: Quem é essa pessoa?

F: Uma mulher.

R: Qual a razão desse ataque a ela?

F: Assalto.

R: Assalto. E ela é muito rica? Por que estão roubando ela? 
F: ... ininteligível....

R: E quem é essa pessoa aqui na frente?

F: Um primo.

R: Ah...; ele é parente dela.

F: É.

R: E ele está fazendo o que agora?

F: Ta saindo.

R: E ele vai escapar?

F: Vai.

R: E eles vão matar a mulher, ela vai morrer?

F: Vai.

$\mathrm{R}$ : E como vai terminar essa estória?

F: A polícia chega e prende os dois que mataram ela.

R: E o sobrinho, o que acontece?

F: Ele escapa.

R: Mais alguma coisa? Aqui, 9 RH, o que você vê aqui?

F: Um monte de gente ...(ininteligível).

R: Conta a estória disso, quem são? O que eles estão fazendo aí? Pra onde eles vão? De onde vieram?

F: Fazendeiros.

R: Fazendeiros...da onde eles vieram?

F: De uma fazenda, no interior.

R: O que eles foram fazer lá?

F: Eles foram lá arrumar alguma coisa melhor.

R: E nesse momento eles estão fazendo o que?

F: Dormindo.

R: E eles conseguiram arrumar alguma coisa melhor?

F: Não.

R: Não. E como vai ser daí pra frente?

F: Eles vão tentar voltar de novo pra fazenda.

R: Qual fazenda?

F: Do interior.

R: Onde eles moram ou onde eles foram procurar trabalho?

F: Onde eles moram.

R: Alguma coisa a mais? Prancha $13 \mathrm{HF}$, aqui, o que está acontecendo aqui?

F: Uma mulher deitada na cama e um homem chorando de pé.

R: Quem são essas pessoas? 
F: Marido e mulher.

R: E essa mulher ta deitada por que razão?

F: Ta morta.

R: E qual a razão da morte dela?

F: Briga, discussão.

R: Ele matou ela?

F: Matou.

R: Qual a razão? O que ela fez pra ele?

F: Não quis fazer amor com ele.

R: Não quis fazer amor com ele...e ele ficou com muita raiva.... e como é que ele matou ela?

F: Estrangulou.

R: E como vai ser o resultado disso?

F: Ele vai se sentir muito culpado.

R: E ele vai ser preso ou não?

F: Ele vai querer se matar.

R: E ele vai se matar ou não?

F: Vai.

R: Só? Prancha 14, o que você vê aqui?

F: Uma sombra de uma pessoa na porta.

R: Porta de onde? O que é isso aí? A pessoa ta saindo? Ta olhando?

F: Ta olhando.

R: Olhando pra onde?

F: Pra fora.

R: O que ela esta vendo lá fora?

$\mathrm{F}: \ldots$

R: E o que tem aqui dentro da casa?

F: Os objetos da casa, mesa, sofá...

R: Essa prancha te incomoda?

F: Não.

R: Que essa pessoa estava fazendo na casa?

F: Morgando.

$\mathrm{R}$ : E como vai terminar essa estória?

F: Ela entra de novo pra dentro da casa e fecha a porta.

R: Bom..., agora a ultima prancha, prancha 16, me conta uma estória . Pode por o que você quiser.

F: Eu, minha família, minha casa...meu irmão se recuperando...ficando em paz.

R: Você tem um sentimento de esperança que tudo vai dar certo. 
F: Tenho.

R: Só?

F: Só.

R: F. nós terminamos, talvez eu precise falar com você em um outro momento pra mais alguma informação ou só pra te dar um retorno, ok?

Obrigado. 


\section{ANEXO 4}

\section{Sujeito P (feminino)}

\section{Primeira entrevista:}

R: Bom dia P., hoje é dia 12 de janeiro de 2004, estamos aqui na AMC e eu vou conversar um pouco com a P., quando você nasceu?

Pf: 6 do 9 de 87.

R: Como é o nome da sua mãe?

Pf: J.

R: Qual a idade dela?

Pf: 37.

R: E o seu pai?; ta casado com ela ou ta separado?

Pf: Meu pai faleceu.

R: Como é o nome do seu pai?

Pf: A.

$\mathrm{R}$ : Quando é que ele morreu?

Pf: Ah! eu tinha 3 anos.

R: Você tem quanto agora?

Pf: 16.

R: Faz 13 anos que ele morreu, foi mais ou menos em 1990?

Pf: É.

$\mathrm{R}$ : $\mathrm{E}$ do que ele morreu?

Pf: De tiro.

$\mathrm{R}$ : O que aconteceu?

Pf: Assim pelo que minha mãe falou..., que ele tava descendo a rua lá da minha casa, aí tinha uns caras que não gostava dele, porque ele tava devendo não sei o que, aí os cara matou ele.

R: Você lembra?

Pf: Eu lembro de bastante coisa.

R: Você pode contar o que você lembra?

Pf: Eu lembro que logo que meu pai morreu, minha mãe conhecia uma mulher que ela fazia faxina na casa dela, como meu pai morreu a gente não tinha mais onde ficar, aí a gente foi pra casa dessa mulher, daí a gente ficou lá um bom tempo, aí minha mãe foi embora e eu fiquei lá, até quase pra fazer 10 anos de idade. A gente foi no Fórum aí minha mãe pegou minha guarda aí eu peguei e vim morar com minha mãe. E eu nunca mais vi ela.

R: Bem vamos voltar pro presente, você tem irmão mais velho ou mais novo? 
Pf: Mais velho.

R: Mais velho só......Qual o primeiro mais velho de todos, é homem ou mulher?

Pf: É homem.

$\mathrm{R}$ : E qual é o nome?

Pf: R.

R: Quantos anos?

Pf: 22.

R: A onde ele está?

Pf: Na casa da minha avó.

R: Com a sua avó...trabalha?

Pf: Não.

$\mathrm{R}: \mathrm{O}$ que ele faz?

Pf: Não faz nada.

R: Nada...fica lá.

Pf: Fica lá...

R: Ta envolvido com tráfico ou com droga?

Pf: Droga.

R: E mais irmãos?

Pf: Só ele.

R: Ah é só vocês dois...15 anos né...?

Pf: 16 .

R: Há quanto tempo você está aqui?

Pf: Aqui na casa?

R: Sim...

Pf: 3 meses.

R: 3 meses...e de onde você saiu?

Pf: Do Criança Cidadã.

R: Onde é o Criança Cidadã?

Pf: É lá perto das oficinas, é uma pensão de acolhimento só que lá não é pra ficar né,... lá eles te transferem ou pra tua casa ou se você, por algumas razões não pode ir pra sua casa eles te mandam pra outro abrigo.

R: Você ficou quanto tempo lá?

Pf: Fiquei 9 meses.

R: No Criança Cidadã...e onde você estava?

Pf: Na rua.

R: Na rua, lá na praça da Sé?; no centro? 
Pf: Não, lá na Marechal, eu tava lá, aí eu fiquei doente, eu fiquei muito mal, não conseguia nem levantar direito, aí me levaram pra delegacia, aí da delegacia me levaram pra lá.

R: Do que você adoeceu?

Pf: Eu tava com anemia.

R: Por que?

Pf: Porque quando eu estava na rua, como eu ficava cheirando cola, eu não sentia fome, então eu não comia, eu fiquei dois meses sem comer nada, cheirando cola e bebendo água, aí me deu anemia, aí eu fumava cigarro, me dava tontura e eu desmaiava, eu não comia, aí quando eu comia eu vomitava, aí me levaram no hospital, aí falaram que eu tava com anemia, aí eu fiquei no soro uns dois dias...

R: Quanto tempo você ficou lá na Marechal?

Pf: Lá eu fiquei bastante tempo, acho que mais ou menos um ano e alguns meses...

R: Um ano...e como era a vida lá, seus amigos, como é que você comia, dormia...

Pf: Ah ....a gente só comia quando pedia, ou senão quando tem gente, por exemplo de sexta em sexta, vai uns carros lá de noite levar marmitex pra quem mora na rua e uns lanches, aí eu só comia nesses dias, quando eles não ia a gente tinha que pedir, a gente pedia nas padarias e num monte de lugar e aí a gente comia, senão a gente não comia.

R: Você dormiu com fome alguma vez?

Pf: Tinha dia que a gente não conseguia nem dormir de tanta fome.

R: E quem que você vivia lá, como era a turma?

Pf: Ah ..., pessoas...

R: Sempre mudava, eram as mesmas?

Pf: Não sempre foi as mesmas, apesar que tinha duas meninas lá que elas tiveram que ir embora por que elas estavam devendo cola, aí elas foram embora, aí continuou as mesmas pessoas...

R: Durante quanto tempo?

Pf: Durante...10 meses, depois todo mundo foi se afastando, foi indo embora, aí só ficou, eu e mais três pessoas só.

R: Como eram as pessoas, conta um pouco, quem era legal, quem não era, quem eram os mais velhos e os mais novos.

Pf: É tinha dois que era mais velho e eles cuidava da gente né...

R: Eram homens.

Pf: Eram..., então, era assim, tinha uma menina que era muito folgada né, e aí a gente brigava, saia na mão, aí eles vinham e conversavam com a gente, aí a gente pegava, só que a gente não se falava, ela ficava no canto dela e eu no meu, e aí a gente conversava, eles eram super amigos assim da gente, cuidava da gente pra caramba...

R: Não maltratavam vocês não?

Pf: Não. 
R: Não pediam pra vocês roubarem, pra dar dinheiro pra eles?

Pf: Não, se a gente tivesse dinheiro, eles não queriam nosso dinheiro.

R: Nem sexualmente eles não queriam nada?

Pf: Não..., nada , nada...

R: Faziam mesmo de amizade.

Pf: É.

R: E eram mais velhos quanto?

Pf: Um tinha 20 e o outro tinha 23.

$\mathrm{R}$ : E o que eles faziam?; do que eles viviam?

Pf: É assim, eles estavam presos e eles saíram e estavam fazendo um serviço comunitário, aí nesse serviço ele conheceu um cara que trabalhava na marchetaria, aí o cara chamou ele pra trabalhar e ele tava trabalhando lá. Aí quando eles recebiam eles compravam roupa pra nós, comprava coisa pra nós comer.

R: Vocês tiveram muita sorte de achar esse pessoal.

Pf: É.

R: E eles moravam aonde?

Pf: Eles moravam lá na Sé.

R: Na rua mesmo?

Pf: Não sei, nunca perguntei pra eles se eles moravam, não parecia né que eles moravam na rua. Mas tinha vez que eles dormiam lá com nós, por que sempre passava uns cara lá, que eles vinham pra abusar nós, sabe, aí nós falou pra eles $\ldots$

R: E quantas meninas eram?; a turminha de vocês era composta de quem?; quantas meninas?; quantos meninos?

Pf: Tinha 5 meninas e uns 4 meninos.

R: Era sempre a mesma turma? E como é que era o dia de vocês?; o que vocês faziam?; cheiravam cola?; roubava?; pedia?

Pf: Não..., eu mesma acordava e aí tipo lá perto tem um Castelinho que quem é da rua pode tomar banho, aí eu ia, tomava banho, tomava café, aí eu ficava lá, sentada, pensando, aí nisso as meninas já tinham saído, mais cedo do que eu, já tinham ido comprar cola, voltava e ficava cheirando, aí eu ficava pensando,: Será que eu cheiro com elas?; será que eu não cheiro. Aí eu pegava e cheirava, né!!!! Aí ficava o dia inteiro lá, aí quando acabava a cola, nós saía pra pedir, né, nas padaria, pedia coisa pra comer, aí nós comia, e quando era de noite nós cheirava de novo e depois ia dormir.

R: E como é a cola pra você. O que é legal o que é ruim?

Pf: Ah... é horrível, eu nem cheiro mais porque é horrível. Oh, o primeiro bafo que a gente dá já vem aquele negócio, parece que ta tampando assim o seu ar, sabe. Aí ta, aí passa, aí se a gente dá mais duas baforadas aí começa dar tontura. Tipo assim, se você faz alguma coisa, depois você não se lembra, se você cheira muita cola, aí eu cheirei, cheirei, aí começa a dar tontura, aí você levanta assim, você vê tudo mexendo assim, tudo rodando assim, aí eu ficava no 
meu canto, aí você fala coisas que você depois não lembra, só os outros falando pra você que lembra, teve muitas coisas que eu fiz que eu não lembro.

R: E o que era bom na cola pra fazer você cheirar?

Pf: Ah!...porque tinha muitas vezes que eu ficava sentida né, porque eu não queria me desentender com minha mãe, e pra esquecer tudo isso eu ficava cheirando cola, aí quando já vinha na cabeça minha mãe, eu cheirava cola.

R: Como é que você foi parar lá?

Pf: Na Marechal?

R: É, você veio de onde? ; antes da Marechal você tava aonde?

Pf: Taiguara e no Taiguara eu saí na mão com uma menina, nisso eu machuquei ela e fiquei com medo de ir pra FEBEM, aí eu saí do Taiguara, aí eu peguei, comecei a andar pela Sé, pelos bares, e encontrei a G., que ela já morava na minha casa, que ela de rua, ela já morou na minha casa, e ela falou: Vamos lá pra Marechal, porque lá eu conheço um monte de gente e você fica lá, pelo menos você não fica aqui. Aí eu fui e conheci o pessoal de lá...

\section{R: E como você foi pro Taiguara?}

Pf: No Taiguara eu tava na rua, aí era umas 2 horas da manhã, aí eu chamei os policial, aí eu falei que queria ir pra um lugar que não queria mais ficar na rua, eu expliquei pra eles a situação, aí ele pegou e falou: Ah não tem nenhum lugar pra te levar a essa hora, então você fica aqui, na cabine com a gente, quando for de manhã trocar de plantão, pede pra eles levar você pra algum lugar, aí eu fiquei dormindo lá na cadeira, aí comi um pouco, aí quando foi de manhã, 7 horas quando trocou de plantão, aí me levaram pro Taiguara, lá no Taiguara elas me receberam e eu fiquei lá.

R: Quanto tempo?

Pf: Eu fiquei acho que duas semanas só.

R: E por que você brigou com a menina?

Pf: Por que assim ó, ela ficava com um menino que gostava de mim, só que eu não sabia que ele gostava de mim. Nisso ele pegou e terminou com ela, falando que não queria mais ficar com ela porque gostava de mim, e ela pensou que eu tava sabendo disso e ela começou a discutir comigo e aí eu peguei e bati nela.

R: Bateu muito foi?

Pf: Cortei aqui, mas aqui eu cortei foi sem querer, fui empurrar ela e ela bateu aqui, tinha uma ponta assim e ela bateu, aí eu fugi, pulei o portão e saí correndo.

R: Mas então antes de ir pro Taiguara você estava na rua? E como você foi parar na rua?

Pf: Porque assim ó: quando eu tinha 12 anos, a minha mãe tinha um caso com uma mulher, fazia 12 anos que ela estava curtindo com essa mulher, e quando eu fui morar com ela, elas já estavam juntas e eu e essa mulher se dava super bem, super bem mesmo, aí eu fui ficando maiorzinha né e comecei a sair com as minhas amigas, não sei o que, ela começou me prender.

R: Quem a mãe ou a mulher?

Pf: A mulher, e nisso a minha mãe não falava nada, nada, nada. Aí ta bom, aí eu fui só juntando né, ela me maltratava, tipo assim, ela não tinha obrigação de dar nada, mas eu pedia alguma coisa pra ela e ela não me dava, ela só mandava eu 
fazer as coisas, não deixava, que a gente morava num prédio, não deixava eu descer pra conversar com as meninas, o dia inteiro dentro de casa só limpando casa, indo pra escola e voltando, aí quando eu fiz 13 anos a minha mãe me bateu por causa dela, porque eu desci e não quis fazer nada dentro de casa, quando a minha mãe chegou do serviço ela falou que eu tinha xingado ela, não sei o que, um monte de coisa, aí eu peguei e fugi de casa, foi a primeira vez que eu fugi de casa, aí fui pra praia, fui pedindo carona, carona, carona, aí fui parar lá na praia, quando chegou na praia, era de madrugada, e a maré tava alta, eu fiquei super assustada, eu tava com medo né, nunca tinha ido pra rua, aí eu peguei e liguei pra minha mãe, falei pra minha mãe que eu queria voltar pra casa e aí minha mãe foi e me buscou, aí eu fiquei com a minha mãe, aí de mês em mês eu fugia de casa, aí quando eu fiz 15 anos, eu tava na minha casa, fazia um bom tempinho que eu tava na minha casa, aí foi meu aniversário e minha mãe fez festa, não sei o que, e quando foi no outro dia, pela primeira vez essa mulher tinha me batido, e ela é policial, e ela tinha me batido, e aí eu falei que ia embora de casa e disse que nunca mais eu ia voltar, aí eu fui embora, e minha mãe não queria, aí ligava pra minha mãe, e minha mãe falou assim: - Você foi pra rua porque você quis, eu não quero mais você, não sei o que, não sei o que. Aí eu comecei a ficar na rua, comecei a ir procurar um monte de lugares, foi aí que eu fui pro Criança Cidadã, aí eu comecei a ficar na casa dos outros, quando não ficava na casa dos outros eu dormia na rua, aí eu só fui ver minha mãe foi agora que eu vim pra cá, agora que eu to vendo ela.

R: E essa mulher..., como é nome dela?

Pf: K.

R: Quer dizer que depois que seu pai morreu, sua mãe se juntou com ela e ficou o tempo todo, e ta até hoje...

Pf: Não, agora elas terminaram, faz uns 8 meses que elas terminaram já, porque a mulher ficou com outra mulher e minha mãe viu.

$\mathrm{R}$ : $\mathrm{E}$ isso mudou alguma coisa para você?

Pf: Mudou..., nossa minha mãe mudou completamente, ela ta mais carinhosa, ela da mais atenção, ela não pensa só nela e na mulher, ela ta namorando com um cara agora, mas ela pensa primeiro nos filhos dela, pra depois ela pensar no cara que ela ta junto, mudou bastante.

R: E isso te dá esperança de você se entender melhor com sua mãe?

Pf: Já deu esperança, sabe por que, minha mãe vai alugar uma casa, porque ela ta morando numa pensão né, então é muito pequeno, lá mora ela meu irmão e minha avó, então se eu for, alem de aumentar o negócio, eu vou pegar e..., vai ficar muito apertado, aí minha mãe vai alugar uma casa lá no Imirim, vai comprar os móveis, depois que ela comprar os moveis, eu vou pra lá.

R: Sua mãe trabalha com o que?

Pf: Numa lanchonete, perto do Fórum da Barra Funda.

R: E a sua avó sempre morou junto?

Pf: Não, só com meu irmão, minha avó pegou meu irmão ele tinha 5 dias de nascido.

R: E ele viveu a vida toda com ela.

Pf: Ele chama minha avó de mãe.

R: E vocês estavam sempre juntos com a sua avó e seu irmão, ou... 
Pf: Não..., raramente eu via minha avó, só via ela quando era aniversário dela, que minha mãe me levava.

R: Ela morava perto ou morava longe?

Pf: Ela sempre morou lá na Estação da Luz, sempre.

R: E vocês moravam aonde?

Pf: Lá no Jaçanã.

R: E agora por que a sua mãe pegou a sua avó e seu irmão pra morar?

Pf: Porque..., não, esse prédio que minha mãe tava morando era da mulher que ela tava junto, então como elas terminaram né, a minha mãe não ia ficar lá né, então ela pegou as coisas dela e foi pra casa da minha avó.

R: Ah!..., e a tua avó que tava na pensão.

Pf: É a minha avó.

R: A pensão é onde a sua avó estava.. Então agora quer alugar uma casa.

Pf: Só que minha avó não quer ir, quer continuar na pensão e então minha mãe vai levar eu e meu irmão.

R: E teu irmão quer ir?

Pf: Não, ele falou que não quer ir, ele quer ficar com a minha avó..., ele não quer ir com a minha mãe. Minha mãe falou : - Tudo bem, você fica aí, qualquer final de semana você vai lá, passa o final de semana lá, mas a P. vai, aí eu falei que eu vou.

R: Você está interessada...

Pf: Eu sempre quis morar com a minha mãe, depois se não fosse por essa mulher eu não tinha nem fugido de casa, não sabia nem o que era rua...., mas por causa dessa mulher..., sempre falei pra minha mãe que a culpada era ela, minha mãe: - Não, você que gosta de rua, você que não sei o que.

R: E me conta como é que era a relação com a sua mãe?; o que você lembra?; como é que era?; como você se sentiu com ela?; como ela te tratava?; o que você acha que ela sentia por você?

Pf: Não eu acho que a minha mãe..., ela não dava a mínima pra mim, porque, toda vez quando era o meu aniversário, ela saía, ela não ficava comigo, ela saía ia pra baile, então ela dava mais atenção pra mulher do que pra mim e pro meu irmão, tanto que o meu irmão foi até morar com a minha mãe, ficou morando eu meu irmão minha mãe e essa mulher, só que essa mulher começou a pisar na do meu irmão também, meu irmão falou: - Eu não quero ficar aqui. Minha mãe falou: - Você gosta de rua e não sei o que, eu não quero mais você. E aí nós foi embora. E quando foi agora ela se arrepende de tudo o que ela fez. Ela falou que se ela não tivesse se envolvido com essa mulher, acho que nenhum dos filhos dela estaria envolvido no mundo de droga, estaria andando em abrigo, aí eu falei: É, quando eu falava pra você que ela que maltratava a gente, você não acreditava. Agora ela ta arrependida.

R: Você estudou?

Pf: Estudei.

R: O que você estudou?

Pf: Estudei até..., eu terminei a sétima. 
R: Desde pequena a tua mãe te pôs no colégio?

Pf: Desde pequena.

R: Teu irmão também?

Pf: Meu irmão também.

R: Sétima, aí falta a oitava do primeiro grau e aí vai pro segundo, né?

Pf: É.

R: E você pretende acabar?

Pf: Esse ano eu vou estudar, porque hoje eu vou lá no serviço da minha mãe, pra pedir pra ela ir na escola tirar meu histórico porque a tia foi, só que elas não dão na mão da tia, só na mão da minha mãe, aí eu vou lá no serviço dela hoje e vou pedir pra ela ir na minha escola.

$\mathrm{R}$ : E me conta mais como eram as histórias com essa mulher...lembra de algum fato?

Pf: Ah eu lembro de bastante coisa, eu lembro assim ó: quando era aniversário da minha mãe ela vinha com flor, um monte de coisa, aí uma vez, eu nunca me esqueço, era aniversário da minha mãe, ela veio com uma caixa, com 3 CDs dentro e um monte de bombons, aí elas entrou no quarto e fecharam a porta, nisso eu queria descer pra brincar, aí eu peguei e falei - O que ta acontecendo?; aí fui olhar pelo buraco da porta, quando eu olhei, as duas estavam se beijando, aí eu fiquei com nojo da minha mãe, quando a minha mãe saiu eu tava chorando; ela: Por que você ta chorando? - eu: -Nada não. Eu não conseguia nem olhar pra cara da mulher assim...

\section{R: Quantos anos você tinha?}

Pf: Eu tinha...acho que 10 anos, aí nisso..., aí eu cheguei na minha mãe conversei com a minha mãe, eu falei pra ela que eu tinha visto, e quando elas quisessem se beijar que fizessem quando eu tivesse brincando, aí sempre quando era aniversário da minha mãe elas iam pra um motel, elas nunca ficavam em casa, eu ficava sozinha em casa, elas me trancavam e eu ficava sozinha até o outro dia de manhã, aí foi sendo assim, foi sendo assim, aí teve um dia que uma amiga da minha mãe, que também é sapatão, tava lá em casa, nisso essa mulher gosta da minha mãe e aí minha mãe tava fazendo comida e eu tava na sala escrevendo né, escutando musica, quando eu vou na cozinha a minha mãe tava cortando... acho que era pepino, e a mulher tava por trás da minha mãe abraçando ela, aí eu olhei assim, nossa mas eu xinguei muito a mulher e isso não saia da minha cabeça, sempre quando eu via a mulher da minha mãe, a K. f., eu chorava, um dia tava eu e ela e minha mãe tava trabalhando, aí eu cheguei nela e contei tudinho que tinha acontecido pra ela, aí ela foi buscar minha mãe, contou pra minha mãe, minha mãe falou que era mentira, que eu tava louca, aí quando ela chegou ela me deu uma surra, eu fiquei toda roxa, aí eu comecei a ir embora de casa...

R: E você, como é que são os seus namoros?; você namora com homem?; com mulher? tanto faz?

Pf: Não, eu namoro com homem, nunca fiquei com mulher não, nem tenho interesse de ficar.

R: E você se sente à vontade nos seus namoros com homem, ou é complicado?

Pf: Não eu me sinto..., dependendo da pessoa eu me sinto bem porque quando eu saí de casa, eu tive meu primeiro namorado e aí ele era traficante e ele me 
batia muito, então quando algum menino vem pra ficar comigo eu já falo que não, ficava super assustada.

R: Que idade você tinha?

Pf: Eu tinha 14 anos, foi meu primeiro namorado.

R: E ele tinha quanto?

Pf: Ele tinha 18, mas ele me batia muito mesmo, nossa eu não podia sair no portão e ele me batia, e nisso eu não sabia me defender e a irmã dele também, sempre que me via na rua me batia né, porque ele não queria que eu saísse então..., aí eu fui.., aí depois dele eu nunca mais me ..., vim namorar agora aqui na casa, to namorando com o D., mas assim, a gente briga muito, a gente discute pra caramba, porque ele é um cara que é muito ciumento, - você vai aonde?; tira essa roupa!; não sei o que - mas a gente se dá bem, depois desse namorado que eu tive que ele me bateu eu acho que eu só tive um e o D., que eu fiquei super assustada, com medo que eles me batessem de novo.

R: E sexualmente, você teve vida sexual, tranqüilo?

Pf: Tive, mas com meu primeiro namorado, foi porque eu me senti obrigada, eu me senti obrigada a ter que perder minha virgindade com ele, eu me senti obrigada a ter relação com ele, depois dele eu não tive com mais ninguém, só voltei com o D., só.

R: Medo.

Pf: É.

R: Você acha que seu pai fez falta na sua vida?

Pf: Faz, muita falta, eu acho que se meu pai estivesse vivo nada disso teria acontecido, o meu irmão não tinha ido pra FEBEM, eu não tinha ido pra rua, a minha mãe não tratava a gente do jeito que ela tratava, que nem ela falava: Ah, se seu pai estivesse vivo, ele te arrebentava. Eu sempre falava pra ela: - Se meu pai estivesse vivo, acho que nada disso estaria acontecendo, porque você não estaria com ela, estaria com meu pai, e tava tudo bem, eu e meu irmão tava estudando, voltando pra casa com uma vida normal. Aí ela sempre falava: - Não vocês gosta de rua, se seu pai tivesse aqui, que não sei o que...Aí sempre, sempre de noite eu rezava, tipo ficava falando com meu pai assim; que ele tava vendo que a gente não tava errado, pelo que a gente tava sofrendo, pelo que a gente sentia falta dele. Quando eu tinha 15 anos que a minha mãe foi mostrar uma carta que ele deixou pra mim e pro meu irmão, aí tava escrito que era pra gente cuidar da minha mãe, que era pra se eu se envolver com alguém pra tratar essa pessoa bem, e que era pra cuidar do meu irmão, não era pra mim se envolver em drogas, não ter as amizades que eu tenho, até quando eu li eu comecei chorar, minha mãe começou chorar, aí eu perguntei pra ela,: - Por que você ta chorando? Você falou que não gosta mais dele, que não sente mais nada por ele e gosta da Kátia, que você ama a K. f., aí ela ficou com raiva, nem falou comigo, eu peguei desci, aí fui embora de casa. Teve uma vez também que eu tava..., desse menino que eu apanhei, eu cheguei uma vez no portão da minha casa toda roxa, minha mãe deixou eu entrar, aí passou um mês, aí eu tava começando a sentir enjôo, aí eu fui no hospital, aí falou que eu tava grávida, minha mãe não queria eu grávida de jeito nenhum, ela falou que era pra mim escolher, ou eu ia morar com ele ou ia pra rua, mas ficar grávida dentro de casa eu não ia ficar. Nisso minha mãe conheceu um cara que era de macumba, aí a minha mãe pegou, pediu pra K. f., como ela era policial, né, fazer um negócio assim de maconha que era pra deixar pra mim tomar, e eu falava que eu não ia tomar, que eu ia ter, não sei o que, que não, que eu não ia, que eu não ia..., 
nisso não sei o que aconteceu, de um dia pro outro, eu me revoltei falei que não queria filho, que não queria nada e nisso o cara já tinha ido em casa..., aí quando foi no outro dia, eu comecei me levantar, falei que não queria filho, que não sei o que, e nisso ele foi lá em casa, o macumbeiro, aí eu tava lá deitada, aí ele foi lá conversar comigo, aí ele falou assim: - Você ainda quer ter esse filho? Eu falava: não, não quero. Eu com raiva, muita raiva eu tava sentindo, não sei o que tinha acontecido que eu tava sentindo muita raiva.

R: Quer dizer, antes dele fazer o trabalho você queria ter o filho.

Pf: Depois que ele fez me deu um..., muita raiva, aí nisso eu começava a me sentir mal, eu vomitava, aí ele me deu um chá pra mim tomar, aí eu tomei o chá, aí nesse chá, não sei o que tinha, mas parecia que era pra eu ter mesmo, aí ele dava soco na minha barriga, dava soco, fazia vários trabalhos em cima da minha barriga e nada de descer, quando eu fui pra rua, aí eu peguei, fui pra rua, e fui atrás do cara que eu tava, que era o cara que eu falei, que eu tava grávida, e que minha mãe tinha feito vários trabalhos de macumba, pra mim perder, que não sei o que e eu não perdi. Aí nisso ele falou que era pra eu ficar na casa dele, que ele ia assumir e tal. Nisso a minha mãe foi atrás de mim, no que a minha mãe foi atrás de mim, eu saí, e esqueci de avisar ele, no que eu saí, a irmã dele me catou na esquina, me bateu, me bateu, e eu não sabia me defender ainda, né, me bateu, me bateu, me bateu, aí ela pegou um pedaço de pau e deu na minha barriga, no que ela deu, eu já e senti a dor começou a descer. Aí eu peguei, fui na Igreja, aí pedi pra tirar todo o mal que tava dentro de mim, contei o que tinha acontecido pro cara lá, aí ele rezou por mim, aí quase todo dia eu ia na Igreja, aí minha vida foi melhorando, depois que começou fazer esses trabalhos, nossa eu só tinha vontade de fazer coisas ruins, falava pra minha mãe que eu não gostava dela, eu xingava ela de tudo que era nome, não ficava em casa de jeito nenhum, quebrava prato, quebrava um monte de coisa. Depois que esse homem parou de ir lá na casa, aí eu fui uma vez visitar minha mãe, isso foi no dia das mães, aí tava tudo tranqüilo. Sempre que eu entrava em casa, logo que eu entrava, já me dava aquela dor de cabeça, eu chegava da escola, já me dava uma dor de cabeça, aí eu não comia, aí eu fazia lição, tanto que eu fazia lição na casa da vizinha, que eu não agüentava fazer lição naquela casa. Pra dormir era o maior sacrifício, eu virava pra um lado, virava pro outro, e não conseguia dormir, e eu tinha que acordar as sete horas pra ir pra escola, aí eu ia pra escola morrendo de sono, aí eu chegava na escola, eu dormia. Aí eu expliquei pra professora o que tava acontecendo, aí ela passou tudo numas folhas assim, tirou xerox e me deu pra mim copiar, que eu não conseguia dormir, de jeito nenhum, depois que esse cara parou de ir lá que..., nossa parecia um mar de rosas.

R: Você se lembra do teu pai quando ele era vivo?

Pf: Lembro.

R: O que você lembra?

Pf: Nossa o meu pai, ele era assim, ele era do tipo da pessoa assim, ele batia na minha mãe, porque a minha mãe deixava a gente chorando em casa e ia pro samba, pro baile, sabe, meu pai ia buscar ela, chegava em casa, meu pai batia, aí meu pai pegava eu no colo e falava assim: - Filha eu sei que tudo o que você viu agora, quando for mais tarde, quando você for mais velha, você vai lembrar, mas o que o pai fez com a mãe agora foi porque ela deixou vocês chorando. E eu mamava no peito ainda, só meu irmão mamava na mamadeira, aí ele falava assim que conforme o tempo eu ia me lembrar e nunca ia me esquecer, e parecia que ele já sabia que ele ia morrer, ele falou assim: - Se um dia o pai morrer, quando você tiver sofrendo, eu sempre vou estar do seu lado, sempre 
vou aliviar um pouco o seu coração pra você parar de sofrer. Sempre quando eu choro, assim..., eu lembro das coisas que ele falou, ou eu pego no sono, ou eu paro de chorar.

R: Tranqüiliza você...

Pf: É.

R: Ele deixou uma coisa boa pra você, uma lembrança boa.

Pf: Deixou.

R: Que mais você lembra dele.

Pf: Lembro quando ele me levava pra passear, ele era mais apegado a mim que ao meu irmão, meu irmão é apegado mais à minha mãe. E aí ele saía comigo e quando ele não tava brigado com a minha mãe, saía todo mundo junto. Aí, todo dia ele falava: - Filha, se um dia eu morrer, sempre vou estar olhando, por você. Minha mãe falava assim que meu irmão ficava falando: - Que pai, você não vai morrer não, você vai ficar com a gente. Meu pai: Não, mas se um dia eu morrer, sempre eu vou estar com vocês.

R: E o que você acha disso? O que você sentia quando ele ficava insistindo que ia morrer?

Pf: Ah..., eu achava que ele tava ficando louco, que nada disso acontecer, porque como a gente era pequeno, não tinha como ele explicar o que estava acontecendo. E a minha mãe todo dia de noite chorava, aí....eu sem saber de nada, nem ligava pra minha mãe, aí quando eu fiquei mais velha minha mãe foi me contar que meu pai tava devendo pra uns caras, e que se os cara não conseguisse catar meu pai, ia catar ou eu, ou meu irmão, ou minha mãe. Aí eu falava assim: Então é por isso que meu pai sempre me falava que ia morrer, ia morrer..., acabou morrendo. Antes, eu era mais traumatizada, eu começava falar do meu pai eu chorava que nem uma criança, agora eu já me conformei mais, mas antes...

\section{R: Qual era o seu sentimento?}

Pf: Eu fico sentindo falta, eu colocava na cabeça por que meu pai não ta aqui comigo agora, por que isso ta acontecendo? E nisso eu sempre me perguntava, né, porque meu pai não ta aqui? porque?; porque?; quando a A. tava conversando com as amigas dela: - Ah..., e o pai da P.?; - Ah..., ele faleceu. Aí eu começava chorar, não podia falar do meu pai que eu chorava. Agora não, agora eu me conformo mais, já consegui me conformar que ele morreu. Mas no começo eu não acreditava que ele tinha morrido não, eu pensava que ele tinha me abandonado. Quando eu li a carta que eu fui me conformar.

R: Quanto tempo demorou isso que você não acreditou que ele morreu?

Pf: I che foi bastante tempo.

R: Você não viu o enterro?

Pf: Não, nada. Nem assim, nem foto com meu pai eu tenho, eu lembro como ele era, mas foto com ele assim...

$\mathrm{R}$ : Como era com ele e a tua mãe, quando você era pequena, o que você lembra?

Pf: Eles raramente brigavam, era raro eles brigar, então, meu pai não podia ver eu chorando que ele já vinha e ficava me agradando, os dois raramente brigavam, ficavam num clima bom assim sabe. Minha mãe cuidando de mim e de meu irmão, ele ia trabalhar, voltava e ajudava minha mãe cuidar de nós. 


\section{R: Ele trabalhava com o que?}

Pf: Ele trabalhava de borracheiro..., então era um clima legal.

R: E da sua mãe, o que você se lembra quando você era pequena?

Pf: Iche, minha mãe, eu não lembro muita coisa não. Como eu sinto mais falta do meu pai, então pelo fato de eu sentir mais falta eu lembro mais dele. Da minha mãe eu não lembro...

\section{R: O que você acha que seu pai deixou pra você?}

Pf: Que nem a minha mãe diz, eu sou que nem o meu pai, porque se eu decidir uma coisa, é aquela coisa e ninguém tira da minha cabeça, pode ser a coisa mais errada do mundo mas ninguém tira da minha cabeça. Ela fala que eu sou que nem o meu pai: que eu sou decidida, que eu sou encrenqueira, e tem várias qualidades que o meu pai tem, que eu tenho e meu irmão não tem.

\section{R: Quais?}

Pf: Que eu sou, eu sou muito sentimental, que se eu brigo com uma pessoa agora, depois a pessoa a pessoa começa a me xingar, eu xingo na hora, mas depois eu fico num canto, começo chorar, a pessoa grita comigo eu to chorando, e meu pai era assim, meu pai brigava com a minha mãe, dali a 5 minutos ele tava chorando. Aí meu pai ele era super carinhoso, e eu me apego às pessoas muito rápido, muito rápido mesmo, eu me apego muito fácil, com as tias eu me apego fácil. Se as meninas maltrata as tias, começa xingar as tias, que nem a $\mathrm{C}$. f., a C. f. é super gente fina, as meninas xinga ela, ela começa a chorar, aí eu vejo ela chorando eu começo a chorar, já fico com raiva das meninas, quero bater nas meninas, e aí eu não posso ver ninguém chorando que já começo a chorar. Meu pai era assim, ele gostava de ajudar bastante gente, e eu por mais que eu não tinha nada, deixava de comer pra dar pros outros. Tirava minhas roupas e emprestava, era tudo roupa nova, e eu emprestava, não tava nem aí. Eu queria ver a pessoa bem...., meu pai era assim, ele não tinha, mas o que ele tinha ele dividia com as pessoas.

R: E a tua mãe, como era, como você descreve a tua mãe?

Pf: Ah!..., minha mãe é um pouco arrogante, ela é bem mais fechada.

R: Como assim.

Pf: Ela é carinhosa em tudo, só que ela não gosta de demonstrar. Ela é mais fechada, ela é no canto dela, que nem o meu irmão, o meu irmão é....., gosta da namorada dele só que não demonstra, diz que não gosta, nem liga pra ela. Que nem a minha mãe, a minha mãe quer chegar em nós, quer fazer um carinho, só que ela tem medo de fazer e depois a gente pegar e dar mancada com ela: - Ah pra que eu agradei então?

R: E você acha que ela deixou alguma coisa pra você?

Pf: Não.

R: Você não tem nada dela...

Pf: A única coisa que ela deixou mesmo, que eu aprendi muito com ela, foi que ela vivia me falando, que quando eu ia pra rua e voltava pra casa, ela vivia me falando: - Filha, toma cuidado, você pode pegar uma doença. A gente conversava de tudo, eu e minha mãe, sabe, de namorado, de sexo, de doença, de tudo. Ela sempre me falou que era pra mim tomar cuidado, pra sempre tomar remédio, usar camisinha quando for ter relação, de coisas boas assim foi isso, só 
isso, porque coisa de festa assim, é só o momento, e eu e minha mãe saia bastante.

\section{R: Coisa de festa é só o momento, como assim?}

Pf: Ah porque eu e minha mãe saía bastante, então nós ficava dançando, parecia que a gente sempre teve aquele amor uma pela outra, só que era só na festa, chegava em casa a coisa mudava, sabe, parecia que ela só queria mostrar que estava feliz assim, perto da gente, porque as amigas dela tava ali.

$\mathrm{R}$ : Como era o temperamento da tua mãe, você pode falar mais alguma coisa?

Pf: A minha mãe tinha dia que ela acordava num bom humor daqueles, tinha dia que ela acordava, qualquer coisinha que a gente falasse pra ela, era motivo dela pegar ou deixar a gente de castigo ou dar uma surra na gente, tinha dia que ela tava triste, a gente ia conversar com ela e ela não falava nada, só chorava, e escrevia na agenda e ela não deixava a gente ver a agenda dela, e a gente perguntava: - Mãe o que ta acontecendo, fala pra mim. ela dizia: - Não vou falar, é problema meu, vai lá pra baixo se divertir. Eu não consegui ficar brincando, pensando que a minha mãe tava lá encima triste. Aí minha mãe ficava dias triste, aí quando a K. f. chegava elas conversavam e aí ela mudava. Quando minha mãe tava feliz, nossa era uma maravilha, a gente ficava em casa, a gente ligava o rádio, a gente limpava a casa toda, a gente ia no mercado juntas.

R: E a sua mãe se importava com os seus estudos, com a sua formação?

Pf: Sempre, sempre quando eu arrumava briga na porta da escola, ela ia lá, porque, eu sou assim, enquanto eu não descontar a minha raiva eu não saio dali, teve uma vez que a menina pegou e abaixou minha calça no recreio, e nesse dia eu não sabia que minha mãe ia na porta da escola, aí eu peguei e dei o material pro menino, fui lá na frente, era hora da saída, aí comecei a bater na menina, a minha mãe apareceu e separou, quando eu olhei pra trás era a minha mãe, aí ela conversou com a diretora. Aí chegou em casa ela conversou, aí eu expliquei pra ela. Eu nunca tive nota baixa na escola, agora meu irmão não, eu sempre tive nota boa, ela sempre me ajudou, que eu sempre falava pra ela que eu queria me formar em medicina, queria ser pediatra, aí ela sempre me ajudava, acabar os estudos logo.

R: E a K., o que ela deixou pra você?

Pf: De bom?

R: Ou ruim.

Pf: Eu acho que conviver com ela, pra mim, não foi uma experiência boa, porque, dizem que mulher dá mais valor que homem, né, mas pra mim ela não é desse tipo de mulher não, ela é muito ignorante, apesar que no começo assim, eu nunca tinha tido uma festa de aniversário, quando eu fiz 10 anos ela me deu, nossa foi o maior festão, eu fiquei muito feliz, e depois desse dia as coisas foram mudando, ela foi me maltratando..., ela tinha muito ciúme da minha mãe, e sempre que eu e minha mãe tava se entendendo, ela sempre fazia alguma coisa pra nós brigar, então eu fui percebendo e aí eu fui descrevendo ela, falando pra minha mãe, só que minha mãe nunca acreditava. Pra mim ela não deixou nada de bom.

R: Teve alguém importante que marcou a sua vida?

Pf: Além da minha mãe?

R: Além da sua mãe e do seu pai. 
Pf: Uma amiga da minha mãe, sinto muita falta dela. Ela também é sapatão, só que ela me tratava muito bem, muito bem mesmo. Quando eu tava de aniversário, a K... a gente nunca se falava, né, aí ela vinha, passava o dia inteiro comigo, a gente saía. Quando eu fui no serviço da minha mãe, aí ela ligou no telefone, foi antes do Natal, aí ela começou a chorar, que era época de Natal, começou a chorar, aí eu ia até pegar o telefone dela pra gente sair. Nossa eu gosto muito dela, muito, muito...

R: Como é o nome dela?

Pf: $V$.

R: V. E o que ela deixou pra você assim?

Pf: Ela era uma pessoa muito carinhosa, foi a pessoa que eu mais me apeguei assim, quando eu fugia de casa eu ia lá e conversava com ela, quando eu tava desconfiando que tava grávida eu ia conversava com ela, ela arrumava remédio pra mim, quando eu ficava com medo que eu chegava muito tarde, eu ficava com medo de ir pra casa, eu ia e conversava com ela pra ela ligar pra minha mãe, e minha mãe sempre escutava ela, tudo o que eu pedia pra ela, ela fazia. Quando era fim de semana a gente ficava lá em casa dançando, a gente ficava lá, perto dela eu me sentia muito bem. Preferia que a minha mãe tivesse ficado com ela do que com a K.

R: V...., e você ainda vê ela?

Pf: Não, nunca mais eu vi ela, só falei por telefone no dia 24.

R: E por que você não procura por ela?

Pf: Não, porque, ela morava perto da minha casa, com outra mulher, que era mulher dela, amiga da minha mãe também, e elas duas se separaram, e ela ta morando na Lapa e a minha mãe só tem o telefone dela, e o dia que eu fui pra lá visitar a minha mãe, eu peguei, ela ligou, conversei com ela né, choramos e ela falou que ia marcar um dia pra nós sair, só que nisso eu esqueci de pegar o telefone, aí hoje eu vou e vou pegar o telefone com a minha mãe.

R: Você teve alguma doença na sua infância?; juventude?

Pf: Não.

R: Teu irmão?

Pf: Meu irmão tem..., vira e mexe ele fica com falta de ar, ele usa muita maconha, é 24 horas usando maconha, então, tem hora que ele fuma muito, aqui prende, e ele começa a ficar roxo, e aí a gente leva ele pro hospital, mas o médico disse que tem uma hora que não vai ter chance, pra ele maneirar ou senão pra ele parar. Mas ele não consegue mais parar. Minha avó já levou ele pra clínica, ele vai pra clínica, passa um mês ele foge.

R: E o teu irmão foi pra FEBEM por que razão?

Pf: Tava roubando, aí agora ele ta com quebra de L.A. , se ele levar algum enquadre ou se a polícia parar ele, ele volta pra FEBEM.

R: Você já esteve na FEBEM?

Pf: Não.

R: Como é que você se sente aqui?

Pf: Aqui na casa? Ah eu me sinto bem.

R: Quais são os seus planos? 
Pf: Ah! eu quero terminar primeiro os meus estudos né, começar a trabalhar, pagar minha faculdade, ter minha casa, meus filhos, quero ter uma vida normal.

R: E por enquanto você vai ficando por aqui.

Pf: É vou começar a estudar..., aí se eu não for morar com a minha mãe, eu vou ficar aqui.

R: E as drogas como estão hoje em dia?

Pf: Eu não to mais usando droga.

R: Não.

Pf: Sempre saio pra rua, vejo os outros cheirando, fumando maconha, mas eu não vou fumar, eu até me afasto.

R: Quem são suas amigas hoje?

Pf: Amigas, amigas..., eu não tenho amigas.

R: Não tem.

Pf: Acho que amiga mesmo é só a V. f., essa que eu tava falando pra você, só ela.

R: Como é a sua relação aqui na casa com as pessoas?

Pf: Ah!, eu gosto de todo mundo né, mas sempre tem uma preferência né. Dos educadores eu gosto do R. m., do tio G. m., da tia N. f., da P. f. e da A. f., agora dos educandos, do D. m., da C. f. e do A. m., só, os outros eu converso assim mas não é um sentimento assim como eu tenho pelos outros.

$\mathrm{R}$ : O que esses educadores tem que te cativam?

Pf: Ah!, eles são..., assim quando eu to cheia eles entendem, a gente conversa eles me entendem bastante, eles são super carinhosos comigo.

R: Você se sente acolhida?

Pf: Me sinto bastante, porque nos outros lugares que eu fui no segundo dia eu já queria ir embora, aqui não, já faz 3 meses, e eu não tenho vontade de ir embora.

R: Não..., o que fazia você sentir vontade de ir embora nos outros lugares?

Pf: Porque a gente se sentia muito presa, não podia sair, não podia fumar, não podia fazer nada, tinha que ficar lá, usar a roupa da casa, eu não me sinto..., eu não escolhi aquela roupa da casa, eu gosto de usar as minhas roupas, aqui não..., eu mesmo me sinto na minha própria casa porque aí eu faço a minha escala, eu fumo, eu saio, eu vou ver minha mãe, eu saio com ela, eu volto.

R: Você tem o seu jeito de ser respeitado né?

Pf: É.

R: Nos outros lugares, você não podia ser você.

Pf: Não, tinha que ser o que eles queriam.

R: Ta bom, então hoje a gente já conversou bastante, e eu tenho mais coisas pra conversar com você e queria voltar outro dia, tudo bem?

Pf: Tudo.

R: Então obrigado por hoje. 


\section{Segunda entrevista:}

Bom P. hoje é dia 15 de janeiro de 2004, então hoje é o segundo dia que a gente conversa, e vamos continuar com mais algumas perguntas

R: Qual é a pior coisa que já aconteceu pra você?

Pf: Pior coisa? Desde a época que eu saí de casa até agora?

R: De toda a sua vida.

Pf: Foi duas coisas: a primeira foi o fato da minha mãe ter me trocado por uma mulher, e a segunda coisa, foi o dia que ela levou o macumbeiro lá e tentou tirar o neném. Foram as piores coisas que me aconteceram, que eu nunca imaginei que ia acontecer, ainda mais com a minha mãe.

R: Você não esperava isso dela.

Pf: Não.

R: E qual é a pior coisa que poderia acontecer na sua vida?

Pf: A pior coisa que poderia acontecer seria eu ser estuprada, que acho que na hora eu ia ter um piripaque, porque eu acho que eu iria querer reagir.

R: E qual é a melhor coisa que já aconteceu na sua vida?

Pf: Foi quando eu fui morar com a minha mãe, foi poucos momentos que a gente ficou junto.

R: Quando foi?; qual das fases?

Pf: Foi no meu aniversário de 10 anos, e até os 13 anos foi os melhores tempos, a gente era super amiga, a gente ficava super junto, ela não dava tanta atenção pra K. f., e dava mais atenção pra mim, não sei se era pelo fato de eu ter morado na casa dela, de eu ter chegado hoje na casa dela assim, ela tava me tratando assim.

$\mathrm{R}$ : Antes você estava aonde?

Pf: No J abaquara.

R: Com quem?

Pf: Com a mulher que me criou.

R: Quem é essa mulher?

Pf: É a dona D., ela é mãe de uma amiga da minha mãe, que quando meu pai morreu minha mãe não tinha mais onde ficar, aí a gente foi pra casa dela, aí eu fiquei na casa dela e minha mãe conheceu essa mulher e já foi morar com a mulher, e eu lá, até meus 9 anos, quando eu ia fazer 10, minha mãe foi pro juiz pedir minha guarda.

R: Dona D. é aquela mulher que a tua mãe trabalhava..

Pf: É.

R: Aí ela teve que sair e essa mulher ficou com você. Por que é mesmo que a sua mãe teve de sair?

Pf: Não, ela saiu assim mais porque ela quis, entendeu, porque ela conheceu essa mulher.

R: Ah!..., e que idade você tinha? 
Pf: Acho que eu tinha uns 4 anos.

R: E como foi a sua vida com a dona D.?

Pf: Ah!..., foi muito boa, eu estudava, ela dava tudo que eu queria, ela me tratava com o maior carinho, eu ficava lá no portão com ela sentada., quando ela passava mal..., eu era pequeninha mas eu ficava desesperada, sempre chamei ela de vó, vó, nunca chamei ela de dona D.;

R: Ela morava sozinha?

Pf: Não, ela tinha filhos, um filho dela é casado e ele é meu padrinho, ele me batizou, tem outro que morreu, ele tinha 7 ou 8 anos, ele morreu, aí eu fiquei desesperada, chorando, não comia, que eu era apegada a ele bastante, porque ele morava na rua de cima e quase todo dia eu ia na casa dele, quando era época de Natal ele levava um monte de coisa, eu era muito apegada a ele, aí quando ele morreu eu senti a maior falta dele, fiquei vários dias sem comer, no enterro dele eu queria entrar na cova de qualquer jeito, um monte de pessoas tentando me tirar, aí foram 5 caras lá, me tirar, eu não tinha me conformado.

R: Conta um pouco mais da dona D. e da sua vida lá. Você tinha amigos?

Pf: Tinha, aonde a gente morava lá era viela com um monte de casa, a minha casa era a ultima então tinha a mulher do lado, mais pra frente tinha umas meninas, tinha uns meninos que moravam perto da minha avó e a gente era tudo como um irmão ali, sabe, a gente saía junto, a gente ia pra escola junto.

R: Ninguém fazia diferença que você não era filha dela?

Pf: Não, ninguém fazia diferença.

R: E você acha que a dona $D$. te tratava como uma filha?

Pf: Sempre me tratou, quando eu fui embora ela chorou, aí teve um tempo que eu ia, que eu fugia de casa eu ia lá ver ela, dormia na casa dela de 3 dias, depois ela mandava eu embora, aí eu ia pra rua de novo, depois eu voltava pra lá, e ela ...(ininteligível)...que eu ia pra rua e não tinha lugar pra ficar, sempre que eu ia pra rua eu voltava muito magra, aí ela explicava as coisas pra mim, explicava tudo e eu ficava lá.

R: Então você quando saiu da casa da dona D. foi pelo aniversário de 10 anos...

Pf: Eu fui pra casa da minha mãe...

R: Você saiu da dona D. porque?

Pf: Porque aí a minha mãe decidiu que eu continuasse com ela.

R: Ah..., ela foi no juiz.

Pf: Aí eu peguei e fui morar com ela.

R: E aí foi um momento feliz.

Pf: Foi.

R: E teve até a festa que a amiga da tua mãe fez...

Pf: É.

R: E esses momentos felizes demoraram 3 anos..aí foi ficando ruim, ruim, não é assim?

Pf: É.

R: Aí você saiu de casa de novo... Você sabe a estória do gênio da lâmpada? 
Pf: Não.

R: Não? Mas antes deixe eu te perguntar outra coisa, você me falou qual foi a melhor coisa que te aconteceu, né, e qual seria a melhor coisa que você gostaria que te acontecesse?

Pf: A melhor coisa que eu sempre sonho assim é; eu ter minha casa, fazer minha faculdade, que eu quero fazer faculdade de medicina, fazer minha faculdade, terminar os meus estudos, ter a minha casa, e um dia, quem sabe, casar, ter meus filhos, ter minha vida normal, tudo de ruim que aconteceu deixar pra trás, e viver como...(ininteligível)...

R: Como é deixar pra trás tudo isso? Isso daí ta dentro de você?; você sente isso tudo aí dentro?

Pf: Está e eu não consigo tirar por mais que eu tente, seja o dia mais feliz da minha vida mas eu não consigo esquecer.

R: E o que você lembra?

Pf: Ah!..., eu lembro de tudo, de tudo, os momentos ruins da minha mãe, os momentos bons...

R: Como um filminho que fica insistindo em passar?

Pf: É.

\section{Entrevista dirigida}

R: Então a estória do gênio da lâmpada, é assim: você viu aquela feiticeira? A Jeanne é um Gênio?

Pf: Sim.

R: Então é que nem aquilo, existe uma lâmpada que você acha, aí você esfrega e aparece um gênio, você faz três pedidos e ele realiza o que você quer, se você encontrasse o que você pediria?

Pf: O que eu pediria? Se fosse agora assim, né?

R: É.

Pf: Eu pediria pra eu voltar pra eu morar com a minha mãe, a primeira coisa de todas, a segunda coisa, eu pediria..., ah...sei lá..., muita paz entre mim e minha mãe, que nada mais de ruim aconteça e que tudo isso da minha cabeça vai saindo aos poucos, que eu não saia mais pra rua pra usar drogas; e a terceira coisa é pra eu continuar com o D. (namorado).

R: E se você ganhasse uma ilha, sozinha, solitária, uma ilha só tua, quem você levaria pra morar com você?

Pf: Minha mãe, minha avó, meu irmão e o D. (namorado), só, mais ninguém.

R: E quem você não levaria de jeito nenhum?

Pf: Meus tios e as amigas da minha mãe.

R: As sapatonas!!?

Pf: É.

R: Mas tem uma que você gosta.

Pf: É que eu gosto, que é a V. 


\section{R: Essa poderia ir?}

Pf: Essa poderia ir.

R: E os seus tios, por que você não levaria?

Pf: Porque é assim; quando eu saí da minha casa, eu fui na casa de cada tio meu, eles não me aceitavam, ou eles falavam que não tava, ou eles estavam mas falava que não, que ia sair, que não era pra mim ficar lá, que era pra mim ir pra casa da minha mãe e me virar com a minha mãe, que ela tinha que cuidar de mim porque ela que me pôs no mundo e eu sempre persistia, sempre persistia, quase todo dia eu ia, eles nada e nada, até o dia que eu não fui mais, eles não perguntam de mim e eu também não pergunto deles...

R: Se você ganhasse um premio grande na loteria, muito dinheiro mesmo, como é que você usaria o premio?

Pf: Eu compraria uma casa pra minha avó, uma casa pra mim e pra minha mãe, e uma pro meu irmão, e os outros dinheiros eu guardava pra mais tarde eu fazer minha faculdade, ajudava a pagar uma contas da minha mãe e da minha avó e ia viver.

R: Se você estivesse viajando num navio onde está a tua família toda e o navio começa a afundar, o que você faz?

Pf: Ah!; eu fico abraçada com a minha mãe e com a minha avó.

R: E se você pudesse ficar com uma só pra salvar, se você tivesse condições de salvar uma pessoa, que você escolheria?

Pf: Minha mãe.

R: Tua mãe. Como você se vê adulta?; de profissão, de casamento, como você acha que seria?

Pf: Eu acho que vai ser boa, eu me imagino indo trabalhar, deixando minha filha na escola, na creche, eu acordando meu marido cedo pra gente tomar o café e ir trabalhar, vai ser assim, eu acho.

R: Você queria ter uma filha só ou mais?

Pf: Não, eu queria ter um par, uma menina e um menino.

R: E aonde você gostaria de morar?

Pf: Ah!; eu ainda não pensei onde eu gostaria de morar, não tenho preferência.

$\mathrm{R}$ : E como é que você queria que fosse o seu marido?

Pf: Fosse um cara compreensivo, carinhoso, tivesse sempre do meu lado, tanto nas horas ruins como nas horas boas, toda hora que eu precisasse dele ele estivesse ali.

R: Você sabe como é que nasce um filho, como é que gera um filho?

Pf: Mais ou menos, minha mãe me explicou assim mais ou menos.

R: Fala o que você sabe em poucas palavras. Como é que um filho nasce, como é que forma o primeiro ovo.

Pf: Aí eu não sei, eu sei assim que um mês assim o feto vai crescendo e aí você tem que tomar mais cuidados, você não pode carregar peso, você não pode cair, você tem que fumar menos, se você usa drogas você tem parar, aí ele vai se desenvolvendo até a hora que ele nasce, aí tem vários cuidados, com o umbigo, pegar friagem, a hora de mamar. 
R: A relação sexual tem alguma coisa a ver com o nascimento de criança?

Pf: Tem.

R: Com relação a isso, você já falou.

Pf: Já.

R: Que você se sente um pouco constrangida, um pouco envergonhada.

Pf: Já falei.

\section{HTP e desenhos livres}

R: Hoje é 17 de janeiro de 2004, hoje eu queria que você fizesse pra mim alguns desenhos, não é pra eu ver o quando você é capaz de desenhar, é só pra você desenhar, pois assim você está se exprimindo, entendeu?; não é preciso caprichar, é apenas pra ver as coisas que te interessam, e depois que você fizer o desenho eu queria que você contasse umas coisas sobre ele.

Pf: Qualquer desenho?

R: Eu vou te pedir. Aí você tem lápis de cor, apontador, borracha, papel, o que você precisar, ta. Então o primeiro desenho que eu quero que você faça, é um desenho livre, qualquer coisa.

Pf: Como assim um desenho livre?

R: Livre..., eu podia pedir um carro, eu podia pedir uma borboleta mas não é um desenho livre, um desenho qualquer que você quiser fazer.

Pf: Pode ser uma flor?

R: Pode ser o que você quiser.

R: Me diga uma coisa; que flor é essa?; tem um tipo?

Pf: Não...

R: Aonde..., ela está em algum lugar especial?

Pf: Ta na ..., lá na praça do Jabaquara onde meu pai faleceu.

R: Na praça do Jabaquara onde seu pai faleceu. E o que ela representa, essa flor?

Pf: Meu pai.

R: Seu pai. Você tem uma lembrança bonita dele!!!?

Pf: É.

R: O que é uma flor pra você? O que representa uma flor assim pra você?

Pf: Harmonia, paz...

R: Você acha que na sua vida você gostaria que tivesse mais flores?

Pf: Gostaria.

R: O que você acha que é mais importante em uma pessoa?

Pf: A pessoa ser feliz, mostrar a felicidade que ela está sentindo, ela ser carinhosa, ser gentil, só...

R: Essas coisas..., você acha que você tem? 
Pf: Eu acho que eu tenho...

R: O suficiente?

Pf: Não, eu tenho pouco, mas ta bom assim pra mim.

R: Como é essa falta que você sente de seu pai?

Pf: Do jeito que ele me tratava, ele era super carinhoso, acho que se meu pai estivesse vivo eu não estaria aqui, não teria passado por tudo o que eu já passei, mas...

R: Você acha que algum dia essa falta pode ser substituída, por uma outra pessoa ou por uma outra coisa?

Pf: Não...

R: Não..., vai sempre ser uma falta...

Pf: Vai sempre ser uma falta.

R: Agora eu queria que você me desenhasse uma casa.

Pf: Casa?

R: Como você quiser...

Pf: Eu nem sei desenhar uma casa...

R: Acho que sabe sim, é só lembrar..., é fácil...

R: De quem é essa casa aí?

Pf: De ninguém...

R: Você pode inventar uma estória.

Pf:

R: Quem mora aqui dentro?

Pf: Uma família.

R: Uma família...Quem são as pessoas da família?

Pf: O pai, a mãe e os dois filhos...

R: Dois filhos..., dois meninos?; duas meninas?

Pf: Uma menina e um menino.

R: Que idade eles tem?

Pf: Um tem 7...

R: Quem tem 7?

Pf: A menina e o outro tem 4.

R: Qual o nome da menina e do menino?

Pf: Jéssica e Paulo.

R: E do pai e da mãe?

Pf: André e Jéssica...

R: Quantos anos eles tem?

Pf: A mãe tem 37 e o pai tem 39 
R: A onde estaria esta casa?

Pf: Não sei...

R: Inventa um lugar, que você ache que seria legal ela estar...

Pf: No Imirim.

R: I mirim..., o que é legal que lá tem?

Pf: Lá é bastante movimentado.

R: Movimentado..., muita gente..., e isso é uma coisa legal, que você gosta..

Pf: É.

R: E como é essa casa para as pessoas que moram dentro?

Pf: É bom...

R: Bom em que sentido?

Pf: Em todos..., em paz..., as crianças obedecem..., é bom.

R: Ela tem espaço bastante?

Pf: Tem.

R: E quem são essas duas que estão aqui na janela?

Pf: A menina e o menino...

$\mathrm{R}$ : Eles se dão bem?

Pf: Dão.

R: Aqui são 4 janelas..., o que tem em cada janela?

Pf: Qual parte da casa?

R: Isso.

Pf: Aqui são dois quartos, da mãe e do pai, da menina e do menino, aqui...pode ser...cozinha e aqui a sala.

R: Eles têm muitos vizinhos?

Pf: Tem.

R: E esses vizinhos são amigos; freqüentam a casa?

Pf: São.

R: E entre esses vizinhos cada um sabe da vida do outro?; ou cada um tem a sua...

Pf: Cada um tem a sua vida.

R: Tem a sua reserva...Por que o número 429?; tem algum significado?

Pf: Não..., é o número daqui.

R: É o número daqui, dessa casa.

Pf: É.

R: O que falta nessa casa?

Pf: Nada.

R: Nada..., você não colocaria nada aí dentro. E o que tem de bom nessa casa? 
Pf: Amor e carinho...

R: Agora eu queria que você me desenhasse uma árvore.

R: Do que é essa arvore?

Pf: De amora.

R: Amora...Aonde que ela ta?

Pf: No Jabaquara...

R: Aonde..., fala mais do lugar onde ela está.

Pf: É uma praça que tem lá, perto de uma creche que eu estudava...

R: É na mesma praça onde está a flor?

Pf: Não.

R: Não...O que representou essa árvore?; essa arvore existe de verdade ou é só na fantasia?

Pf: Existe.

R: Existe..., fez parte da tua infância?

Pf: Fez.

R: E o que ela te traz de lembrança?

Pf: Quando eu saía da escolinha e meu tio ia me buscar, eu sempre levava duas sacolinhas assim de Pão de Açúcar. Nós ia lá no pé e ficava a tarde inteira lá, enchia as sacolinhas, aí nós chegava em casa de noite, minha avó estava preocupada, nós falava: - Não, tava catando amora, vó. A gente ficava comendo, era todo dia assim.

R: Isso foi muito bom, uma lembrança boa...,você ficava bem perto do teu tio... Você se dava bem com ele?

Pf: Sim.

R: E o que são essas...

Pf: É os galhos...

R: São dois galhos que entram pra dentro... Você já viu na seringueira, aquela árvore que eles tiram borracha... Você já viu?

Pf: Já.

R: Como eles fazem pra tirar?

Pf: Não, já vi como a árvore é mas pra tirar não.

R: Você nunca viu quando eles cortam assim e parece com isso?; para sair o leite?; lembra?

Pf: Lembro.

R: Como você lembra, me conta.

Pf: Que eles cortam assim, pra sair o líquido né?; aí parece com esse daqui.

R: Você lembra da imagem?

Pf: Sim. 
R: E como está essa árvore de saúde?

Pf: Agora ela está velha já..., não tem nem mais amora nela.

R: Ela não dá mais fruto?

Pf: Não.

R: Como ela se sente velha?

Pf: As folhas dela ta caindo, já cortaram ela, cortaram um pouco dos galhos dela.

R: Qual o futuro dela?

Pf: Não sei...nem imagino.

R: O que ela precisa hoje?

Pf: Uma nova vida.

R: O que poderia dar uma nova vida pra ela?

Pf: Os homens parar de destruir acho que daria uma nova vida pra ela.

R: Tem homens que ficam destruindo ela?; de que jeito?

Pf: Eles cortam galhos, eles cortam todas as plantas aí depois quando eles vêem que ta crescendo eles vai lá e corta.

$\mathrm{R}$ : E aqui, isso aqui o que são?

Pf: As raízes.

R: As raízes...Então ta bom...Queria que você desenhasse agora, uma pessoa.

Pf: Não sei desenhar pessoa...

R: Não tem muita dificuldade.

Pf: Mas eu não sei desenhar uma pessoa...

R: Não precisa caprichar, faz alguma coisa que represente uma pessoa..

Pf: Eu não sei fazer...

R: Será que você não ta inibida demais?; você falou que não sabia fazer a casa e fez...

Pf: Mas a pessoa eu não sei fazer...

R: Uma cabeça, os braços, as pernas...

Pf: Não sei fazer...

R: Então me faz um outro desenho livre assim qualquer...

Pf: Um desenho livre.

R: É.

Pf: Qualquer desenho?

R: Qualquer, que nem você fez no primeiro. Qualquer desenho, não precisa ser igual ao que você fez.

Pf: Vou fazer um desenho que nós fazia quando era pequena.

Pf: Pronto. 
R: O que é isso?

Pf: Um coração com duas asas, uma coroinha.

$\mathrm{R}$ : $\mathrm{E}$ isso aqui o que é?

Pf: Um coração partido.

R: O que partiu esse coração?

Pf: Quando eu era pequena, depois que meu pai morreu, quando eu tinha 7 anos, eu falava que meu coração estava partido assim, por causa do meu pai e que nunca ia se concertar, aí minha mãe pegou e fez um desenho assim.

R: Representa a perda do teu pai pra você.

Pf: É.

$R$ : $E$ isso daqui o que é?

Pf: Não é nada, só um enfeite.

R: Enfeite..., e essas asas desse coração vão levar ele pra onde?

Pf: Pro céu.

R: Esse coração tem dono?

Pf: Tem, é meu.

R: É o teu...O que esse coração precisa?

Pf: Do meu pai de volta mas eu não vou ter, né, fica assim mesmo.

R: Não vai ter solução...E essa auréola daqui de cima, o que ela representa?

Pf: Um anjo que meu pai virou.

R: Teu pai ta muito misturado com você, né...

Pf: Ta..., bastante.

R: Ta bom..., só que agora eu vou ser chato e vou insistir pra você desenhar uma pessoa que eu vi..., ó aqui que você desenhou essas pessoas...

Pf: Ah...mas aí é fácil.

R: Mas eu não estou pedindo pra você fazer um grande desenho, eu pedi pra você fazer uma pessoa, e isso é uma pessoa...

Pf: Mas eu não sei fazer uma pessoa...

R: Pode ser assim mesmo.

Pf: Eu não sei fazer uma pessoa, se eu fizer não vai se ninguém.

R: Então faz a representação de uma pessoa que não é ninguém.

Pf: Não vai ter significado nenhum.

R: Ta bom..., mas já é alguma coisa...

Pf: Não significa...

R: Significa um nada.

R: Essa pessoa é homem ou é mulher?

Pf: Mulher.

R: Mulher..., ela tem nome? 
Pf: Não, não é ninguém...

R: Qual a importância das pessoas na tua vida?

Pf: Depende das pessoas, depende muito.

R: Depende do que?

Pf: Das pessoas..., a minha mãe, a minha mãe é importante pra mim, minha avó, só...

R: Mais ninguém...Como você se sente no teu intimo do lado das pessoas?

Pf: Bem.

R: Mas elas quase não existem pra você.

Pf: Não, não são todas, são só algumas...

R: Quem são as que não existem?

Pf: Meus tios pra mim não existem.

R: Você matou eles todos dentro de você...Essa pessoa está saudável ou está doente?

Pf: Saudável.

R: Falta alguma coisa pra ela?

Pf: Não.

R: E ela tem alguma coisa de bom?

Pf: Tem bastante.

R: O que?

Pf: Carinho, compreensão...

R: Agora o ultimo, prometo que não encho mais..., agora você vai me fazer uma pessoa do sexo oposto.

Pf: Ah! não (risos constrangidos), não...

R: Vai, não é tão ruim assim...Acabou? Quem é esse sujeito?

Pf: Ninguém.

R: Tem nome?

Pf: Não, é um boneco.

R: É um boneco. Ele nem vida tem?

Pf:

R: Do que é esse boneco, de pano, de madeira, de ferro...

Pf: De pano.

R: Esse boneco foi de alguém?; ele está numa loja?; ele está longe?

Pf: Está numa loja.

R: Como é a loja?

Pf: De brinquedos.

$\mathrm{R}$ : E quando você viu ele lá?

Pf: ... sei lá... 
R: Ele é bonito ou é feio?

Pf: É feio.

R: Você queria um desse pra você?

Pf: Não.

R: Então é isso. Muito obrigado P. por enquanto. 


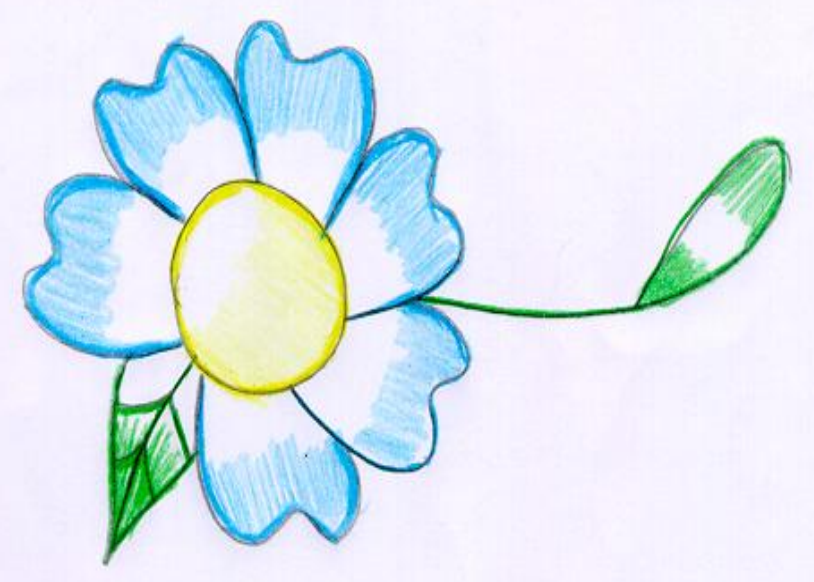




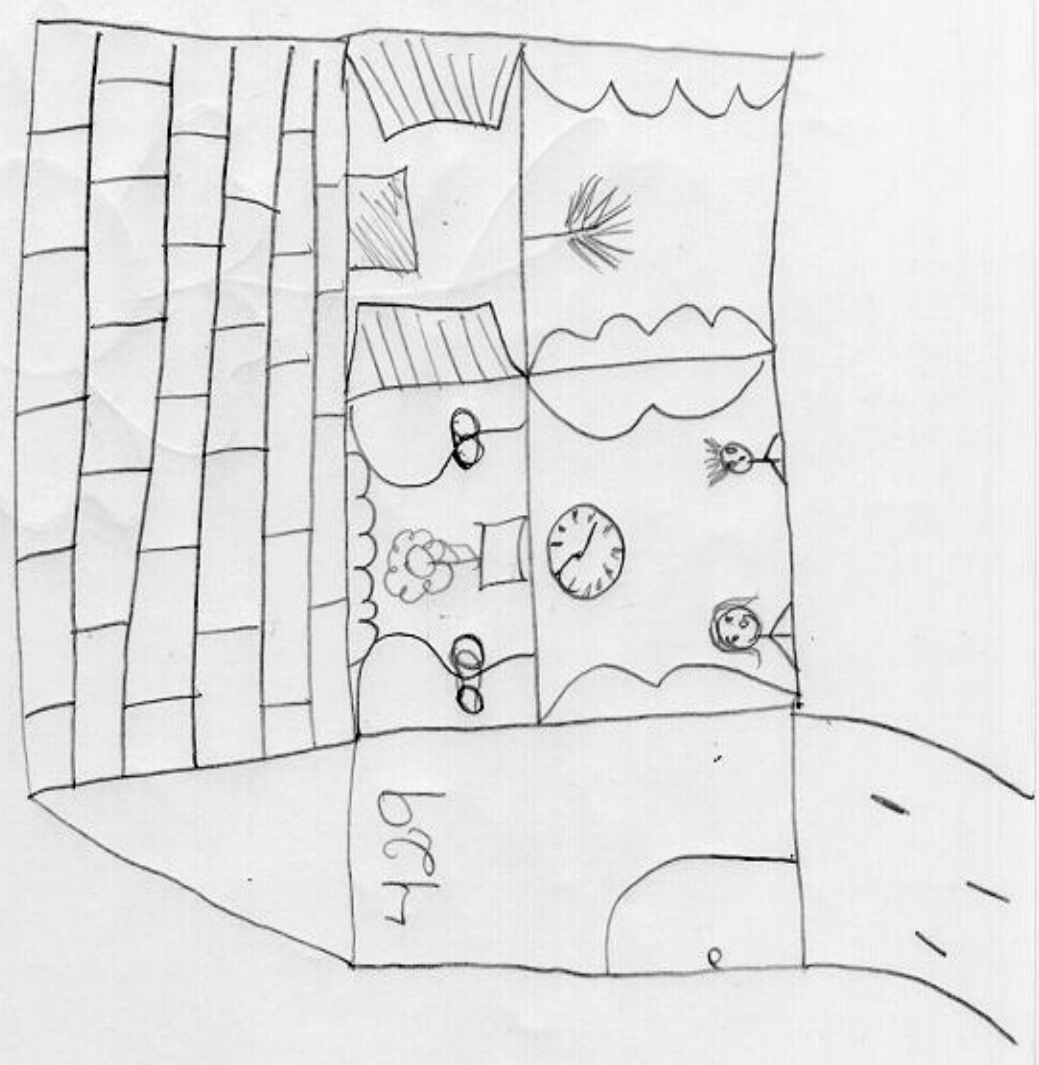




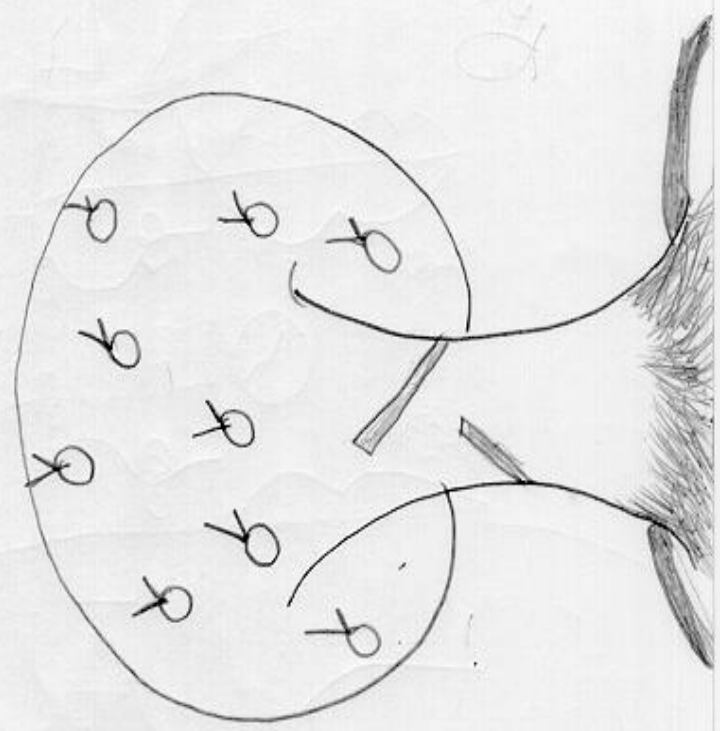




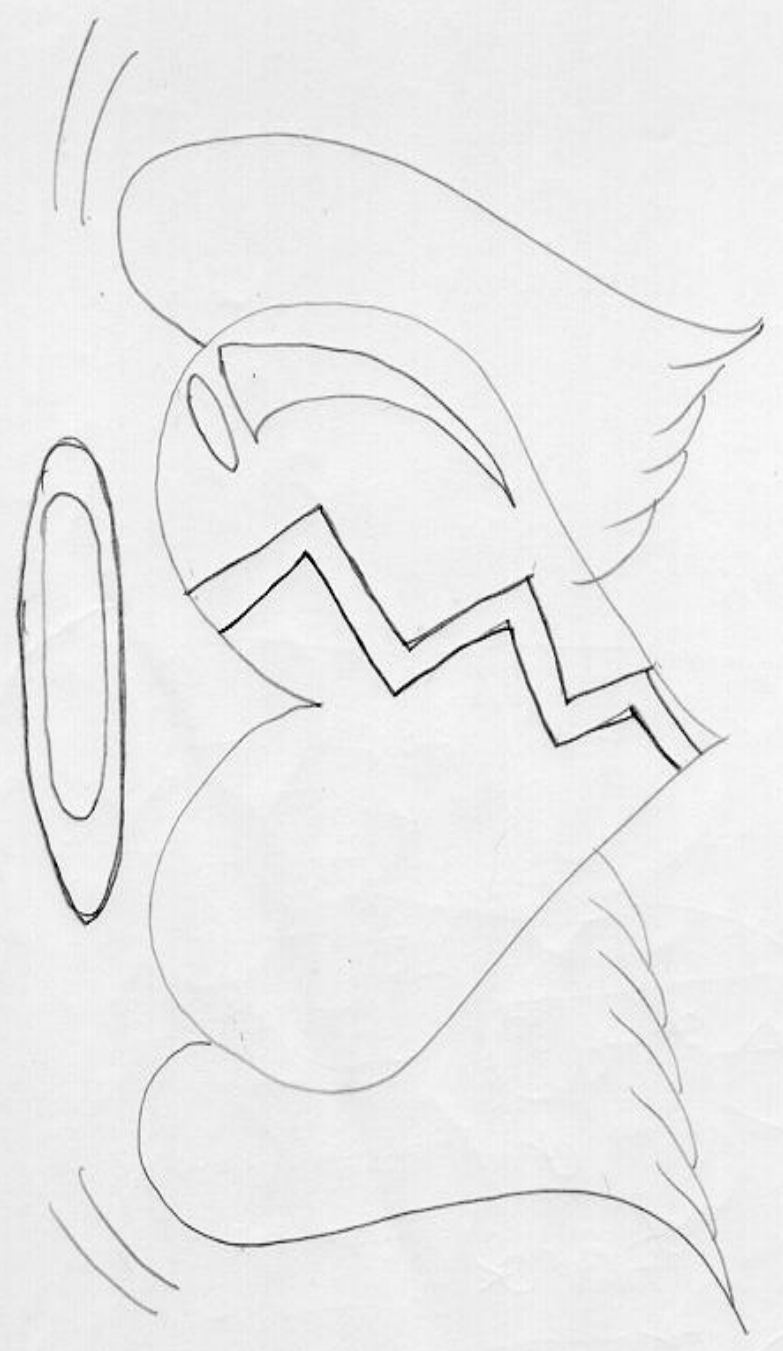


Q 
$\theta\{r$ 


\section{TAT}

R: Eu vou te mostrar uns desenhos e eu queria que você me contasse uma estória sobre esses desenhos. Da tua cabeça, sem se preocupar que tem de ser lógico, certo, coerente; como se fosse uma estória de um livro, como se você estivesse inventando, entendeu, como você quiser...Vale colocar fantasia, gente pode voar..., então vamos lá.

Prancha 1, me conta uma estória sobre o que você vê aqui.

Pf: É um violino que ele ta olhando?

R: É o que você quiser, é o que você ta vendo e o que você acha que te parece, agora eu queria que você falasse mais alto um pouquinho por causa da gravação.

Pf: Ta bom. Se fosse pra eu tirar uma estória dessa imagem eu tiraria assim: que o menino está um pouco pensativo olhando pro violino dele, ele não está com muita disposição de tocar violino, e tal, ta um pouco triste pelo fato que aconteceu...

R: O que aconteceu antes?

Pf: Ah!..., ele discutiu com a mãe dele, foi fazer aula de violino e não ta muito disponível que ele ta pensando, ele ta errado, ta pensando no erro que ele fez e não ta conseguindo fazer a aula.

R: Que erro que ele fez?

Pf: A professora reclamou da escola pra mãe dele, e ele ta meio pensativo.

$\mathrm{R}$ : E como vai terminar essa estória?

Pf: Ah!..., eu pra inventar estória é um caos...

R: Não se preocupa com a lógica, inventa do jeito que você achar...põe a fantasia pra funcionar, como se você estivesse sonhando...

Pf: De ele ficar o dia inteiro sem fazer nada com o violino, quando chega em casa ele conversa com a mãe dele e fala que não vai mais acontecer isso e aí no outro dia ele vai pra escola e ele melhora, aí faz a aula de violino dele com mais disposição e aí fica tudo bem.

R: Prancha 3MF, o que você vê aqui?

Pf: ... É uma mulher ou é uma menina?

R: É o que você quiser.

Pf: Eu vou por assim que ela discutiu com o marido dela, está chateada, ta saindo..., não ela saiu de cabeça quente, agora ta voltando arrependida da discussão que aconteceu, ta chorando, ela ta voltando e ela conversa com o marido dela, eles vão conversando e aí vão conversando, conversando e se entendem.

R: Qual foi o motivo da discussão?

Pf: O motivo da discussão foi por ciúmes.

R: Ciúmes de quem? 
Pf: Da mulher que trabalha com ele.

R: Ah!; ... a mulher sente ciúme do marido por causa da mulher...

Pf: Que trabalha com ele e aí ela chamou ele pra almoçar e ele foi almoçar com a secretária, que era a mulher e aí quando ela chegou discutiu, aí ela saiu de cabeça quente, aí ela voltou chorando, conversou com o marido dela, aí conversaram, conversaram e aí voltaram ao normal.

R: E ela tem razão de ter ciúme do marido ou não?

Pf: Não..., eu acho que...

$\mathrm{R}$ : O marido é fiel ou ele engana ela?

Pf: Não..., eu acho que nem todos são fiéis, mas já que ela ta com ele ela deveria dar um voto de confiança, que as vezes eles vão conversar sobre trabalho, não é nem o que ela ta pensando, acho que rolou de bobeira.

R: E como é que terminaram? Ah! você falou que...

Pf: Eles conversam e fica tudo bem...

R: Prancha 7RH; o que você vê aqui?

Pf: (Murmúrio).

R: Fala alto.

Pf: Qualquer coisa que tem a ver com o pai aqui?

R: Você fala do jeito que você quiser, não tem certo e errado nisso.

Pf: Ta. O pai ta conversando com o filho porque ele ta meio deprimido e aí eles estão conversando, porque ele ta deprimido...

R: Quem ta deprimido?

Pf: O filho dele.

R: O filho.

Pf: O pai ta dando uns conselhos pra ele, que ele ta falando assim que ele ta com muito problema na empresa que ele trabalha...

R: Quem ta com problema?

Pf: O filho dele, ele ta falando pro pai que ele ta com muito problema, que ele ta chegando em casa muito tarde, que a mulher ta desconfiada que ele ta saindo com outra, aí o pai dele falou pra ele sentar e conversar com a mulher dele, falar que tem muitos problemas na empresa pra resolver, e que não tem nada haver o que ela está pensando, e com calma o tempo passa e vai ficar tudo bem.

R: E como esta situação chegou aí nesse momento? Antes deles estarem aí nesse momento o que aconteceu?

Pf: Ah!..., ele tava na empresa, aí ele tava com a cabeça muito quente, queria pedir demissão, na hora do almoço ele saiu e foi direto ao pai dele, pediu pra ajudar ele, dar um conselho pra ele, o que é melhor pra ele fazer...

R: E o que vai ser disso tudo?

Pf: Aí ele vai chegar em casa, vai conversar com a mulher dele, vai explicar os problemas que ta acontecendo na empresa, aí quando ele chegar no serviço dele ele vai conversar com o chefe dele e aí vai ficar tudo bem... 


\section{R: Prancha 8RM. O que você está vendo aqui?}

Pf: Uma mulher né, um cara deitado, mas não parece ser médico, ...é dois caras seqüestraram um homem né..., que eu to imaginando assim, seqüestraram um homem e a mulher parece ser a cúmplice dos dois e o cara ta cortando ele..., só...

R: Como é que chegou nessa situação...

Pf: Eu acho que o cara tava..., acho que o cara tinha uma fazenda e aí eles foi catar o cara pra catar alguma coisa na fazenda, então eles cataram o cara, a mulher dele viu tudo, eles cataram o cara e agora estão cortando a barriga do cara.

R: Estão cortando pra que?

Pf: Ah!..., pra matar.

R: Pra matar. E como é que vai terminar?

Pf: Eles matam o cara, escondem o corpo dele e aí conforme o tempo vai passando, as pessoas vão sentindo falta dele, e essa mulher todo dia passa lá e as pessoas começaram a desconfiar dela, aí vão investigando, aí acham o corpo dele, aí a mulher acaba sendo a culpada e aí ela vai presa, e aí fica tudo bem, aí eles contam tudo pra família do cara e aí fica tudo bem.

R: Ela vai presa?; e os cúmplices?

Pf: Os cúmplices fugiram e ninguém consegue achar.

R: E o corpo?

Pf: O corpo acharam e aí fizeram o enterro, aí a família do cara que morreu vai receber indenização...

\section{R: Prancha 9RH. O que você vê aqui?}

Pf: Vamos supor que de manhã eles acordaram, 5 horas da manhã, trabalharam, na hora do almoço eles comeram e agora estão descansando, depois eles vão, depois de um descansinho, eles vão levantar e vão trabalhar mais ainda, e aí de noite vai cada um pra sua casa, cuidar da sua família, cansados e vão deitar e dormir.

R: Eles são amigos?

Pf: É eles são amigos e eles estão tirando um descanso, pra depois eles começar a batalhar de novo.

R: São todos iguais ai. Todos são empregados

Pf: São...

\section{R: Prancha 13HF. O que vocêvê aqui?}

Pf: Ah!; ...essa prancha é meio complicada..., ah eu acho que eles tiveram..., vamos supor que eles tiveram uma relação, depois eles tiveram uma pequena discussão o marido foi e matou ela, agora ta arrependido e não sabe o que fazer.

R: E a discussão foi por que razão? 
Pf: Porque tava rolando um clima, um clima, aí chegou e ela não quis nada com ele, disse que não gostava mais dele, não queria mais ficar com ele e aí eles começaram a discutir e aí ele se irritou, ficou revoltado porque ela não queria mais nada com ele e ele pegou e matou ela, e agora ta arrependido, não sabe o que fazer...

R: Como é que ele matou ela?

Pf: Ah!..., enforcada.

R: Enforcada. E como vai terminar essa estória?

Pf: Acho que ele vai chamar a polícia, vai se entregar e vai cumprir a pena e vai ficar tudo bem, a mulher vai ser enterrada e aí vai ficar tudo bem. E ele nunca vai retirar esse peso da cabeça...

\section{R: Prancha 14.}

Pf: Eu vejo aqui uma mulher, acabou de sair do serviço dela, ta meio pensativa nos problemas, sentou lá na janela, ta pensando um pouco, olhando pro céu, aí depois ela vai descansar bastante, pensa como vai ser o dia dela amanhã, aí ela acorda e ocorre tudo bem...

R: Ela ta na casa dela?

Pf: Na casa dela.

R: Ela mora com quem?

Pf: Mora ela e os filhos dela e o marido dela.

R: Ela trabalha com o que?

Pf: Ela é secretária.

R: E que problemas estão ocupando a cabeça dela?

Pf: As contas pra pagar, pouco salário ela vai receber, são muitas contas, a escola, a perua do filho dela...

R: E aí ela vai dormir, vai acordar e o dia seguinte vai ser como?

Pf: No dia seguinte ela vai estar um pouco com a cabeça fria, vai trabalhar..., só...

R: Prancha 16. O que você vê aqui??

Pf: Nada (risos).

R: Põem uma estória aí, pode por o que você quiser.

Pf: (risos).... Não tem o que por aqui, só a tela, branca...

R: Então imagina, como se fosse uma tela de cinema e de dentro da tua cabeça projeta aí um filme e conta.

Pf: Ah!..., eu não tenho o que por aqui...

R: Qualquer coisa.

Pf: Mas eu não tenho o que por aqui...deve ser meio difícil você ficar pensando..., quando está em branco, agora se já tem uma imagem pra raciocinar aí sim, ....aqui não tem nada... 
R: Se você fosse uma contadora de estórias e tivesse uma folha em branco, o que você ia por nessa folha?

Pf: Ah..., não sei, não sei.

R: Ta, então P. hoje a gente termina, obrigado. 


\section{ANEXO 5}

\section{Sujeito Pm. (masculino)}

\section{Primeira entrevista:}

$\mathrm{R}$ : Ta com sono?

Pm: Não (rindo).

R: P., me conta um pouquinho de sua vida, primeiro quando você nasceu?

Pm: Eu nasci em março de 1984, aqui em Osasco, morei em....(alguém bate à porta) pausa

R: Nasceu em março de 1984.

Pm: É.... morei com minha mãe até uns dois anos, ela foi embora aí eu fui morar com minha avó lá no interior, morei em Catanduva até os 7 anos de idade aí ela faleceu, aí eu voltei para São Paulo, aí chegando aqui em São Paulo eu fui morar com minha tia né, só que aí não dava assim muito certo, que ela bebia um pouco sabe e a gente não se dava bem, não que a gente brigasse, mas acho que faltava alguma coisa sabe, um diálogo, alguma coisa, ela vivia assim no mundo dela e tal aí eu fui morar na rua, eu fui morar na rua, eu tinha uns 11 anos de idade, aí de início eu fiquei morando ali em Pinheiros, ali perto do Largo da Batata sabe?!; tinha uma casa lá abandonada e eu ficava dormindo assim na frente, fiquei dormindo lá uns 6 meses, aí depois eu comecei vim aqui pra cima, pra Rebouças, comecei a conhecer o pessoal, aí conheci o projeto lá embaixo.

Pausa, alguém abre a porta e se desculpa, a porta é trancada.....

R: Bom acho que agora não vamos ter mais interrupção, aí você tava contando que tava no Largo da Batata, na casa e conheceu o pessoal...

Pm: É eu comecei a andar aqui por cima....comecei também a conhecer outros lugares, ficava andando, assim é mais ou menos isso.....

R: Escuta...., me fala do que você lembra de quando era pequeno, como era sua casa, quando você estava em Osasco!

Pm: Eu lembro...

R: Se você puder falar do que você lembra, com mais detalhes que você puder.

Pm: Eu só lembro assim de dois acontecimentos, que foi duas vezes que eu fui visitar meu pai na cadeia, a única coisa assim que eu lembro, que de resto assim eu não..., lembro assim como era a casa e tal, assim eu e as minhas irmãs brincando, algumas brigas que aconteciam, isso você lembra mas...

R: Então conta....

Pm: De resto....eu lembro assim....

$\mathrm{R}$ : Como era sua casa? 
Pm: Era uma casa tipo assim verde, sabe, tinha um quintalzão, tinha uma arvores (rindo), aí todo dia minha mãe ficava dormindo assim até umas 10 horas e eu e minhas irmãs acordava de manhã e ia brincar lá, era legal.

R: Arvore de fruta?

Pm: É..

R: E quantas irmãs?

Pm: Eu tenho duas irmãs.

R: Mais novas?

Pm: Mais velhas...

R: E fala delas assim, como é que era, como vocês se davam?

Pm: Bom, a mais velha ela chama C. f. e ...a gente se dava super bem assim, tanto que até hoje,ta certo que a gente tirando este curto período assim que eu fiquei em casa até os dois anos a gente não conviveu muito sabe, se via assim de vez em quando .... às vezes...que nem depois eu....

R: Porque se via de vez em quando?

Pm: Por que assim quando minha mãe foi embora, ela e minha outra irmã foi morar com uma tia minha e eu fui morar com minha avó, então a gente ficou uns nove anos sem se ver sabe..

R: Mas quando vocês estavam na casa com sua mãe vocês ficavam juntos sempre ... até sua mãe ir embora?

Pm: É, então aí quando a gente voltou a se ver a gente se dava bem e tal....eu e ela e a minha outra irmã do meio ela já era mais (rindo) era mais briguenta, a gente se dava bem só que discutia bastante assim, também a gente começou a se conhecer mais depois de grande, depois quando eu tinha 10 anos, quando eu fui morar com esta minha tia.

R: E na época em que vocês eram pequenos, que vocês vivam juntos..., como é que..., fala um pouco mais das suas irmãs, quando vocês viviam juntos, o que vocês gostavam...

Pm: A do meio eu não lembro muito assim...dela, quando a gente era pequeno, a mais velha eu já lembro mais que ela ficava com a gente e tal porque a minha mãe saía para trabalhar..., ela era uma pessoa assim legal... só que um pouco chorona (rindo) dessas pessoas bem sentimental...., ela era legal.

R: Ela chorava por que razão..?

Pm: Porque é assim, porque ela já era grande, assim quando eu era pequeno ela já era um pouco maior assim acho que quase

Interrupção, alguém bateu na porta.

Pm: Então....ela já entendia algumas coisas assim que..., a gente ainda não entendia, algumas coisas que sei lá....acontecia...que, bom eu nunca vi mas diziam muito...meus parentes assim por parte de mãe...que meu pai e minha mãe brigava bastante, ......aí......

R: Você não lembra....

Pm: Não lembro...

R: As pessoas te contavam. 
Pm: É e o pior que nunca dá para você saber a realidade o que acontecia, porque eu vivia uma época da minha vida com minha avó e logicamente que ela não ia falar que meu pai brigava que batia na minha mãe, em contrapartida eu vivi uma época da minha vida com a família da minha mãe, eles nunca ia falar que a minha mãe brigava, procurava não sei o que, sabe..., então até hoje eu não sei o que aconteceu mas dizem que meu pai batia muito nela...bom eu não acredito né (risinho)....

R: Você não acredita....

Pm: Não..., porque assim, eu só tenho duas lembranças dele e essas duas lembranças, sabe quando você tem uma visão de uma pessoa, você conhece uma pessoa assim boa, por mais que os outros fica falando que aquela pessoa é ruim, aquela pessoa é ruim, se você conheceu aquela pessoa de um jeito, aquela sua visão nunca vai mudar.

R: E você estava falando de sua irmã, que ela reclamava, que ela chorava, você começou a contar, então.... continua...

Pm: Então eu não sei bem por que ela era assim, eu acho que ela, que assim...o meu pai era envolvido assim com o com o crime assim sabe.

R: Pode falar....isto é entre nós.......

Pm: Então acho que ela...sei lá...deve ter presenciado alguma coisa que.... presenciava né.... alguma coisa que afetou, afetou até hoje um pouco ela assim, ela é uma pessoa assim bem....sabe...., ela é uma pessoa assim emotiva, que qualquer coisa fica abalada, tanto que uma vez brincando, eu acho que eu tinha uns......assim foi uma vez que eu fui visitar ela eu acho que eu tinha uns 6 , 5 anos de idade, assim a gente brincando assim eu falei que eu ia matar ela só que ela ficou assim, putz, ela ficou quase 5 anos sem falar comigo.

R: E foi só uma brincadeira.

Pm: É brincando assim, não sei o que ela tinha falado pra eu não fazer e eu falei assim: vou te matar (rindo) aí ela, não pó!!!; ela ficou doente, teve que ir no médico.

R: É mesmo e, você acha que foi só por causa desta brincadeira...

Pm: É, só dessa palavra, não sei o que aconteceu né...

R: Mas você acha que foi isso que desencadeou....

Pm: Foi por que assim...se alguém fala alguma coisa pra ela neste sentido...ela tipo entra em depressão sabe.

R: Sei e ela ta...., onde é que ela ta...?

Pm: Ela mora sozinha......

R: Você fala com ela.....?

Pm: Não eu não falo com ela faz uns dois anos, desde que minha tia faleceu....

R: Ela mora onde?

Pm: Mora no Taboão....

R: Você sabe onde ela mora?

Pm: Sei...

R: E você não tem vontade de procurá-la... 
Pm: Não....só que.....eu e minha família assim em geral....a família inteira....não tem assim esse vínculo assim de um visitar o outro, cada um vive..., é chato né mas cada um vive assim mais no seu mundo particular, tanto que até quando eu estava lá, nunca, sabe o que é um feriado assim, alguma coisa, nunca tinha aquela união fraternal, cada um ficava na sua....

\section{R: Quando você estava aonde?}

Pm: Quando eu morava na casa de minha tia...

R: Ah!; na sua tia...

Pm: É eu digo assim minha família por parte de mãe, é como se nem fosse parente sabe, êh.. êh...

R: Meio distante...

Pm: É bem distante.

R: Essa tia que você foi morar é a mesma que acolheu as suas irmãs?

Pm: (confirmou com a cabeça..)

R: E quanto tempo você passou lá com sua tia. Conta um pouco como era com a sua tia....

Pm: Ah!; era assim, era um pouco pesado assim porque lá só tem mulher sabe, só tinha eu e meu padrasto de homem então era a gente que trabalhava, então era um pouco pesado, tinha que trabalhar e tal, trabalhava na feira sabe, montando barraca...

R: Qual a idade que você tinha?

Pm: Ah eu comecei ir pra lá com 10 anos de idade...

R: E aí já te pegaram pra ajudar nas despesas....

Pm: É.. êh...êh....

R: O que você achava disto?

Pm: Bom eu não achava ruim, eu achava legal, né que tal, às vezes era cansativo que não dava pra você conciliar assim que nem, eu...na época eu tava na 4a série, não tinha como eu estudar à noite certo, aí eu ia trabalhar, chegava em casa assim sabe...todo dia eu chegava atrasado na escola (risos), entrava 2 e 40 da tarde, foi o melhor horário assim que eu achei...., aí eu chegava em casa duas e meia só era o tempo de eu tomar um banho rapidinho sabe e sair....., eu achava que era um pouco pesado isso, mas..... mas era bom.

R: Você achava que os seus tios preferiam que você trabalhasse, era mais necessário que você trabalhasse do que estudasse.

Pm: Bom....era mais necessário mesmo né, mas ela sempre cobrava a escola, ela nunca falou assim...Eu no meu ponto de vista achava mais necessário, só que ela nunca chegou assim: - "Não você tem que trabalhar, você não pode estudar, sabe, ela sempre falava: - "Não você tem que ir para a escola, você pode trabalhar se você quiser mas tem que ir pra escola, é o fundamental, só que naquela época também nem gostava muito de escola, então já tinha aquilo como uma carga sabe, por não gostar muito e por não ter essa conciliação de horário.

R: Então você também tinha o desejo de fazer o seu trabalho meio que pra deixar de estudar...

Pm: É (rindo). 
R: E como era com o seu tio, né, o marido de sua tia.

Pm: Não, é...., então...

R: É com ele que você ia pra feira né?

Pm: Não eu ia sozinho.

R: Ah!; sozinho, mas quem..., você falou que eram dois homens...

Pm: Então só que ele trabalhava em uma coisa e eu trabalhava em outra...., ele trabalhava de pedreiro...., ele era uma pessoa assim sabe.....legal...., nem legal nem ruim, aquela pessoa que fica no canto dela não conversava com ninguém êh...êh....., assim conversava, mas ele nunca tomava a frente de nada....

R: O que você achava dele...

Pm: Eu achava uma pessoa legal, ele era bem controlado assim.....

R: Quanto tempo você ficou lá na sua tia?

Pm: Fiquei quase dois anos, um ano e meio, assim....

R: E como é que você sentiu lá que você foi se afastando até chegar a sair para a rua?

Pm: Não..., não ..., é assim...., eu acho que...eu tinha vivido bastante tempo com a outra parte da minha família sabe, eu tinha um estilo de vida diferente, assim, sabe quando você está acostumado a conversar com a pessoa sabe, minha avó, a gente conversava assim, aí tipo eu fui morar..., não que não tinha conversa, tinha conversa mas nunca era aquela coisa, você conversava uma vez por ano, mesmo você morando do lado da pessoa vendo a pessoa todo dia não tinha aquele afeto sabe..., era como todo mundo fosse estranho.

R: Sei, e isso ..., como é que você sentia?

Pm: Ah!; eu não sentia bem né, você não se sente assim à vontade.

R: E com as tuas irmãs, elas não estavam lá?; não tinha uma relação mais próxima?

Pm: Então, nesta época uma morava lá e no mesmo ano em que eu fui pra lá ela também foi embora assim..

R: Qual que foi embora, a mais velha ou a mais nova?

Pm: É a mais velha e a mais nova, morava lá, só que a mais velha ela trabalhava, dormia no emprego só ia lá de fim de semana, e a do meio ela saiu de lá, fugiu, sei lá, até hoje eu nunca mais vi ela...

R: Não teve mais notícia dela....

Pm: Não, faz nove anos... que eu não vejo ela.

R: E como é que foi acontecendo de você ir pensando em sair.....

Pm: Ó ...eu não..., eu não pensava em sair de lá, não pensava, ....só que assim foi do nada, um dia eu decidi, eu tava trabalhando e eu falei assim, era numa sexta-feira, eu falei não, não vou mais pra casa (rindo), sabe eu decidi assim, eu não.....

R: De repente...

Pm: É de repente.

R: Mas você pra chegar nesta idéia, o que aconteceu, você viu outros meninos, você conversava com alguém..... 
Pm: Não, não conversava com ninguém, isso daí nunca passou pela minha cabeça...., a primeira vez que eu pensei nisto eu fiz, sabe....

R: E tinha acontecido alguma coisa antes?

Pm: Não...

R: Que te aborreceu, ou alguma coisa mais forte....

Pm: Não...

R: Nada de especial...

Pm: Tanto que assim, eu pensei assim, eu vou ficar uns dias assim fora de casa depois eu volto...., eu acho que eu só queria um pouco ficar sozinho, assim sabe...

R: É...., você resolveu isso sair do trabalho, da escola e...., saiu sem dinheiro, sem roupa, sem nada...

Pm: É (rindo) só com a roupa do corpo.....

R: E aí você foi pra onde?

Pm: Aí eu vim aqui pra Pinheiros né, aí eu não sei se você conhece o Habib's ali da Pedroso....

R: Mais ou menos...

Pm: Aí eu fui lá e fiquei tomando conta de carro né, a noite inteira, aí no outro dia eu falei assim.. , sabe de uma coisa, não que..... era assim, eu não ia sair, eu ia ficar a noite assim e no outro dia ia embora, aí depois no outro dia eu pensei assim: Não...., acho que eu não vou mais para casa, sabe...vou viver por si só....

R: Quer dizer que você. ficou tomando conta de carro, bom alguma coisa foi boa pra você resolver ficar lá....

Pm: Não, ...não, eu acho que só o fato assim de você não ter, sei lá, aquela cobrança sabe, que numa casa você tem aquela cobrança quanto a horários e tal..., quando você é mais novo assim, você porque isso porque aquilo, porque eu não posso sair com os meus amigos, você fica naquela porque eu não posso jogar bola, porque eu tenho de trabalhar sabe, sabe você fica colocando as coisas na balança, porque eu tenho de ir pra escola e porque eu sou obrigado a ir pra escola e muita gente não é, sabe.... ficava pensando nisso....

R: Ficava questionando ...., queria um pouco de liberdade. E como é que foram os seus primeiros dias na rua?

Pm: Ah..., o primeiro ano, o primeiro ano...., é aquela coisa...., imagine só você não conhecia nada, não ter nada, você não saber pra onde você vai, como eu vou fazer isso, como eu vou comer, nossa, passava fome pra caramba....

R: Você tinha 10 anos e meio...

Pm: É

R: Mas e aí, como é que você foi chegar em Pinheiros? Você. já sabia...

Pm: Então, eu já sabia porque eu vinha fazer uma feira aqui de sábado, então eu conhecia mais ou menos, só ali aquela regiãozinha, não conhecia aqui pra cima, só que eu sempre tive uma vontade assim de conhecer novos lugares, então eu catava o ônibus e ficava, ia pra um lugar ia pro outro, ficava fazendo este itinerário aí, 24 horas (riso)... 
R: Mas você foi parar direto no Habib's porque você já tinha visto que dava pra guardar carro lá ou foi...

Pm: Não, fui descendo assim que nem..., aí eu saí da feira lá, foi num sábado, em outubro, acho que 15 ou 16 de outubro de 95, daí eu fui descendo a rua assim e vi o Habib's, e aí vi os carros assim e disse será que dá pra tomar conta de carros aqui, tanto que aconteceu uns negócios legais lá que nem o pessoal de lá eles não gostava que ninguém, sabe, os moradores, ninguém pode ficar tomando conta de carro aqui, porque os moleques que vem tomar conta de carro é folgado e não sei o que, daí tipo eu fui fazendo amizade, ajudava a limpar um pouco a praça, que tinha uma pracinha, tem né uma pracinha, aí eu dava força prum tiozinho que ficava limpando a praça, até falou: “- Não, pode ficar tomando conta de carro"; aí eu fiquei uns 4 meses lá, tomando conta de carro.

R: E tinha outros meninos que tomavam conta de carro?

Pm: Não, na época.... não tinha.

R: Era só você..., e como é que você fez pra dormir, onde você foi dormir, onde você comia.?

Pm: Ah!; tipo assim, quando eu tinha dinheiro, assim no começo, antes de eu descobrir como é que era na rua e tal, quando eu tinha dinheiro eu comia, quando eu não tinha eu não comia, então aí eu ia prum lugar e tomava conta de carro, ou ia pra feira, fazia uns carretos...

R: Passou fome?

Pm: Oh!!.....Fiquei assim uns 4 dias sem comer nada...

R: Sério..

Pm: É...

R: Isso logo no comecinho....

Pm: No começo, aí depois de um tempo você vai descobrindo assim sabe, você tem contato com outras pessoas com a mesma situação, aí que nem, aí eu conheci o T.m. sabe!? O T.m. que ficava aqui? (me perguntando), que era o marido da E.f., aquela grávida...

R: Sei

Pm: Então aí, então aí a gente se conheceu, desde criança né, ele tinha 11 anos e eu tinha 10, a gente se conheceu assim e eu conheci outro colega meu o Maurício, a gente ficava assim: Vamos catar rabeira de trem e tal, aí nós ficamos um tempo nessa só surfando no trem, em cima, em baixo......

R: Você viu gente morrer lá no trem..

Pm: Não..., só um colega meu que caiu uma vez e ele quase morreu, ele ficou dois dias lá na linha....

R: Como?

Pm: É assim, só que este dia eu não tava, ele tava lá encima do trem aí ele caiu, aí ele machucou aqui (mostrou o queixo), sabe aqueles parafusos da linha, entrou bem aqui e machucou ele tipo todo e ele não conseguia andar, aí ele foi se arrastando assim até estas pontes, sabe, ficou lá debaixo da ponte do trem, ficou lá uns dois dias, aí....

R: Aí se recuperou...

Pm: Acho que deu uma melhoradinha ou alguém passou e viu, não lembro.... 
R: E o que você apreendeu pra sobreviver, você tava dizendo assim que no começo era mais difícil né...., você deve ter apreendido alguma coisa....

Pm: É....essas coisas você vai apreendendo assim, quando você ta com fome que lugar você vai pra pedir uma comida, sabe....

$\mathrm{R}$ : E roupa, como é que você se virou....?

Pm: Ah!; no começo assim passava frio direto né...(risos), ó só de bermuda e camiseta..., por isso que até hoje, hoje em dia assim eu nem uso blusa, êh, êh, eu já peguei cada friagem...

R: Mas P. me fala uma coisa, você vivendo essa situação difícil assim, naquele tempo você não pensava em voltar para casa....

Pm: Nãoooo.....

R: Mesmo a situação sendo difícil, você achou...., preferiu ficar na rua....

Pm: Ó, ó...porque uma coisa é muito certa, muitas vezes o pessoal que trabalha assim na área, que faz a reintegração, não pensa nisso, que ......... toda pessoa que vive numa situação dessa, por mais que...., tem os contratempos né, mas ela é assim livre, não tem que dar satisfação para ninguém sabe, pode ir e vir à hora que quer, quando quiser sabe, e na casa dela ela já, a liberdade dela é mais limitada, sua mãe não vai deixar você ficar zanzando à noite, então uma pessoa que vive nesta situação nunca mais ela quer.... sabe....

R: Isso é melhor do que viver em casa, com comida com tudo, essa liberdade pra você foi melhor...

Pm: É assim...., num tempo assim, na época, quando você é pequeno e tal não entende bem o sentido da palavra liberdade, sabe..., porque na verdade não é uma liberdade, é uma liberdade ilusória né, mas mesmo assim eu.......

R: Fala mais disso.....

Pm: Bom eu...., eu penso assim que...acaba tendo uma visão distorcida da realidade porque...aquilo ali não ta te ajudando, não ta te fazendo bem, e na verdade você não é livre, ali, você acaba estando preso à situação, não pode ir em certos lugar, sabe, você tipo tem que lutar pela sua subsistência, não é igual em casa, que tipo assim, mesmo se eu não trabalhasse eu teria ali um arroz e feijão, agora se eu to na rua, se eu não ir fazer o corre, não ir procurar, não vem na boca sabe, então você apreende a lutar também.....você apreende a lutar apanhando, você apanha primeiro, apanha, apanha, apanha e aí depois você apreende a lutar e depois que você domina isso, essa arte de você saber conversar com as pessoas, saber que lugar que você vai, onde conseguir dinheiro, sabe, você não quer mais sair disso, quer dizer, enquanto ta, você é pequeno assim e você não quer, por isso que é bem difícil assim a reintegração de uma criança que ta em situação de rua com a família, que ela vai saber que ela ali é limitada, que a liberdade dela ali vai ser limitada, e já aqui fora não é limitada, só que em contrapartida tem mais peso do que lá dentro né, porque na sua casa você ta protegido e aqui não, então você acaba ficando mais forte, você acaba sendo obrigado a amadurecer sabe, exercer uma certa autoridade nas suas palavras, nunca abaixar a cabeça para as pessoas, sabe, é..... é como se fosse uma selva, o animal quando ele nasce assim, quando ele fica um pouquinho grande a mãe já diz assim: ó vai viver a sua vida - e ele apreende com os erros e é igual aqui quando você ta em situação de rua....

$\mathrm{R}$ : E como é isso de nunca ter que abaixar a cabeça, fala um pouco mais disso... 
Pm: Bom é assim....veja bem a......quando você ta em situação de rua aqui num...., sei lá...num existe um melhor que o outro sabe assim....., vou falar assim eu estudei mais que você...., eu vivi isso você não viveu, sabe...., assim você só alcança uma certa autonomia exercendo um medo sobre as pessoas ou batendo de frente com o medo que as pessoas tentam impor, tanto a polícia quanto a sociedade em geral, até no meio das pessoas que vivem na situação, então a questão é a seguinte, sempre...sabe, hoje não, hoje em dia eu não vejo mais isso, mas naquela época era assim, cada turminha assim de rua tem seu território sabe, que nem aqui em Pinheiros era nossa turma aqui de Pinheiros, quando vinha alguém de fora mesmo que a gente não queria brigar a gente tinha que brigar com as pessoas sabe, antigamente era assim, resolvia nisso: -É você ta vindo na minha área, num sei que, vamos resolver isso.... Muitas vezes você não brigava sabe, só que você colocava um amigo seu pra brigar com outro, sabe.....que nem: - É, coloca os dois menor pra brigar.....; sabe sempre era os menorzinhos... (rindo)

R: Sei....

Pm: Cêis dois briga aí, e quem ganhar ganha a razão, sabe, então sempre tinha, tinha muito essa coisa de gangue naquela época, sabe....

\section{R: Defender território.....}

Pm: É..., você tinha que defender porque era desse território que você tirava sua subsistência, então você tinha que lutar por ele, você tinha que defendê-lo, e sempre..., muitas vezes vinha gente assim, até você tinha que bater de frente assim com até..., de certa forma traficante sabe, porque a gente viva assim de uma maneira, aqui em Pinheiros, que nós colocamos assim, que não ia ter essa coisa de você roubar e tal, tanto que naquela época num tinha essa coisa de roubo em farol e essas coisas, só tinha uma regra que tinha que ser seguida...

\section{R: Qual regra..?}

Pm: Era assim você não podia roubar aqui em Pinheiros, você não podia brigar com o pessoal, com os moradores, você tinha que ter uma amizade com os moradores, tanto assim que era comum no Natal os moradores davam uns negócios pra gente sabe .... tinha aquela relação de amizade, o que já não acontece hoje, sei lá, acho que desvirtualizou um pouco, que o pessoal daquela época foi crescendo, foi seguindo sua vida, e os novos que vieram já não cataram esse modo de ...., esse modo de vida, né.....

R: Hoje em dia é....eles não respeitam.....

Pm: É, eles não respeitam.

R: E na sua história na rua, como é que foram assim amigos, inimigos, que você fez que você teve?

Pm: Ó...,inimigos assim eu não tive tantos porque eu sempre fui uma pessoa assim, eu não sei porque..... sempre, desde criança, desde quando eu aprendi a ler, eu gostava muito de ler, então eu....assim, quando você gosta de ler, você gosta de falar também né, então a maioria das briga assim eu era como se fosse um intermediário, eu gostava de resolver no diálogo, meus amigos: - Não vamos chegar lá quebrando tudo; eu falei: -Não, primeiro vamos ver, vamos conversar, se der para resolver na conversa, a gente resolve na conversa, sabe, então até mesmo, muitas vezes alguns amigos se deram mal por isso sabe, de eu chegar e dizer assim: - Não, vamos tentar resolver na conversa, a maioria das vezes dava pra resolver, que era coisa besta, só que era através de coisa besta que muita gente morria na reta e também morre até hoje, mas tinha outras vezes que não dava pra resolver na conversa... 
R: E amigos, você teve algum importante, que você lembra?

Pm: Ah!..., teve assim que nem o...., dois amigos assim o T. m. e o A. m., teve uma importância assim que a gente até hoje sabe, ele, os dois, cada um seguiu o seu caminho, era da hora que a gente era como um trio sabe...., aí era assim, eu tinha estudado um pouco mais que eles, então sempre tentava inserir eles no hábito da leitura e tal, falava: -Vamos na gibiteca, vamos fazer isso, vamos fazer aquilo.

O T. m. se interessava mais, tanto que ele aprendeu a ler assim por esse incentivo: Não vamos ler gibi, vamos lá na gibiteca ler gibi, assistir um desenho, o A. m., ele apanhava muito assim, ele era....

R: Espera só um pouquinho, eu não quero que você interrompa não mas a fita ta acabando e eu vou virar ta.....

R: Agora eu já virei a fita....

Pm: Então..., o Alex ele é uma pessoa assim que desde criança ele teve um contato mais bruto com a criminalidade sabe...., ele apanhava muito do pai dele, padrasto né (o tom torna-se mais sério) do padrasto dele, da mãe dele, até do pessoal que ficava com ele, então ele era uma pessoa assim que ele...., tinha uma tendência a seguir... mais pro lado da marginalidade sabe...., ele já queria: -Não, vamos resolver na briga. Só que era assim, ele era uma pessoa extremamente calma, tanto que eu acho assim, ele tivesse conhecido outras coisas ele estaria numa situação melhor né....., mas foi marcante porque... era como se fosse a minha família essas duas pessoas sabe, a gente andava junto pra qualquer lugar: -Vamos fazer isso, vamos ir junto, que era assim que a gente tinha um lugar lá em Pinheiros, uma casa abandonada, que colava bastante gente, só que era assim, de dia não ficava aquela montueira de gente sabe, cada um ia fazer uma coisa: -Ah eu vou fazer isso; eu vou fazer aquilo; eu vou pra Santana arrumar dinheiro; eu vou pra tal lugar, tal, tal, tal, e nós três sempre fazia as coisas juntos sabe, então era como se fosse a minha família.

R: Os outros que viviam na casa não tinham amizades assim como esse trio que você fala...

Pm: É assim, tinha amizade..., sabe o que é que acontecia...., é que nós três nunca brigamos sabe, nunca chegamos a brigar, as outras pessoas não, vira e mexe tinha uma briga, uma discussão, nós não, nós se entendia assim mais ou menos..... e por isso que a gente seguia assim a caminhada.... mais junto....

R: Sei....., me fala uma coisa, o que você acha que de importante, tanto de bom como ruim, que você aprendeu ou ensinou com seus amigos.....

Pm: Eu acho assim que uma coisa importante que eu passei para eles ....

R: Importante que eu quero dizer é o que ficou marcado...

Pm: Eu acho que foi assim a questão da leitura assim..., que quando eu conheci eles, eles não sabiam ler sabe, eles tinham vontade de aprender a ler, só que tinham vergonha...., então eu catava um caderno...: - Não, o abecedário é assim e tal, eu acho que isso ficou marcado, mas tanto pra mim quanto pra eles sabe....e, deles assim naquela época eu não gostava de música, eu não ouvia muita música, o A. m. já ouvia bastante música, então eu catei este hábito de ouvir música de gostar assim com ele sabe, e com o T. m. eu passei a gostar da capoeira, que ele fazia capoeira, e eu no começa não gostava e depois eu comecei a interar, saber um pouco da cultura brasileira...e, isso eu acho que foi marcante....

R: Fora esses dois teve alguma pessoa, uma pessoa na rua que foi marcante..... 
Pm: Ah! ; eu acho que de primeiro momento assim até o segundo ano que eu tava nessa situação eu acho que todas as pessoas foram importantes, sabe porque, porque eles me ensinaram um pouco, sabe que nem tipo eu conheci, eu conheci um homem, eu nem me lembro o nome dele, ele que dava a letra assim: - Não, vamos arrumar um dinheiro, eu sei um lugar onde a gente pode arrumar um dinheiro, sabe...que ajudou um pouco você a se locomover, foi como eles foram passando tudo aquilo que eles sabiam e eu fui apreendendo né..., eu acho que até o segundo ano assim todas as pessoas que eu tive contato assim foi marcante, antigamente também não tinha esta questão, tinha né, só que era mais isolado, a questão da droga, então você só queria curtir sabe: - Vamos arrumar comida, não vamos jogar Fliperama, sabe. era assim....

R: E hoje o que mudou....

Pm: Ah!; hoje muda tudo, hoje muda tudo, até pela questão do, da, do, da criminalidade... ter acuado um pouco a população, em contrapartida elas....forçam os policiais, cobram ação dos policiais sabe, então hoje em dia eles já exercem um abuso maior de poder que existia na época...

R: A polícia...

Pm: É, tanto que tinha assim alguns fatos isolados que aconteceram sabe que era assim, eles não queriam, até hoje eles não querem, que exista moleque de rua certo e, naquela época era assim, a gente tinha bastante amigo na população, então eles não podia chegar e ir eliminando que nem em alguns lugares eles faziam, no Rio de Janeiro e tal, igual lá na Candelária, sabe... e aqui eles não podiam fazer isso...., então eles tentavam de alguma forma ou colocar a gente na cadeia ou bater, só que não tinha como, tanto que uma vez dois fatos que aconteceu, uma vez nós estava indo numa ruazinha que tem ali embaixo, que a gente chama de rua de ...... Paulo Gontijo de Carvalho que assim é bem escura, fica entre prédios assim sabe, fica bem escura assim, nós estava passando lá, eu e mais dois amigos, a gente encontrou dois policiais assim que era os que mais, sabe, mais detestava a situação das pessoas que mora na rua, então eles cataram um amigo meu que era o maior assim e pisaram na cara dele e tal, bateram nele pra caramba e outra coisa aconteceu, foi até um teste pra mim, que a gente foi enquadrado né, nessa rua mesmo, aí tinha dois policiais, aí um...chegou, tava batendo lá nos meus amigos e aí o outro chegou e falou assim, que lá nessa rua funcionava um local de tráfico e eles queria descobrir quem era...., aí tava batendo lá nos meus amigos e outro me chamou assim e colocou uma arma na minha cabeça e falou: -Vai meu fala aí, o que você sabe do tráfico. Eu falei assim:

- Meu, eu não sei de nada, nem conheço. - Fala, fala, fala.....

R: Você. sabia ou não sabia....

Pm: Sabia né, que você conhece..., você que não pode falar que você sabe né..., aí o outro policial batendo lá ele viu que eu olhando assim, que você fica assim com um pouco de raiva, o moleque não tava fazendo nada e apanhando de graça assim, ele chegou né, abriu o carro, tirou uma arma assim e falou, não primeiro ele falou assim: - Esse policial é folgado pra caramba né, gosta de ficar batendo nos moleque; aí ele abriu o carro pegou uma arma e falou assim : -Tó, dá um tiro nele, aí eu deixo você ir embora. Só que eu sabia que aquilo lá era uma jogada, logicamente que a arma tava descarregada, a partir do momento que eu pegasse eles iam...., iam me matar sei lá....

R: Você percebeu....

Pm: É lógico..., mas direto acontecia isso...... 
R: P. me fala uma coisa, voltando um pouquinho agora.., o que você lembra da sua mãe.

Pm: Da minha mãe eu não lembro nada, eu até às vezes faço uma força assim pra lembrar de alguma coisa, porque eu penso assim, do meu pai assim eu lembro dele, quase nitidamente sabe, não lembro assim do rosto dele, mas eu lembro assim como ele, duas vezes que eu vi ele eu consigo até hoje, todo dia eu lembro da cena assim, de como aconteceu essas duas abordagens, só que da minha mãe eu não, às vezes eu acho até meio estranho né, porque será..., e eu passei mais tempo com ela do que com o meu pai...

R: Mas você lembra como se sentia quando morava com ela, alguma coisa assim...

Pm: Ah não lembro...

R: E você disse que ela foi embora, porque que ela foi?; o q você acha?

Pm: Bom ela não queria mais, sei lá, criar a gente, foi embora viver com um cara e deixou a gente lá na casa (risos).

R: Deixou a casa com vocês.....

Pm: É assim vazia, depois de 3 meses assim aí minha tia ficou sabendo, essa minha tia que faleceu, aí ela foi lá buscou a gente e levou a gente pra morar com ela...

R: E vocês ficaram esse tempo todo só os 3 ?

Pm: É.

R: Dentro da casa..., e o que você lembra....suas irmãs, reclamando, pensando...

Pm: Não eu não lembro, eu só lembro assim de que pareceu assim, que a gente estava trancado sabe, a gente não tava trancado mas a gente se sentia, sabe quando a gente se sente assim sozinho: -Cadê minha mãe e tal?; e eu não conhecia ninguém lá aonde a gente morava...minha irmã conhecia. É eu só lembro assim de eu estar num lugar um pouco escuro assim e tipo sozinho sabe quando você ta sozinho e você procura as pessoas tipo assim não acha, bom acho que de certa forma deve ser isso que deve ter bloqueado assim parte das lembranças que eu tinha da minha mãe..., tanto que eu, tipo, carreguei uma mágoa dela assim, sabe antigamente eu não gostava dela não, aí eu conhecia uma pessoa que ela, sabe, falou assim : - Pô, pensa bem, a tua mãe tinha 24 anos, como será q era pra ela, isso aquilo. Mas mesmo assim até hoje eu queria sim encontrar ela, só pra gente conversar sabe.

R: O que você queria saber dela...., o que você queria falar pra ela...

Pm: Bom eu só queria perguntar pra ela porque ela foi embora, nada mais, não queria nem viver com ela, nem passar a gostar dela (risos) sabe...

R: Queria só uma resposta,,,,

Pm: É só isso....

R: E você tem alguma suspeita assim....

Pm: De onde ela ta...?

R: É..., de onde ela ta, porque que ela fez isso, você no teu pensamento o que você acha? 
Pm: Sim, eu não consigo entender isso sabe, porque ela foi embora, então não tem como eu imaginar, ah ela foi embora por causa disso, eu não sei como é que era a situação dela na época, sabe...

R: E você sabe onde ela está?

Pm: Não sei ...., sei mais ou menos, que nem a minha tia já encontrou ela alguma vez, ela mora lá no Taboão também, bom ela sabia onde a gente morava, êh...êh..., se ela quiser, por isso muita gente fala assim: -Vai procurar sua mãe e tal. Eu falo assim:

- Não num vou porque, minha vida inteira ela sabia onde eu morava, se ela quisesse me ver ela ia lá, né...

R: E como foi assim essa passagem, a tua tia descobriu depois de 3 meses, o que você lembra disso, como foi que aconteceu?

Pm: Bom eu lembro do dia em que ela foi lá buscar, buscar a gente, eu lembro que a gente estava assim em frente de casa, aí ela chegou: -Bom, vocês vão morar lá comigo. Aí eu lembro como é que era, e daí pra cá eu não lembro das coisas..., como que era a vida na casa da minha tia e tal.

R: Como era, você ficou um pouco com ela e depois foi pra sua avó...

Pm: É fiquei alguns meses com ela....

$\mathrm{R}$ : Conta o que você lembra.

Pm: É era assim, a gente, era uma casa assim grande sabe, e morava bastante gente, então era legal, a gente acordava umas 8 horas da manhã e tal sabe, tinha uma vida boa, ficava só brincando o dia inteiro, eu conhecia alguma s pessoa lá de onde eu morava...

R: Era num bairro...

Pm: Era num bairro...

R: Mas P. , essa tia que foi buscar vocês é a mesma com quem você voltou, mais tarde..

Pm: É..

R: Mas então quando você era pequeno era um ambiente legal, e quando você voltou tinha mudado o ambiente, mudou alguma coisa pra isso acontecer...

Pm: Eu acho que a luta do dia a dia, a pessoa acaba ficando rústica de tanto sofrer assim, acaba se fechando né, bom acho que foi isso...

R: Então eu não quero prolongar muito pra não cansar, mas se você aceitar, num outro dia eu volto e a gente fala de outras coisas...

Pm:Ta bom.

R: Mas antes de concluir eu queria que você falasse um pouquinho mais desse período que você viveu com a tua tia e como foi mudar pra casa da tua avó...., como foi na tua avó, aí a gente encerra por hoje.....

Pm: Bom, é..., teve assim um, uma mudança assim bem mesmo, porque lá na casa da minha tia era assim, o ambiente era legal sabe, só que era assim por ter, sei lá, um atrito entre irmãos, num tinha assim essa questão tanto do afeto, tinha assim um carinho com as minhas primas assim, tal com o marido dela, não muito né, mas a gente saia às vezes..

R: Mas as brigas entre irmãos eram que irmãos, você e as suas irmãs ou os seus primos... 


\section{R: Como assim...?}

R: Não, eu entendi você dizer que tinha muita briga entre os irmãos...

Pm: Não assim com os irmãos da minha tia...e, até mesmo com os filhos dela, não tinha aquela união, tinha muita briga assim...

R: Isso te incomodava...

Pm: Ah, no começo assim eu achava diferente, porque na minha casa eu não lembro de ter briga lá, e você depara com briga e você já não entende aquilo: Pô o que está acontecendo., sabe, porque uma pessoa fica sem se falar com a outra, porque minha prima ficou um tempo sem falar com a minha tia sabe.....

R: E aí você ficou uns 3 meses lá....

Pm: É , então aí quando eu fui morar com a minha avó eu....achei diferente porque... lá tinha assim, a família já era mais unida, tinha esse carinho que nem tem um irmão do meu pai que ..., que a gente....era muito amigo assim, que ele era muito amigo do meu pai, começou a morar lá em casa...(risos), tinha aquele carinho assim....

R: Então tua avó era mãe do seu pai...

Pm: É , mãe do meu pai, ...... aí tinha mais união na família, minha avó, putz, ela gostava muito do meu pai e nessa época o meu pai já tinha falecido....

R: Quantos anos você tinha quando ele morreu....

Pm: Ah..., eu tinha uns dois anos, foi nessa época, eu só vi ele duas vezes.....

R: Ah..., era pequenininho ainda, antes dos dois anos, na prisão...., mas e aí, você tava falando do seu tio, da sua avó...

Pm: Bom então, ali já tinha mais um afeto assim, ela sentava e conversava e falava: Não, não é assim e tal. Os meus tios, tinha aquela união de um parente se ver, num tinha assim briga, só tinha uma briga na família, que era assim, a minha prima..., é..... irmã da minha tia, que lá só tinha uma mulher, dos irmãos do meu pai só teve uma mulher, o resto era tudo homem, então a filha mais velha dessa minha tia não gostava muito da minha.., não é que não gostava, por minha tia ta sempre trabalhando ela foi criada com a minha avó sabe, então ela respeitava mais minha avó, ela já tinha 19 anos e ela não tinha assim aquela relação de mãe pra filha, ela tinha essa relação com a minha avó, então sempre tinha um atrito assim entre elas e o meu tio não gostava, aí ficava aquele triângulo sabe, meu tio não gostava do que ela fazia com a minha avó, com a minha avó não, com a minha tia e a minha tia não brigava com ela e aí o meu tio via aquela situação e brigava com ela e falava: - Não meu, não é assim, não sei o que...e tal......

R: Queria mais respeito com a mãe dela, né....

Pm: É.....

R: E daí como é que era mais lá, era no interior né....

Pm: Não, era aqui em SP, no começo nós mudamos aqui pra Osasco, ficamos uns meses aqui e depois nós fomos para o interior, aí fui morar eu e minha avó...

R: Aí mudou assim, foi pouca gente.....

Pm: Foi só, assim, foi um pouco de gente, só que aos poucos o pessoal ia voltando pra SP, porque viver no interior é cruel né, a questão do emprego e tal, aí no final só ficou eu e a minha avó lá e, eu não gostava de lá, não gostava.... 


\section{R: Porque?}

Pm: Por que era um lugar muito parado...(risos), não tinha nada pra você fazer sabe. (toca o telefone e o P. atende, pausa)...

R: Então você tava falando que o lugar era muito parado....

Pm: É então não tinha ..., um sítio assim sabe....

R: Vocês moravam num sítio...

Pm: É...

R: E você não tinha amigos?

Pm: Tinha amigos assim, só que (o telefone toca novamente, pausa).

R: Então vai, retomando..

Pm: Então lá....., nessa época eu tava fazendo 7 anos sabe, então é época que você começa a ir pra escola, aí você começa a ter outra visão de mundo né e, eu já tava acostumado com SP, por mais que eu era pequeno assim e...e....e outra coisa que era legal lá com a família por parte de pai, que eu tinha uma liberdade assim, meu tio falava assim, quando eu morava com meu tio: -Ó..., você pode sair pra onde você quiser, só que você tem que estar aqui na hora do almoço e 6 horas, pra entrar, tomar banho, jantar e tal. Essa era as duas coisas que ele cobrava, esses horários assim, então eu pegava um ônibus assim, ia conhecer Osasco, que eu não conhecia a cidade....

R: Mas Osasco?

Pm: É

R: Mas você não disse que você saiu com dois anos, que a sua mãe foi embora e aí você foi pra sua tia..

Pm: Mas só que era assim, a minha avó, ela tinha um problema no coração, ela usava marca-passo, então de 3 em 3 meses a gente tinha que vir em SP.

R: Ah..., entendi

Pm: Entendeu, então a gente ficava alternando assim entre interior e SP, interior e SP, que ela vinha se tratar aqui no Hospital São Paulo, que tinha um acompanhamento...

R: E quem é que morava com vocês lá junto com a sua avó...

Pm: Aqui em SP?

R: Não..., é..., aqui em SP e depois mudou né?...e como é que foi, a família assim...

Pm: Não, quando a gente foi pro interior fui eu e todo mundo que morava na casa, eu, a minha tia , minha primas, o marido da minha tia, só que aos poucos a minha tia voltou pra SP, ela o marido dela e as filhas e ficou uma filha só lá..., depois voltou também por que lá era complicado assim...

R: Agora essa tia que foi com vocês pro interior é a mesma que você foi lá pra casa dela e depois você voltou ou é outra?

Pm: Não..., é aquela que quando eu saí da casa da minha tia por parte de mãe, é minha tia por parte de pai..., e quando eu saí lá, que eu fui separado das minhas irmãs literalmente eu fui morar com eles, morava eu a minha avó e a minha tia... 
R: Ah..., ta, essa tia que você, então tem a tia por parte de mãe que tirou vocês da casa, você ficou com suas irmãs por um tempo, aí você foi morar com a sua avó e sua tia por parte de pai e ficou em Osasco um tempo e depois foi pra o interior, é J aboticabal?

Pm: Não, é Catanduva..

R: Ta e, aí quando vocês foram pra Catanduva foi todo mundo e aos poucos as pessoas foram voltando...

Pm: E aí no fim só ficou eu e a minha avó lá, é assim e, eu ficava muito, com muita ansiedade assim por que lá não tinha o que você fazer sabe, lá na cidade ou você vai nadar no rio..., ou você vai andar lá no canavial, comer umas frutas, ficava andando assim né...

R: Você tinha amigos?

Pm: Tinha bastante amigos assim...

R: Morava aonde, era casa, era sítio....

Pm: Era uma casa assim num sítio, era assim um pouco isolada, ficava perto de um canavial, perto de um rio, o rio passava assim bem no quintal de casa, era legal, hoje em dia eu..., sei lá, eu preservo isso, eu acho legal isso, eu gosto do interior, mas naquela época eu só queria vir pra SP., por que aqui eu tinha muito mais amigos, conhecia muito mais lugares, tinha muito mais coisas pra fazer, não era igual lá...e, outra coisa, lá a escola era muito longe, tinha que andar pra caramba, a escola era lá no centro da cidade, eu morava bem isolado, eu andava bastante dava uma coisa assim de uns 2 quilômetros...

R: E me fala da tua avó um pouco, como é que era, o que você lembra dela?

Pm: Ah..., a minha avó era uma pessoa super-legal sabe, ela me protegia, quando eu fazia alguma arte, ela não é legal por isso, só por isso né, mas ela era legal, quando eu fazia alguma arte ela tava do meu lado, ela sempre tava do meu lado sabe, então era uma pessoa que eu contava com ela, sabe, acho que foi a única pessoa do mundo que eu pude contar com ela, sabe, por mais que tenha sido por um curto período né, mas ela sempre tava ali....

R: E porque que você deixou de morar com ela...

Pm: Porque ela faleceu..., quando eu tinha 9 anos....

R: E da tua avó que mais assim que marcou em você, além dela estar do seu lado...

Pm: Ah!; por que, por que, foi legal por que ela ajudou, assim construiu um pouco a visão que eu tinha do meu pai, tipo ela me mostrou algumas fotos, falava assim como o meu pai era, e, eu achava legal, por que eu, eu tinha sim saudade dele, sabe até hoje assim, que ele era uma pessoa legal...

R: Sei e, quando a sua avó morreu estava só você com ela?

Pm: É

R: Você que encontrou ela morta?

Pm: Não, assim a gente dormia no mesmo quarto, ela dormia numa cama perto da porta e eu dormia assim na parede, só que ela sempre acordava cedo né, aí teve um dia que eu acordei primeiro que ela, só que eu nem, eu era criança, tinha 9 anos, eu nem..., levantei coloquei água pra fazer café, saí e ela tava deitada lá, aí tinha um moço que morava lá nesse sítio também, que ele era tipo agregado assim sabe, uma hora morava lá, dava uma força né, aí ele chegou e 
falou assim: -Ué a dona E. não acordou ainda?. Aí eu falei: - Não ela ta lá dormindo. Aí ele: -Ela acorda cedo pra caramba (risos)....

R: Estranhou..

Pm: É estranhou, aí ele foi lá : -Dona Elisa a senhora não vai levantar não? Aí ele viu o pulso dela assim, e falou : -Aí meu Deus, não sei o que. Aí ligou, eu lembro que foi maior, assim eu não entendi o que foi sabe, assim eu não entendia o que era a morte e, tanto que foi o único enterro que eu fui na minha vida, que eu não vou em enterro, não por não gostar, por que eu acho assim que a pessoa quando morre ela ta indo pra um lugar melhor, então não tem que você ir no túmulo ficar chorando lá, eu acho que o você tem de passar pra pessoa você passa em vida, depois de morta não tem como você passar mais nada né, então só que vê, foi assim, foi diferente, gente que a gente nem conhecia foi em casa, ver ela e tal, interior quando morre alguém é: -Vamos lá, vamos lá.... fica prestando homenagem e tal e ela foi enterrada e aí eu conheci parente que morava lá que eu nem conhecia.(risos).

R: E você falou da imagem do teu pai né, que ela ajudou a construir, o que é que você tem de imagem dele...

Pm: Ah!; eu tenho assim como uma pessoa assim boa sabe, tipo por mais que ele fosse errado, ele era uma pessoa que se importava com a família, já não era o caso da minha mãe, ele se importava mais....

R: Como é que você, o que ele fazia que você achava. isso...

Pm: Eu lembro que a gente não passava necessidade em casa sabe, morava bem e outra eu....

R: Mas ele estava preso...

Pm: Não, então, ele estava preso só que mesmo assim sabe como é que é né., quem ta preso tem como, sei lá, tem como mandar dinheiro pra quem ta fora, tem como ajudar...

R: Mas como, eu não sei, de fato eu não sei...

Pm: É assim ó, dependendo do que você é, assim quando você ta envolvido com a hierarquia da criminalidade, dependendo do grau, do seu grau na hierarquia você tem amigos assim e também tem influências, entendeu, então é assim, se eu sou um cara que eu sou considerado se eu for preso eu teria amigos aqui que vai ajudar minha família sabe....

R: E se você se importar não precisa falar mas, qual era o crime do seu pai, o que ele era assim de importante...

Pm: É que meu pai ele era assim, ele, isso eu descobri depois (risos), que ele roubava banco né, essas coisas..., a família do meu pai inteira assim já teve um contato com a criminalidade só que alguns saíram e outros foram presos, outros morreram...

R: E o seu pai morreu por que?

Pm: Ele morreu de ataque cardíaco, ele tinha um problema do coração, tanto que quando eu era pequeno eu também tinha esse problema, é se eu ficasse nervoso assim eu...., até hoje assim eu sou uma pessoa assim muito ansiosa sabe, por isso eu fui fazendo tratamento quando eu era pequeno, por que você tem de fazer o tratamento quando você é pequeno, aparecia umas manchas assim no corpo, sabe quando você fica muito nervoso começa aparecer umas manchas... 
R: Ta bom, mas e aí você tava falando da imagem do teu pai, que ele era um cara legal, que se importava, que mais você...

Pm: É também por que eu era o único filho homem, então ele tinha um carinho assim sabe, por mais que você tenha assim filhas mulheres você sempre vai querer um herdeiro assim alguém pra você jogar bola e tal, conversar e, era legal por que quando eu ia visitar ele assim ele pegava eu no colo e chegava nos amigos dele:

-Esse aqui é meu filho! né.

R: Você lembra?

Pm: Lembro, lembro que uma vez assim nós fomos lá no dia das crianças, os presos mesmo fizeram um bolão assim, você ia lá comia (risos) eu falei ah!!!

R: Legal e você lembra mais alguma coisa?

Pm: Dele não.

R: Fotos...

Pm: A minha tia tinha uma foto dele, eu sei mais ou menos como que ele era por essa foto (toca o telefone, pausa).

R: Bom P. então assim, adorei a conversa.

Pm: É, eu também gostei..

R: Gostou?

Pm: É porque tipo sobre este aspecto eu nunca tinha conversado com ninguém...

R: É, você gostou de ter falado?

Pm: É bom né, você compartilhar um pouco essa carga com alguém que (risos), ...é melhor né.,

R: Claro.

Pm: Porque eu nunca tinha tido esse tipo de conversa.

R: Você se sentiu à vontade!?

Pm: É.

R: Então P eu vou fazer assim, eu vou transcrever tudo isso e aí eu queria saber se você topa eu voltar um outro dia, porque tem algumas coisas que eu gostaria que você falasse mais e tal, pode ser?

Pm: Pode.

R: Então valeu.

\section{Segunda entrevista:}

R: Então P., hoje é sábado..., que dia é mesmo?

Pm: 27

R: 27 de setembro..... O que você está fazendo na escola é...?

Pm: Terceiro colegial. 
R: Terceiro colegial, opa parabéns..., agora encerra um ciclo importante né, e você tem intenção em dar continuidade, o que você está pensando?

Pm: Claro, estou pensando em continuar né ..., uma faculdade, to vendo umas bolsas aí.

R: É em que área?

Pm: Eu to vendo uma na Santa Marcelina pra fazer Relações Internacionais..., mas o que eu queria fazer mesmo é Ciências Sociais....., mas não foge muito da área né, Relações Internacionais, eu tava vendo lá o prospecto do curso dentro das Relações Internacionais você estuda um pouco de Direito, Ciências Sociais...

R: Sei...., onde é esta Faculdade?

Pm: Na...., a Santa Marcelina?; Ali na Cardoso de Almeida, perto da PUC, uma que tem do lado direito, parece uma Igreja assim.

R: Mas lá é pago?

Pm: É lá é pago mas só que eu to vendo se eu consigo uma bolsa, porque a M. (pessoa da diretoria da AMC) dá aula lá.

R: Ela trabalha aqui, ela é da diretoria.

Pm: Sim.

R: Ah!; certo ela dá aula do que?

Pm: Acho que é de música.

R: Que bacana, aí você tem de se preparar pra fazer um vestibular....ta certo..., então Paulo, dando continuidade no meu trabalho eu to fazendo assim, eu entrevistei você, entrevistei algumas outras pessoas, aí eu releio tudo, vejo algumas coisas que faltam, que são importantes, que eu gostaria de investigar melhor, vão surgindo novas idéias e aí eu vou perguntando para as pessoas se elas estão dispostas a continuar a conversar para esclarecer outros pontos, então esta aqui é uma pasta sua que eu estou começando a guardar, com aquela entrevista que a gente teve, com algumas análises e, eu queria inicialmente pegar algumas informações que são assim pra eu me organizar melhor. A gente vai fazer uma coisa que se chama heredograma, é como se fosse uma árvore genealógica, então o nome da sua mãe qual era?

Pm: C.2, ehhhh..., C. 1, que C.2 foi a que me criou.

R: C.1, essa é sua mãe verdadeira e o seu pai chamava-se como?

Pm: V.

R: O seu pai é morto não é?

Pm: É, falecido..

R: Você sabe quantos anos ele tinha quando ele morreu? Ele morreu quando você tinha dois anos ou três?

Pm: É.

R: Você está com 18, 19.

Pm: Ele devia ter uns 30 anos.

$\mathrm{R}$ : Aproximadamente 30 anos.

Pm: Aproximadamente.

R: E ele morreu em que ano, em 86 por aí, foi mais ou menos por aí. 
Pm: É $86,87$.

R: Você nasceu em que ano?

Pm: 84

R: Então 86, 87,ta certo; da sua mãe você...... tem notícia que ela está em algum lugar mas..

Pm: Não conheço.

R: Você nunca mais encontrou né... e, aí você tem os seus irmãos, a mais velha é uma moça e qual é o nome dela?

Pm: C.f.

R: C., ela está com quantos anos hoje?

Pm: Ela , 27, que ela é oito anos mais velha.

R: Oito anos mais velha, ela ta casada né, em seguida vem você?

Pm: Não vem a minha outra irmã.

R: A sua outra irmã..., com quantos anos?

Pm: Com........23.

R: E aí você, era só vocês três não é? Isso aqui chama-se heredograma (mostrando o desenho), quadrado é o homem e os círculos as mulheres, aqui são os pais, aí vem os filhos, quando tem um corte assim quer dizer que a pessoa faleceu, entendeu.

Pm: Não vai colocar a idade dela? (referindo-se a mãe).

R: Fala, você sabe?

Pm: É............., bom eu nasci..., 41 anos né, quando eu nasci ela tinha 22 anos.

R: Então hoje ela tem 41 anos, você nasceu ela tinha 22, mas então ela deu a luz a sua irmã muito cedo...

Pm: Ela tinha 14 anos..

R: Tinha 14 anos, todos são do mesmo pai? Você nasceu..., seu pai..., ele tava solto quando você nasceu?

Pm: Quando eu nasci ele já estava preso..

R: Então enquanto você estava sendo gerado, quando sua mãe estava grávida...

Pm: Aí ele tava solto.

R: Ele tava solto mas foi preso..

Pm: É ele foi preso faltava uns meses assim...

R: Pra você nascer...., isto tudo deve ter deixado sua mãe nervosa....Bom então

P. você nasceu em mil novecentos e....

Pm: 84.

R: 1984, aí a sua mãe abandonou a casa com vocês, você tinha uns dois anos ou três anos...

Pm: É uns 3 anos, foi em 87 mais ou menos..

R: 87. 
Pm: Não, menos, porque quando meu pai faleceu, ela já tinha....

R: Ela já tinha ido...

Pm: É eu tinha um ano e pouco, dois anos de idade.

R: Ah é, então foi lá por 85,86 , sua mãe sai de casa. E o seu pai vem falecer em $86 ?$

Pm: Não, em 87.

R: 87, pai falece, você se lembra de alguma coisa em relação ao seu pai ter falecido? O seu pessoal ficar triste?

Pm: Não isso eu não lembro, eu lembro assim como é que ele era, que eu fui visitar ele duas vezes...

Pm: . Ele morreu no final de 87.

R: Ele morreu foi dentro da cadeia né,, foi de doença ou...,?

Pm: Foi de parada cardíaca.

R: Parada cardíaca.

Pm: Ele tinha um problema no coração

R: Ele tinha um problema..., você contou que foi fazer, que você lembra dele, que foi fazer umas visitas, que teve uma impressão boa, não é isso? Agora quando ele faleceu, a família assim, você lembra da ocasião?; se a família ficou muito transtornada, ou já estavam esperando? Como foi o enterro..., essas coisas assim...

Pm: Ficou assim a minha avó, que na época em que ele faleceu eu tava morando com minha avó que foi quando eu sai da casa da minha tia né e fui morar com ela, ela ficou triste.

R: Você lembra disso..

Pm: Lembro, bom bastante triste né e, o meu tio também, que eu tenho um tio que ele gostava do meu pai pra caramba, e de resto assim eu não lembro..

R: Tuas irmãs?

Pm: Eu não morava com elas nessa época.

R: Então quando sua mãe saiu de casa vocês ficaram acho que dois meses ou três, foi isso que você contou, dentro de casa, tua irmã dando um jeito, não é isso, e até que a sua tia que é a C.2 foi buscar né.., então ela foi buscar em 1986 ainda. Tia C.2. leva todos pra morar com ela, quanto tempo você fica com sua tia C.2.?

Pm: Eu fiquei até outubro de 87, foi no dia das crianças assim que eu fui passear com a minha avó e fiquei morando lá.

R: Mas você sabe se foi um ano ou menos....

Pm: Que eu fiquei com a minha tia?

R: É...

Pm: Acho que foi uns 8 meses, não foi muito tempo não.

R: Aí você vai morar com a avó que chamava?

Pm: A. 
R: A., bom então você vai e suas irmãs ficam morando com a C.2. e você vai morar com sua avó e vocês vão morar no interior.

Pm: É.

R: Já direto.

Pm: Não, a gente vai pra Osasco, fica lá um ano mais ou menos morando lá, um ano não uns dois anos que a gente foi pro interior em 89.

R: Dois anos, e em 89 vai para?

Pm: Catanduva

R: Catanduva.

R: Nisso você tinha 5 anos então...

Pm: É.

R: Quando você vai pra Catanduva quem te acompanha alem da tua avó?

Pm: Vai eu, minha avó, uma tia o marido e os filhos dela.

R: Qual é a tia?

Pm: S.

R: Tia S..., a C.2. é irmã da sua mãe e a S. é irmã do seu pai e o tio, marido dela?

Pm: A.

R: A., vão todos pra lá e ...., primos?

Pm: Três primas.

R: Era bom? Era divertido ficar com as primas?

Pm: Ah!; não era muito bom porque eu acho que quando você é moleque assim você necessita mais de um outro moleque, que às vezes nem tudo o que você gosta de brincar a suas primas gostam.

$\mathrm{R}$ : Certo, e as primas eram mais velhas, mais novas, como era?

Pm: Tinha uma que tinha a mesma idade que eu, que nasceu no mesmo mês, a A.f..

R: A.f., então ela também tinha...

Pm: A mesma idade, ela nasceu na mesma época..

R: Cinco anos.

Pm: É

R: E as outras?

Pm: Tinha uma mais velha, M. f.

$\mathrm{R}$ : Lembra que idade?

Pm: Ela tinha uns .., era uns 5 ou 6 anos mais velha.

R: Mais ou menos 10 anos de idade, e a ultima?

Pm: A outra era pequena tinha uns 2 anos de idade.

R: O nome dela?

Pm: D. f.. 
R: D.f., tinha uns 2 anos, então esse pessoal todo, sua tia S., o seu tio, as suas primas, a sua avó e você foram todos pra Catanduva em 89, e aí a sua tia S. e o seu tio em algum momento parece que voltam pra São Paulo.

Pm: É.

R: Lembra em que ano mais ou menos, quanto tempo foi?

Pm: Foi logo em 90, eles não ficaram muito tempo lá.

R: Então um ano

Pm: É um ano

R: Os tios voltam....

Pm: E duas primas voltam.

R: Ah!; fica uma prima, os tios voltam pra SP com duas filhas, aí ficam a sua avó, você e qual prima?

Pm: A M.f.

R: A mais velha.

Pm: É

R: Ficam vocês dois morando com sua avó e a M.f. ficou lá até a morte da sua avó?

Pm: Não, ela veio embora também ela ficou lá uns....., depois que eles vieram embora ela ficou lá mais um ano e meio, dois anos.

R: Em 92 M.f. volta pra SP., e você sentiu a vinda da sua prima, de seus tios?

Pm: Ah!; você sente assim que a casa fica mais vazia, mas não muito com essa minha tia..., das minhas primas senti falta que você conversa, mas com minha tia assim a gente não conversava muito e eu quase não via ela, que ela saía pra arrumar emprego e tal..., mas fica um pouco ruim porque não tinha muita gente pra conversar né, da família.

R: Então do que eu me lembro do que você me contou...., dos adultos que pertencem à sua família você não teve alguém que fosse muito próximo, exceto sua avó, é isso mesmo? Me corrija se eu estiver errado, que eu me lembro de você falar: - Olha, a casa ..., assim meio distantes, as pessoas meio frias, ninguém conversava muito.., é isso?

Pm: Eu acho que eu tive um pouco mais de proximidade foi com a minha avó e o meu tio.

R: Qual tio?

Pm: J., irmão do meu pai, que foi me buscar quando minha avó faleceu, eu fiquei uns três meses morando com ele.

R: Mas essa proximidade aconteceu só depois que sua avó faleceu?

Pm: Não, antes, bem antes.....

R: Em que época?

Pm: Desde que eu era pequeno, eu saía com ele , passeava...

R: Então tio J., irmão do seu pai, desde pequeno mesmo antes de sua mãe ir embora ele já....

Pm: Não, depois, desde a época em que eu fui morar com minha avó. 
R: Ah!;ta, em Osasco e ele foi pra Catanduva também?

Pm: Não...

R: Não, porque quando você foi pra Osasco você tinha 3 anos, então ele freqüentava lá e o que fazia o seu tio J.? Ele tinha profissão?

Pm: É ele era pintor, ele trabalhava na Encol.

R: Era pintor e trabalhava na Encol. Essa era uma firma importante!!!!?

Pm: Era uma construtora, hoje em dia acho que ela nem existe mais, até uma época que faliu..

R: Ah!; aquela que faliu, que fez um monte de prédios e acabou não entregando, teve problemas.... e o que você lembra desse seu tio J., ele ia até lá, visitar...

Pm: Eu lembro assim que era legal, que tudo o que eu pedia assim ele me dava, ou conversava assim como se fosse uma figura paterna sabe, tipo dava aquele auxílio que meu pai no momento não podia me dar, assim de conversar e tal...

R: E ele ia com muita freqüência lá?

Pm: Ia todo fim de semana, porque era assim, quando a gente morava em Osasco morava assim bem próximo..., era num bairro vizinho assim e ele ia lá direto porque minha avó já era de idade e outra, essa minha tia S., ela tinha outra filha, adulta já e como ela não gostava muito da mãe dela, elas brigavam muito e aí meu tio ia direto lá pra conversar com elas sabe, porque ela não era filha desse marido dela, então não respeitava muito ele.

R: Espere, quem que não era filha?

Pm: A I.f., a filha mais velha dela.

R: Da S.?

Pm: É que ela não veio pra Catanduva.

R: E ela brigava muito com a S. e com a avó também..

Pm: Não, com a avó não.

R: Não... e o seu tio J. ia lá pra apaziguar as brigas..

Pm: Ia bastante, bom porque ela já era adolescente, já tinha 19 anos...

R: E o que você acha da adolescência?

Pm: Bom é um período difícil da vida, muito inconstante.

R: Muito o que?

Pm: Inconstante assim, você não tem um passo firme sabe, você não consegue pisar no chão com firmeza ainda, mas acho que faz parte do processo da vida....., essa minha prima ela era muito legal sabe.

R: Essa adolescente e o que seria pisar com firmeza pra você?

Pm: Eu acho que é você ter certeza do que você quer, o que você vai fazer, você ter uma visão de futuro concreta sabe, não tem aquela coisa de você ter várias possibilidades de futuro, você tem de escolher uma, sabe então você não sabe muito onde ir, como ir...

R: Quais são as possibilidades que você imagina?

Pm: Ou você ir pro lado errado da vida, ou se internar em drogas, ou você seguir trabalhando a, para de estudar, ou você só estudar sabe, é até uma 
questão de quando você está terminando o colegial, 'o que fazer?', sendo que aquela profissão que você escolheu vai te acompanhar pelo resto da vida sabe, são escolhas difíceis.

R: Mas você não está achando muito definitivo não? Porque veja, você escolher uma profissão,ta é um passo importante mas você pode mudar, as pessoas mudam, escolher caminhos certos é muito difícil, ninguém compra bilhete premiado, ninguém compra um negócio que vai dar certo com certeza.

Pm: E é por isso que eu digo que você não tem um passo firme, porque você fica naquela; - Não, ninguém consegue fazer isso, mas eu quero fazer isso. Eu não quero ter de dar várias voltas para chegar em um lugar, quero ir direto naquele lugar, eu acho que é até um pouco de ansiedade assim em acertar, em não errar.

R: Voltando aqui pro seu tio J., ele tinha filhos?

Pm: Tinha.

R: E mulher também?; e todo mundo ia lá na casa da sua avó?

Pm: A mulher dele não, a mulher dele era ruim pra caramba, ela não gostava muito de mim...

R: E por que, você tem idéia?

Pm: É porque era assim, eu sei lá, porque o mesmo tratamento que meu tio tinha comigo ele tinha com o filho dele sabe, tanto que eu e o filho dele era igual, irmão assim, sabe isso deveria afetar um pouco porque ela não gostava muito do meu pai, eu acho que eles já tiveram desavenças assim no passado.

R: Bom então seu tio conversava, te dava as coisas, você era muito amigo do filho dele, aí quando vocês vão pra Catanduva houve um afastamento...

Pm: Não até que ele não se afastou tanto assim, porque de dois em dois meses a gente tinha de vir pra SP porque minha avó fazia um tratamento...

R: É verdade, o marca-passo....

Pm: É , aí quando a gente vinha a gente ficava na casa dele.

R: E como era voltar pra SP pra você, era agradável, era....

Pm: Era muito bom (rindo), eu não gostava de Catanduva. Hoje em dia eu tenho saudades de lá, mas naquela época quando eu tinha de voltar pra Catanduva nossa era muito ruim, porque lá a gente não tinha assim tanta..., tinha assim bastante parentes, por parte de avô assim sabe, primos de segundo grau, isso tinha bastante, mas eu não conhecia eles, sabe acabei conhecendo assim alguns, mas é diferente..

R: Você não convivia muito. Bom aí...., você em Catanduva começou a estudar né, e passou a morar com sua avó e depois a M.f. veio pra SP e você continuou morando com sua avó e mais lá o rapaz, o cara que morava no terreno.....

Pm: É o caseiro, eu esqueci o nome dele, que ele morava na casa que era da minha tia sabe, ficava tomando conta, cuidava um pouco assim.

R: Você tinha proximidade com ele?

Pm: Mais com a filha dele, que a gente estudava junto...., na mesma sala.

R: E quando sua avó faleceu?

Pm: Foi em 93. 
R: Em 93. Sua avó falece e você volta pra SP. Você veio morar onde?

Pm: Eu fiquei um tempo morando com esse meu tio...

R: Com o J.

Pm: É uns 4 ou 5 meses. Até janeiro de 94 aí eu fui morar com minha tia C.2.. Foi aí que eu reencontrei minhas irmãs.

R: Então você voltou a morar com sua tia C.2., em 94 e reencontra as irmãs. Como foi essa volta? Rever suas irmãs como foi?

Pm: Eu achava tudo estranho porque um monte de gente me conhecia e eu não conhecia eles, eu não lembrava assim um pouco deles, como eles eram, aí tipo assim: a minha prima: - Oi e tal. E eu : -Quem é essa pessoa? E era assim, tinha uma coisa que eu não gostava muito, quer dizer, não é que eu não gostava, é que surgiu assim uma certa diferença porque eu gostava muito do meu pai assim sabe, da figura dele, porque eu não fui criado com ele e, a parte da minha mãe assim, todo mundo falava bem do meu pai a parte do meu pai, e a parte da minha mãe não, só falava mal do meu pai e aí você ficava sem acreditar em quem ele foi, o que ele fez, sabe.

R: E como é a imagem que você tem do seu pai?

Pm: Ah!; eu.... penso assim, normal, que ele se preocupava com a família, que ele se preocupava bastante, e eu acho que se ele não tivesse morrido a nossa vida teria sido diferente assim, a unidade familiar, se ele não tivesse ido preso.

R: Por que você acha isso?

Pm: Ah!; porque ele gostava muito da gente assim.

R: Mas o que te faz pensar isso?

Pm: Até o fato assim das pessoas que conviveram com ele fora da família sabe, e tem toda a família também, alguns amigos dele assim, alguns parentes, falavam que ele era ruim pra caramba, mas que ele se importava.

R: É e ele era ruim de que jeito?

Pm: (risos) Muito sanguinário.

R: Era. E a família o que diziam mais, você lembra?

Pm: Diziam assim que ele se importava em nunca faltar nada pra família, sempre manter aquela unidade, brincar com os filhos assim, bom, nessa época, eu ainda não tinha nascido mas....

R: Você só pode ver seu pai duas vezes né....

Pm: É

$\mathrm{R}$ : E como foram os encontros com o seu pai?

Pm: Ah!; foi legal assim a primeira vez que...

R: Quem foi que te levou?

Pm: Uma vez foi minha tia, outra vez foi minha avó, primeira vez foi minha avó, segunda vez foi minha tia.

R: Qual tia?

Pm: Essa C.2..

R: A C.2.. 
Pm: Não foi diferente, a primeira vez foi a C.2., a segunda vez foi minha avó.......ela até que gostava assim dele sabe, que ele era um cara legal, eu digo assim que mais que não gostava era os primos mais velhos sabe, as minhas outras primas por parte de mãe, a minha tia falava que ele era ruim mas gostava dele, porque ele se preocupava bastante com a gente e eles eram amigos desde....

R: E como foi essa visita, você foi a primeira vez, a C.2. te levou, o que você lembra?

Pm: Bom, eu lembro do que ele falou (rindo satisfeito), tipo assim, quando eu cheguei ele tava no pátio, aí era até acho que dia dos pais, dia dos pais, os presos mesmo fizeram uns bolos pra vender para as visitas e eu lembro que quando eu cheguei assim eu fui, ele me pegou no colo, e disse: - Esse daqui é meu filho. Falando pra todo mundo sabe.

R: Com orgulho.

Pm: É, as palavras assim que eu lembro dele.

R: Dessa vez você não se lembra de mais nada..

Pm: É isso aí e da gente ter ficado lá conversando um pouco, aí eu fui lá comer um pedaço de bolo, aí tinha outras crianças também, aí minha tia ficou conversando com ele lá no pátio, e da segunda vez ele tava numa cela individual, aí eu fui com a minha avó. A gente chegou e ficou o dia inteiro com ele.

R: E o que você lembra?

Pm: Ah!; eu não lembro muito assim das palavras, lembro mais assim da gente sentado na cama, conversando..

R: Foi agradável, desagradável..?

Pm: Foi (rindo), sempre era né...

$\mathrm{R}$ : E o temperamento dele você lembra?

Pm: Eu achava que ele era uma pessoa calma assim, poderia ser nervoso assim se ele perdesse a cabeça, mas...

R: Você nunca presenciou...

Pm: Eu nunca presenciei...

R: E o temperamento da sua mãe, você lembra?

Pm: (longa pausa) não lembro....

R: Como você descreveria a imagem que você tem da sua mãe.

Pm: Bom ela....., não tenho assim muito uma imagem, ela era uma pessoa assim temperamental..., meio nervosa assim mas....., eu não consigo lembrar muito dela..

R: Quando você pensa nela o que vem na cabeça?

Pm: Ah eu não......, eu sei da imagem dela, como que ela era né, que depois eu vi por fotos e tal, mas....

R: Só isso...

Pm: É

R: E das tuas irmãs, como era o temperamento delas? Você lembra? 
Pm: A minha irmã mais velha ela era muito sentimental, muito, tanto que uma vez, eu brincando assim, ela tinha brigado comigo, eu falei assim: - É eu vou te matar. Ela ficou doente (rindo). Tinha uns 5 anos de idade, 4 anos de idade, não uns 3. Ela morava num prédio, eu falei assim: - Ó eu vou te jogar daqui de cima, agora a minha outra irmã não, ela era ruim pra caramba, deve ser né que faz 10 anos que eu não vejo ela, vai fazer dez anos, mas.... tipo assim ela não me respeitava não, minha outra irmã e minhas primas me respeitava porque eu era o único homem da casa, ela não, se eu falasse alto com ela, ela queria vir brigar, ela puxou mais minha mãe.

R: E ela, essa sua irmã , a P.f. né? O que foi dela, ela saiu de casa?

Pm: É ela saiu de casa..

R: Se envolveu com droga?

Pm: Não sei...

R: Você não sabe.

Pm: Ela saiu porque, tipo assim, mais ou menos pelos mesmos motivos que eu saí. Porque lá em casa era...., eu não sei o que acontecia, não tinha assim uma comunicação, era só cobrança isso aquilo, minha tia bebia assim, ficava nervosa.

R: A sua tia C.2. bebia?

Pm: É..., aí não sei o que aconteceu e minha irmã foi embora.

R: Ela foi antes de você?

Pm: Foi, ela foi em 94.

R: Ah!; então logo que você voltou ela foi....

Pm: É eu voltei em janeiro ela foi em abril, maio mais ou menos...

$\mathrm{R}$ : $\mathrm{E}$ você saiu em que ano?

Pm: Em 95...

R: Você ficou um ano praticamente.

Pm: É quase dois anos, que eu sai o final de 95, em novembro.

R: Sei, me descreve um pouco mais do clima que você sentia na casa da sua tia, as pessoas não conversavam, a sua tia bebia.

Pm: Não, lá tinha muita briga.

R: Quem brigava?

Pm: Todo mundo, as minhas primas brigavam com a minha tia, ficavam sem se falar, minha tia brigava..

R: E você nessa época tinha 10 anos por aí...

Pm: É..., é...

R: E o seu tio, como era o nome do...

Pm: J.?

R: Não o marido da C.2..

Pm: Ah o.., o marido da C.2. era C., só que ele era uma pessoa assim...., calminha assim sabe (irônico), ela até batia nele (risos), ele era sossegado. 
R: Não interferia nas brigas, não reagia....E como foi a reação da família quando a P.f. saiu de casa?

Pm: A minha tia ficou preocupada lógico, foi na delegacia, um monte de coisa, só que aí, nesse momento que ela saiu ela foi morar um tempo com a minha outra família sabe, por parte de pai, que aí a gente já tinha estabelecido um contato, depois que eu voltei para a casa da minha tia de vez em quando a gente ia passar o final de semana lá sabe, aí ela ficou uns tempos, não sei quanto tempo...

R: E depois?

Pm: Eu vi ela uma vez depois que ela saiu de casa, só que eu não falei com ela.

R: E sua tia disse o que? Ela ficou nervosa, a C.2., mas o que ela...

Pm: Ela ficou preocupada..

R: Mas ela sabia que ela tava morando lá...

Pm: Não, antes dela saber poderia ter acontecido qualquer coisa....

$\mathrm{R}$ : Mas depois que ela soube, o que ela disse?

Pm: Sossegada.

R: O clima melhorou depois que sua irmã saiu?

Pm: Não mudou muita coisa não, foi mudando assim com o tempo que um primo ia saindo, ia crescendo, ia casando, aí no final só ficou eu, minha tia, e minha outra prima.

R: E como ela tratava você? Como você acha...

Pm: Ela tratava bem porque tipo assim ela conversava assim, ela ensinava assim as coisas, ela queria que aprendesse as coisas, não gostava que eu andava com ninguém dali sabe, ela zelava um pouco assim, um pouco não, bastante, até demais às vezes né (rindo). Eu queria sair com os amigos assim e não podia, ela queria que eu fosse pro lado honesto, que você sabe né, periferia tem muito essa questão de se envolver com o crime e tal, ela sempre queria que eu trabalhasse, aí eu arrumei um serviço de ajudante de mecânico, estudar, essas coisas ela cobrava muito, saber cozinhar, lavar, passar, essas coisas assim.

R: E o seu tio, marido dela, C.?

Pm: A gente não conversava muito não.

R: Era mais distante.

Pm: É.

R: Bom você sai de casa em 95 e quando é que você vem pro abrigo? Primeiro lugar, primeiro e único é aqui?

Pm: Não teve vários.

R: Você ficou em vários

Pm: É que eu nunca gostei assim de abrigos, sabe. Mas eu comecei mais depois que eu voltei a estudar e tal, mas eu já fui no Exército da Salvação, no Projeto Vida, e aqui.

R: Onde você ficou mais é aqui.

Pm: É.

R: Quando é que você chegou aqui? 
Pm: Eu tinha 17 anos.

R: São dois anos atrás.

Pm: Dois anos e seis meses

R: Lá por 2000, ano 2000.

Pm: 2001, março de 2001. Logo quando abriu

R: E o que você acha que fez você ficar parado aqui, na Marly Cury, você disse que não gostava muito mas alguma razão fez você parar aqui.

Pm: Eu acho que foi bem o tempo né, porque chega uma hora que você tem de fazer uma escolha né, todo mundo indo preso e tal, outros se internando na droga, aí você fala: - Ou eu vou por um caminho reto ou eu vou para a esquerda de uma vez. Aí eu optei em seguir reto, pelo mais difícil né, aí eu precisava de algum lugar pra ficar, não ia, quando eu voltei a estudar ainda estava na rua, que eu fiquei um tempo sabe, ia tomava um banho na Igrejinha, ia estudar, voltava, guardava meu material, sabe...

R: Você precisou de um tempo pra voltar pra ficar num lugar, numa casa.

Pm: Tanto que não tinha, não tinha assim opções sabe. Eu queria ficar por aqui, mas só tinha abrigos lá pro centro da cidade.

R: O que você menos gostava nos abrigos?

Pm: Eu não gostava muito assim que...., a maioria , quase todos, você não é tratado como uma....., seria o certo você ser tratado como uma...., tanto que no papel é assim né, você ser tratado como uma pessoa que está enfrentando dificuldades, está em desenvolvimento e tudo aquilo que você puder ensinar pra aquela criança é de bom, ela vai absorver sabe, você é tratado muito como aquela pessoa, ou te vêem como marginal, ou coitado, você não é tratado como uma pessoa que pode fazer alguma coisa, que tem potencial pra desenvolver alguma coisa...

R: Quer dizer lá no Exército você se sentiu assim e no Projeto vida também.

Pm: É e nos outros assim que eu ia lá ..., eu achava assim que não tinha de ser aquela coisa, como se diz, artificial sabe, eu achava que você tinha que ter pelo menos uma ...(?), mas tudo ia ao contrário do que você escolheu sabe, todas as pessoas, todas as conversas, elas iam ao contrário daquilo, eles queriam farra, isso e aquilo, era mais fácil você desistir daquilo do que encontrar motivação para continuar...

R: Isso o pessoal que morava nos abrigos, ou os educadores?

Pm: Tinha alguns que eu conheci...

$\mathrm{R}$ : Eram mais os amigos, ou mais os educadores?

Pm: Assim $70 \times 30$.

$\mathrm{R}$ : E aqui qual a diferença que você...?

Pm: Bom a diferença aqui é em partes assim, eu acho que foi a tia M. e a M.H. sabe, que eu conheço desde criança e você ter assim um laço afetivo com a pessoa né, mesmo que não seja de praxe nesta área de trabalho você criar vinculo afetivo com uma pessoa porque do mesmo jeito que a pessoa ta ali amanhã ela pode não estar mais né e não é legal isso, mas com o tempo assim a gente acabou criando sabe e elas sempre me incentivaram assim, deram a maior força pra voltar a estudar, tia M., tanto que nessa época, logo quando 
abriu aqui eu estudava lá na Casa Verde, ela me dava passe, M. H. comprava passe pra mim me locomover pra escola...

R: Então foi mais essas duas pessoas que fizeram que você se ligasse mais aqui..., você diria que é um dos diferenciais da AMC..

Pm: É foi um dos diferenciais.

R: E você nesta época em que você estava na rua, como foi o seu envolvimento com droga?

Pm: Foi uma coisa assim gradativa né e normal porque é diferente você ter uma visão ridícula de uma coisa que já é banal na sua vida, que no meio em que você vive já é banal, não tem como você ficar indiferente quanto aquilo né.

R: Claro.

Pm: Foi uma coisa que, cedo ou tarde, eu sabia que eu ia estar usando, era só uma questão de tempo, o máximo que eu pudesse jogar pra frente ou ...

R: Mas você chegou a usar muito, chegou a ficar mal de saúde, como foi...

Pm: Eu não cheguei porque assim, eu procurava preencher um pouco o tempo que eu tinha com alguma coisa pelo menos, ou saia pra andar, ou catava o trem ficava indo de Jundiaí até Paranapiacaba (rindo), é porque próprio pra não ter que..., eu acho que foi por causa disso que eu não me viciei em coisas mais pesadas...., porque eu tinha assim a rua não como uma coisa permanente na minha vida, igual outras pessoas que eu conheço até hoje tem isso, porque desde criança só conheceu esse lado, eu não, eu tinha conhecido outro lado, eu sabia que tinha um outro lado, então eu sabia que aquela situação era passageira, ia depender só de mim, o tempo que eu ia levar pra passar por ela, se eu ia prolongar 10 anos, ou reduzir 3 anos é uma coisa, mas você tem que saber que existe um outro lado e procurar conhecer e procurar andar mesmo que seja devagar mas em direção àquilo né.

R: E você estava esperando o que? O que você esperava que acontecesse pra você sair da rua?

Pm: Não, eu....

Pm: Eu não esperava assim porque dentro de mim, é uma coisa até engraçada, eu tinha certeza assim quando eu deitava no chão..., eu tinha certeza que aquilo ali não ia ser pra sempre na minha vida, sabe quando você tem um ideal assim e você fala assim :

- Não, hoje eu estou por baixo mas eu não nasci pra estar por baixo sabe, hoje eu estou...

O telefone toca.....

Pm: Então, aí eu tinha aquilo em mente que eu não tinha nascido pra aquilo, é uma questão de você se enxergar sabe, se você se enxerga ladrão você não vai ser outra coisa, se enxerga honesto ou se você se enxerga grande nunca você vai ser pequeno e se você se enxerga pequeno nunca você vai ser grande e eu não conseguia me enxergar como um moleque de rua sabe, não conseguia me enxergar se tornando adulto e naquela mesma vida, eu não conseguia ver isso sabe, eu não conseguia me entregar, sabia que uma hora iria acontecer, só dependia de mim, uma hora eu ia sair daquilo, aquilo não ia ser pra sempre sabe , eu não ia terminar naquilo.

R: E aí aos poucos você foi retomando a escola e os amigos.. 
Pm: Foi muito difícil, é uma luta né, até hoje, até hoje é uma luta, só que você tem de ir de cabeça erguida né meu, porque...

R: Me fala uma coisa Paulo e com relação a namoro, família, essas coisas, como é a história, o que você pensa, você está namorando, já namorou...?

Pm: Não eu tenho uma coisa comigo, eu coloquei na minha mente assim, enquanto eu não conseguir alcançar o que eu quero eu não vou me preocupar com isso sabe, tanto em constituir família, não primeiro eu quero me estabilizar, primeiro eu quero pensar um pouco em mim, porque se eu morrer amanhã o que eu vou deixar? Minha passagem no mundo vai ser em vão? Vai estar em branco ou vai ter alguma coisa escrita? Sabe eu procuro pensar mais nisso, porque até mesmo por uma questão de prevenção, de você proteger seu ...? , porque olha só, muitas vezes você se envolve com uma pessoa vai mais a fundo e tal, acaba engravidando a pessoa, ali você não planejou aquilo sabe e aquilo que você já tinha planejado anteriormente? Você vai ter de ou congelar por um tempo ou desistir e, não é isso que eu quero fazer sabe..

R: Você já teve namorada?

Pm: Já.

R: Tinha sexo e tudo?

Pm: Tinha mas sempre prevenido né (risos acanhados), eu gosto de me prevenir assim, mas eu não sou uma pessoa que gosta de criar um vínculo afetivo assim com ninguém sabe, não gosto, porque eu já tive vinculo afetivo com pessoas e depois de uma hora pra outra eu tive que desfazer aquilo e é ruim e, eu fico imaginando se uma pessoa criar um vínculo comigo e ter de desfazer aquilo de uma hora pra outra, a pessoa vai ter de passar aquilo que eu passei. Aquilo não foi bom pra mim, se não é bom pra mim, não é bom pra ninguém né, eu não gosto de prolongar relacionamentos....

R: Por enquanto você...., mas se surgir uma namorada que te interessar você acha que você vai evitar ou pode ser que você se balance?

Pm: Ah não, eu vou evitar como já evitei e evito muito esta questão de se envolver sentimentalmente..

R: Sei mas você tem um contato grande com o pessoal daqui...

Pm: É mais com a tia M. e a M. H., desde criança assim elas...

R: A M. continua aqui?

Pm: Continua, é que elas desenvolveram um papel assim em minha vida que até então eu não conhecia sabe, tipo assim, a minha tia fez de certa forma, mas não foi como elas fizeram sabe, de .... porque eu não acreditava em amor materno entre aspas assim, que elas não são minha mãe, mas essa questão de você ver uma pessoa e falar assim: - Não, essa pessoa hoje ela está assim, mas se eu ajudar ela, ela vai poder mudar, se eu der uma força ela vai conseguir, mesmo que da primeira não consiga, tenta na segunda, não conseguiu, tenta na terceira, não conseguiu, tenta na quarta sabe, eu acho que isso é legal no ser humano, principalmente na adolescência, de ter este estímulo de: -Ó na primeira você não vai acertar, mas nem por isso você vai desistir...

R: Você conheceu a M. e a M. H. quando? Quantos anos você tinha?

Pm: Treze anos

R: Foi logo que você saiu pra rua.

Pm: É dois anos depois 


\section{R: E você conheceu aonde?}

Pm: Lá no outro projeto que tinha no Aprendendo a Viver, a tia M. já trabalhava lá e a M. H. era voluntária.

R: E lá você conheceu, com 13 anos você conheceu? São seis anos, foram figuras muito importantes!

Pm: Esses dois anos que eu fiquei na rua foi um pouco ruim sabe porque eu acabei não tendo muitas forças assim pra lutar, eu tinha aquele ideal, mas nas primeiras dificuldades eu já: - Putz não vai dar certo, vou esperar mais um tempo. Eu não tentava e a tia M. ela foi dando uma força, a M. H., motivando.

R: Ta bom, por hoje eu não tenho mais perguntas, eu tenho mas não quero fazer hoje, queria fazer outro dia se você aceitar. Você quer dizer alguma coisa? Não, então ta. Então obrigado por hoje.

Pm: Risos

\section{Entrevista dirigida.}

R: Bom $\mathrm{P}$ eu vou te fazer umas perguntas e quero você responda também assim..., livre sem censura.

Qual a melhor coisa que já te aconteceu?

Pm: A foi quando eu voltei a estudar, que eu fiquei 5 anos sem estudar, foi uma conquista legal, e quando eu terminei meus estudos esse ano.

R: .....ininteligível....

Pm: É

R: Parabéns. Eu acho que de fato você é uma pessoa que tem, eu escrevi no cartão (de Natal) que você tem inteligência, é uma força tua, acho que você tem de saber que ela pode te auxiliar, se você souber usa-la, é uma força que você tem.

Qual a pior coisa que te aconteceu?

Pm: Ah foi quando minha mãe foi embora né, quando eu tinha quatro anos (?), acho que foi a pior coisa.

R: Quantos anos você tinha?

Pm: Quatro anos.

R: qual a melhor coisa que poderia te acontecer?

Pm: Sei lá entrar numa Faculdade boa, principalmente a que eu quero fazer, eu quero entrar na USP, eu acho que seria uma coisa assim.

R: Qual é a carreira?

Pm: Ciências sociais.

R: O que você acha que isso te daria na vida? 
Pm: Eu acho que seria um impulso inicial para mudar um pouco o estilo de vida que eu tenho, expandir um pouco os horizontes, até por uma questão de conquista mesmo, que é um objetivo assim que eu estou lutando, é mais a questão da satisfação, da realização.

$\mathrm{R}$ : E qual seria a pior coisa que poderia te acontecer?

Pm: Ah!; sei lá, ficar aleijado, ficar numa cadeira de rodas, eu acho que é a pior coisa.

R: Você sabe da estória do gênio da lâmpada? Conhece?

Pm: Sei.

R: Se você encontrasse uma lâmpada e tivesse direito a três desejos, o que você pediria?

Pm: Primeiro eu pediria pra acabar com as guerras né, que essa questão de um querer ser mais que o outro acho que é errado, a fome, pediria pra acabar com a fome no mundo e terceiro pra reunir de novo minha família.

R: Mas se fossem pedidos um pouco mais pessoais assim. Que acabar com a fome, acabar com a guerra é um desejo tipo universal.

Pm: Risos....mais pessoal...., reencontrar minha mãe, ter uma vida estável

R: Estável em que sentido?

Pm: Ah!; financeiramente, não assim eu ser mais que as outras pessoas, eu poder um pouco contribuir com a minha família e morar com as minhas irmãs.

R: Se você tivesse uma ilha deserta, quem você levaria pra morar lá?

Pm: Ah!; eu iria sozinho.

R: Sozinho. Não escolheria ninguém.

Pm: Não.

R: Se você tivesse que ficar morando lá você ia preferir a solidão.

Pm: Se fosse numa ilha sim.

R: E quem você não levaria de jeito nenhum.

Pm: .......não levaria assim as pessoas mesquinhas, que só pensam em si, sabe aquelas pessoas que estão do seu lado e só querem ...., tipo usam a sua amizade pra se auto-promover sabe, essas pessoas mesquinhas, não levaria.

R: Vamos fazer de conta que você está num navio com a sua família..., aí de repente esse navio começa a afundar..., o que você faria se você pudesse salvar só uma pessoa?

Pm: Ah!, eu salvaria minha irmã $C$..

R: Por que razão?

Pm: Porque ele é a única pessoa assim da minha família que a gente tem mais um contato, assim sabe, conversa, tem uma afetividade maior. 


\section{R: E você tem visto ela?}

Pm: Faz uns dois anos que eu não vejo ela.

R: E você sabe onde ela está?

Pm: Sei.

R: Você não está com vontade de procurá-la por enquanto....?

Pm: Não, não é que eu não esteja com vontade, é que eu acho que não é o momento certo.

R: Qual seria o momento certo?

Pm: Ah, .....não sei.

R: Se você ganhasse aquele premio da loteria que saiu outro dia aí, 43 milhões.

Pm: Risos...

R: É muita grana ...,o que você faria com esse dinheiro?

Pm: Ah...!, meu ...eu... não sei..., primeiro lugar eu doaria assim 50 ou $70 \%$ pra algumas instituições e os outros 30 ajudaria a minha família e investiria né, numa poupança, ou em dólar, ouro, uma coisa assim e os $70 \%$ eu dividiria entre algumas instituições.

R: E algum prazer pra você, alguma coisa assim..., não te ocorre?

Pm: Ah...!, é lógico; conhecer o Brasil né, viajar um pouco pelo Brasil.

R: Que mais?

Pm: Ah..., acho que só, é a única coisa que eu quero assim, conhecer outros lugares aqui no nosso País.

R: E você ...,como você vê o resto da sua vida depois de ter ganho o dinheiro? Você iria viver como?

Pm: Ah...!, eu teria uma perspectiva maior de ..., outras lutas né, que no momento hoje minha luta é entrar numa Faculdade, se eu tivesse com esse premio não seria mais aquela luta, que eu teria condições assim, não é que seria mais fácil, mas seria mais simples né, eu poderia pagar uma não teria que ir numa pública, não que..., eu quero fazer mesmo uma pública por que são boas, quero fazer uma Universidade pública porque são de ótima qualidade né, USP, a UNESP, sabe mas, mesmo assim eu... e, eu ajudaria um pouco também o pessoal que trabalha comigo, até a gente comenta (rindo) que se eu ganhasse um premio desse eu daria assim 100 mil pra cada pessoa que trabalha comigo.

R: Você sabe o quanto é 100 mil, o que pra você comprar com 100 mil?

Pm: Não da pra fazer muita coisa né, dá pra comprar uma casinha assim...

R: Quanto você acha que custa essa casa aqui.

Pm: Ah! essa casa custou na época uns 180 mil aproximadamente. 
R: Hoje você acha que valeria quanto?

Pm: Ah! valeria um pouco mais né, uns 200, 210.

R: Você sonha bons sonhos ou sonhos ruins?

Pm: Ah!; bons (com expressão de satisfação).

R: Dormindo

Pm: Bons.....

R: Bons sonhos.

Pm: Não tenho essa coisa de pesadelo não.

R: Não tem.

Pm: Pode contar algum sonho? Tem algum sonho mais comum de você sonhar? Que você gosta mais.

Pm: Ah...., geralmente assim os sonhos que eu tenho assim são mais situações assim sabe, um pouco do cotidiano, ta relacionado tanto que parece um pouco realidade, sabe que eu sonho bastante com pessoas do meio que eu vivo, ou da escola, ou situações engraçadas sabe, que nem uma vez teve um sonho que foi legal, eu acho que eu sonhei umas três vezes esse sonho, que eu tipo tava nadando, só que eu não tava nadando na água, eu tava nadando na nuvem sabe, aí eu olhava pra baixo:

- Nossa eu tenho que nadar mais rápido porque senão eu caio, sabe um sonho bem engraçado e depois eu pensei: - To sonhando.

R: Você tava voando e a sensação foi agradável....., foi engraçado ou foi..., qual foi a sensação?

Pm: Ah!; foi mista assim né, de alegria e aquela coisa de ser algo novo ali, que você nunca experimentou, sabe quando você experimenta uma coisa pela primeira vez? Acho que foi isso.

R: O que imagina que você vai fazer quando você for adulto? ...Como você imagina sua vida de adulto?

Pm: Ah!; sei lá, continuar trabalhando, estudar, escrever, que eu gosto bastante de escrever, seguir assim um pouco na literatura que eu gosto bastante, literatura e ter uma vida normal

R: Você pensa em casar?

Pm: Ah!; não no...., sei lá...., eu não sou muito a favor de casamento, eu acho que o casamento de certa forma, ele contribui pra ..., pra quebra assim do amor sabe, não sei, mas a maioria dos relatos que eu vejo acontece dessa forma, as pessoas se gostam tal, se amam, aí ta aquela maravilha, aí vai morar junto, aí começa a destruir, entendeu, começa aquela cobrança e muitas vezes a pessoa não ta preparada, eu acho que é uma...., o casamento faz parte da existência, mas você tem de estar preparado, no momento certo, com a pessoa certa, e mesmo assim é complicado, são poucos os casos que as pessoas, sabe, passam anos. 
R: Você imagina que você possa viver sozinho o resto da sua vida?

Pm: Ah...!, ninguém consegue viver sozinho, né...

R: Sozinho eu digo sem uma parceira, sem uma companheira, porque você pode não quere casar, mas querer viver junto, não sei se é nesse sentido que..., ou pode ter relações que..., não precisa ter uma pro resto da vida, pode ter umas né, ou enquanto duram...

Pm: Ah não, mas eu acho que é uma pessoa mesmo, é que eu ainda não encontrei, mas não assim pra viver numa prisão sabe, tem de ser uma coisa livre, a pessoa tem de ter a liberdade, a partir do momento em que um não está mais fazendo o outro feliz, ter a liberdade de procurar a sua felicidade, sabe, não aquela coisa..., aquele círculo vicioso, aquela prisão, isto que destrói os sentimentos.

R: E filhos, o que você pensa de filhos?

Pm: Ah!; eu quero né, ter uns, uns dois, casal, ou três, sei lá.

R: Você deve conhecer como se dá a fecundação de um óvulo, você deve ter estudado isso, espermatozóide, óvulo, gestação, tudo isso é reconhecido por você?

Pm: É.

R: Você já teve sexo...., relações sexuais?

Pm: Já..., várias..

R: Várias...

Pm: É.

R: E como você se sente em relação ao sexo? Você fica a vontade, você gosta, você não gosta? Fica meio acanhado? Gosta mais das mulheres de que tipo?

Pm: Eu (risos), eu gosto mais das mulheres mais reservadas, cultas, essas que chamam mais minha atenção...., não essa pessoa que, não sei por que mas eu acho muito interessante essa questão da corte, você chegar, cortejar uma mulher ali, eu acho que isso impulsiona mais aquele desejo de você estar junto da pessoa, porque quando você chega e fala assim: - Oi tudo bom? ...e já ficaram junto isso não é legal, eu acho que quanto mais difícil assim, mais, sabe, mais inteligente a mulher é, mais culta, porque eu gosto bastante de conversar e então é muito chato você estar do lado de uma pessoa que você não tem assunto, que não pensa da mesma maneira que você, ou não enxerga o mundo mais ou menos daquele jeito que você enxerga, né, eu acho que isso é o que me atrai mais.

R: E você prefere as mais velhas, mais novas, alguma faixa de idade, ou não?

Pm: Ah...., eu acho que, não assim bem mais velha, mas um pouco mais experiente, assim tipo 5 anos, 3 anos.

$\mathrm{R}$ : $\mathrm{E}$ você se sente à vontade em relação a sexo ou se sente inibido?

Pm: Não... 
R: Então ta. Acabamos P. (risos).

\section{HTP e desenhos livres.}

R: Bem P., pleno domingo e eu aqui te enchendo o saco e você foi dormir tarde, mas eu tenho prazo e quero escrever este livro e você é um dos personagens deste livro. Bem hoje eu quero que você faça uns desenhos e conte umas estórias da sua imaginação, em cima..., depois do desenho feito, não é pra avaliar se você sabe desenhar ou não, é simplesmente pra você fazer um desenho e depois criar uma estória ...pode ser? Você pode usar o que você quiser, lápis de cor, borracha, tem tudo aí e eu queria primeiro que você fizesse um desenho qualquer, livre, o que você quiser, simples, complicado, do jeito que você desejar...

R: Ta pronto? ...É um rosto...Então, assim, na imaginação...Esse rosto é de alguém?

Pm: Não, não que eu conheça.

R: Se você fosse criar uma estória, seria de alguém?

Pm: É poderia ser né!!

R: De quem poderia ser, um homem, uma mulher?

Pm: Sei lá um homem.

R: Que idade mais ou menos.

Pm: Ah!; uns 20, 22 anos.

R: O que esse cara faz P.?

Pm: Ah!....

R: Solta a imaginação...

Pm: Ah!; sei lá, poderia ser um pintor, desenhista...

R: Você quando costuma fazer desenho, você costuma desenhar rostos assim?

Pm: É a maioria das vezes, é que eu gosto de um pouco desenhar expressões.

R: Expressões.

Pm: É.

R: Como você descreveria o temperamento deste sujeito? O que ele sente, o que ele pensa?

Pm: Ah!; ele é uma pessoa calma, ...é uma pessoa calma assim que... por mais que fazem de tudo pra atrasar o lado dele ele mantém a calma..., uma pessoa calma...

R: O que você diria que você tenta mais passar nesse desenho?

Pm: Ah eu acho que é o olhar da pessoa né, tipo olhando pro nada assim, olhando pro futuro.

R: Olhando pro futuro.

Pm: É

R: Mas o futuro aqui é um nada!!!!?

Pm: É..., ele ainda não existe né, ainda é uma hipótese... 
R: Quer dizer, ele não sabe direito o que escolher, seria isso?

Pm: Não, até que saberia, não sabe...o que acontecerá com essas escolhas né...

$\mathrm{R}$ : Ele se sente bem, ele se sente adoentado?

Pm: Ele se sente bem..., (risinho) muito bem.

R: E ele tem família?

Pm: Não.

R: E qual seria o futuro pra ele, que você acha que seria legal pra ele?

Pm: Ah! sei lá... estudar, continuar fazendo o que ele gosta, né !?

R: E o que seria ruim pra ele?

Pm: Ah..., ter de viver onde ele vive.

$\mathrm{R}$ : E ele vive aonde? O que você imagina?

Pm: Ah..., ele vive aí na rua.

R: É um homem né?

Pm: Sim.

R: Você quer falar mais alguma coisa dele?

Pm: Não.

R: P. eu queria que você desenhasse agora uma casa..., como você quiser, com paisagem sem paisagem, do jeito que...

R: Pronto? Assim na imaginação, quem mora nessa casa?

Pm: Ah..., ninguém...

R: Ninguém. A casa ta vazia?

Pm: É.

R: Ta pra alugar?

Pm: Não... ta vazia só.

R: Vazia... e cadê as pessoas?

Pm: Ah! sei lá, tão dispersas, cada um ta no seu canto.

R: Cada um no seu canto... e faz tempo que eles se dispersaram dessa casa? Ela ta vazia há muito tempo?

Pm: Sim..., bastante.

R: Quanto tempo mais ou menos?

Pm: Ah sei lá...., alguns anos.

R: Alguns anos... E o que aconteceu com as pessoas? Por que se dispersaram? Quais os motivos?

Pm: Ah!; sei lá, porque é complicado viver muita gente no mesmo lugar.

R: Então morava muita gente nessa casa?

Pm: Umas 5 pessoas assim.

R: Quem morava aí?

Pm: Cinco amigos. 
R: Cinco amigos. Homem, mulher?

Pm: Homem.

$\mathrm{R}$ : Todos homens. Que idade mais ou menos?

Pm: Ah! tudo entre vinte e vinte e cinco anos.

R: E aí eles estão aonde agora?

Pm: Não sei, cada um foi pro seu canto..., buscar a sua vida né.

R: E deixaram a casa aí...

Pm: Sim.

R: Você não acha desperdício?

Pm: É, não, mas periodicamente um vem pra ..., acender o fogão de lenha né...

R: Ah..., eu tava vendo esse fogão de lenha aí. Qual é a história desse fogão? Porque tem uma fumacinha saindo da chaminé da casa.

Pm: É.

R: Tem uma luz acesa. Alguém deve passar aí.

Pm: Cada dia assim um vem e tal e cuida dela, pra ela não ficar vazia, e coloca lenha na fogueira, no fogão pra ele não enferrujar.

R: Pra ela não deteriorar, mas ninguém ta aproveitando a casa, ninguém ta comendo na casa, nem dormindo na casa. Eles estão esperando alguma coisa acontecer pra usar essa casa?

Pm: Não, acho que nem querem mais ela.

R: Não querem mais !?

Pm: Não.

R: Mas mesmo assim eles estão cuidando da casa, quer dizer é um sentimento de amor e de ódio.

Pm: É mas acho que mais visando o lucro pra poder, se eles forem vender ela (risos).

R: Ah entendi.

Pm: Pra ela não ser invadida.

R: O que você acha que ta faltando nessa casa, pra poder ajudar...

Pm: Ah! sei lá acho que mais conversa né...

R: Tinha alguma coisa de bom nessa casa?

Pm: Não, nada.

R: Nada..., então a casa taí e ela não vai ser mais..., o futuro dela qual é?

Pm: Ah! vender né, vender e dividir o valor.

R: Você quer falar mais alguma coisa dela?

Pm: Não.

R: Bom P. desenha uma árvore pra mim.

R: Essa arvore está localizada..., parece assim um campo grande né? 
Pm: É.

R: Aqui são umas montanhas, uma planície, e aqui pro lado ela ta sozinha, tem outras árvores?

Pm: Tem outras árvores, tem outras plantas.

R: Ta, paisagem assim como ela..., tem outras..., ela não ta..., não é uma das poucas...

Pm: Não.

R: E ela...., como você descreveria esta árvore?

Pm: Ah!; sei lá, uma arvore com um tronco forte, resistente e que dá fruta.

R: Que fruta que ela dá?

Pm: Ah!; poderia ser laranja, uma laranjeira.

$\mathrm{R}$ : E algumas pessoas..., tem gente que se aproveita dela ou ela ta num canto vazio, sem gente...?

Pm: São poucas as pessoas, mais as pessoas que passam por aí, que é no mato.

R: Ah!; são só os transeuntes, quem passa de vez em quando, ela não ta perto de uma fazenda, de uma casa, que alguém ta sempre lá, pegando laranja dela nem nada...

Pm: Não.

R: Quantos anos você daria pra essa árvore?

Pm: Uns 20 anos...

R: É antiga...

Pm: É.

R: Qual o futuro dela?

Pm: Ah..., acho que ela não tem futuro, ela vai ficar aí, porque ela não se locomove...

R: Ela ta saudável?

Pm: Ta.

R: Quantas vezes por ano ela dá fruta, você sabe?

Pm: Duas vezes por ano, de 6 em 6 meses.

R: Mas isso é uma informação que você sabe, que as laranjeiras todas dão, ou essa que é assim.

Pm: Não acho que é essa daí porque geralmente essas arvores dão fruto uma vez por ano.

R: Ah é? É que eu não sei, não conheço. Falta algum,a coisa pra essa árvore?

Pm: Sei lá acho que não.

R: Não..., quer falar mais alguma coisa dela?

Pm: Não.

R: P., me desenha agora uma pessoa.

R: Me fala um pouco dessa pessoa, é homem ou mulher? 
Pm: Homem.

R: Qual a idade dele?

Pm: Ah, uns 14 anos, 15 anos.

R: Me fala um pouco dele, quem ele é, onde ele mora, o que ele faz, o que ele gosta.

Pm: Ah...

R: Fala da imaginação...

Pm: Ah! sei lá, acho que ele mora lá no Taboão da Serra, é uma pessoa trabalhadora e acho que só.

R: E tem família?

Pm: Tem.

R: Mora com a família?

Pm: Não.

R: Mora aonde?

Pm: Mora com uns tios.

$\mathrm{R}$ : Com uns tios. E com que ele trabalha?

Pm: Trabalha na feira.

$\mathrm{R}$ : E ele tem amigos?

Pm: Tem bastante...

R: Tem bastante. Gosta dos amigos?

Pm: Gosta.

R: E como você diria que é o temperamento desse camarada.

Pm: Ah, acho que é uma pessoa calma, só que quando fica nervosa, sai quebrando tudo.

R: Quebra tudo.

Pm: É.

R: Ofende as pessoas?

Pm: Também, assim como é ofendido né.

R: E o que ele acha do físico dele, se sente saudável, gosta do físico?

Pm: Gosta.

R: E tem alguma doença, já teve?

Pm: Não.

$\mathrm{R}$ : E ele namora.

Pm: Sim.

R: E como é a relação que você imagina?

Pm: É mais aquela relação infantil (risos), mais aquela coisa mais de amizade e tal.

R: Ele gosta da namorada? 
Pm: Sim.

R: E quantos anos tem a namorada?

Pm: A mesma idade.

R: E você acha que esse namoro deles vai durar, ou vai ser rápido.

Pm: Acho que namoro de adolescência sempre passa né.

R: Passa rápido...

Pm: É.

R: Que esse cara tem de bom?

Pm: Acho que é uma pessoa esforçada.

R: Qual a fraqueza dele?

Pm: Nenhuma.

R: Nenhuma, nenhum defeito?

Pm: Não que ele conheça.

R: Queria que você me fizesse agora um desenho do sexo oposto.

R: Quantos anos tem essa menina P?

Pm: Uns 18 anos.

R: $18 \ldots$, o que ela faz?

Pm: Só estuda.

R: E como é a vida dela, ela mora com a família?

Pm: A mãe dela é falecida, ela mora com as irmãs.

R: Com as irmãs..., a mãe morreu e o pai?

Pm: O pai também.

R: Também morreu.

R: E o que ela está estudando?

Pm: Ela está terminando o colegial, não sei o que pensa em estudar depois.

R: Como ela se dá com as irmãs?

Pm: Bem.

R: E me fala uma coisa, como é essa menina com os homens, como é a relação dela com os homens?

Pm: Putz..., ah sei lá, acho que mais assim inocente, ela não é uma pessoa maliciosa,_é uma pessoa pura.

R: Ela namora?

Pm: Não.

R: Nunca namorou?

Pm: Não.

R: Ela é religiosa?

Pm: Não. 
R: E será que ela sente que namorar é pecado? sexualidade?

Pm: Não, acho que ela não achou a pessoa certa.

R: Como seria uma pessoa certa pra essa menina?

Pm: Ah!; sei lá, uma pessoa que respeitasse ela, que compreendesse.

R: E o que falta pra essa menina?

Pm: Ah!; conhecer mais pessoas né, sair um pouco do ambiente.

R: Você acha que ela tem uma vida restrita. E o que ela deveria freqüentar assim, que o ela deveria buscar?

Pm: Ah!; não sei, passear mais, ir ao cinema, ao teatro.

R: Ela quer casar?

Pm: Quer (risos), toda mulher quer.

R: E ela gosta dela fisicamente, ou não...

Pm: Ah não né, mulher nunca ta satisfeita com o que tem né (risos), sempre se espelha nas outras.

R: Ela é saudável?

Pm: É.

R: Você quer falar mais alguma coisa dela.

Pm: Não.

R: Então P. um ultimo desenho. Desenha de novo qualquer coisa, um desenho livre, pra finalizar.

R: Jóia. Fala um pouco disso aqui.

Pm: É onde eu morava lá em C..

R: Ah, era assim.

Pm: É, tinha nossa casa aqui, tinha um poço, tinha uns pés de goiaba, lá tinha bastante pé de cana, e bem no fundo assim tinha um rio.

R: O que gostoso hein...

Pm: É.

R: E qual é o sentimento que isso te dá?

Pm: Acho que na época eu não gostava de lá não, que lá era muito parado (risos), e eu já tinha acostumado aqui em São Paulo. Eu não gostava de lá mas hoje em dia eu tenho saudade, chega uma hora que uma calmaria é bom.

R: Olhando pra cá você sente calmaria e que mais? Olhando pra cá o que mais te faz sentir, te evoca?

Pm: Acho que é mais um lugar de sossego, de descanso.

R: É um lugar amplo né. Que mais você diria desse lugar, o que falta nesse lugar?

Pm: Ah!; não tem mais coisa né, tem mais casas pra cá e tal.

R: Sim mas,isso (o desenho) foi o que coube no papel...O que há de mais legal nesse lugar, a qualidade dele. 
Pm: Ah!; a qualidade é o sossego, que é uma cidade calma, um monte de gente..., até o irmão de um colega meu que trabalha comigo foi morar lá, é assim, é um pouco complicado em matéria de emprego. Ou você trabalha assim nas plantações né, porque lá tem plantação de laranja e de cana de açúcar, ou você trabalha na cidade, não tem muita possibilidade de emprego, quer dizer na época, hoje em dia eu não sei.

R: Hoje pode estar diferente.

Pm: Há 10 anos.

R: E você acha que você ficaria feliz voltando pra morar num lugar assim?

Pm: Ah não, pra morar num lugar assim eu não quero mais, é mais pra passear.

R: Por que você não quer?

Pm: Porque eu já acostumei com São Paulo né..., aqui é um pouco mais fácil.

R: Em que sentido?

Pm: No sentido de trabalho né, tem mais oportunidade assim de crescer né, você ta num lugar hoje, mas você pode se especializar e ir pra um lugar melhor e tal.

R: Nesse canavial não tinha cobra não?

Pm: Tinha, tinha um monte. Tipo assim, o pessoal entrava lá mas só que antes de cortar a cana eles queimam né, aí morrem as cobras, o que eles vão deixar crescer, eles tem que queimar, é próprio para matar esses bichos e secar um pouco a cana.

R: Entrar no canavial verde é pedir pra ser picado.

Pm: É, é perigoso, mas o pessoal que trabalha aí vai preparado né.

R: Vai de bota.

Pm: Não, eles não colocam bota, colocam uns negócios, se amarram todo, se enchem de panos, um monte de proteção.

R: No braço também.

Pm: É no braço, na perna.

R: Cobra venenosa.

Pm: Tem venenosa..., a maioria não que é próximo do rio, cobra d'água geralmente não é..., mas tem coral.

R: Legal..., quer falar mais alguma coisa? Então ta bom, esse foi o último de hoje. 


$$
\text { c }
$$




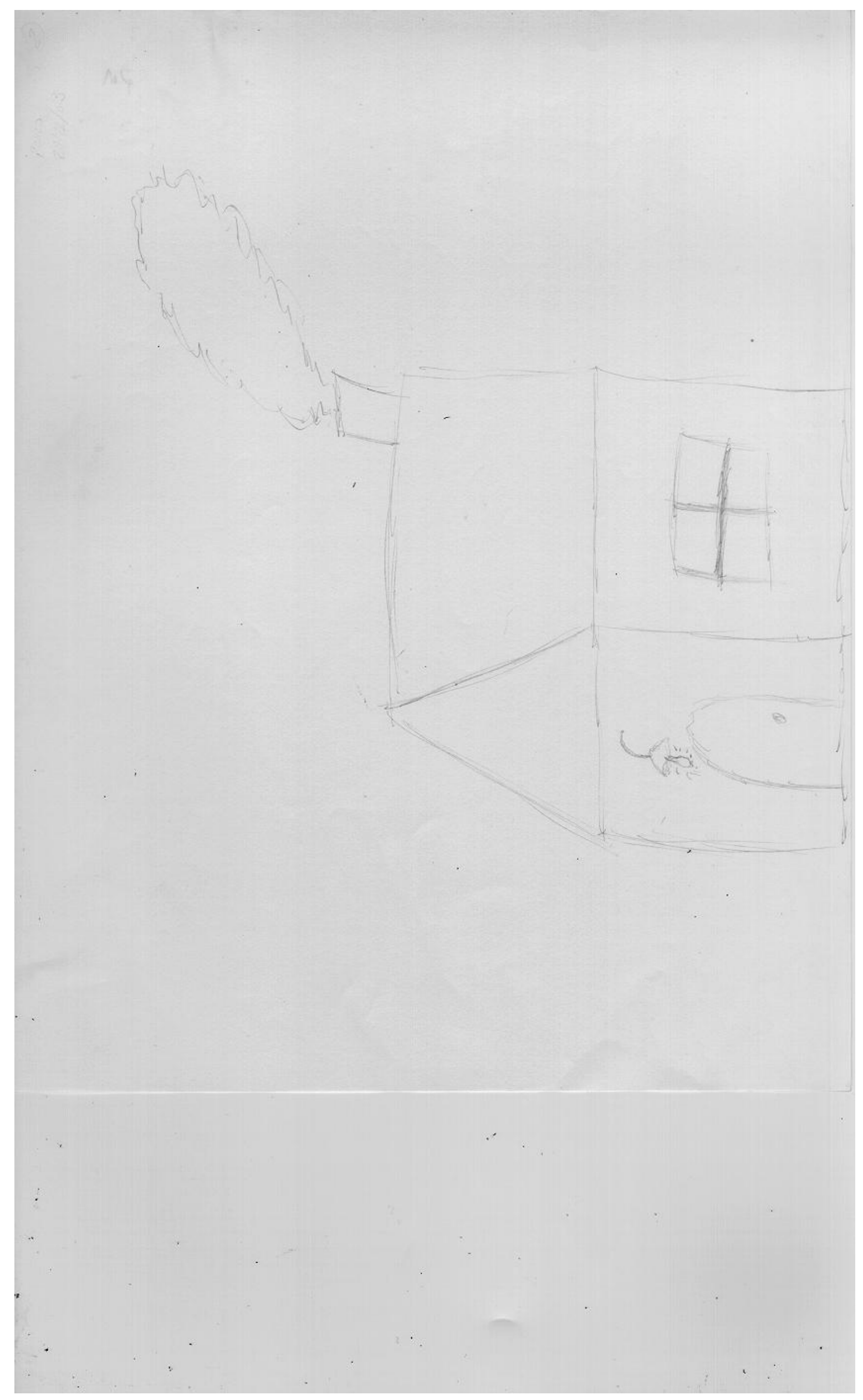




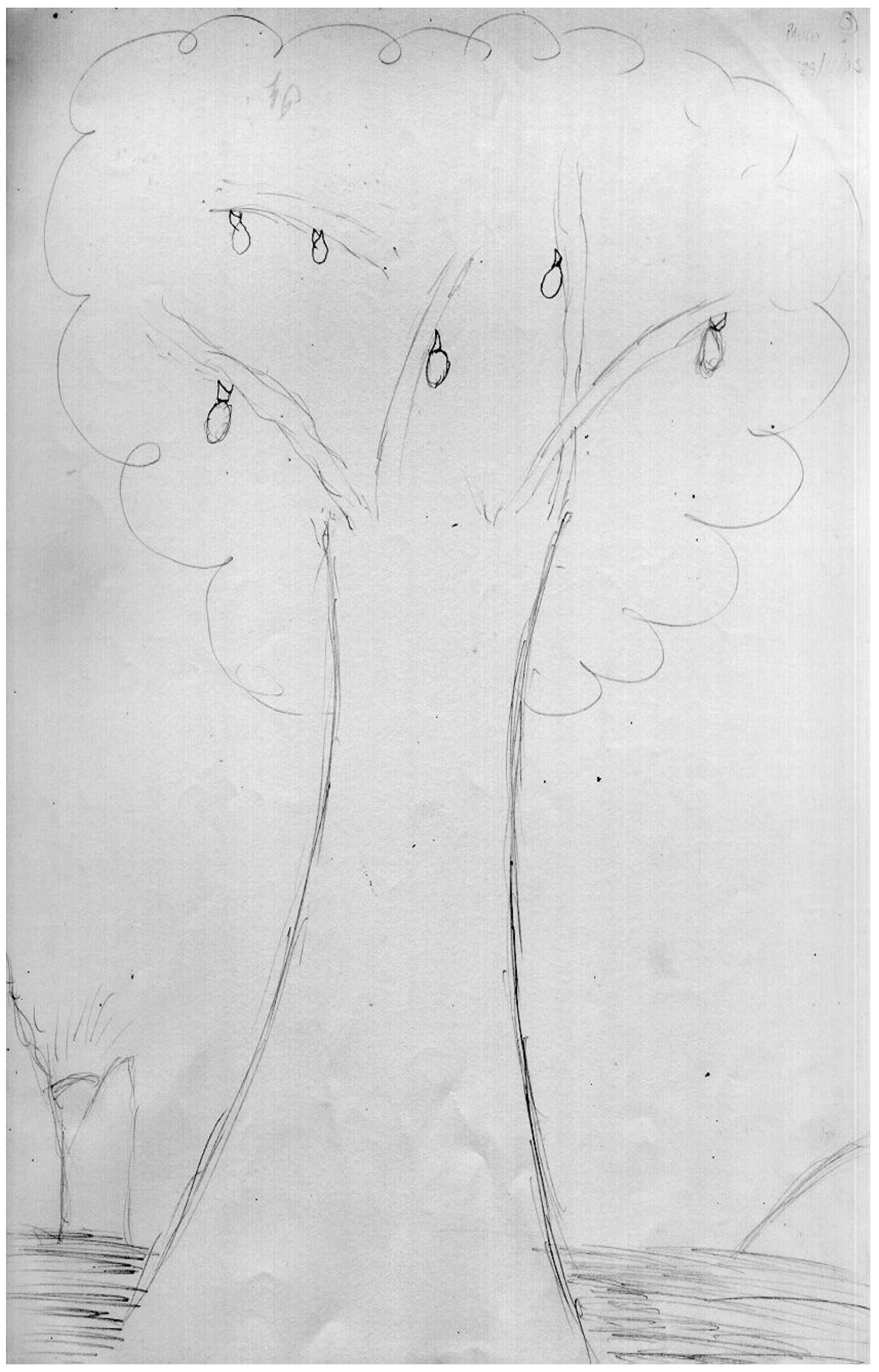




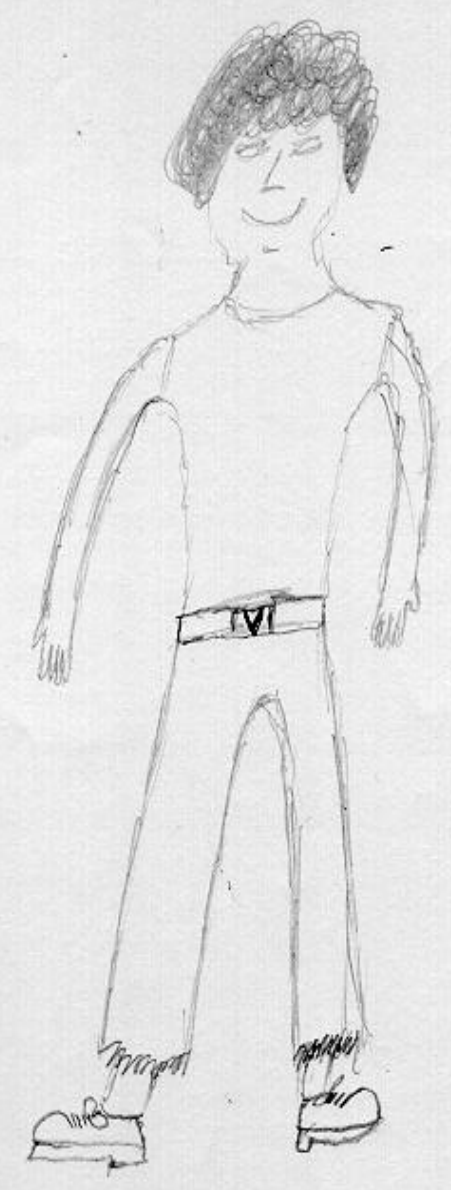



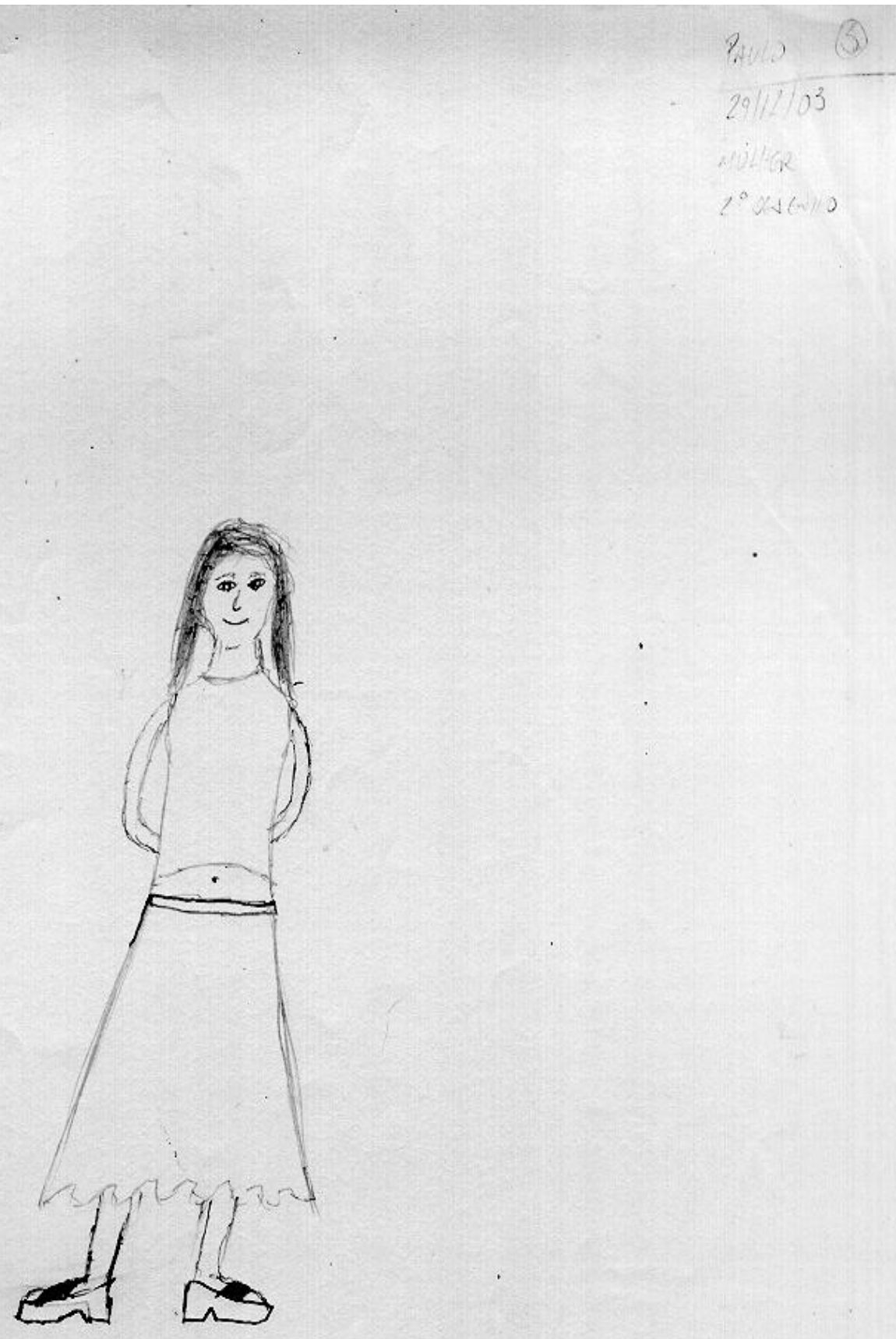


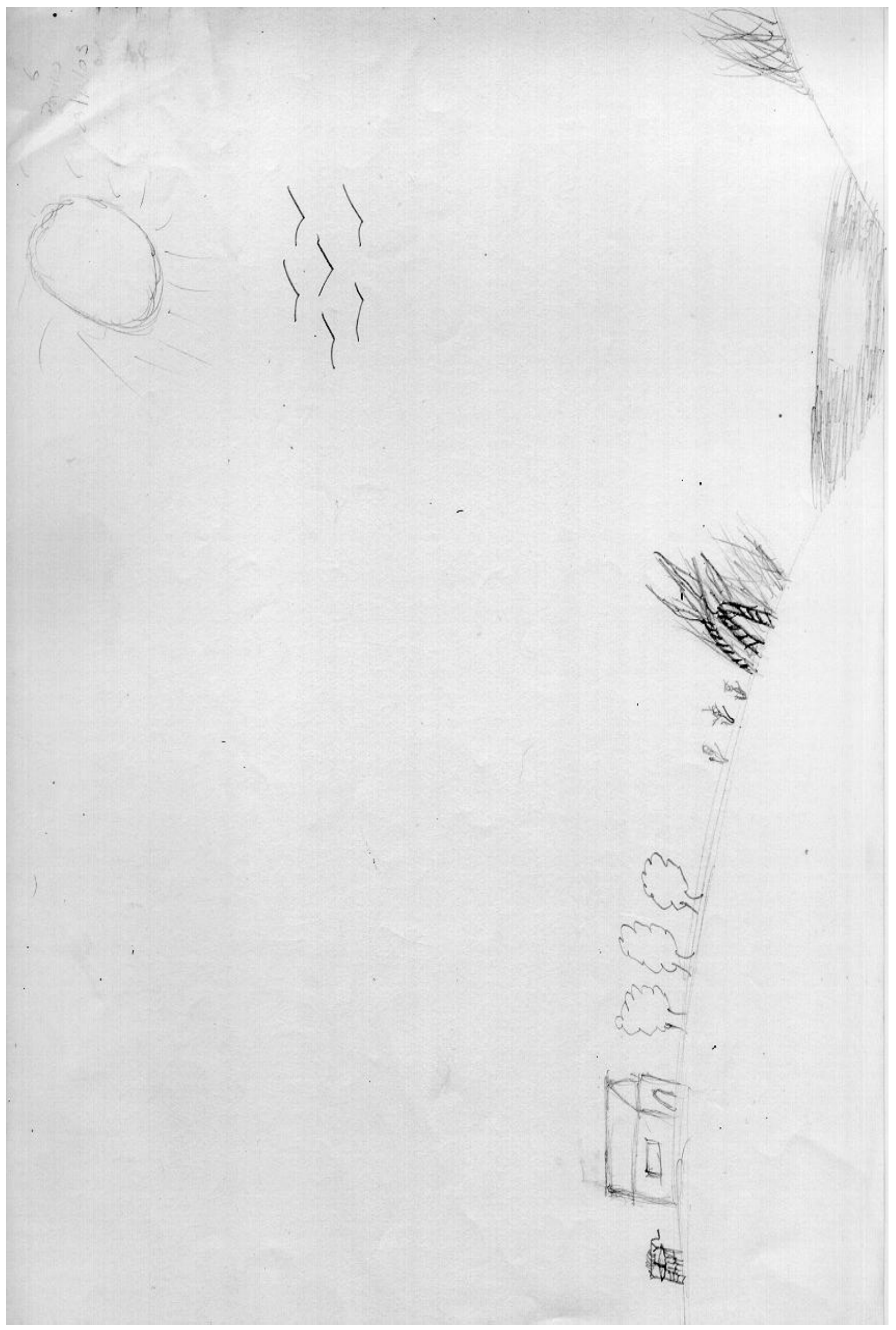




\section{TAT}

R: Então P. continuando aqui o nosso trabalho venho eu mais uma vez encher o seu saquinho (risos) pra gente acabar com esse livro, aí você vai ver sua estória lá no livro, uma contribuição pra sociedade, falta pouquinho, hoje e mais um dia só e a gente mata, certo.

Então hoje P. é dia 29 de dezembro de 2003 e eu vou mostrar pra você umas figuras, e aí vou querer que você também solte sua imaginação, você olhe para as figuras e deixe vir na sua cabeça o que quiser, o que aparecer, sem se preocupar com censura, é uma estória de faz de conta, certo. Então eu quero que você olhe e vá me contando o que você vê nessa situação, nessa figura.

\section{Prancha 1}

Pm: Ah!; aqui parece que..., é tem um menino com um violino e parece que ele não sabe tocar e ta querendo aprender.......

R: Certo....., o que aconteceu antes dessa situação?

Pm: Ah!; ele poderia ter ganhado o violino de presente, tem até um papel aqui, só que ele não sabe tocar.

R: E onde ele está?

Pm: No quarto dele.

R: E como você acha que essa situação vai continuar?

Pm: Acho que ele vai procurar aprender tocar né, que ele já ta com o violino, porque não aprender?

R: Você diria que a expressão dele é do que?

Pm: Ah!; é mais de ...., tipo assim, ele quer fazer alguma coisa e não sabe como fazer entendeu?

R: Certo.... de desafio, digamos assim!!!!?

Pm: É.

R: E como você acha que vai acabar?

Pm: Ah!; eu acho que ele vai estudar violino e vai aprender a tocar.

R: Vai acabar que ele vai realizar..... Quer dizer alguma coisa mais?

R: Prancha 3MF, eu falo porque é o número que ta aqui, só pra identificar. Que história você vê nessa situação aí?

Pm: Uma mulher chorando né, ela poderia ter brigado com alguém que ela gostasse muito e chegou em casa toda triste, vindo de algum lugar como se fosse uma festa, ela ta bem vestida.

R: Você acha que ela poderia estar numa festa?

Pm: É e algo a decepcionou.

R: Que coisa poderia tê-la decepcionado?

Pm: Ela poderia ter brigado com o namorado dela. 
R: Qual a razão pra ela poder brigar?

Pm: Ah!; poderia ter sido ciúmes.

R: E em que estado você acha que ela se encontra agora, o que está acontecendo na cabeça dela?

Pm: Acho que ela está um pouco confusa, triste assim, chorando.

R: E como você acha que vai solucionar isso?

Pm: Ah!; não sei, bom ela poderia conversar com a pessoa.

R: E o que mais você acha que vai acontecer? Põe a imaginação.....

Pm: Acho que ela vai ficar chorando um bom tempo.

R: E como vai terminar a estória?

Pm: Ela indo lá procurar a pessoa.

$\mathrm{R}$ : E eles vão se entender?

Pm: Vão.

R: Mais alguma coisa?

R: Prancha 7RH. O que você vê aqui?

Pm: Um pai e um filho.

R: E o que está acontecendo aí, entre os dois?

Pm: Ah!; sei lá, acho que o pai ta querendo que ele faça alguma coisa, ou que ele estude, ou que ele seja alguma coisa que ele não quer ser.

R: Ele não está afim do que o pai está querendo.

Pm: Não.

R: E o que o pai está querendo?

Pm: Talvez que ele siga a mesma profissão que o pai.

R: E o que está acontecendo com o filho para ele recusar?

Pm: Acho que ele quer descobrir as coisas por ele mesmo, não se espelhar no pai.

R: Como é o temperamento desse pai e desse filho?

Pm: Ah é um temperamento normal, sendo que ele obedece o pai, mas nesse momento ele já está grande e tal, não acha necessário mais seguir tudo aquilo que o pai fala.

R: E como você acha que vai se resolver essa situação?

Pm: Cada um vai seguir o seu caminho.

R: Em paz ou....com conflito?

Pm: Não, em paz.

R: Em paz...O pai aceita a independência do filho. Qual a idade que você daria pra esse cara? O rapaz.

Pm: Uns 25 anos. 
R: Ok. Prancha 8RM. O que você vê aqui nessa prancha?

Pm: Alguém matando uma pessoa né.

R: Que mais?

Pm: Só né. Como se fosse o espírito da pessoa saindo...

R: Qual é o espírito?

Pm: Esse carinha aí...

R: Então quer dizer, quem ta aqui é essa pessoa.

Pm: É.

R: E por que essa pessoa foi morta?

Pm: Não sei.

R: Você acha que foi injustamente, ou teve motivo?

Pm: Injustamente, não é justo ninguém matar ninguém. É sempre uma injustiça.

R: E qual a razão, os motivos de quem está matando?

Pm: Sei lá, acho que eles poderia ter se envolvido em crime.

R: Eles quem?

Pm: Ele com esse dois caras do lado.

$\mathrm{R}$ : Ah!; ele e mais os dois

Pm: É estão matando pra não deixar prova né.

R: Queima de arquivo.

Pm: É.

R: Esses dois aqui então são amigos

Pm: É

R: E com você acha que vai acabar essa estória?

Pm: Ah!; a policia chegando ou eles matando a pessoa e jogando o corpo no rio, enterrando.

R: Mas qual das estórias? Vão jogar o corpo?; a policia vai chegar?; dá pra decidir por uma?

Pm: Jogar o corpo.

R: Jogar o corpo...e eles vão sair livres dessa situação?; os bandidos vão sair impunes?

Pm: Sim.

R: Mais alguma impressão?

Pm: Não.

R: Então vamos pra próxima. Prancha 9RH. E aqui o que você vê? Conta uma estória pra gente. 
Pm: Poderia ser 4 amigos, sei lá, que tavam andando no meio do mato, fazendo uma trilha, e eles pararam pra descansar.

$\mathrm{R}$ : De onde eles estavam vindo?

Pm: Sei lá, tavam descendo a serra, poderia ser a Serra da Mantiqueira, algum lugar assim no meio do mato.

R: Qual a razão dessa trilha?

Pm: Divertimento né, todo mundo vai acampar por diversão.

R: E você diria que esse é o momento do descanso.

Pm: É.

R: Como eles estão se sentindo aí?

Pm: Ta um pouco desconfortável né...., no meio do mato.

R: E como vai se desenvolver essa estória?

Pm: Ah!; eles vão descansar um pouco, vão acordar e vão seguir o caminho deles.

R: Mais alguma coisa?

Pm: Não.

R: Ta bico não ta?; 13 HF. E aqui o que você vê?

Pm: Uma pessoa chorando né.

R: Quem é essa pessoa?

Pm: Poderia ser o marido dessa mulher que está deitada né?

R: E qual o motivo do choro?

Pm: Ela poderia ter morrido ou estar doente, em coma, com doença incurável...

R: Ele está lamentando...

Pm: É..., ela está muito doente.

R: O que aconteceu antes..., pra ela adoecer...?

Pm: Ah!; não sei, poderia ter pego uma tuberculose, uma doença assim, que deixa ela de cama, aí ele está com medo que ela morra.

R: Sei....E o que vai acontecer?

Pm: Ah!; ela vai morrer né, se é uma doença assim incurável.

R: No caso é uma doença incurável que ela tem. E o que vai ser dele depois que ela morrer?

Pm: Ah!; ele vai viver a vida dele né, procurar outra pessoa e tentar superar.

R: Mais alguma coisa?

Pm: Não.

R: Prancha 14.

Pm: . Tem um rapaz olhando pra lua. 
R: Pra lua?

Pm: É

R: Lua ou rua?

Pm: Lua. ....É noite, tipo assim ta escuro e ele não consegue dormir, ta com insônia, aí ele sentou na janela e ficou admirando o luar.

R: Por que ele não consegue dormir?

Pm: Ah!; porque ele está com uns problemas assim sabe, dívida, então ele não consegue dormir direito.

R: E essa casa onde ele está é onde?

Pm: É onde ele mora, a casa dele.

R: E aí, depois como vai terminar?

Pm: Aí ele vai ficar acordado até quase o dia amanhecer, aí vai bater o sono e ele vai voltar a dormir.

R: Mais alguma coisa?

Pm: Não.

R: Agora essa aqui, prancha 16, que você vê ai.

Pm: Poderia ser um monte de neve né!!!?

R: Neve!!!!?

Pm: É.

R: E o que está acontecendo nessa neve, vamos criar o que você quiser ai, coloca o que você quiser nessa...

Pm: Poderia estar acontecendo uma chuva de neve e o pessoal esquiando, um lugar assim bem bacana.

R: Onde por exemplo?

Pm: Nos Alpes, ou senão poderia ser no Pólo Sul né....., lá em Comandante Ferraz, lá nas bases quando vem aquelas tempestades de gelo que você não vê nada, ou no Everest, num lugar assim....

R: Quem são as pessoas que estão aí?

Pm: Ah!; uns aventureiros né, as pessoas que gostam de aventura, que gostam de algo novo, diferente.

R: E como vai terminar essa ...., esse passeio.

Pm: Elas vão ficar aí até enjoar e depois vão pra um lugar mais quente né.....

R: Beleza......, acabou? 